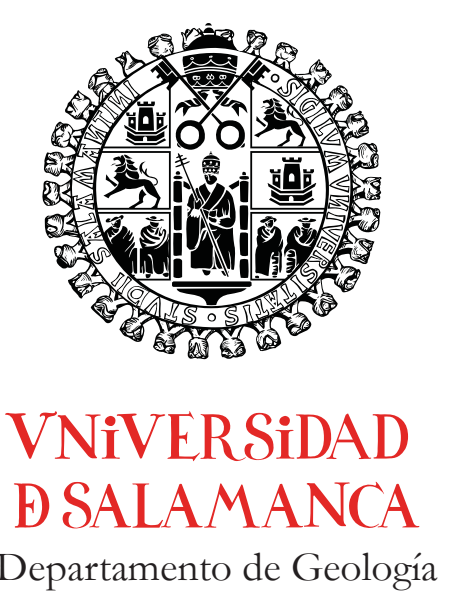

\title{
Evolución paleoceanográfica del Océano Austral (sectores subantárticos del Atlántico y Pacífico) durante el Plioceno tardio-Pleistoceno
}

\author{
Anne-Marie Ballegeer
}

Tesis Doctoral

Salamanca, 2011 



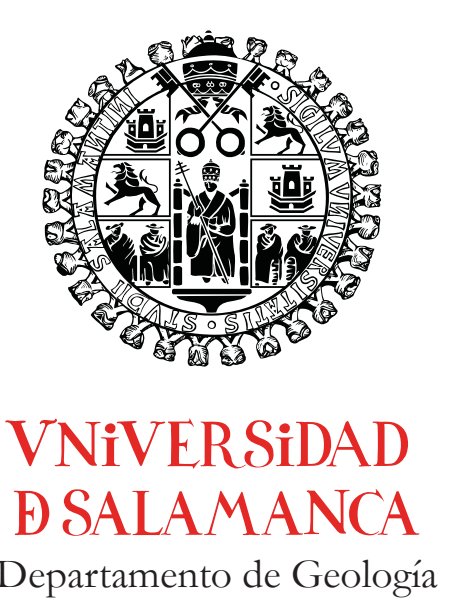

\section{Evolución paleoceanográfica del Océano Austral (sectores subantárticos del Atlántico y Pacífico) durante el Plioceno tardio-Pleistoceno}

Memoria presentada por Anne-Marie Ballegeer para optar al grado de Doctor en Ciencias Geológicas por la Universidad de Salamanca.

Directores de la Tesis:

Dr. José Abel Flores Villarejo

Catedrático del Departamento de Geología (Paleontología)

Facultad de Ciencias

Universidad de Salamanca

Dr. Francisco Javier Sierro Sánchez

Catedrático del Departamento de Geología (Paleontología)

Facultad de Ciencias

Universidad de Salamanca 

Dr. D. José Abel FloresVillarejo y Dr. D. Francisco Javier Sierro Sánchez, profesores del Área de Paleontología en el Departamento de Geología en la Facultad de Ciencias (Universidad de Salamanca)

\section{CERTIFICAN QUE:}

Anne-Marie Ballegeer, ha realizado en el Departamento de Geología en la Universidad de Salamanca y baja nuestra supervisión, el trabajo

"Evolución paleoceanográfica del Océano Austral (sectores subantárticos del Atlántico y Pacífico) durante el Plioceno tardio-Pleistoceno"

Y para que conste, firmamos el presente certificado en Salamanca, Junio de 2011

Los directores:

José Abel Flores Villarejo Francisco Javier Sierro Sánchez

La doctoranda

Anne-Marie Ballegeer 
La realización de esta Tesis ha sido posible gracias a la concesión de la beca BES-2007-14241 de Formación de Personal Investigador (FPI) del Ministerio de Educación y Ciencia (MEC), y la financiación de los proyectos POL2006-10594 y GRACCIE (Programa consolider-ingenio 2010CSD 2007-00067). Adicionalmente se ha obtenido financiación de la Universidad de Salamanca a través del Programa de Difusión de Resultados de la Agencia de Investigación. Agradecemos a el Ocean Drilling Program (ODP) para suministrar las muestras. 




\section{Resumen}

Esta tesis examina el registro de nanofósiles calcáreos de los testigos 1090 (Atlántico Sur) y 1172 (Pacífico Sur) del Ocean Drilling Program (ODP) durante el Plio-Pleistoceno (3.5-1.8 Ma). Los nanofósiles calcáreos (cocolitofóridos) son una excelente herramienta para monitorizar las condiciones de las aguas superficiales del Océano Sur dado que son sensibles a diferentes factores ambientales como la luz, temperatura y concentración de nutrientes. Los registros de nanofósiles han sido comparados con los isótopos bentónicos para reconstruir los cambios paleoceanográficos del Océano Sur durante el intervalo de estudio. Los principales objetivos de este estudio son: (i) caracterizar la asociación de nanofósiles calcáreos del PlioPleistoceno del Océano subantártico, (ii) identificar los cambios en la circulación del Oceáno Sur durante el Plio-Pleistoceno a través del registro de nanofósiles y los isótopos bentónicos y (iii) buscar cambios/ anomalías significantes que podrían estar relacionados con el impacto del asteroide Eltanin en vez de poder explicarse por cambios orbitales.

La fragmentación de los nanofósiles encontrados en los sedimentos ha sido relacionada con disolución y diferentes índices de disolución han sido calculados: (1) DL, basado en la disarticulación de Calcidiscus leptoporus, (2) DP, basado en la fragmentación de Coccolithus pelagicus, (3) NF basado en el número de fragmentos por campo visual y (4) SF basado en el tamaño de los fragmentos. Estos indicadores de disolución confirmen que la señal de nanofósiles no está controlada por la disolución y que la disolución glacial es insignificante.

Las asociaciones de nanofósiles de los testigos ODP 1090 y 1172 han sido interpretadas como características de la zona subantárctica (Subantarctic Zone, SAZ) del Océano Sur, implicando que el Frente Subtropical (Subtropical Front, STF) estaba situado hacia el norte y el Frente Subantárctica (Subantarctic Front, SAF) hacia el sur respecto a los testigos estudiados. Nuestra interpretación está basada en (i) las muy bajas abundancias $(<1 \%)$ de los taxones subtropciales, (ii) las altas abundancias de C. pelagicus, una especie típica de aguas frías, (iii) abundancias de 2-10\% de C. leptoporus, una especie que frecuentemente vive en la zona que está al sur del STF y (iv) las altas abundancias de pequeños Noelaerbabdaceae $(<3 \mu \mathrm{m})$ que en la actualidad dominan la zona hacia el sur del STF. Las variaciones de los nanofósiles calcáreos revelan un patrón glacial-interglacial con altas abundancias de $C$. pelagicus durante los glaciales y de $C$. leptoporus y Helicosphaera carteri durante interglaciales.

Para el testigo ODP 1090 (Atlántico Sur) las tendencias significantes de los nanofósiles han sido analizadas y relacionadas con eventos importantes de la transición climática del Plio-Pleistoceno. Para este testigo se han distinguido cuatro intervalos con diferentes condiciones oceanográficas: Intervalo I (3.14-2.82 Ma) está caracterizado por una alta productividad de cocolitofóridos. Pequeños Noelearbabdaceae dominan la asociación y C.pelagicus tiene abundancias reducidas, lo que ha sido interpretado como un intervalo de altas temperaturas de aguas superficiales (Sea Surface Temperature, SST). Un desplazamiento hacia el sur de los frentes oceánicos ha sido inferido para este periodo, aunque el testigo ODP 1090 permaneció en el SAZ. Intervalo II (2.722.2 Ma) tiene una tasa de acumulación de nanofósiles (Nannofossil Accumulation Rate; NAR) reducida y $C$. pelagicus demuestra un fuerte ascenso de sus abundancias, relacionado con SST's más frías después de 2.72 Ma. Sugerimos que el cierre del canal centro-americano (Central American Seaway, CAS; datado alrededor de $2.74 \mathrm{Ma}$ ) afectó nuestro área de estudio, resultando en SST's más bajos acompañado con un desplazamiento hacia el norte del sistema frontal. El enfriamiento inferido es interrumpido por eventos cálidos cómo es indicado por abundancias mínimas de C. pelagicus entre 2.44 y $2.34 \mathrm{Ma}$, sugiriendo condiciones similares 
a las subtropicales relacionadas con un desplazamiento temporal hacia el sur del sistema frontal. Durante intervalo III (2.2-2-02 Ma) todos los taxones tienen proporciones similares, indicando condiciones estables en la parte superior de la columna de agua. El intervalo entre 2.14 y $2.0 \mathrm{Ma}$, caracterizado por pulsos de las especies cálidas es consistente con un desplazamiento hacia el sur de los frentes oceánicos, aunque el testigo permaneció en la SAZ. Intervalo IV (2.02-1.8 Ma) tiene una asociación de cocolitofóridos similar a la de intervalo I, sugiriendo que la posición de los frentes oceánicas era parecida a la de intervalo I. Los índices de fragmentación de C. pelagicus and C. leptoporus, utilizado para inferir cambios en la circulación profunda del Plioceno tardio, sugieren un incremento de la preservación después 2.2 Ma que ha sido relacionado con una circulación más fuerte de la masa de agua del norte (Northern Component Water) en el Atlántico Sur. La correlación entre los índices de disolución y la dinámica G-IG demuestra que no hay una relación consistente entre ambos parámetros.

Para el testigo ODP 1172 (Pacífico Sur) hemos identificado dos asociaciones diferentes: una asociación de aguas frías (glacial) con porcentajes altos de C. pelagicus y una asociación de aguas cálidas (interglacial) caracterizada con altas abundancias de C. leptoporus y H. carteri. La asociación de aguas cálidas domina antes de 3.1 Ma mientras que el período siguiente está caracterizado por alternancias cortas entre la asociación cálida y fría en concordancia con un enfriamiento global. Alrededor de $2.75 \mathrm{Ma}$, el estadio interglacial G7 se caracteriza por temperaturas especialmente bajas que probablemente están relacionadas con el cierre del CAS, un evento que se cree que ha tenido consecuencias globales. Un incremento gradual de pequeños Reticulofenestra $(<3 \mu \mathrm{m})$ (Very small Reticulofenestra; VSR) a lo largo de nuestra sección marca una tendencia significante dentro del grupo de especies de los pequeños Noelaerhabdaceae y ha sido relacionado con un aumento general de la mezcla de las aguas superficiales, de acuerdo con estudios anteriores. Se ha sugerido que el rápido descenso de pequeños Gephyrocapsa $(<3 \mu \mathrm{m})$ después de estadio isotópico G7 podría estar relacionado con el enfriamiento observado en nuestro testigo después del cierre del CAS.

En el testigo ODP 1090, una abundancia anómalamente alta de VSR ha sido observada alrededor de 2.49 Ma (MIS 99) y ha sido interpretado como un periodo corto de alta concentración de nutrientes y/ó una mezcla más fuerte de la columna superficial de agua. El momento en el que se produce el evento y su corta duración $(9 \mathrm{ka})$, podrían sugerir que la alta concentración de nutrientes en la zona del testigo podría estar relacionado con la proyección de altas cantidades de polvo hacia la atmósfera durante la onda expansivo generado por el impacto del Eltanin. En el testigo ODP 1172, un máximo del NAR total ha sido registrado durante MIS 99. No obstante, este máximo está dentro del rango de fluctuaciones del resto del intervalo. La carencia de evidencias del impacto Eltanin en este testigo puede estar debido a la relativamente baja resolución del registro comparado con el testigo ODP 1090.

Palabras clave: Calcáreos nanofósiles, Océano Sur, Plio-Pleistoceno, paleoceanografía, indicadores de disolución, impacto Eltanin. 


\section{Abstract}

This thesis examines the calcareous nannofossil record of Ocean Drilling Program (ODP) sites 1090 (SouthAtlantic) and 1172 (South-Pacific) for the Plio-Pleistocene (3.5-1.8 Ma) time interval. Calcareous nannofossils (coccolithophores) are an excellent tool to monitor the surface water conditions of the Southern Ocean since they are sensitive to various environmental factors such as light, temperature, nutrient concentration. The records have been compared with the benthic isotope records to reconstruct the paleoceanographic changes of the Southern Ocean during the study interval. The main objectives of this study are: (i) to characterize the Plio-Pleistocene calcareous nannofossil assemblage of the Subantarctic Ocean, (ii) to identify changes in the Plio-Pleistocene Southern ocean circulation through the nannofossil record and (iii) to look for significant changes/anomalies in the record that can be related to the Eltanin impact instead of being explained by orbital variations.

The fragmentation of the coccoliths found in the sediments was related to dissolution and different dissolution proxies were calculated: (1) DL based on the disarticulation of Calcidiscus leptoporus, (2) DP based on the fragmentation Coccolithus pelagicus, (3) NF based on the number of fragments per field of view and (4) $\mathrm{SF}$ based on the size of the fragments. These dissolution proxies confirm that the nannofossil signal is not controlled by dissolution and that glacial dissolution is not significant.

The nannofossil assemblages of ODP sites 1090 and 1172 are interpreted as characteristic for the Subantarctic Zone (SAZ) of the Southern Ocean, implying a northward position of the Subtropical Front (STF) and a southward position of the Subantarctic Front $(\mathrm{SAF})$ with respect to our study sites. This interpretation is based on: (i) the very low abundances $(<1 \%)$ of subtropical taxa, (ii) high abundances of C. pelagicus, a typical cold-water species, (iii) abundances from $2-10 \%$ of $C$. leptoporus, a species that frequently inhabits the zone south of the STF and (iv) the high abundances of small Noelaerhabdaceae $(<3 \mu \mathrm{m})$ which at present dominate the zone south of the STF. The variations of the calcareous nannofossils revealed a glacialinterglacial (G-IG) pattern with high of abundances of C. pelagicus during glacials and of C. leptoporus and Helicosphaera carteri during interglacials.

At ODP site 1090 (South-Atlantic) significant trends in the calcareous nannofossil signal have been analysed and related with important events during the Plio-Pleistocene climate transition. For this site four different intervals with different oceanographic conditions have been distinguished: Interval I (3.14-2.82 Ma) is characterized by high coccolithophore productivity. Small Noelearhabdaceae dominate the assemblage and $C$. pelagicus has reduced abundances, interpreted as being related to higher Sea Surface Temperatures (SST). A southward displacement of the oceanic fronts is inferred for this period, although ODP site 1090 remained in the SAZ. Interval II (2.72-2.2 Ma) has a reduced Nannofossil Accumulation Rate (NAR) and C. pelagicus has a strongly increasing abundance, related to colder SST's after $2.82 \mathrm{Ma}$. We suggest that the closure of the Central American Seaway (CAS) affected our study area, resulting in lower SST's accompanied with a northward movement of the frontal system. The inferred cooling is interrupted by warm events as suggested by minimum C. pelagicus abundances between 2.44 and $2.34 \mathrm{Ma}$, suggesting temporal subtropicallike conditions linked to a temporal southward movement of the frontal system. During Interval III (2.22-02 Ma), all taxa have similar proportions, indicating stable conditions in the upper water column. The interval between 2.14 and $2.0 \mathrm{Ma}$, characterized by pulses of warm species is consistent with a southward movement of the oceanic fronts, with ODP site 1090 remaining in the SAZ. Interval IV (2.02-1.8 Ma) 
has a coccolithophore assemblage similar to interval I, suggesting that the position of the oceanic fronts was similar as during interval I. The fragmentation ratios of C. pelagicus and C. leptoporus, used to infer Late Pliocene deepwater circulation, suggest and increased preservation after 2.2 Ma that has been linked to a stronger Northern Component Water circulation in the South Atlantic. Correlation of the dissolution proxies with G-IG dynamics reveals that there is no consistent relation between both parameters.

At ODP site 1172 (South-Pacific) we have identified two different assemblages: a cold-water (glacial) assemblage with high percentages of $C$. pelagicus and a warm-water (interglacial) assemblage characterized by higher abundances of $C$. leptoporus and $H$. carteri. The warm-water assemblage dominates before $3.1 \mathrm{Ma}$ while the following period is characterized with short alternations of the warm- and cold-water assemblage, in concordance with global cooling trends. Around $2.75 \mathrm{Ma}$, the interglacial stage G7 is characterized by anomalous low temperatures which most likely are linked to definite closure of the CAS, an event that is believed to have had global consequences. A gradual increase of very small Reticulofenestra ( $<3 \mu \mathrm{m}$; VSR) across our section marks a significant trend in the small Noelaerbabdaceae species group and has been linked to a general enhanced mixing of the water column in agreement with previous studies. It is suggested that a rapid decline of small Gephyrocapsa $(<3 \mu \mathrm{m})$ after isotopic stage $\mathrm{G} 7$ might be related to the cooling observed in our study site after the closure of the CAS.

At ODP site 1090, an anomalous high abundance of VSR was observed around 2.49 Ma (MIS 99) and has been interpreted as a short period of higher nutrients concentration and/or more vigorous mixing of the superficial water column. The timing and the short duration $(9 \mathrm{ka})$ of this event, might suggest that the high nutrient concentrations at ODP site 1090 could be linked to the deposition of large quantities of dust during the shock wave generated by the Eltanin impact. At ODP site 1172, a short maximum of the total NAR is registered during MIS 99. Nevertheless, this maximum is within the range of the fluctuations during the rest of the interval. The lack of evidences of the Eltanin impact in ODP site 1172 can be due to the relatively low resolution of the record of ODP site 1172 compared with site 1090.

Keywords: Calcareos nannofossils, Southern Ocean, Plio-Pleistocene, paleoceanography, dissolution proxies, Eltanin impact. 


hora que ha llegado el momento de finalizar esta tesis doctoral me gustaria dar
las gracias a todas las personas que to han hecho posible. En primer lugar me gustaría agradecer a los profesores José-Abel flores Villarejo, María Ángeles Bárcena y Francísco Javier Sierro Sánchez del área de Paleontología porque sin ellos no hubiera podido realizar esta tesis doctoral. A José-Abel porque ha sido mi guía a lo largo de mi investigación, siempre con nuevas inspiraciones e ideas para sacar adelante los resultados y publicaciones cuando yo no lo veía tan claro. A Paco porque, a pesar de estar siempre muy ocupado, ha encontrado tiempo para ayudarme en todas mis dudas. También a Lines, por haberme dado la oportunidad de hacer la tesina y por su esfuerzo en corregir mis textos cuando todavía no conocía bien el lenguaje científico y mucho menos en castellano.

$\mathcal{N}$ o quiero olvidarme de Carlota Escutia que también confío en mi y me ofreció mi primer contrato como "investigadora". También quisiera agradecer a las demás personas que formaron parte del proyecto de mi tesina (Oscar Romero y Renata Lucchi) gracias a los cuales pude contribuir en mi primera publicación.

$\mathcal{A}$ lo largo de esta etapa he tenido la suerte de haber podido trabajar con otros profesores de otras universidades. I would like to thank Hanno Kinkel form the University of Kiel, for the nice stay I had in Germany. Although the Electronic Microscope didn't always work as we wanted, I look back to my stay as a fruitful time. Also to Maria $\mathcal{M}$ arino of the University of Bari because of all the time she spent with me at her desk looking to my data.

Por su puesto todo ha sido más ameno gracias a la buena compañia de los demás becarios del Grupo de Geociencias. Aunque somos tantos que a veces me costaba concentrarme en lo que estaba haciendo, siempre he agradecido la presencia de los demás compañeros. Quiero agradecer a Mariem, Carmen, Deborah, Iván, Montse, Elena, Isma, Gatsby, Bea y Alejandra, los que ya estaban cuando entré y que me acogieron y me ayudaron con las dudas y problemas que tenía al empezar la tesis. También a Diego que no es del GGO pero casi. Y también a Margarita, Eloy y Aleix que aunque llegaron un poquito más tarde siempre han sido Guenos compañeros.

Preparar las muestras nunca me ha parecido muy divertido, pero gracias a José Ignacio ha sido mucho más entretenido de to que podría haber sido. Gracias a él y a la música de radio 3 (música que algún día era más rara que otro) el tiempo en el laboratorio ha pasado más rápido.

Hacer la tesís no sólo es trabajar, y por eso quiero acordarme de toda la gente que he conocido aqui en Salamanca y agradecerles todos los buenos momentos que hemos 
disfrutado. Para empezar quiero mencionar a Andrés, Manu, Alex y Pilar, el núcleo que siempre ha estado presente. Muchas gracias por acogerme en la calle Pastores, ya nos conocemos desde hace unos cuantos años y la verdad que sólo tengo buenos recuerdos con vosotros. También quiero agradecer a toda la demás gente que ha vivido en el piso: a Laura y Blanca por acogerme en el piso; a Dai-linh, la única compañera belga que he tenido en el piso; a Isaac, Gonzalo, Pablo Rigual, Felix, Quique, Pablo (por todos los noodles que hemos comido juntos), Diego, Marek (por la buena compañía y todos los fotos que ha hecho inmortalizando nuestros experiencias de este año) y Valentine (por todas las risas que nos hemos echado durante las fiestas y excursiones que hemos hecho durante el último curso; Portugal forever!). También a Fer y Raquel por todas las fiestas (y partidos de tenis; aunque han sido menos numerosos que las fiestas) que hemos disfrutado. No Quiero olvidarme a Silvia y Salvador por todo su apoyo y hospidalidad aqui en España.

Por último (pero por eso no menos importante) quería mencionar que no podría haber hecho todo ese trabajo sin el apoyo de mi familia en Bélgica, mis padres y mis hermanos que siempre me ha ayudado a pesar de estar lejos de ellos. Y aunque ya te he mencionado antes, gracias Andrés por todo, siempre me to paso bien contigo.

Eindelijk, het zit erop. De thesis is af. Bij deze zou ik graag een aantal mensen willen bedanken die er voor gezorgd hebben dat ik deze taak tot een goed einde heb gebracht. In eerste plaats natuurlijk mijn familie, mama en papa, Koen en Tine, Stefaan en Ilse en Marlies. Vooral aan mama, voor alle steun. Vanaf de eerste dag dat ik de beslissing nam om in Salamanca mijn doctoraat te beginnen. Het is altijd enorm fijn geweest om thuis te komen en van jullie gezelschap te kunnen genieten en te horen wat er allemaal gebeurt is in de tijd dat ik er niet was.

Ik zou ook nog mijn vrienden en kenissen uit België willen Gedanken, omdat zij mij altjid vroegen hoe het hier ging en me op de hoogte hielden van hun avonturen in België. Vooral aan Vick, Katrijn, Nina, Robin en Annelies die me altijd met open armen hebben ontvangen tijdens mijn bezoekjes aan Gent!

\section{Gracias a todos! Espero no olvidarme a nadie}






\section{Contents}

\section{Aims and structure of the thesis}

I. General Framework

II. Objectives

III. Structure of the thesis

\section{CHAPTER 1: INTRODUCTION}

1.1. Global climate variability

1.2. Plio-Pleistocene climate trends

1.2.1. The Mid Pliocene Warmth 6

1.2.2. First climate reorganization $\sim 2.75 \mathrm{Ma}$ 9

1.2.3. Second climate reorganization $\sim 2.2 \mathrm{Ma}$

1.3. The Eltanin impact $\quad 12$

CHAPTER 2: OCEANOGRAPHIC SETTINGS

2.1. The Southern Ocean $\quad 17$

2.2. The South Atlantic 18

2.3. The Tasman Sea 20

CHAPTER 3: MATERIAL AND METHODS

3.1. Material 25

3.1.1. ODP site $1090 \quad 25$

3.1.2. ODP site 1172

3.2. Methods

$\begin{array}{ll}\text { 3.2.1. Sample preparation } & 27\end{array}$

3.2.2. Counting techniques 28

3.2.3. Stable isotope measurements 28

\section{CHAPTER 4: COCCOLITHOPHORES}

4.1. Introduction $\quad 33$

4.1.1. General characteristics 33

4.1.2. Life cycle 34

4.1.3. Coccolithophore distribution $\quad 35$

4.2. Sedimentation and preservation in the sediments 35

4.2.1. Sedimentation $\quad 35$

4.2.2. Dissolution 36

4.3. Coccolithophore taxonomy and ecological affinities 37

4.3.1. Coccolithus pelagicus 38

4.3.2. Calcidiscus leptoporus 38

4.3.3. Reticulofenestra 39

4.3.4. Gephyrocapsa 40

4.3.5. Helicosphare carteri 40

4.3.6. Helicosphaera sellii 41

4.3.7. Subtropical taxa 41 
5.1. ODP site 1090

5.2. ODP site 1172

5.2.1. Nannofossil biostratigraphy 46

5.2.2. Magnetostratigraphy 50

$\begin{array}{ll}\text { 5.2.3. Oxygen isotope stratigraphy } & 50\end{array}$

CHAPTER 6: CARBONATE DISSOLUTION IN ODP SITE 1090

COMPARISON OF DIFFERENT DISSOLUTION PROXIES

6.1. Introduction $\quad 55$

6.2. Different methods 56

6.2.1. Number and size of fragments 56

6.2.2. Fragmentation ratio based on single species 56

6.3. Comparison and evaluation of the different proxies 58

6.4. Conclusions 60

CHAPTER 7: COCCOLITHOPHORE DISSOLUTION VERSUS PRODUCTIVITY

CHANGES DURING THE PLIO-PLEISTOCENE (3.14-1.80 Ma) IN THE

SOUTH ATLANTIC (ODP SITE 1090)

Abstract

7.1. Introduction

7.2. Regional setting

7.3. Material and methods 66

7.3.1. Material 06

7.3.2. Sample preparation and counting technique 66

$\begin{array}{ll}\text { 7.3.3. Preservation and dissolution proxies } & 67\end{array}$

$\begin{array}{ll}\text { 7.3.4. Age model } & 67\end{array}$

$\begin{array}{ll}\text { 7.3.5. Taxonomy } & 68\end{array}$

$\begin{array}{ll}\text { 7.4. Results } & 68\end{array}$

$\begin{array}{lr}\text { 7.5. Discussion } & 71\end{array}$

$\begin{array}{ll}\text { 7.5.1. Paleoproductivity } & 71\end{array}$

$\begin{array}{ll}\text { 7.5.2. Carbonate dissolution trends } & 75\end{array}$

$\begin{array}{ll}\text { 7.5.3. The Eltanin impact } & 75\end{array}$

$\begin{array}{ll}\text { 7.6. Conclusions } & 76\end{array}$

CHAPTER 8: MONITORING FLUCTUATIONS OF THE SUBTROPICAL FRONT IN THE TASMAN SEA BETWEEN 3.45 AND 2.45 Ma (ODP SITE 1172)

Abstract

8.1. Introduction

8.2. Regional setting

8.3. Material and methods 83

$\begin{array}{lr}\text { 8.3.1. Material } & 83\end{array}$

8.3.2. Methods $\quad 83$

$\begin{array}{ll}\text { 8.4. Age Model } & 85\end{array}$ 
8.4.1. Magnetostratigraphy $\quad 85$

8.4.2. Oxgen isotope stratigraphy 85

8.5. Preservation and dissolution index $\quad 87$

8.6. Results and discussion $\quad 87$

8.6.1. Calcareous nannofossil assemblages and abundances 87

8.6.2. Nannoplankton assemblages between 3.45 and $2.45 \mathrm{Ma} \quad 87$

8.6.3. Glacial-interglacial variability 89

8.6.4. Isotopic stage G7 91

8.6.5. Trends in small Noelaerbabdaceae $\quad 92$

8.7. Conclusions 92

CHAPTER 9: SYNTHESIS (COMPARISON OF THE ATLANTIC AND THE PACIFIC RECORD)

9.1. Paleoposition of the Subtropical Front 95

9.2. Glacial-interglacial variability 99

9.3. Plio-Pleistocene climate transition $\quad 101$

9.4. The Eltanin impact 102

9.5. Small Noelaerhabdaceae 103

$\begin{array}{lr}\text { CHAPTER 10: CONCLUSIONES } & 109\end{array}$

REFERENCES 115

$\begin{array}{lr}\text { APPENDIX } & 129\end{array}$ 



\section{AIMS AND STRUCTURE OF THE THESIS}

\section{General Framework}

This work forms part of the third International Polar Year, an international initiative that focuses on Arctic and Antarctic Research. Climatic research indicates that the polar regions play an important role in driving and amplifying the global climate variability, an excellent example is the distinct warming of the Arctic region seen today. A better understanding of the interaction between the polar regions and the global climate are of great interest, especially given the global warming observed today. The last predictions published by the International Intergovernamental Panel on Climate Change (IPCC) suggest a global temperature increase of $2-3^{\circ} \mathrm{C}$ by the end of this century. In this context, scientists have suggested that studying the climate of the past can provide valuable information on the working of the global climate. The research team of the University of Salamanca (GGO-Grupo de geociencias océanicas) has focused on the paleoceanography of the Southern Ocean through the study of several microplankton groups in several national and international projects. This work forms part of an international project between the Universidad de Salamanca and the Alfred Wegener Institut that focuses on the paleoceanographic changes registered in the Southern Ocean during the Plio-Pleistocene (3.5-1.8 Ma). Special attention is given to the interval of the Eltanin asteroid impact which took place around 2.5 Ma in the Bellinghausen Sea (Southern Ocean) and its possible consequences on the ocean circulation or global climate.

\section{Objectives.}

The main objectives of this thesis were:

- To characterize the Plio-Pleistocene calcareous nannofossil assemblage of the Subantarctic Ocean.

- To identify changes in the Plio-Pleistocene Southern Ocean circulation through the nannofossil record.

- To look for significant changes/anomalies in the record that can be related to the Eltanin impact instead of being explained by orbital variations.

Additionally some more specific goals have been addressed during this work:

- To exclude dissolution as the main factor controlling our nannofossil record and to validate the number nannofossils accumulated in the sediment as an indicator for the surface coccolithophore productivity.

- To infer high-resolution changes in deep-water circulation through different dissolution proxies.

- To monitorize latitudinal movements of the oceanic fronts based on the observed variations of the calcareous nannofossil assemblages.

- To reconstruct the coccolithophore paleoproductivity, at supra-orbital and orbital scale .

- To improve the knowledge on the ecological affinities of the Plio-Pleistocene calcareous nannofossil taxa. 


\section{Structure of the thesis}

\section{Part one: Introduction (Chapters 1-4).}

The first chapters of this thesis serve as an introduction to the research topic. Chapter 1 gives a resumed overview on the current knowledge about the Plio-Pleistocene climate transition which is of interest for a better understanding of the results obtained during this work. Chapter 2 resumes the oceanographic and atmospheric setting of the study area. The next chapter, chapter 3, gives an extended summary of the studied material and the different techniques used to obtain our results. In Chapter 4, the general characteristics of coccolithophores (the microplankton group used in this study) considered significant for our work are briefly discussed.

Part two: results and discussion (Chapters 5-9).

In chapter 5 the age model of both cores (ODP site 1090 and ODP site 1172) is exposed. Chapter 6 focuses on the carbonate dissolution of ODP site 1090 (South-Atlantic). In this chapter the different dissolution indexes that were calculated are presented and discussed. Chapters 7 and 8 are manuscripts that are submitted (or ready to be submitted) to international scientific journals.

Chapter 7: Coccolithophore dissolution versus productivity changes during Plio-Pleistocene (3.14 - $1.80 \mathrm{Ma})$ in the South Atlantic (ODP site 1090).

Ballegeer, A.M, Flores, J.A., Sierro, F.J and Gersonde, R.

To be submitted to Marine Micropaleontology

Chapter 8: Monitoring fluctuations of the Subtropical Front in the Tasman Sea between 3.45 and $2.45 \mathrm{Ma}$ (ODP site 1172).

Ballegeer, A.M., Flores, J.A., Sierro, F.J. and Anderssen, N.

Submitted to Palaeogeography, Palaeoclimatology, Palaeoecology

In chapter 9, a general synthesis was made comparing the results of the two previous chapters.

\section{Part three: Conclusions (Chapter 10).}

The final Chapter presents the conclusions that were drawn at the end of this thesis. 


\section{CHAPTER 1: INTRODUCTION}

1.1. Global climate variability

1.2. Plio-Pleistocene climate trends

1.2.1. The Mid Pliocene Warmth

1.2.2. The first climate reorganization $\sim 2.75 \mathrm{Ma}$

1.2.3. The second climate reorganization $\sim 2.2 \mathrm{Ma}$

1.3. The Etanin impact 



\section{CHAPTER 1: INTRODUCTION}

\subsection{Global climate variability}

In its fourth assessment report, the Intergovernmental Panel on Climate Change (IPCC) has highlighted its concern about recent developments, such as increased $\mathrm{CO}_{2}$ levels coupled with shrinking ice sheets and global warming, that affect our current climate (IPCC, 2007). A better understanding of the past climate distribution is a key for understanding the global climate and can aid prediction of future climate changes. In this context, the Mid Pliocene Warmth interval, around $\sim 3 \mathrm{Ma}$ ago, is an excellent study example since it is the most recent interval of geological time when global temperatures were substantially warmer $\left(2-3^{\circ} \mathrm{C}\right)$ for a sustained period (Crowley, 1996). During the Mid-Pliocene, the land-sea configuration and continental position were the same as at present and the basic patterns and of ocean circulation and faunal and floral distributions were similar. Moreover, many Mid-Pliocene species are extant, facilitating the calibration of the different paleo-proxies. Despite these similarities, orbital forcing during the Pliocene was not the same as today and the Mid-Pliocene is part of a long term cooling trend which is not the case for the present. However, we consider that the Plio/Pleistocene time interval holds valuable information for modeling the present and the future climate.

\subsection{Plio-Pleistocene climate trends}

Following the recent calibration, the Pliocene Epoch spans a time frame from ca. 5.3 to 2.58 Ma ago and the Pleistocene from 2.58 to 0.012 Ma ago (Gibbard et al., 2010). Our study record ranges between 3.5 and $1.8 \mathrm{Ma}$, covering the Late Pliocene and the Early Pleistocene. The Plio-Pleistocene in its totality is part of a general cooling trend that started around $34 \mathrm{Ma}$ with the first glaciations at the Antarctic continent (DeConto and Pollard, 2003) (Fig. 1.1). The overall global cooling is related to a combination of: (i) declining atmospheric $\mathrm{CO}_{2}$ concentrations (Pearson and Palmer, 2000), (ii) changes in the earth's orbits (Haug and Tiedemann, 1998; Maslin, 1998), (iii) tectonic movements such as the closure of the Central American Seaway (CAS) and the uplift of important mountain chains (Hay et al., 2002).

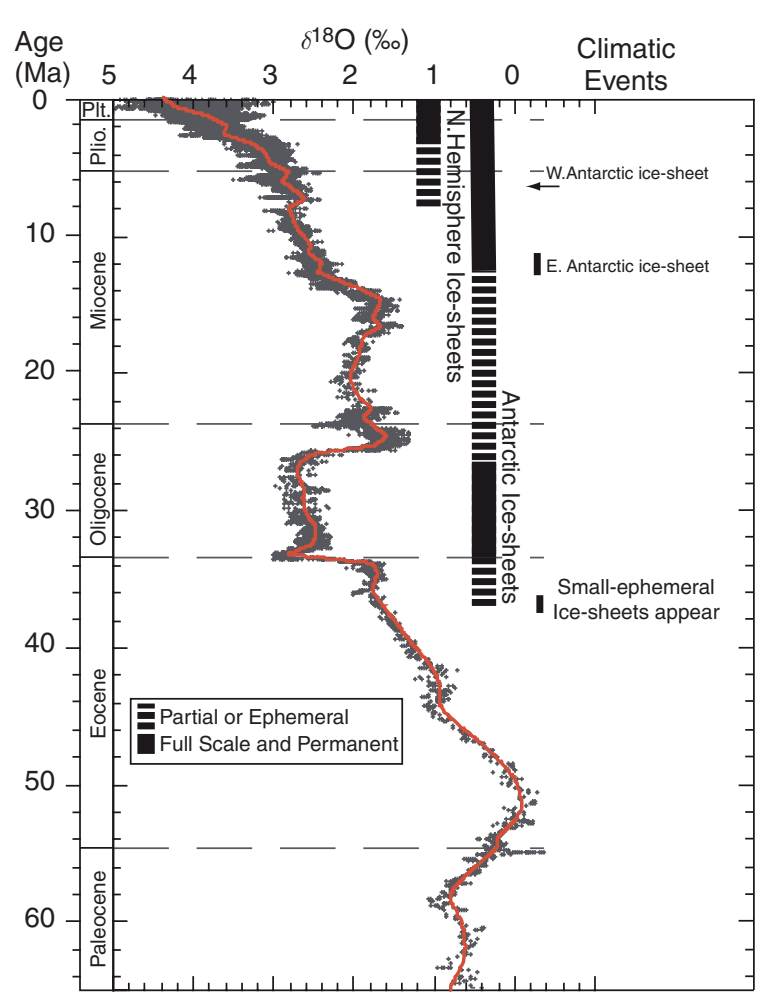

Fig. 1.1. Composite global oxygen isotope record compiled from measurements of benthic $\delta^{18} \mathrm{O}$. The red line represents an adjusted five-point running mean. Highly generalized occurrence of polar ice-sheets is indicated by black bars. Black vertical bars show the occurrence of east and west Antarctic ice sheets and Northern Hemisphere ice sheets. Small and ephemeral ice sheets may have developed in the Northern Hemisphere as early as the late Miocene but permanent ice sheets did not develop until the middle of the Pliocene. Modified from Poore (2007). 
Climatically, the Pliocene can be divided in three phases, (i) an Early Pliocene warm period, (ii) a short interval around ca. $3 \mathrm{Ma}$ that has been referred to as the Mid Pliocene Warmth (MPW), and (iii) a climatic deterioration leading to the high-magnitude climate variability recorded in the Pleistocene (Haywood et al., 2009) (Fig. 1.2). In the following paragraphs, the most important aspects of the Plio-Pleistocene climate trends will be discussed.
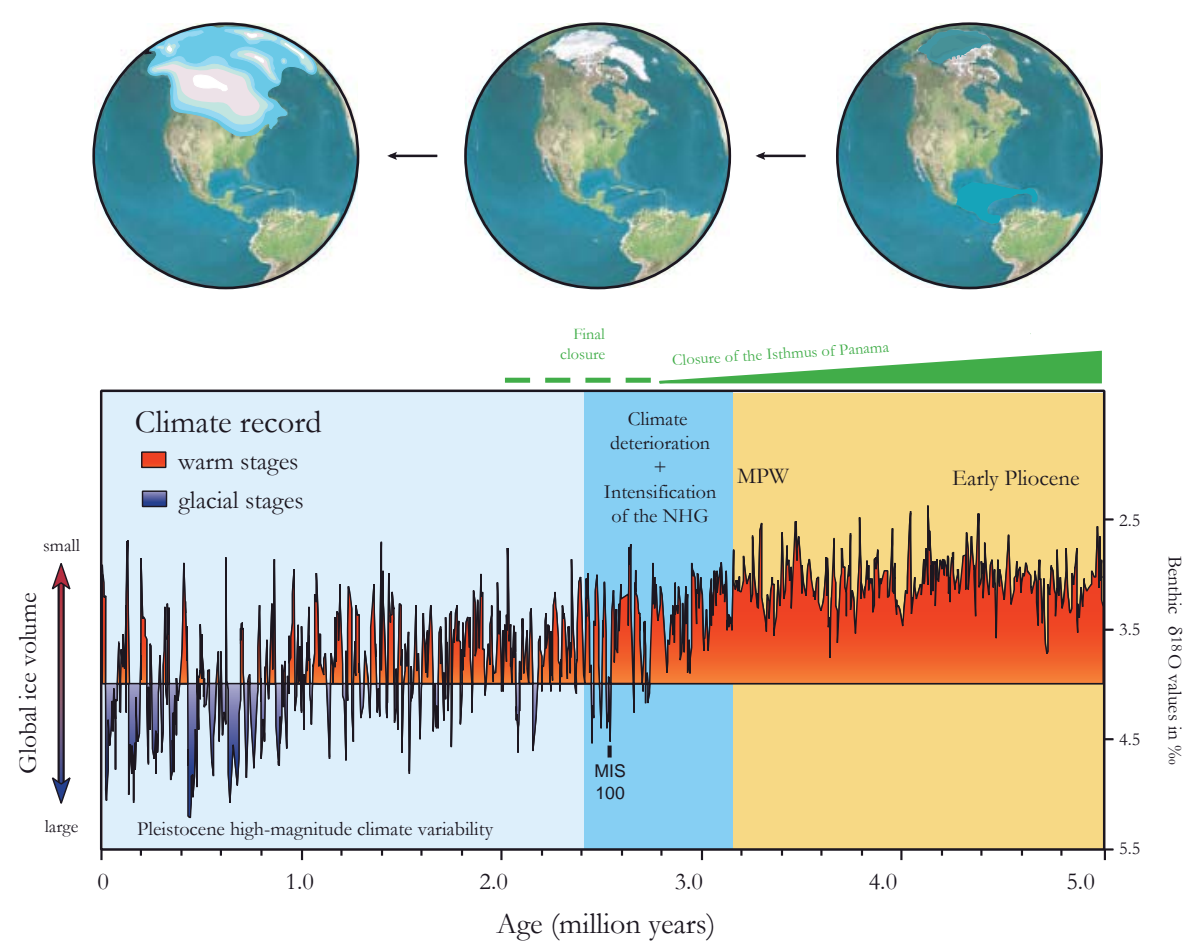

Paleoceanographic reconstruction for the last $5 \mathrm{Ma}$.

Fig. 1.2. Climate record of the last $5 \mathrm{Ma}$ as indicated by benthic $\delta^{18} \mathrm{O}$ isotope values (Tiedemann et al., 1994), with indication of the important events of this time period. Modified from Steph (2006).

\subsubsection{The Mid Pliocene Warmth (MPW)}

During the last decades numerous scientist have focused on the MPW, resulting in the release of digital $2^{\circ} \times 2^{\circ}$ dataset providing information on global Mid-Pliocene sea surface temperatures (SST's) (Fig. 1.3), Atlantic/ Pacific Ocean bottom water temperatures, vegetation cover, terrestrial and sea ice cover, sea levels and topography (Dowsett et al., 2010). Some aspects of the MPW are uniformly recognized while some others remain controversial. There is a general consensus that the MPW was characterized by higher temperatures (2-3 ${ }^{\circ} \mathrm{C}$, Sloan et al., 1996), higher $\mathrm{CO}_{2}$ levels (up to $425 \mathrm{ppm}$; Raymo et al., 1996), and higher sea levels (up to $25 \mathrm{~m}$; Dowsett, 2007; Dwyer and Chandler, 2009; Miller et al., 2005). Terrestrial and marine paleoclimate proxies revealed that higher temperatures were not globally uniform, the tropics had temperatures similar to the present and warming increased towards the poles resulting in a weak equator to pole gradient (Dowsett et al., 1996; Thompson, 1991; Thompson and Fleming, 1996). Despite the large number of evidences that support the Pliocene's warm climate, the reasons for this warmth remain unsolved. Several theories have been suggested: (A) An altered atmospheric trace gas concentrations and water vapour content, (B) Changes in meridional heat transport, (C) Permanent El Niño-conditions and (C) Ice-Albedo Feedbacks. 

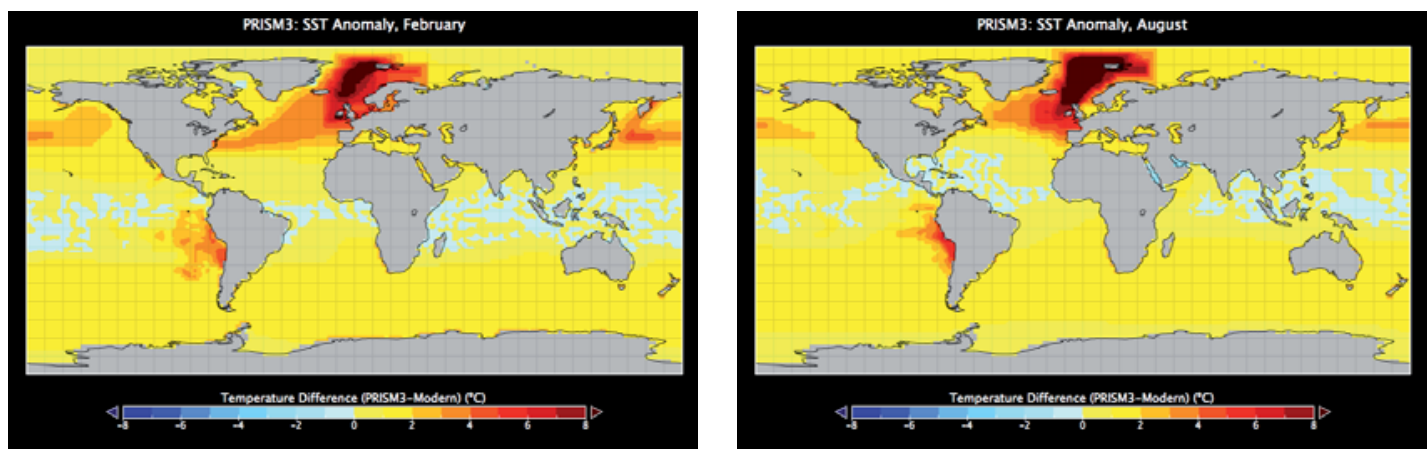

Fig. 1.3. Pliocene sea surface temperature maps derived from the PRISM3_SST_v1.0 dataset. The colors highlight the temperature difference between modern and the Pliocene SST (Dowsett et al., 2010)

\section{A. Altered atmospheric trace gas concentration and water vapour content.}

Measurements of $\delta^{13} \mathrm{C}$ of marine organic preserved matter in the deep-sea sediments (Raymo et al., 1996; Raymo and Rau, 1992) and the stomal density of fossil leaves (Kürschner et al., 1996; Van Der Burgh et al., 1993) indicate that the Pliocene atmospheric $\mathrm{pCO}_{2}$ levels were up to $450 \mathrm{ppm}, 35 \%$ higher that the preindustrial level and slightly higher than today. These authors suggest that the higher $\mathrm{CO}_{2}$ concentrations may be responsible, or at least partly, for the MPW. This hypothesis explains the warmth of the Pliocene at a global scale but is not able to explain heterogeneous warming as is suggested by paleoclimatic proxies (Crowley, 1996).

\section{B. Changes in meridional heat transport}

SST estimates from diatom and planktonic foraminiferal assemblages showed significant warming at higher latitudes (especially in the North Atlantic and the Pacific Ocean), but no warming in the tropics (Dowsett, 1999; Dowsett et al., 2009; Dowsett and Robinson, 2009). This may be a result of enhanced meridional ocean heat transport, caused by a stronger North Atlantic Deep Water (NADW) formation and enhanced thermohaline circulation (THC) (Billups et al., 1997; Dowsett et al., 1996; Dowsett et al., 1992; Raymo et al., 1996). Important weaknesses in the hypothesis that an enhanced THC was responsible for the MPW are: (1) the THC argument can't be ascribed to all ocean basins and (2) this argument can't generate the correct reconstructed hemispheric temperature distribution (Crowley, 1996). Kim and Crowley (2000), on the other hand, claim that enhanced THC can also be a consequence of the MPW. These authors suggest that increased temperature and $\mathrm{CO}_{2}$ levels caused melting of the Antarctic ice sheets, introducing fresh water into the ocean and thereby reducing the Antarctic Bottom Water outflow (AABW). This reduced AABW outflow allowed greater NADW production in the North and thus an enhanced THC. On the contrary, general circulation models (GCM) published by Haywood \& Valdes (2004) indicate that neither the oceans nor the atmosphere transported significantly more heat during the MPW.

\section{Permanent E1 Niño-conditions}

One of the most exciting recent developments in Pliocene research has been the examination of tropical climate dynamics and tropical high-latitude climate linkages. Recent multi-proxy studies of equatorial Pacific SST's show that the East-West gradient was greatly reduced during the Mid-Pliocene due to undeniable 
warming of the Eastern Equatorial Pacific (EEP) and relative stability of the West Pacific warm pool (WPWP) (Dowsett and Robinson, 2009; Ravelo et al., 2006; Wara et al., 2005). This situation is akin to an El-Niño event as described for the last $1.5 \mathrm{Ma}$ (Fig. 1.4). During an El Niño event the trade winds along the Equator, and hence the Walker Circulation, collapses. Additionally, a diminution of the low-level stratus clouds in the tropics and an increase of the water vapour are observed, leading to a general global warming (Barreiro et al., 2006) (Fig. 1.4). The interpretation of a permanent El Niño state remains controversial given the fact that the temporal resolution of most of the paleoceanographic is too large to detect El Niño Southern Oscilation (ENSO) which occurs over a decadal to sub-decadal time scale. An apparent El Niño pattern in the record can be explained by other changes in the Earth system, making it impossible to support El Niño as unique solution that explains the MPW. Despite this uncertainties, a recent study has indicated that our current state of knowledge doesn't allow us to rule out the possibility of a permanent El Niño state during the Mid Pliocene, and further investigation is needed (Bonham et al., 2009).
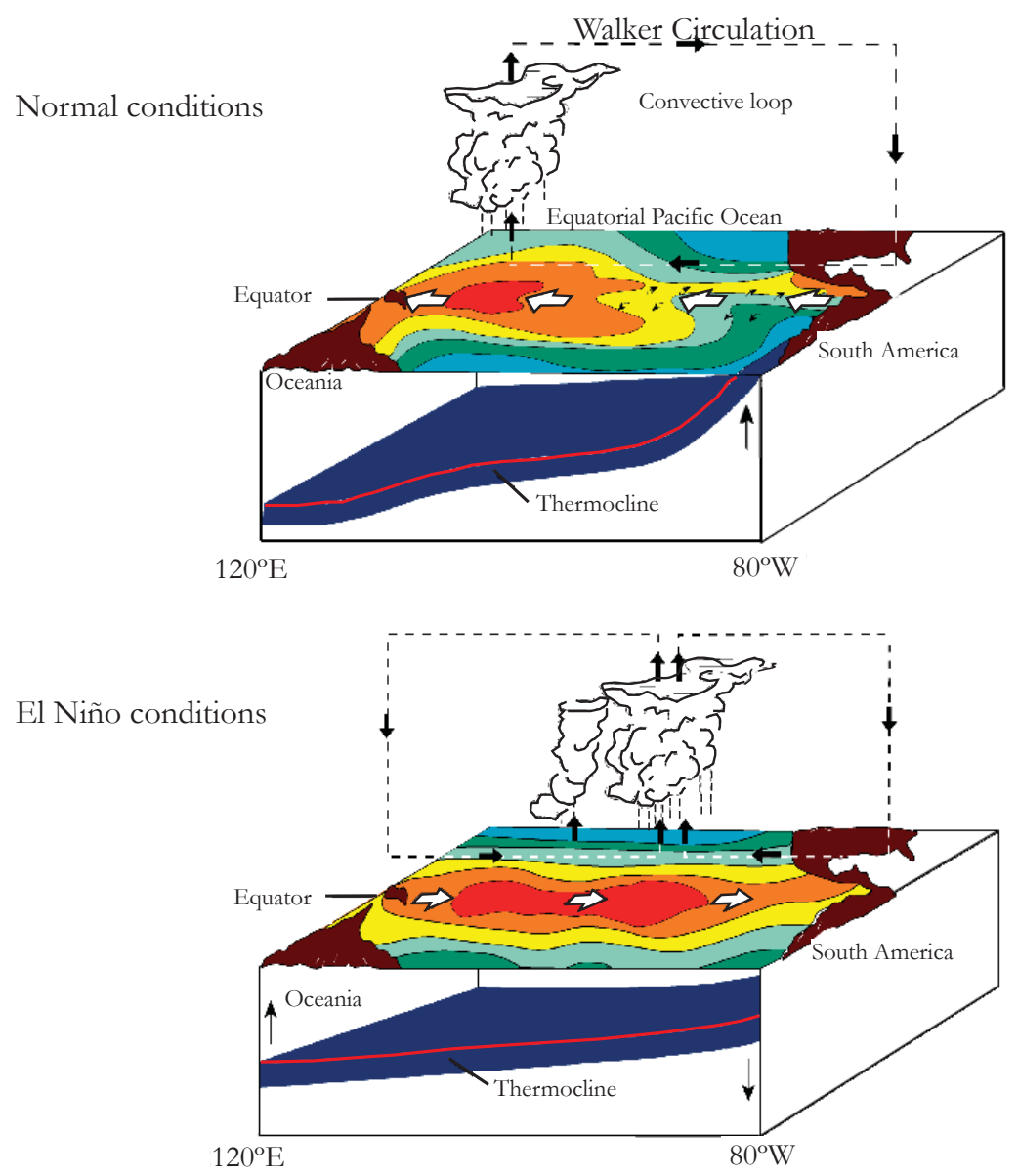

Fig. 1.4. Sea surface temperature oscillation in the tropical Pacific. During normal conditions, trade winds carry warm water towards the West-Equatorial Pacific. During El Niño conditions, the trade winds collaps resulting in a general warming of the Equatorial Pacific. Modified from http://www.pmel.noaa.gov/tao/ proj_over/diagrams/index.html.

\section{Ice-Albedo feedback}

Various authors underline the importance of ice-sheet albedo feedbacks in the global warming observed during the MPW (Haywood and Valdes, 2004; Salzmann et al., 2009). A decreased extent of the Antarctic ice sheet during the Pliocene is supported by $\delta^{18} \mathrm{O}$ records (Lisiecki and Raymo, 2005), ice sheet modeling (Hill et al., 2007) and microfossil data (Whitehead et al., 2004). However, the discussion whether or not the Antarctic remained fully glaciated or underwent a significant reduction continues (Wise, 2000 and references 
therein). If the hypothesis of a reduced ice sheet is correct, this would have caused lower albedo and consequent greater absorption of radiation and thus enhanced warming, leading to more ice melting. This feedback mechanism, together with other factors, could have been responsible for the sustained warm climate between 3.3 and 3.0 Ma.

It is clear that the complexity of the Earth system, and the strong interaction between different processes makes it difficult to develop a solid explanation for the MPW. We can conclude that all of the previous stated explanations most likely were connected between one another, together with other unknown processes/ feedback mechanisms, resulting in a sustained warm climate during the Mid-Pliocene.

\subsubsection{First climate reorganization $\sim 2.75 \mathrm{Ma}$}

After the MPW, a first climate reorganization is registered at high latitudes and in the sub-tropics and has been related to the Northern Hemisphere Glaciation (NHG). Ice started to accumulate at the North Pole between 10 and $6 \mathrm{Ma}$ ago but was highly intensified around 2.75 Ma (Maslin et al., 1996; Wolf and Thiede, 1991). Lot of attention has been drawn to the onset of the NHG and what may be the ultimate cause of this. Most scientist agree that cooling is associated with decreasing atmospheric $\mathrm{CO}_{2}$ levels and that the development of a solid ice sheet requires (i) moisture arriving to high latitudes allowing snowfall and (ii) cool summers that prevent snow from melting so that the ice sheet can keep growing (Milankovitch, 1941). Although some scientists try to ascribe the cooling to one single mechanism or event, it has to be seen as a gradual process influenced by different regional processes at distant locations and at different times. Three important regional processes that influenced the NHG are: (A) the closure of the CAS, (B) the closure of the Indonesian Gateway and (C) the Subantarctic Pacific.

\section{A. Closure of the Central American Seaway (CAS)}

The closure of the CAS is a result of the subduction of the Pacific Cocos and Nazca plates underneath the North and South American Plate and later the Caribbean plate (Meschede and Frisch, 1998; Meschede et al., 1999). The uplift history of the CAS starts in the Miocene when benthic foraminiferal fauna indicates that the intermediate water connection between the Pacific and Caribbean was broken (Coates, 2004; DuqueCaro, 1990). Between 12 and $6 \mathrm{Ma}$, the CAS shoaled up to $200 \mathrm{~m}$ (Duque-Caro, 1990) although some deeper incisions (500-200 m) still existed (Collins, 1996). Evidences of exchange of terrestrial fauna are found between 9 and $8.3 \mathrm{Ma}$, indicating that an extended archipelago existed around that time (Marshall et al., 1982; Webb, 1985). Shoaling of the CAS continued and reached a critical threshold from 4.6-4.2 Ma, when it started to affect the exchange of the upper ocean water masses as suggested by the $\delta^{18} \mathrm{O}$ values of planktonic foraminifera that indicate a salinity increase in the Caribbean (Haug et al., 2001). At this point profound reorganization of surface circulation started in different areas (Haug and Tiedemann, 1998). The "great American interchange" of vertebrates that is supposed to require a land bridge between the Americas occurred at about 3-2.7 Ma (Marshall et al., 1982), marking the final step in the closure of the CAS (Lundelius, 1987; Marshall, 1988; Marshall et al., 1982). The final closure of the CAS changed the freshwater balance of the tropical Pacific and the Caribbean sea: higher precipitations in the Pacific and more evaporation in the Caribbean sea led to a salinity increase of the Caribbean sea (Haug et al., 2001). This salinity increase is coupled with an intensification of the THC and an increased Gulf Stream transports warm and saltier 
water to the North-Atlantic (Fig. 1.5). An enhanced heat transport to the poles is also inferred by ostracodes, planktic foraminiferal assemblages (Dowsett et al., 1992) and GCM's (Schneider and Schmittner, 2006). Scientists believe that the enhanced THC supplied more moisture to the high latitude and hence favored the onset of the NHG. Other important changes in the oceanic and atmospheric circulation, caused by the final closure of the CAS, are: (i) In the tropical east-Pacific, the locus of maximum opal accumulation shifted eastwards due to reorganization of the surface ocean circulation (Farrell et al., 1995) and (ii) a southward shift of the ITCZ is inferred from planktonic foraminiferal oxygen isotope records from the Western and Eastern tropical Pacific and Atlantic Oceans (Billups et al., 1999).
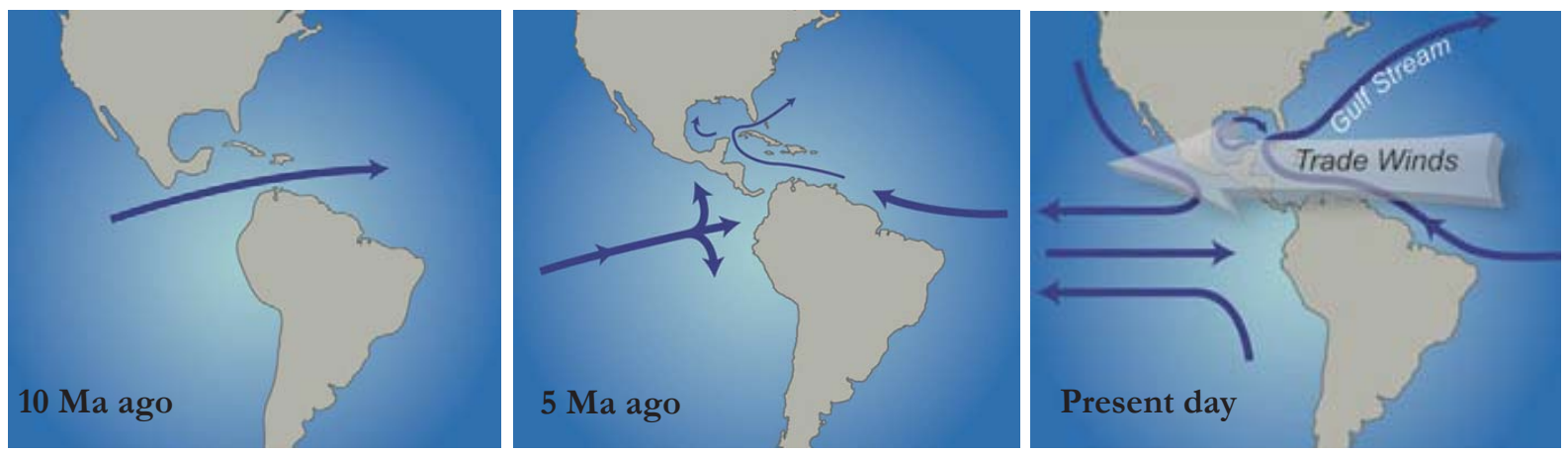

Fig. 1.5. Gradual closure of the CAS. Before the closure of the CAS, surface waters flowed from the Pacific into the Atlantic (around $10 \mathrm{Ma}$ ago). About $5 \mathrm{Ma}$, the gradual closure of the CAS restricted water exchange between the Atlantic and the Pacific. After the definite closure, the Gulf Stream intensified, transporting salty and dense waters to the Arctic. Trade Winds carry the water vapor westward across the low-lying isthmus, depositing fresh water into the Pacific through rainfall. As a result, the Atlantic is saltier than the Pacific. Modified from Haug et al. (2004).

\section{B. Closure of the Indonesian gateway}

Relatively less attention has been paid to the narrowing of the Indonesian Gateway, but some studies underline the possible role of the tropical Pacific in the late Pliocene global climate change (Cane, 1998; Cane and Molnar, 2001). The narrowing of the Indonesian gateway is caused by the northward movement of Australia and New Guinea(Fig. 1.6). At 5-3 Ma, Australia and New Guinea lay 2-3 ${ }^{\circ}$ South of their present positions and the Halmahera was a smaller island (DeMets et al., 1994) (Fig. 1.6). A wide gap between New Guinea and Halmahera could be interpreted as a seaway between the Pacific and the Indian Ocean as wide and deep as the Makassar Strait. Before $\pm 5 \mathrm{Ma}$, warm water from the South Pacific would have passed into the Indian Ocean, increasing the SST's in the Indian Ocean and leading to a rainier climate in Eastern Africa (Cane and Molnar, 2001). As New Guinea-Australia continued moving northward, the colder waters from the north replaced the warmer southern water in the Indonesian throughflow, cooling the thermocline in the Indian Ocean (Fig. 1.6). Hydrographic measurements show that almost all water currently passing through the Indonesian seaway derives from the North Pacific Ocean (Gordon and Fine, 1996; Gordon et al., 1999). Warm southern Pacific water currently moves westward along the Equator, in the Southern Equatorial Current (SEC), along the north coast of New Guinea to the Halmahera Eddy, just east of the island of Halmahera, where it turns to flow eastward in the North Equatorial Countercurrent (NECC) (Fig. 1.6). This redistribution of the ocean currents most likely has caused drying of Africa since a cooler Indian Ocean reduces the rainfall in East Africa (Goddard and Graham, 1999; Hastenrath et al., 1993; Reverdin et al., 1986). Cane \& Molnar (2001)suggest, although speculative, that these changes in the circulation of the tropical Pacific, caused by the narrowing of the Indonesian gateway, may have played a role in the onset NHG. They argument that the absence of an abrupt change in the $\delta^{18} \mathrm{O}$ record indicates that a relatively 
slow geologic process affecting high latitude climate gradually, not abruptly, may have forced the initiation of the NHG. They claim that the closure of the Indonesian seaway provides such a gradual change at the right time (Cane and Molnar, 2001).
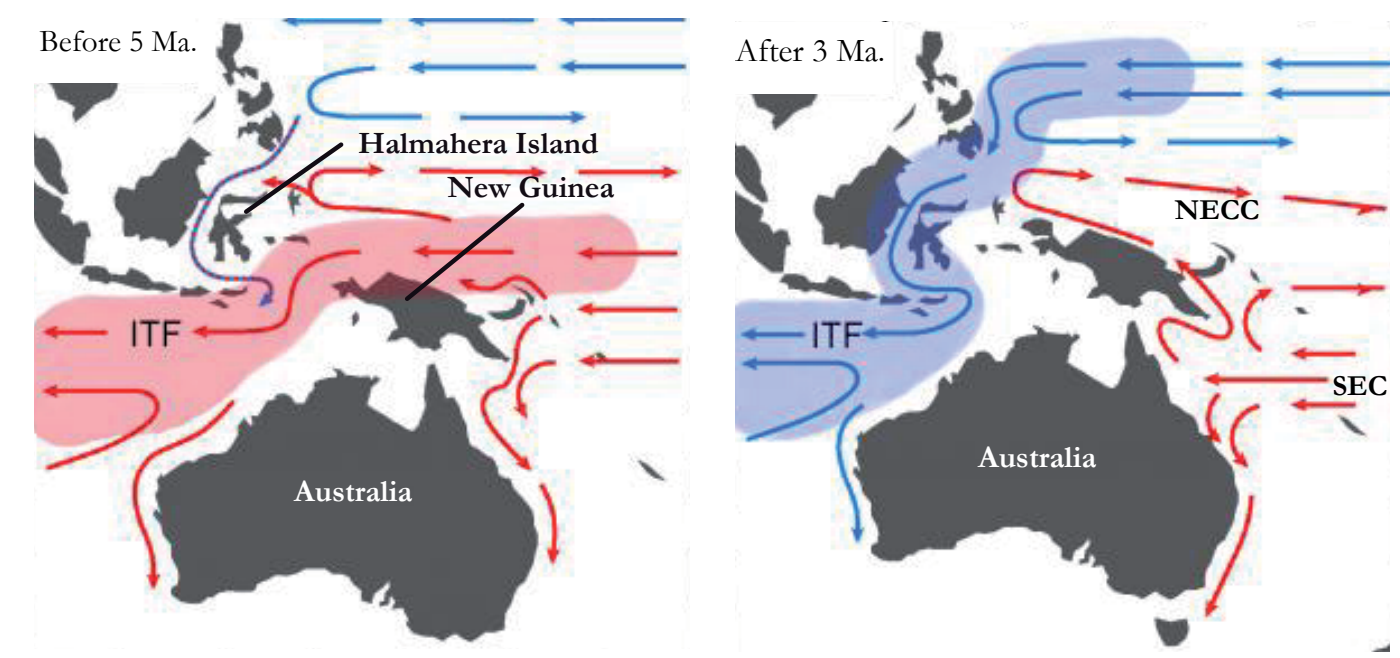

Fig. 1.6. Changes of the surface circulation after closure of the Indonesian gateway. The $5 \mathrm{Ma}$ scenario is based on general circulation models. Note that the source of water masses entering the Indian Ocean changed considerably: The water that passes through the Indonesian seaway derived from the South-Pacific before $5 \mathrm{Ma}$ and from the North Pacific after closure of the Indonesian gateway (Leibniz Institute of Marine Sciences, 2009).

\section{Subarctic Pacific}

A recent study claims that the subarctic Pacific Ocean played an important role in the start of the NHG because it represents a significant source of water vapor to boreal North America which is an important region of snow accumulation (Haug et al., 2005). Diatom oxygen isotopes ratios and the alkenone unsaturation ratios indicate an important change in the subarctic Pacific during glacial stage G6 (ca. 2.7 Ma ago) which is believed to be triggered by an obliquity minimum. The data suggest an enhanced seasonality that has been linked to the establishment of a permanent halocline at that time. The heat capacity of sea water causes surface waters to remain warm into the autumn and cool into the spring. Stratification will decrease this thermal capacity of the upper ocean, reducing the phase lag between land and ocean temperature. In this sense, an increased stratification after $2.7 \mathrm{Ma}$ caused the subarctic Pacific surface to be significantly warmer than the land in autumn. In autumn, the water vapor of the warm sea surface will supply moisture to the cold, northern American, continent favoring snow fall and thus the build-up of the Northern ice sheet.

\subsubsection{Second climate reorganization $\sim 2.2 \mathrm{Ma}$}

The second cooling step is observed in the tropics and the subtropics (Ravelo et al., 2004) and occurred under stable polar-climate and ice volume conditions. Recent studies found a stronger Walker Circulation (WC) and increased East-West temperature gradient in the tropical Pacific after $\sim 2.2 \mathrm{Ma}$ (Etourneau et al., 2010; Ravelo et al., 2004; Wara et al., 2005). The higher SST gradient has been linked to cooling of the East Equatorial Pacific (EEP), while the SST of the West Equatorial Pacific (WEP) remained stable during this period. Earlier investigations postulate that the temperature of the EEP depends on the strength and the position of the trade winds. The intensity of these winds, part of the Hadley Circulation (HC), varies with the pole- to equator temperature gradient (Rind, 1998). An enhanced atmospheric pressure gradient between the WEP and South East Asia is proposed to have caused an increased HC 2.2 Ma (Jia et al., 2008; Wang, 
1994). Evidences of the Benguela Upwelling System, situated in the Atlantic Ocean, also indicate stronger trade winds and enhanced HC (Etourneau et al., 2010). These evidences of strengthening of the trade winds can explain the registered cooling of the EEP and the stronger WC in the tropical Pacific. Etourneau et al. (2010) suggest that an increase in the HC and the WC may have acted as a negative feedback mechanism on Plio-Pleistocene climatic cooling by strengthening wind-driven upwelling intensity or thermocline shoaling, since both mechanisms trigger oceanic $\mathrm{CO}_{2}$ efflux to the atmosphere. Such a forcing mechanism could help explain the slowdown of ice sheet extension at high latitudes and atmospheric $\mathrm{CO}_{2}$ decline $\sim 2.4-2.0 \mathrm{Ma}$ (Etourneau et al., 2010).

\subsection{The Eltanin impact}

Another, less studied, event that could have affected the mid Pliocene climate is the Eltanin asteroid impact in the Bellinghausen Sea. The Eltanin impact was first discovered as an Ir anomaly in 1981 (Kyte et al., 1981) and is the only known asteroid impact in a deep-ocean basin. The latest datation, based on high-resolution integrated magnetobiostratigraphic analyses constrain the Eltanin impact age to $\sim 2.5 \mathrm{Ma}$ (Gersonde et al., 2005). The impact ripped up sediments as old as Eocene that have been re-deposited in a chaotic assemblage on and nearby the

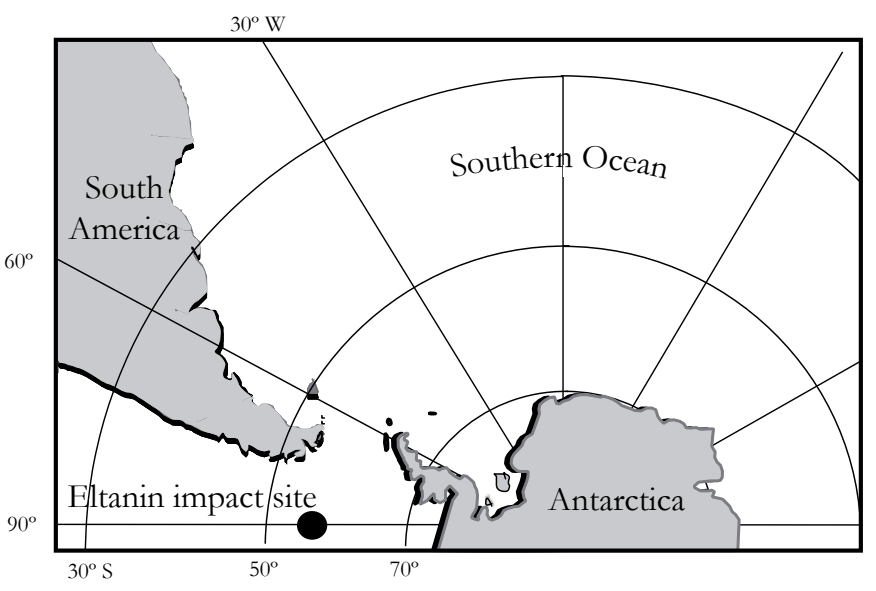

Fig. 1.7. Location of the the Eltanin asteroid impact. Modified from Flores et al. (2002) seamounts at the impact site. This is followed by a sequence sedimented from a turbulent flow at the sea floor, overprinted by fall-out of airborne meteoritic ejecta that settled trough the water column (Gersonde et al., 2005). One of themost remarkable characteristics of this impact deposit is the high concentration of melted $(87 \%)$ and unmelted $(13 \%)$ meteoritic material distributed across a large area of ocean floor. Impact deposits are now available from a total of more than 20 sediment cores collected in an area covering about $80,000 \mathrm{~km}^{2}$. The Eltanin asteroid size was around or larger than $1 \mathrm{~km}$ in diameter. This places the energy released by the impact at the threshold of those considered to cause environmental disturbance at a global scale. Tsunami modeling reveals that only few hours after the impact tsunamis with a height of more than 50 meters must have reached the Antarctic and South American coast lines, having potential to destabilize Antarctic ice shelf areas in the Pacific sector (Ward and Asphaug, 2002). Tsunami deposits found in Chile (Felton and Crook, 2003; Le Roux et al., 2008) have been tentatively related with the Eltanin. Scientists believe that these tsunamis may have had an effect on the climate by ejections of large amounts of salt water into the atmosphere (Gersonde et al., 1997). Gersonde et al. (2005) suggest that the impact could represents a possible transport mechanism explaining the presence of extinct Cenozoic microfossils in the transantarctic Sirius Unit. These microfossils were originally interpreted as evidence of a significant midPliocene reduction of the East Antarctic Ice Sheet. A study of the sediment cores of the Bellinghausen Sea, made by Flores et al. (2002), did not reveal significant changes in the calcareous plankton association for the interval immediately after the impact, but relatively low sedimentation rates compared to the interval before the impact and the appearance of extensive bioturbation after the impact may be indicative of certain paleoenvironmental changes immediately after the impact. ODP Site 1096 (at $1300 \mathrm{~km}$ of the impact site) 
was examined to find traces of the impact, but in this case no strong evidence related to this impact was found (Kyte, 2001). The consequences of this impact on the climate have not been quantified and it has not been demonstrated to which extent this impact had a global effect on the Pliocene climate (Flores et al., 2002; Gersonde et al., 1997; Gersonde et al., 2005).

Table 1.1 Summary of the most significant events that affected the Plio-Pleistocene climate

\section{AGE EVENT LOCATION INTERPRETATION}

\begin{tabular}{|c|c|c|c|}
\hline 5-3 Ma & $\begin{array}{c}\text { Closure of the } \\
\text { Indonesian } \\
\text { Gateway }\end{array}$ & $\begin{array}{l}\text { Southwest } \\
\text { Pacific }\end{array}$ & $\begin{array}{l}\text { Due to the closure of the Indonesian Gateway, the warm } \\
\text { water which originally flew through this gateway is } \\
\text { replaced by cold water leading to a significant cooling in } \\
\text { the Indian Ocean. The changes in the ocean circulation } \\
\text { that accompanied this event may have played an } \\
\text { important role in the aridification of Africa and also in the } \\
\text { NHG. }\end{array}$ \\
\hline $\pm 3 \mathrm{Ma}$ & $\begin{array}{l}\text { Mid Pliocene } \\
\text { Warmth }\end{array}$ & Global & $\begin{array}{l}\text { Period of global warmth, characterized by higher } \\
\text { temperatures (especially at high latitudes), higher } \\
\text { atmospheric } \mathrm{CO}_{2} \text { concentrations and sea levels up to } 25 \mathrm{~m} \\
\text { higher than at present. Recent studies suggest that } \\
\text { permanent El-Niño conditions were in great part } \\
\text { responsible for this sustained warmth. }\end{array}$ \\
\hline
\end{tabular}

The final closure of the CAS led to an increased salinity of the Carribean Sea, causing an intensification of the the

Final closure of the CAS

Carribean Ocean Gulf Stream. An increased supply of moisture to the North Atlantic (caused by a stronger Gulf Stream) favoured the intensification of the NHG.

$\pm 2.75 \mathrm{Ma} \begin{gathered}\text { Intensification Arctic Ocean } \\ \text { of the NHG }\end{gathered}$

Ice accumulation is highly intensified in the Arctic Ocean leading to a well developed Northern Hemisphere ice sheet. Scientist believe that this event is is the result of a gradual process influenced by different regional events that took place at different locations. The most signifcant processes are the closure of the CAS, the closure of the Indonesian Gateway and the stratification of the Subarctic Pacific.

\begin{tabular}{|c|c|c|c|}
\hline $\pm 2.7 \mathrm{Ma}$ & $\begin{array}{l}\text { Stratification } \\
\text { of the } \\
\text { Subarctic } \\
\text { Pacific }\end{array}$ & Subarctic Pacific & $\begin{array}{l}\text { The stratificiation, especially in autumn, of the Subarctic } \\
\text { Pacific enhanced the moisture supply to North America, } \\
\text { favoring the build-up of the Northern ice sheet. }\end{array}$ \\
\hline $\pm 2.2 \mathrm{Ma}$ & $\begin{array}{l}\text { Intensification } \\
\text { of the Walker } \\
\text { Circulation } \\
\text { and the Hadley } \\
\text { Circulation }\end{array}$ & Subtropcis & $\begin{array}{l}\text { The intensification of the Walker and the Hadley } \\
\text { Circulation leads toward a greater SST gradient in the } \\
\text { Equatorial Pacific, ending the permanent El-Niño } \\
\text { conditions. The intensified atmospheric ciruclation } \\
\text { enhances the wind-driven upwelling triggering } \mathrm{CO}_{2} \text { efflux } \\
\text { to the atmosphere, slowing down the Plio-Pleistocene } \\
\text { cooling. }\end{array}$ \\
\hline
\end{tabular}





\section{ChAPTER 2 : OCEANOGRAPHIC SETTING}

2.1. The Southern Ocean

2.2. The South Atlantic

2.3. The Tasman Sea 



\section{CHAPTER 2: OCEANOGRAPHIC SETTING}

\subsection{The Southern Ocean}

This work has focused on the Subantarctic Zone (SAZ) of the Southern Ocean (SO). The SO doesn't have physical boundaries and therefore the International Hydrographic Bureau (1937), among others, decided to divide it in three sectors: the Pacific, the Indian and the Atlantic (Fig. 2.1). However, from an oceanographic point of view the SO can be defined as the water mass that spreads between the Antarctic continent and the Subtropical Convergence or Subtropcial Front (STF), a definition that is adopted by most scientists (Fig. 2.1). The position of the STF, where the tropical and the subantarctic surface waters meet, varies seasonally and ranges between $38^{\circ} \mathrm{S}$ and $42^{\circ} \mathrm{S}$. The atmospheric circulation of the $\mathrm{SO}$ is dominated by strong westerlies, blowing in West-East direction (Fig. 2.1). These winds are concentrated between $35^{\circ} \mathrm{S}$ and $60^{\circ} \mathrm{S}$ and their strength increases with the latitude. The wind driven surface circulation is rather simple, compared with other oceans, and can be divided in a west wind drift and a east wind drift (Fig. 2.1). The west wind drift is dominant feature of the current system of the $\mathrm{SO}$ and is also known as the Antarctic Circumpolar Current (ACC), the only current that flows completely around the globe. The ACC is divided in three zones with each different temperature and salinity, which are separated by oceanic fronts. From North to South we can distinguish: The STF, The Subantarctic Front (SAF) and the Polar Front (PF) (Lutjeharms, 1985; Peterson and Stramma, 1991; Orsi, 1993). These fronts are characterized by steep temperature and/or salinity gradients. The largest variability is found at the STF where a steep temperature gradient of more than $5^{\circ} \mathrm{C}$ if found in less than $35 \mathrm{~km}$, and a salinity reduction of $1.2 \%$. The STF has a complex structure, including eddies and is an important region of enhanced primary productivity. The SAF is less marked both in temperature as in salinity. This front is situated at $45( \pm 2.5)^{\circ} \mathrm{S}$. The zone between the STF and the SAF is denominated the subantarctic zone (SAZ). The last important front is the PF, located at $\pm 50^{\circ}$ S. Almost

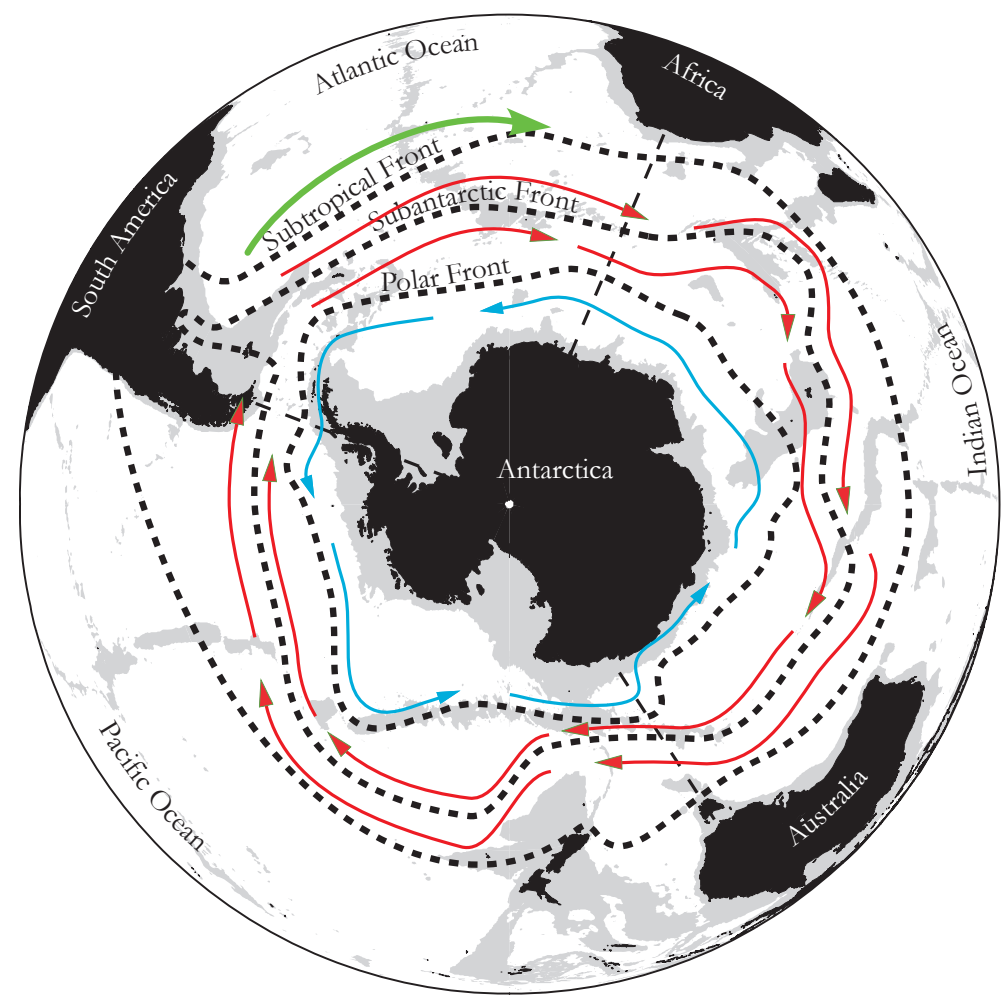

Fig. 2.1. Southern Ocean wind-driven circulation. The atmospheric circulation of the Southern Ocean is dominated by westerlies (green). The surface circulation of the Southern Ocean consist in a broad current flowing from East to West (The Antarctic Circumpolar Current, depicted in Red) and a narrower east-flowing current close to the continent (The periAntarctic coastal current), depicted in blue. The ACC has three different oceanic fronts which are indicated with dashed lines. The bathymetry is simplified and areas shallower than $3000 \mathrm{~m}$ are shaded in gray. Map was elaborated with the Ocean Data View software (Schlitzer, 2011). 
no changes in temperature and salinity are observed and the $\mathrm{PF}$ is associated with the $3.4^{\circ} \mathrm{C}$ isotherm and salinity its is 33.9\%o. The zone between the SAF and the PF is called the Polar Front zone (PFZ) and is characterized by an increased accumulation of biogenic silic and forms and important biogeographic limit for plankton communities.

The upwelling of deep water is fundamental for the biology of the SO, supplying the surface with nutrientrich deep water. Apart from local upwelling areas, the deep water circulation of the SO is driven by the formation of Antarctic Bottom Water (AABW) in different coastal areas of the Antarctic Continent (the Weddel Sea and in less extend the Ross Sea and Prydz Bay). The formation of this water mass is of vital importance for the global thermohaline circulation. Measurements of the AABW indicate that its temperature is $-0.5^{\circ} \mathrm{C}$ and salinity is $34.66 \%$, being the most dense water mass in the free ocean. Due to its large density, $\mathrm{AABW}$ flows along the bottom into all ocean basins, only restricted by the seafloor topography. During it course, AABW interacts with the overlying water masses. As it moves North it gets caught up in the AAC forming the Circumpolar Deep Water (CDW)( Fig. 2.2). The Antarctic superficial waters sink at the PF forming the Antarctic Intermediate Water mass. At the moment of its formation, this water mass is characterized by a temperature of $2.2^{\circ} \mathrm{C}$ and a salinity of $33.8 \%$.

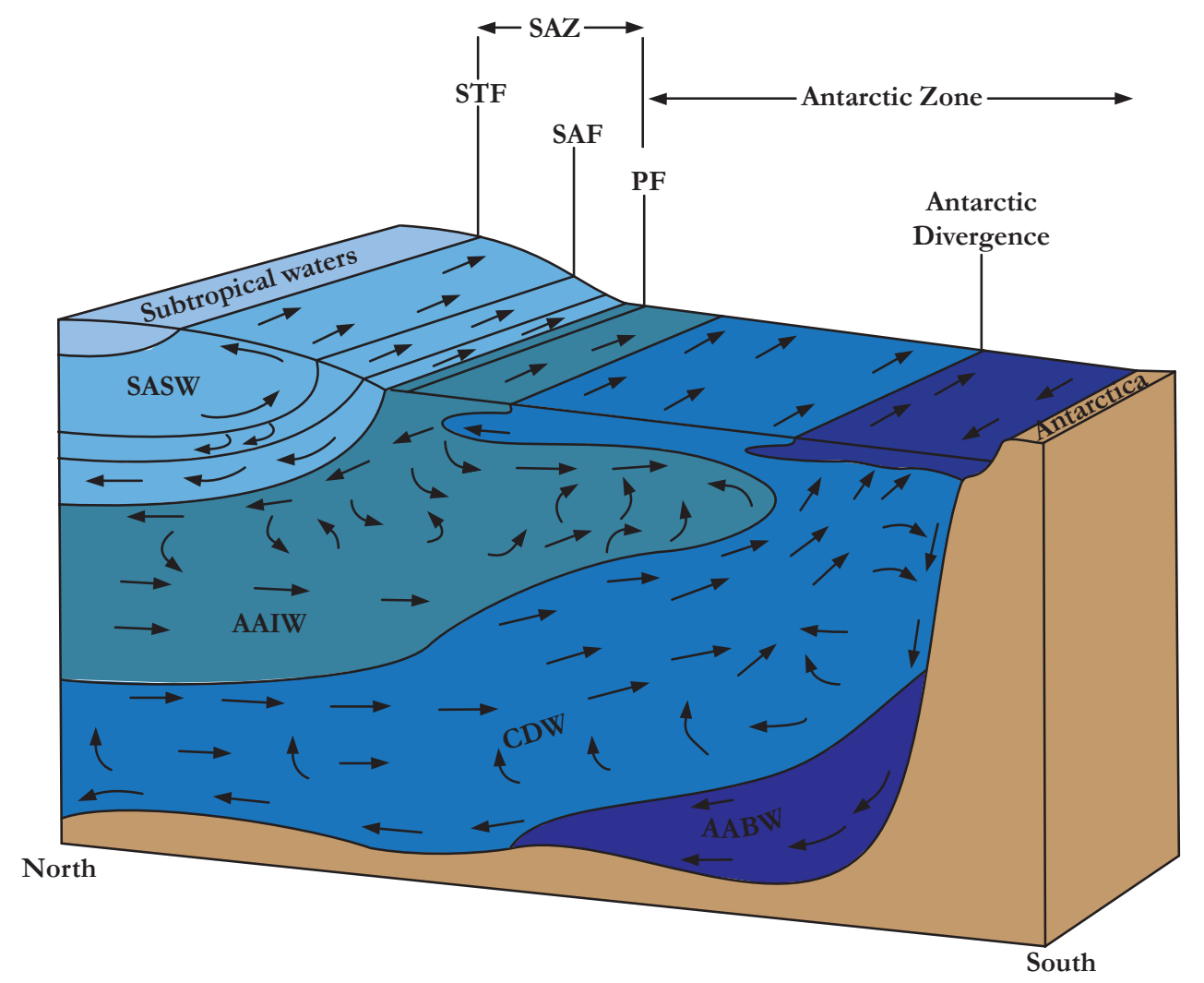

Fig. 2.2. Block diagram of the general thermohaline circulation in the Southern Ocean with indication of the diferent oceanic fronts: STF (Subtropical Front), SAF (Subantarctic Front) and PF (Polar Front). The different water masses are represented in different colors: AABW (Antarctic Bottom Water), CDW (Circumpolar Deep Water), AAIW (Antarctic Intermediate Water) and SASW (Subantarctic SurfaceWater). Modified from Tomzack and Godfrey (2003).

\subsection{The South Atlantic}

One of the study areas is located in SAZ of the South-East Atlantic. In the South-Atlantic, the STF, is 
placed at $42^{\circ} \mathrm{S}$ and is characterized by a temperature drop of $8.4^{\circ} \mathrm{C}$ (Lutjeharms, 1981; Lutjeharms and Valentine, 1984). The characteristic temperature decrease at the sea surface for the $\mathrm{SAF}$ is about $4^{\circ} \mathrm{C}$, from 9.0 to $5.1^{\circ} \mathrm{C}$ (Lutjeharms and Valentine, 1984) while the salinity drops from 33.89 to $34.11 \%$ (Allanson et al., 1981). The geographic position of the SAF generally lies at about $45^{\circ} \mathrm{S}$ (Lutjeharms, 1985; Peterson and Stramma, 1991).

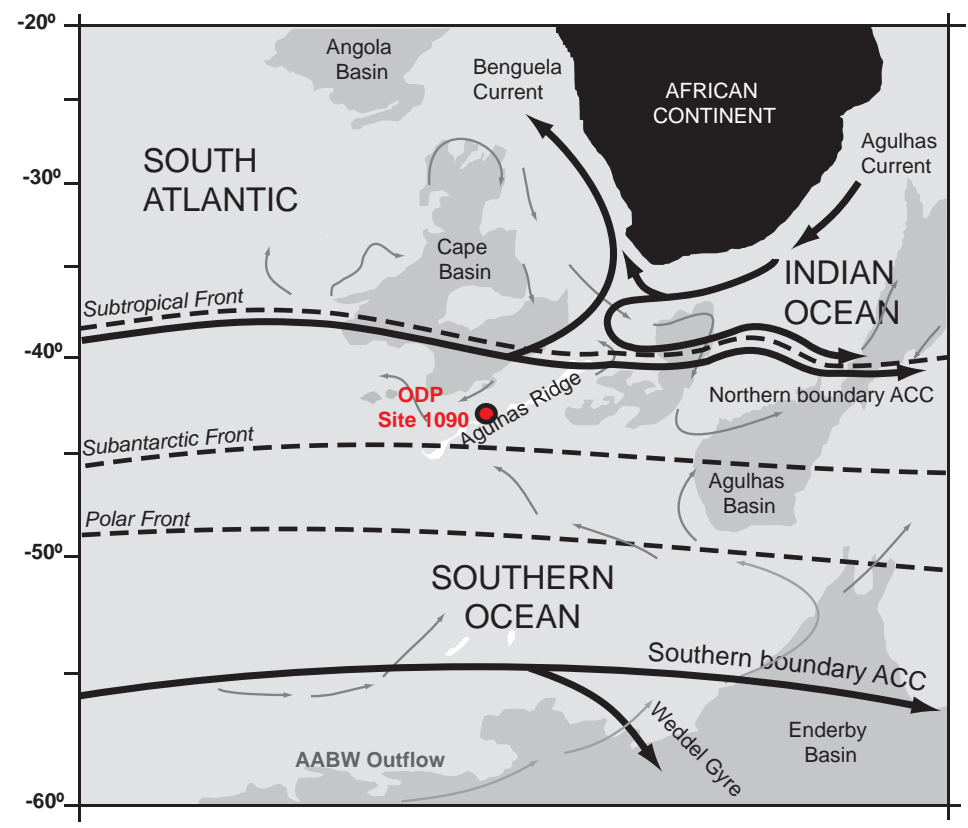

Fig. 2.3. Location of site 1090. Black arrows depict the surface-ocean circulation, gray arrows indicate the flow pattern of bottom contour currents. The discontinuous lines show the actual position of the oceanic Fronts (modified from Kuhn and Diekmann, 2002).

At the study location the main oceanographic feature is the ACC, flowing from West to East (Fig. 2.3). Another important element of the surface circulation is the influence of distal eddies of the Agulhas Current Retroflection introduced from the Indian Ocean. The Agulhas Current (AC) is the western boundary current of the South Indian Ocean that flows down the East coast of Africa from $27^{\circ} \mathrm{S}$ to $40^{\circ} \mathrm{S}$ (Gordon, 1985). The AC is characterized by temperatures above $17^{\circ} \mathrm{C}$ and salinities below $35.5 \%$. Once it reaches the South Atlantic, the current turns back on itself and flows back into the Indian Ocean (Agulhas Return Current). At the time of retroflection, anticyclonic eddies are formed and move in south-west direction. These eddies enclose pools of relatively warm and saline stratified Indian Ocean water whose temperature is more than $5^{\circ} \mathrm{C}$ warmer and the salinity is $0.3 \%$ greater than the South Atlantic surface water (Gordon, 1985).

The South Atlantic Ocean receives water from the North Atlantic, the Weddell Sea and the Antarctic

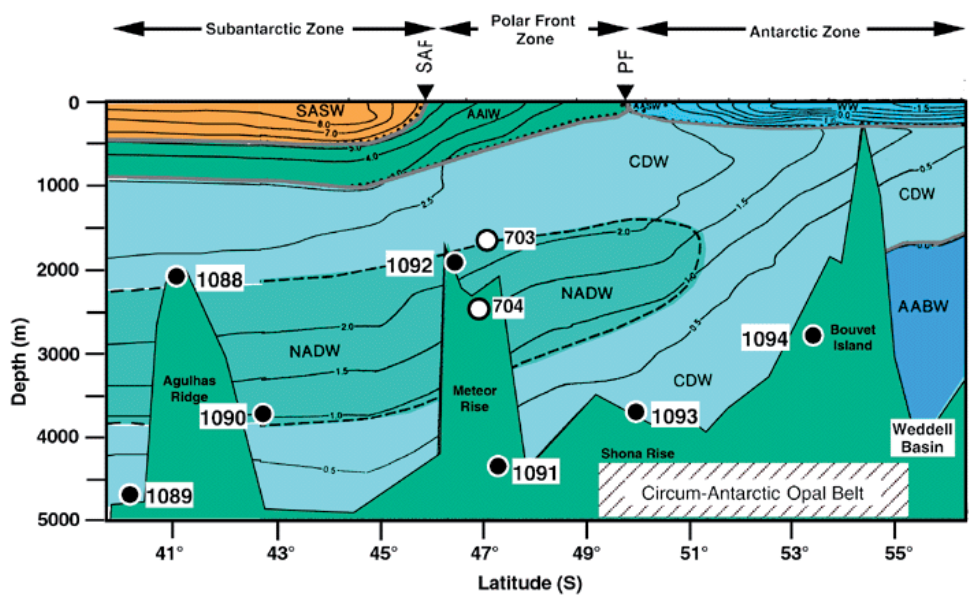

Fig. 2.4. Location of ODP site 1090 (and the other sites of LEG 177) in the water column. The different colors indicate the different water masses: AABW: Antarctic Bottom Water; CDW: Circumpolar Deep water; NADW: North Atlantic Deep Water, AAIW: Antarctic Intermediate Water; SASW: Subantarctic Surface Water The position of the different fronts are indicated above (PF: Polar Front \& SAF: Subantarctic Front). Figure from (Gersonde et al., 1999a). 
Circumpolar Current (ACC) which makes it an important area to study the variation of the deep-water circulation. AABW that is formed in the Weddel Sea expands north into the South Atlantic, flowing below $4000 \mathrm{~m}$. In the East Atlantic, the AABW outflow is stopped by the Walvis Ridge and is deflected eastwards along the shelf of the South African continent into the Indian Ocean.

Above the AABW flows the Circumpolar Deep Water (1000-4000 m) (Fig. 2.4). This water mass is a mixture of deep water from all oceans and is the most important water mass from the ACC. The upper branch of the CDW contains oxygen-poor water from all oceans. The lower (deeper) branch contains a core of highsalinity water from the Atlantic, including contributions from the north Atlantic deep water mixed with salty Mediterranean Sea water. CDW has the same density as NADW but is colder and fresher. As the different water masses circulate around Antarctica they mix with other water masses with similar density.

Above the CDW we can find AAIW, which is characterized by its low salinity. In the eastern basins, its movement is masked by eddies, particularly Agulhas Current eddies propagating northward. Observations along the South African continental rise near $1000 \mathrm{~m}$ depth (Nelson, 1989) indicate that AAIW participates in the cyclonic motion of abysal water masses in the Cape Basin, even though the Walvis Ridge does not pose a barrier to flow at AAIW level. AAIW is formed mostly in the eastern south Pacific and enters into the Atlantic Ocean through the Drake Passage. As a consequence Atlantic AAIW differs little from AAIW in the other two oceans. Close to the formation region it has a temperature near $2.2^{\circ} \mathrm{C}$ and a salinity of about $33.8 \%$. Mixing with water from above and below erodes the salinity minimum; by the time AAIW reaches the STCZ it has properties closer to $3{ }^{\circ} \mathrm{C}$ and about $34.3 \%$. Above the AAIW, we can find Subantarctic Surface Water (SASW) (Fig. 2.2). This water mass is vertically well mixed and rich in oxygen and is formed by deep water convection on the equator side of the ACC, directly North of the SAF.

\subsection{The Tasman Sea (South Pacific)}

The Tasman Sea stretches from the Tasman Front, that separates it from the Coral Sea, until the STF (Fig. 2.5). ODP site 1172 is located in the Tasman Sea ( $43^{\circ} 58^{\prime} \mathrm{S}$ and $\left.149^{\circ} 56^{\prime} \mathrm{E}\right)$. The dominant feature in the study region is the STF, a dynamic frontal boundary between comparatively warm, salty subtropical Tasman

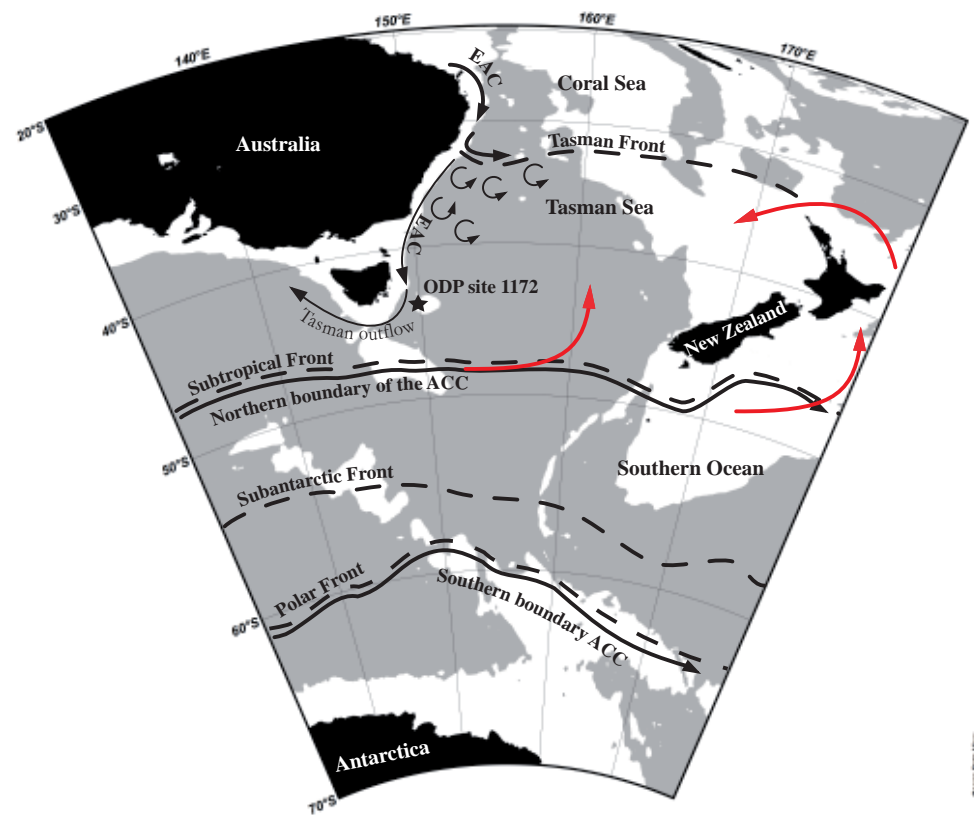

Fig. 2.5. Location of ODP site 1172 and dominant oceanographic features of the study area. The most important surface currents that affect the study area are (i) the East Australian Current (EAC) and its eddy field that flow south along the Australian coast and (ii) the Antarctic Circumpolar Current (ACC). The path of the Antarctic Intermediate Water is indicated in red. The different oceanic fronts are indicated by dashed lines.The ocean bathymetry is divided in areas with depths $>3000 \mathrm{~m}$ (gray) and areas $<3000 \mathrm{~m}$ (white). The map was elaborated with the Ocean Data View software (Schlitzer, 2011). 
Sea waters and cooler, fresher Subantarctic waters of the SO. The low salinity water South of the STF arises from a rainfall maximum at the latitudes of the Roaring Forties (Garner, 1959).The STF is characterised by a region of enhanced surface temperature and salinity gradients, and typically extends to $200-300 \mathrm{~m}$ depth. For paleoceanographic studies the STF is associated with the $15^{\circ} \mathrm{C}$ surface isotherm in February, the $10^{\circ} \mathrm{C}$ isotherm in August and the 34.7-34.8\%o isohaline (Garner, 1959), see also Belkin and Gordon (1996) for additional criteria for the STF identification).

The Tasman Sea is influenced by the East Australian Current (EAC), the western boundary current of the South Pacific. This is the weakest of all boundary currents and its low transport volume is partly a consequence of flow through the Australian Mediterranean Sea. The EAC forms after bifurcation of the South Equatorial Current upon reaching the Queensland coast $\left(\sim 14-18^{\circ} \mathrm{S}\right)$ and then moves poleward along the Australian coast. At around $30^{\circ} \mathrm{S}$ the EAC is deflected East, towards New Zealand (Fig. 2.5). The path of the current from Australia to New Zealand is known as the Tasman Front, which marks the boundary between the warm water of the Coral Sea and the colder water of the Tasman Sea. This front develops wave-like disturbances (meanders) and associated disturbances in the thermocline which eventually travel westward with Rossby wave speed. When the waves impinge upon the Australian coast they separate from the main current and turn into eddies. Therefore, the EAC spawns many anticyclonic (warm core) and few cyclonic (cold core) eddies. When the eddy becomes separated from the main current it will maintain its speed for many months while its hydrographic structure changes. Remnants of eddies in the form of subsurface layers of uniform temperature and salinity are abundant south of the Tasman Front and are characteristic of the upper $500 \mathrm{~m}$ of the Tasman Sea. The residue of the EAC transport continues southward along the Australian coast as far as Tasmania and then turns westward into the Eastern Indian Ocean (Tasman Outflow) with an important impact on the global ocean circulation (Speich et al. 2002). South of the STF, the ACC flows in eastward direction (Fig. 2.5).

ODP site 1172 is recovered at $2620 \mathrm{~m}$ depth, within the AABW-CDW interface. Communication between the SO and the Pacific basins is much more restricted by the topography than in the other oceans. Flow of water from the Australian-Antarctic into the Southwest Pacific Basin and the Tasman Sea is blocked below $3500 \mathrm{~m}$ level. There are two entry routes of AABW into the study area. All originate from the northern flank of the ACC and therefore carry AABW in the form of CDW. The Western route flows East of Australia and is blocked by topography near $20^{\circ} \mathrm{S}$ and is of little importance outside the Tasman and Coral Seas (Fig. 2.5). The second route flows East of New-Zealand and spreads gradually northwards. The deep circulation consists in a northward movement of deep waters in the western boundary currents with slow return circulation through the eastern basins. Movement of the AAIW in the western South Pacific Ocean is strongly influenced by the topography. The presence of New Zealand results in AAIW entering the Tasman Sea along two paths. AAIW with minimum salinity less than $34.4 \%$ enters from the South, taking the shortest route from the Polar Front. It does not spread very far northward since it is being opposed by a second source of AAIW supply which enters the Tasman Sea from the North (Tomzack and Godfrey, 2003). 



\section{HAPTER 3 : MATERIAL AND METHODS}

3.1. Material
3.1.1. ODP site 1090
3.1.2. ODP site 1172

3.2. Methods

3.2.1. Sample preparation

3.2.2. Counting techniques

3.2.3. Stable isotope measurements 



\section{CHAPTER 3: MATERIAL AND METHODS}

\subsection{Material}

To achieve the objectives of this study, two sediment records of two different ODP sites in the Southern Ocean were analyzed. The first sediment record was recovered at ODP site 1090 (during LEG 177) situated in the eastern South Atlantic (Fig. 3.1). The second sediment record was recovered at ODP site 1172 (during LEG 189) and is situated in the Tasman Sea (Southwest Pacific) (Fig. 3.1).

LEG 177 (South-Atlantic)

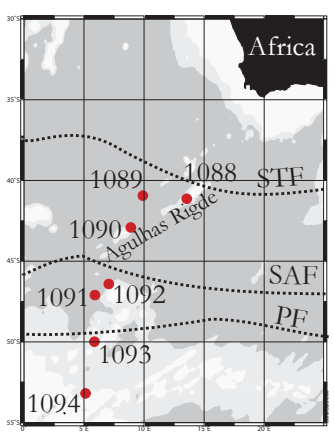

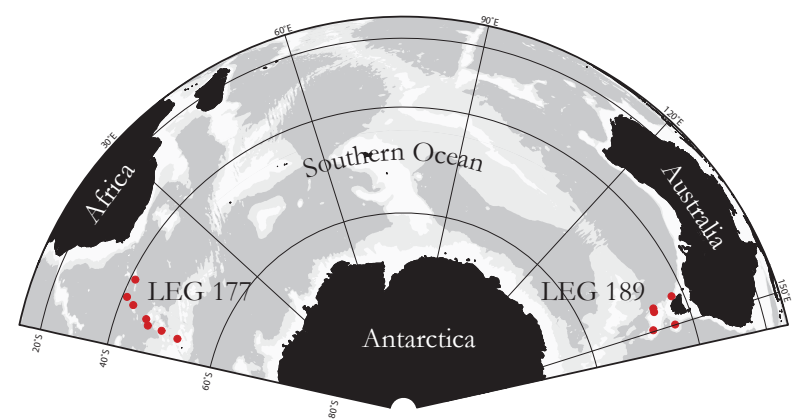

LEG 189 (South-Pacific)

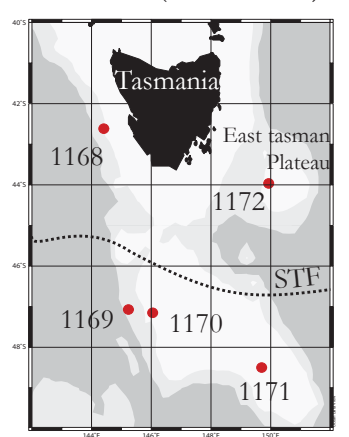

Fig. 3.1. Location of the sediment records. The different sites are indicated by red dots. The different oceanic fronts located in the study area are: the subtropical front (STF), the Subantarctic Front (SAF) and the Polar Front (PF).

\subsubsection{ODP site 1090}

Sediments of the South Atlantic sector of the Southern Ocean were cored during ODP Leg 177. During this leg, seven sites along a North-South transect (from 41 to $53^{\circ} \mathrm{S}$ ) were drilled to study the paleoceanographic history of the Antarctic region (Fig. 3.1). From these seven sites we have selected site 1090, located at $42^{\circ}$ $\mathrm{S}$, in the central part of the SAZ. Site 1090 is situated on the southern flank of the Agulhas Ridge at a water depth of $3702 \mathrm{~m}$. The position of the site makes it ideal for monitoring the movements of the oceanic fronts and their influences on the nannoplankton community. The water depth is above the calcium carbonate compensation depth and ensures preservation of calcareous microfossils during glacial and interglacial periods. Sediments were recovered using an advanced piston corer (APC) for the most superficial meters and an extended core barrel (XCB) for the lower sections.

For this study, sediments from hole 1090B and 1090D were studied. This was necessary because after converting the initial depths, expressed in meters below seafloor (mbsf), to composite depths (mcd) there was a gap between core 6 and core 7 of hole 1090B (See appendix for details). Extra sediment samples were taken of $1090 \mathrm{D}$ to fill up the gap. The sample resolution of hole $1090 \mathrm{~B}$ was every $10 \mathrm{~cm}$ and every $5 \mathrm{~cm}$ for hole 1090D. A total of 232 samples, between 44.88 and $58.31 \mathrm{mcd}$, were studied.

The sediment shows alternations between pale gray foraminiferal nannofossil ooze and greenish gray mud and diatom-bearing nannofossil ooze (Fig. 3.2.; Shipboard Scientific Party, 1999). Following the visual core descriptions published in the initial report of Leg 177, bioturbation is rare for $1090 \mathrm{~B}$ and moderate for 1090D. The average carbonate content is $61 \%$ (Venz \& Hoddell, 2002). 


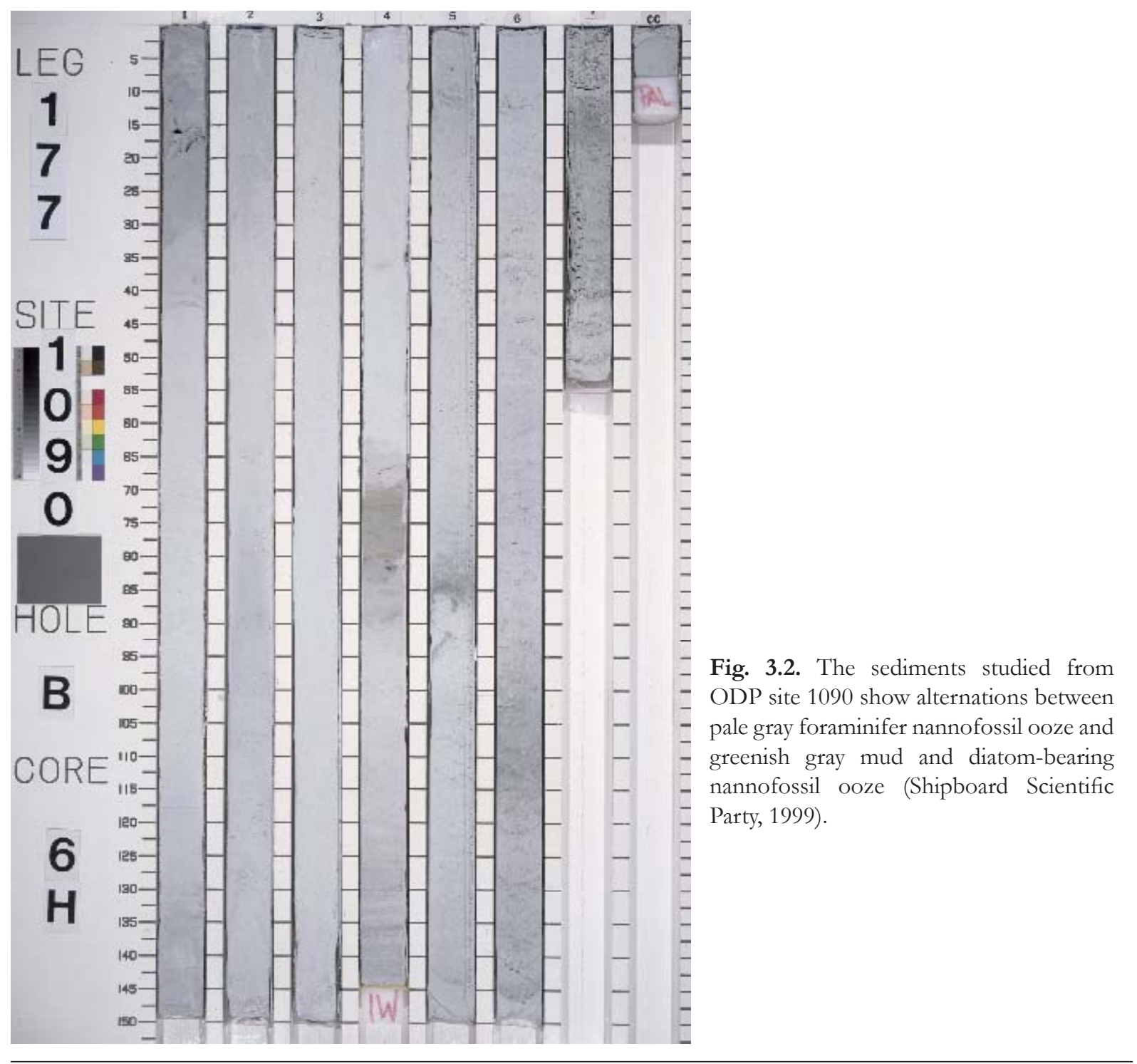

3.1.2. ODP site 1172

The sediments of the South Pacific were recovered during LEG 189. During this campaign five sites were drilled South of Tasmania (Fig. 3.1). Site 1172 is located on the flat western side of the East Tasman Plateau (Tasman Sea), at $44^{\circ} 57^{\prime} \mathrm{S}$ and $149^{\circ} 55^{\prime} \mathrm{E}$ (Fig. 3.1).

For our study we have used sediments from hole 1172A and 1172B. Both holes were APC cored. Material of hole $1172 \mathrm{~B}$ was necessary to cover a gap $(0.76 \mathrm{~m})$ between core 4 and core 5 of hole $1172 \mathrm{~A}$. Extra sediment samples were taken of $1172 \mathrm{~B}$ to fill up the gap. The samples were taken every $10 \mathrm{~cm}$. A more complete overview of the studied samples and their corresponding depths is attached in the appendix. A total of 316 samples, between 18.05 and $47.42 \mathrm{mcd}$, were studied.

Site 1172 is situated at $2620 \mathrm{~m}$ depth, well above the present lysocline that is estimated at $3600 \mathrm{~m}$ in the west Tasman Sea (Martinez, 1994). The lithologies of the sediments are white foraminifer nannofossil oozes and foraminifer-bearing nannofossil oozes and bioturbation is only rarely seen (Fig. 3.3; Shipboard Scientific Party, 2001). 


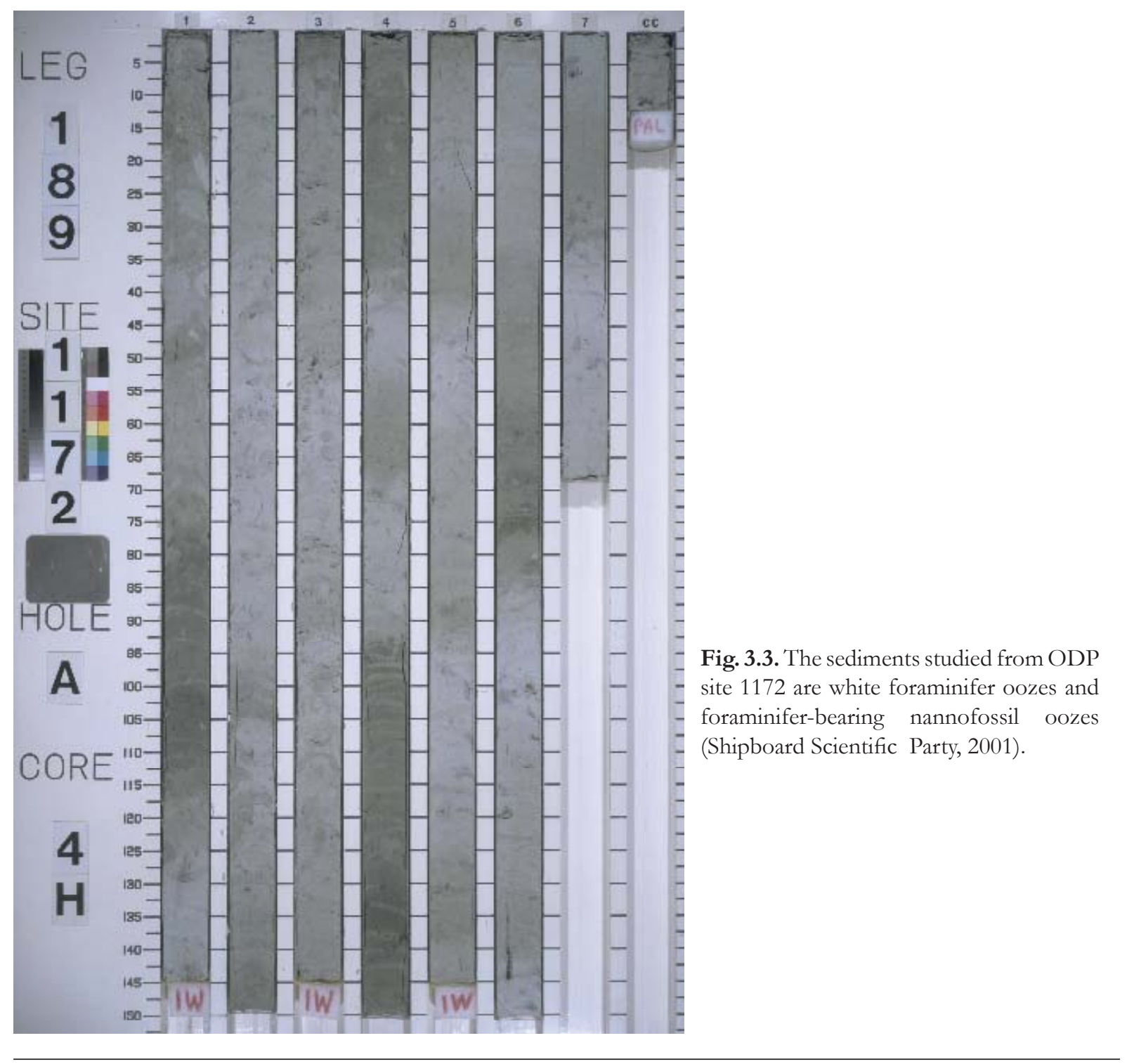

\subsection{Methods}

\subsubsection{Sample preparation}

Coccolith slides of ODP sites 1090 and 1172 were prepared using the decantation method of Flores and Sierro (1997), a procedure that allows calculation of the number of coccoliths per gram of sediment. For the preparation of each slide, 0.2 (or 0.1 ) g.of sediment was used as an initial weight. The sediment is mixed with $10 \mathrm{ml}$ buffered water $\left(\mathrm{H}_{2} \mathrm{O}+\mathrm{NaHCO}_{3}+\mathrm{Na}_{2} \mathrm{CO}_{3}\right)$. This solution is treated with ultrasounds during approximately 10 seconds. In the next step, a small quantity (between 100 and $200 \mu \mathrm{l}$ ) of the sedimentbuffered water solution is extracted with a micropipette and dropped on a cover-slide in a petri dish (Fig. 3.4). The petri dish was previously filled with a solution of buffered water and unflavored gelatin. During the following \pm 10 hours the sediment settles on the cover-slide. After this, the liquid fraction is extracted from the petri dish with cellulose strips (Fig. 3.4). Finally the cover slides are mounted on a smear slide using Canada Balsam and are ready for observation under the light microscope. 


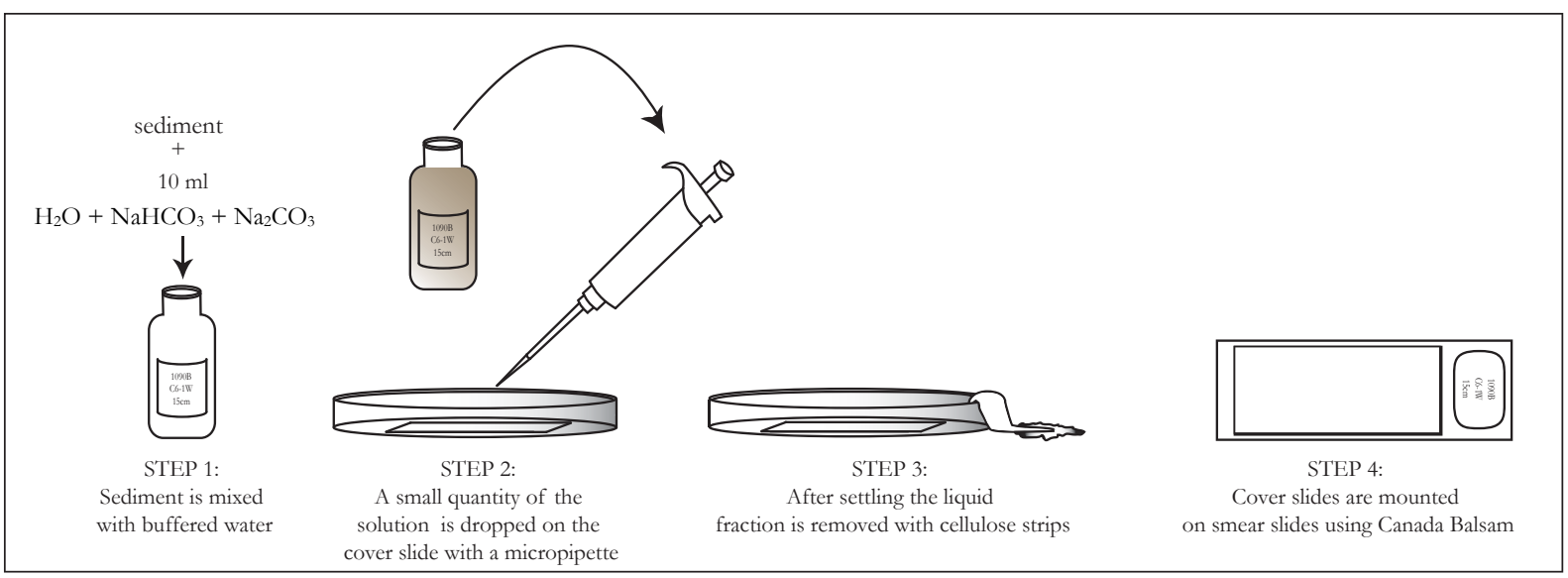

Fig. 3.4. Sample preparation using the decantation method of Flores and Sierro (1997).

This technique allows us to estimate nannofossil accumulation rates (NAR; coccoliths $\mathrm{cm}^{-2} \mathrm{ka}^{-1}$ ) after consideration of the density and the linear sedimentation rates. The NAR values can be used as a proxy for the coccolithophore productivity. Bulk densities were taken from the ODP reports, and linear sedimentation rates were calculated using the oxygen isotope stratigraphy. In addition to the total NAR, the counting procedure, allowed us to calculate the relative abundance (\%) and the NAR of the most abundant taxa.

During a short stay in the University of Kiel, samples were analyzed under the scanning electronic microscope (SEM) to improve taxonomy. For their preparation the same decantation method was used. The only difference is that after the sediment settles on the cover-slide in the in the petri dish, the cover-slide is fixed on an

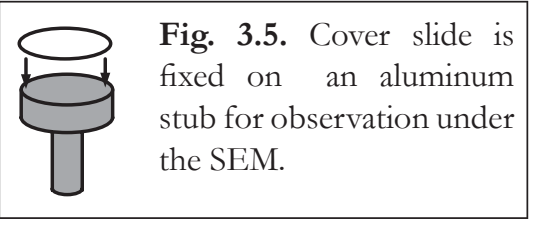
aluminum stub and sputtered with gold/Paladium (Fig. 3.5).

\subsubsection{Counting techniques}

Counting was done at 1000x magnification using a polarized light microscope (Nikon eclipse 80i) and was proceeded as followed: during a first analysis, all nannofossils were identified (if possible) at species level and counting continued, observing random visual fields of homogenously distributed samples, until a total number of at least 400 liths was reached. After this a second analysis was performed. The second analysis only focuses on the rare species. A species was considered rare if its relative abundance never exceeded $5 \%$ of the total assemblage. Again random visual fields were observed, but now only rare species were counted. A total of 25-30 visual fields were observed.

\subsubsection{Stable isotope measurements}

For ODP site 1172, stable isotopic analyses from both planktonic as benthic foraminifera were preformed every $10 \mathrm{~cm}$. Samples for isotopic analyses were washed over a $63 \mu \mathrm{m}$ sieve and the residues were dried and dry-sieved again using a $150 \mu \mathrm{m}$ sieve. For the benthic foraminifera, minimum 5 individuals of Cibicidoides wuellerstorfi from the fraction $>150 \mu \mathrm{m}$ were picked. In absence of sufficient individuals of C. wuellerstorfi, either Cibicidoides spp. or Uvigerina perigrena were picked (Fig. 3.6). The values of U. perigrena were corrected using a correction factor -0.64 for $\delta^{18} \mathrm{O}$ and $+0.79 \delta^{13} \mathrm{C}$. The correction factors were defined as the mean difference between the $C$. wuellerstorfi and the $U$. perigrena record. To obtain isotope measurement of the 
planktonic foraminifera, 6-10 individuals of Globigerina bulloides (Fig. 3.6) larger than $150 \mu \mathrm{m}$ were used. Foraminiferal test were soaked in $15 \% \mathrm{H}_{2} \mathrm{O}_{2}$ to remove organic matter, and cleaned sonically in methanol to remove fine-grained particles. Oxygen and carbon isotopic values were measured at Christian-Albrechts University of Kiel using a Finnigan MAT 251 mass spectrometer with an analytical error better than \pm 0.07 $\%$ for $\delta^{18} \mathrm{O}$ measurements. All isotope results are reported in standard delta notation relative to V-PDB (Coplen, 1996).

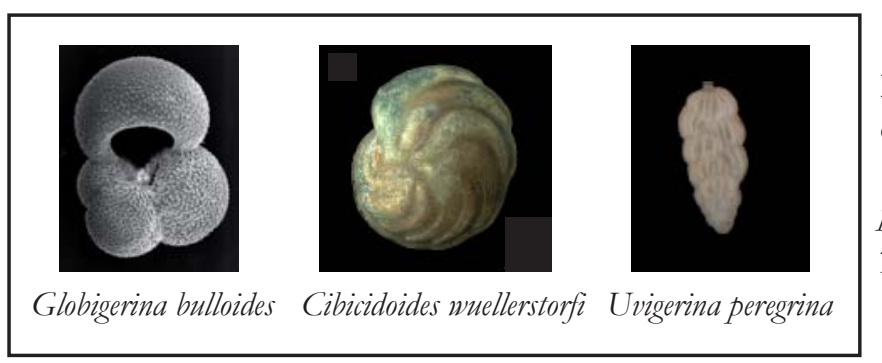

Fig. 3.6. Foraminifera species used for $\delta^{18} \mathrm{O}$ analysis. From left to right: $G$. bulloides (planktonic), C. wuellerstorfi (benthic) and $U$. peregrina (benthic). Photos were taken from www. palaeo-electronica.org 



\section{HAPTER 4: COCCOLITHOPHORES}

4.1. Introduction

4.1.1. General Characteristics

4.1.2. Life cycle

4.1.3 Coccolithophore distribution

4.2. Sedimentation and preservation in the sediments

4.2.1. Sedimentation

4.2.2. Dissolution

4.3. Coccolithophore taxonomy and ecological affinities

4.3.1. Cocccolithus pelagicus

4.3.2. Calcidiscus leptoporus

4.3.3. Reticulofenestra

4.3.4. Gephyrocapsa

4.3.5. Helicosphaera carteri

4.3.6. Helicosphaera sellii

4.3.7. Subtropical taxa 



\section{CHAPTER 4: COCCOLITHOPHORES}

\subsection{Introduction}

\subsubsection{General characteristics}

Coccolithophores are small (3-40 $\mu \mathrm{m})$ unicellular photosynthesing planktonic organisms, belonging to the Division Haptophyta and the Class Pyrmensiophyceae (Hibberd, 1976). Traditionally, they are described as autotrophic organisms although recent studies indicate that mixotrophy is relatively common among coccolithophores (Aubry, 2009; Liu et al., 2009). The majority of living coccolithophores presents motil and non-motil stages. The motil stages possess two subequal to unequal flagella which lack any hair-like appendages. One of the characteristics of the Prymnesiophyceae is the presence of a haptonema in cells that have a motile stage (Fig. 4.1). The haptonema is a flagellum-like appendage that is unique because it doesn't beat like the other flagella. In some coccolithophore families the haptonema is strongly reduced or vestigial, suggesting that it seems to be a less important organelle in the biology of certain coccolithophores. The function of the haptonema is still largely unknown; among the possible functions are: attachment to the substratum

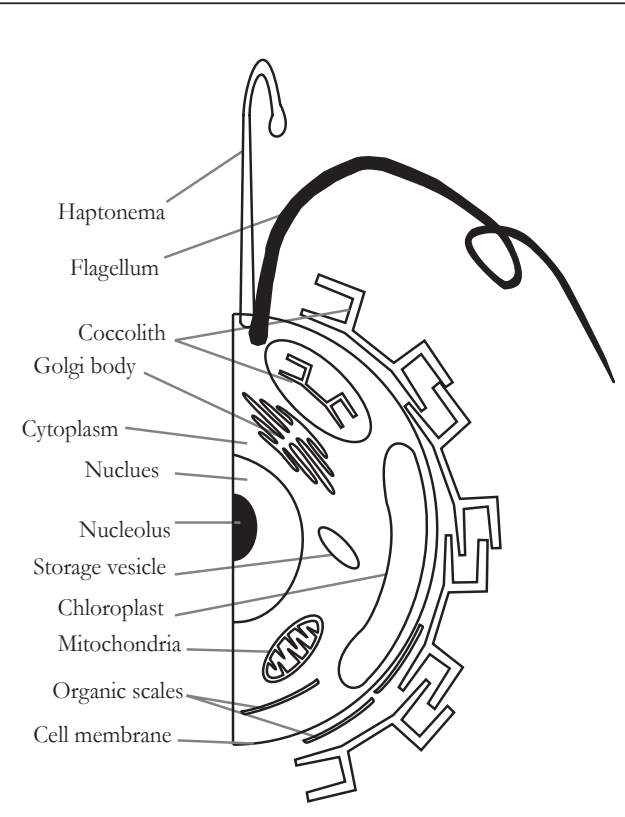

Fig. 4.1. Coccolithophore cell. General cell biology of a coccolithophore cell. (Leadbeater, 1971), a sensory or tactile organelle or a food capturing device (Kawachi et al., 1991).

Coccolithophores are distinguished from other prymnesiophytes, as well as from other plankton, by their ability to form calcified plates that cover their cells that are called coccoliths. The coccoliths are formed by a bio mineralization process inside the cell in which calcium and carbonate ions come together to form calcite $\left(\mathrm{CaCO}_{3}\right)$ which is extruded to the exterior. Individual $\mathrm{CaCO}_{3}$ elements are deposited in characteristic patterns and the coccoliths can be divided in three groups: heterococcoliths, holococcoliths and nannoliths (Fig. 4.2). Heterococcoliths are formed of crystal elements with a different shape and size and holococcoliths consist of identical crystal elements. Nannoliths have an anomalous structure and lack of typical features of heteroand holococcoliths. Holococcoliths are more easily disintegrated and therefore are less commonly found in the fossil record. The final form of the coccolith is used in the taxonomic subdivision of coccolithophores (See section 4.3).

The ultimate reason, why coccolithophores produce their coccoliths is still under debate. The most argued functions for coccoliths are: (1) they protect the cells from osmotic, chemical or physical shocks, (2) they protect the cells from predation and virus attacks, (3) during their formation, the chemical reaction of calcification $\left(\mathrm{Ca}^{2+}+\mathrm{HCO}_{3} \rightarrow \mathrm{CaCO}_{3}+\mathrm{CO}_{2}+\mathrm{H}_{2} \mathrm{O}\right)$ aids photosynthesis $\left(6 \mathrm{CO}_{2}+6 \mathrm{H}_{2} \mathrm{O} \rightarrow \mathrm{C}_{6} \mathrm{H}_{12} \mathrm{O}_{6}+6\right.$ $\left.\mathrm{O}_{2}\right)$, (4) they protect the cells from light, enabling them to live higher in the water column, (5) they attract the 
light and thus allow the coccolithophores to live deeper in the water column than other plankton, (6) They influence the sinking rate of the cells and (7) a layer of water can get trapped between the coccosphere and the cell, acting as chemical buffer and enhancing nutrient absorption. No direct evidences have been found that support one single function and most scientists agree that the coccoliths don't have a single function but have evolved to fulfill a range of functions depending on their ecological niche.

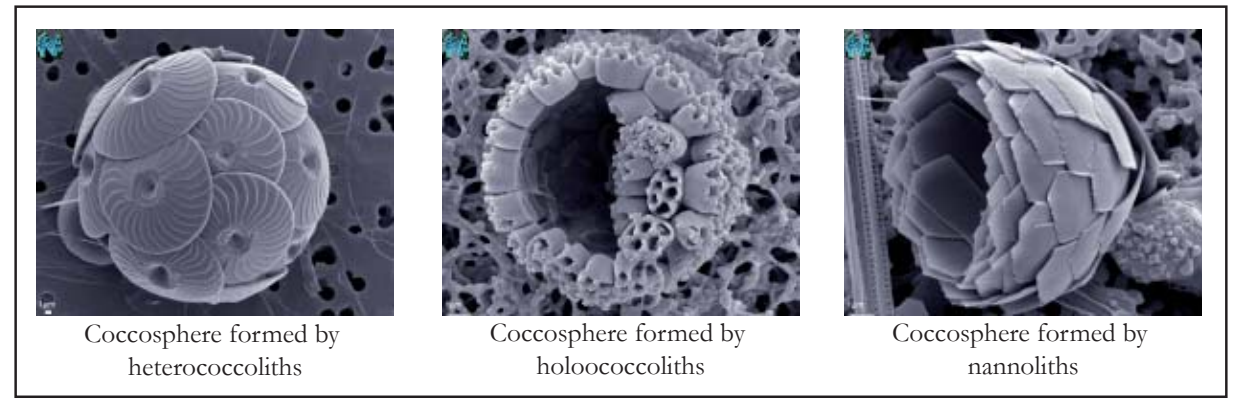

Fig. 4.2. The three different groups of coccoliths. From left to right: heterococcoliths, holococcoliths and nannoliths. Images taken from www.nannotax.org

\subsubsection{Life cycle}

Despite the increasing knowledge of coccolithophores, relatively little is known about their life cycles (Klaveness and Paasche, 1979). This is mainly due to the lack of precise culture and nutritional requirements for the majority of species, leading to cultures where only single cells can be isolated. The fact that some of the coccolithophore species may present a mixotrophic nutritional regime largely explains the experienced difficulties during culture experiments (Liu et al., 2009). The coccolithophore life cycle is heteromorphic, presenting haploid and diploid generations which can reproduce both asexually as sexually (Fig. 4.3). Generally, the haploid stage is motile and forms holococcoliths and the diploid stage is non-motile and forms heterococcoliths (Billard, 1994). The dominant reproductive mode is asexual reproduction and occurs, in motile and non-motile generations, through binary fission followed by mitotic division. During this process, the coccoliths are redistributed on the daughter cells. Coccolithophores also undergo sexual reproduction through meiosis (passing from a diploid to a haploid stage) and syngamy (passing from a haploid to a diploid stage). During the moment of life-cycle phase transition, combination cells having both heterococcoltihs as holococcoliths can be found (Fig. 4.3).

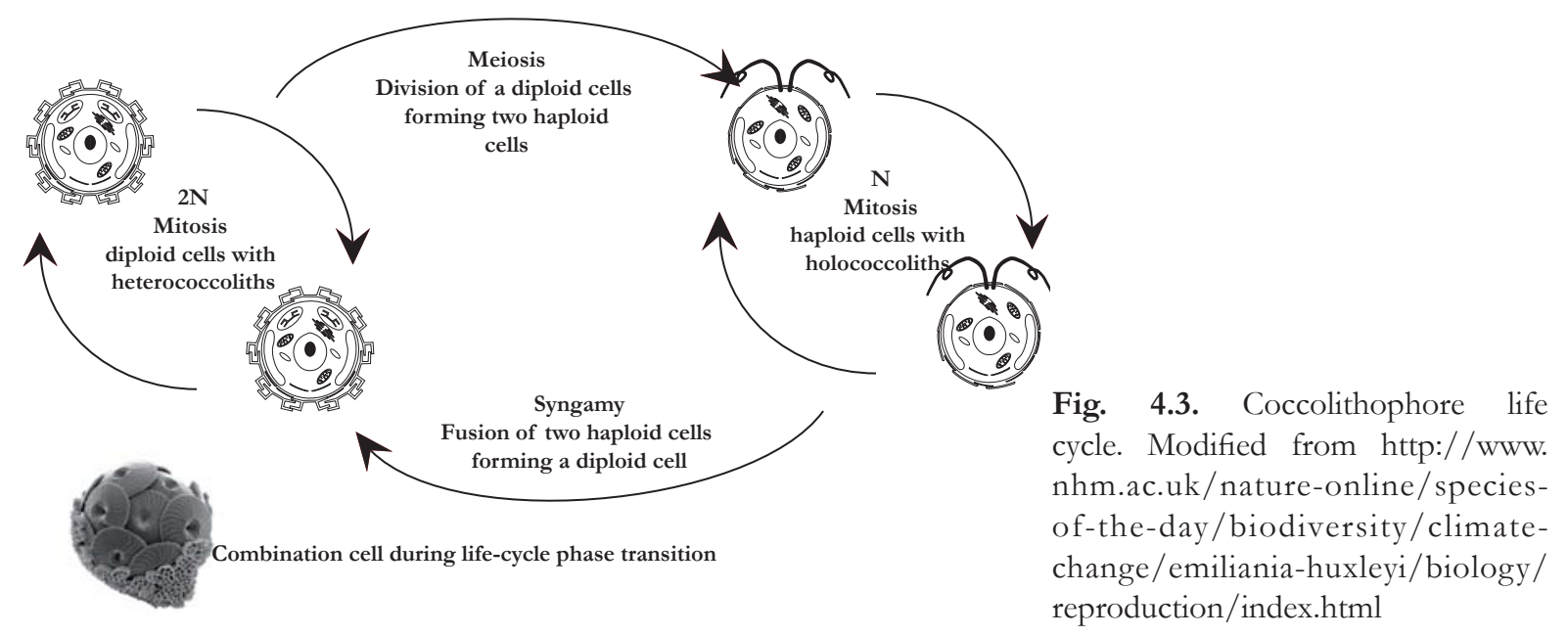




\subsubsection{Coccolithophore distribution}

Coccolithophores can be found in the whole global ocean, with exception of the Antarctic zone of the Southern Ocean (South of the Polar Front). Despite their cosmopolite distribution, they generally are more successful in warm, oligotrophic and stratified waters. From a global perspective, coccolithophore diversity is highest at low latitudes and decreases towards the poles. Despite the low diversity in subpolar regions, few species can form an important part of the phytoplankton. Coccolithophores are sensitive to a variety of environmental factors such as: light, temperature, salinity, turbity, nutrient content. A lot of effort has been made to decipher which environmental factors can be associated with the different coccolithophore species (the environmental preferences of the individual species will be discussed the next section). In most cases, a combination of various environmental factors, together with genetic alterations (intraspecific evolution), will finally determine the geographic distribution of the different coccolithophore species. Roughly, the coccolithophores can be divided in five major biogeographic zones: Subarctic, Temperate (or transitional), Subtropical (or Central), Tropical (or Equatorial) and Subantarctic (Fig. 4.4). These biogeographic areas are separated by dynamic boundaries that vary not only seasonally but also over geological time. The fact that the biogeographic ranges of the different species changes over time, converts them in an important tool for studying the climate of the past, a key issue of this work.

\section{Coccolithophore biogeographic zones}

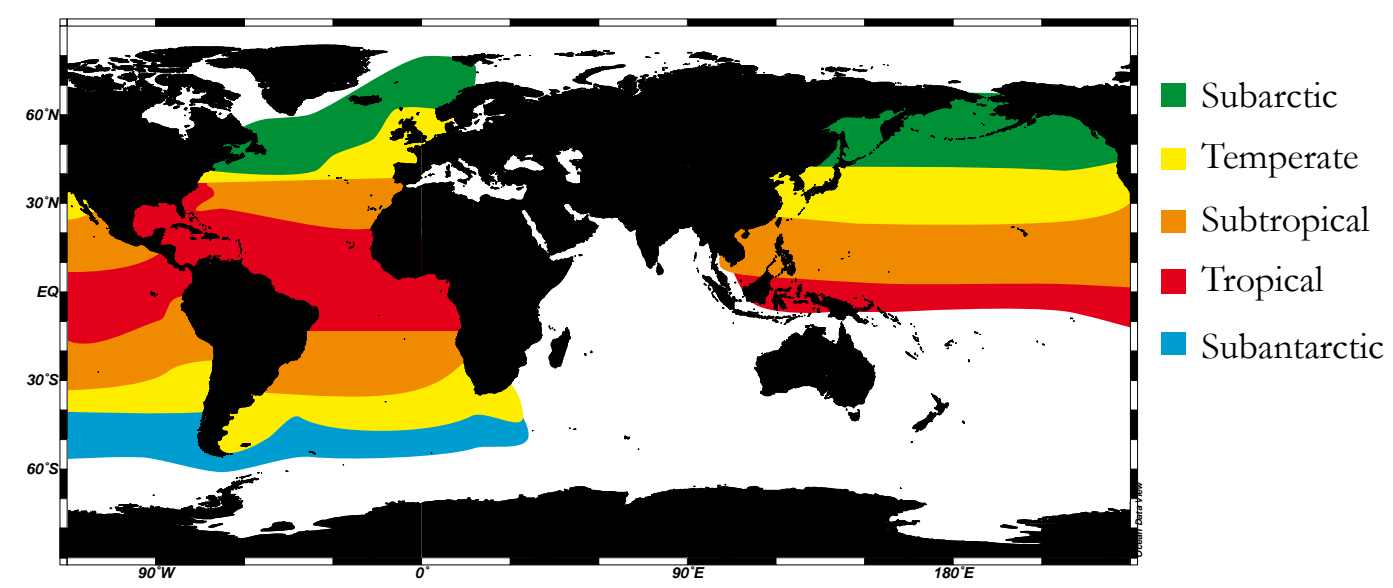

Fig. 4.4. Coccolithophore biogeographic zones. Modified from Flores and Sierro (2007).

\subsection{Sedimentation and preservation in the sediments}

\subsubsection{Sedimentation}

The utility of the coccolithophores for paleoceanographic research is found in the fact that their coccoliths formed by the coccolithophore cell are preserved in deep sea sediments. A good understanding of sedimentation process and the eventual preservation of the coccoliths in the sediments is crucial for reliable paleoceanographic interpretations. The small mass (around $8.10^{6} \mu \mathrm{g}$ ) and the large surface area (around 32 $\mu \mathrm{m}^{2}$ ) of the coccolithophore cells implies that if unassisted the settling velocity of the coccolithophores would be extremely slow and the coccoliths would completely dissolve before reaching the sea-floor (Honjo, 1975). Laboratory experiments and sediment-trap studies have revealed that the vast majority of 
coccolithophores descend rapidly in relatively large aggregate particles (Steinmetz, 1994 and references therein). The most commonly recognized types are fecal pellets and marine snow.

Since coccolithophores are on the base of the food chain, it is very likely that they are consumed before they can complete their life cycle. After consumption, zooplankton produces fecal pellets, containing coccoliths. It has been proved that even the most delicate microstructure of a coccolith can survive a copepod digestion (Roth et al., 1975). One single pellet can contain up to 100000 coccoliths and the pellet is surrounded by a membrane that is believed to protect the coccoliths. The estimated settling velocity is of $200 \mathrm{~m} /$ day. These fecal pellets can settle on themselves or can be integrated in larger aggregates called marine snow. These larger aggregates have a settling velocity of $100 \mathrm{~m} /$ day and can carry up to 2000 fecal pellets. Marine snow is the most important transport mechanism is the deep ocean, while fecal pellets predominate in shallow waters.

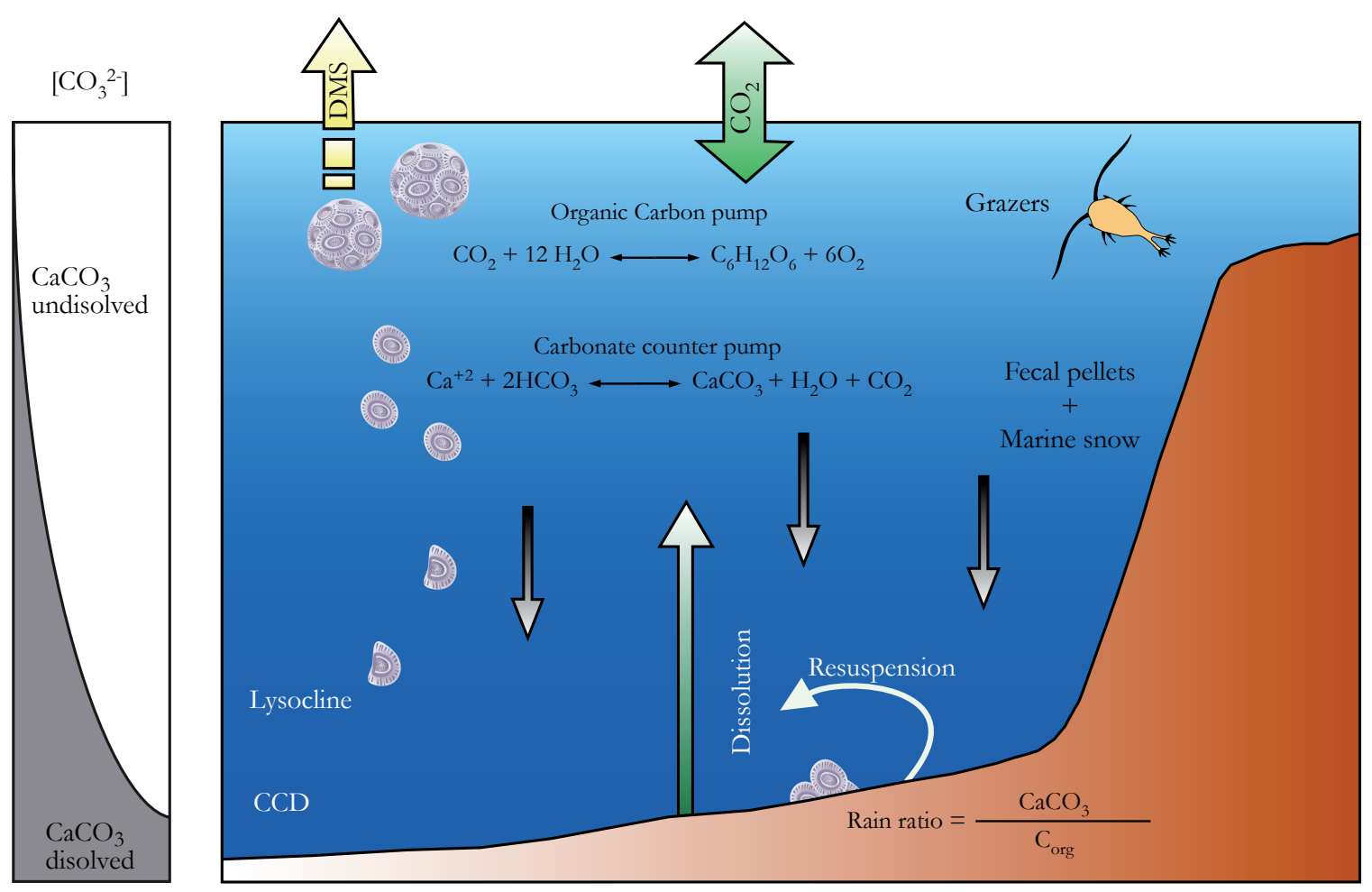

Fig. 4.5. Sedimentation and dissolution processes during sinking of coccolithophores. Modified from Flores and Sierro (2007).

\subsubsection{Dissolution}

During sinking, mostly by means of fecal pellets or marine snow, the $\mathrm{CaCO}_{3}$ molecules of coccoliths interact with the surrounding sea water. More precisely, the $\mathrm{CaCO}_{3}$ molecules will react with the $\mathrm{CO}_{2}$ molecules present in the surrounding water leading to the dissolution of $\mathrm{CaCO}_{3}$ molecules (Fig. 4.5). With increasing depths, dissolution continues. The dissolution rate depends on the time of exposure (sedimentation rate) and the characteristics of the surrounding sea-water (mainly $\mathrm{CO}_{2}$ concentration). In the Southern Ocean, for example, the $\mathrm{AABW}$ has a high $\mathrm{CO}_{2}$ content and thus will enhance the carbonate dissolution. NADW on the contrary has a low $\mathrm{CO}_{2}$ content and will allow better carbonate preservation. At a certain depth, the $\mathrm{CaCO}_{3}$ dissolution reaches a point where it compensates the $\mathrm{CaCO}_{3}$ accumulation. Below this depth, the carbonate 
compensation depth (CCD), all the $\mathrm{CaCO}_{3}$ is dissolved and the net carbonate accumulation is zero. The calcium carbonate compensation depth beneath the temperate and tropical Atlantic is approximately 5000 $\mathrm{m}$ deep, while in the Pacific, it is shallower, about 4200-4000 m, except beneath the equatorial upwelling zone, where the CCD is about $5000 \mathrm{~m}$. The CCD is relatively shallow in high latitudes.

Once a coccolith reaches the ocean floor it is subjected to various processes that will affect the eventual state of preservation in the sediment. First, resuspension of surface sediments may project the coccoliths back into the ocean, where they interact again with the sea-water. Second, several physical, chemical and biological processes act on the particles immediately upon their arrival on the sea floor. All these processes together are called diagenesis. Important processes in the early stages of the diagenesis are: depositional burial, compaction, water flow, benthic boundary diffusion, bioturbation, transfer across the sedimentwater interface, equilibrium processes, microbial reactions, homogeneous (single-phase) reactions, and precipitation and dissolution.

\subsection{Coccolithophore taxonomy and ecological affinities}

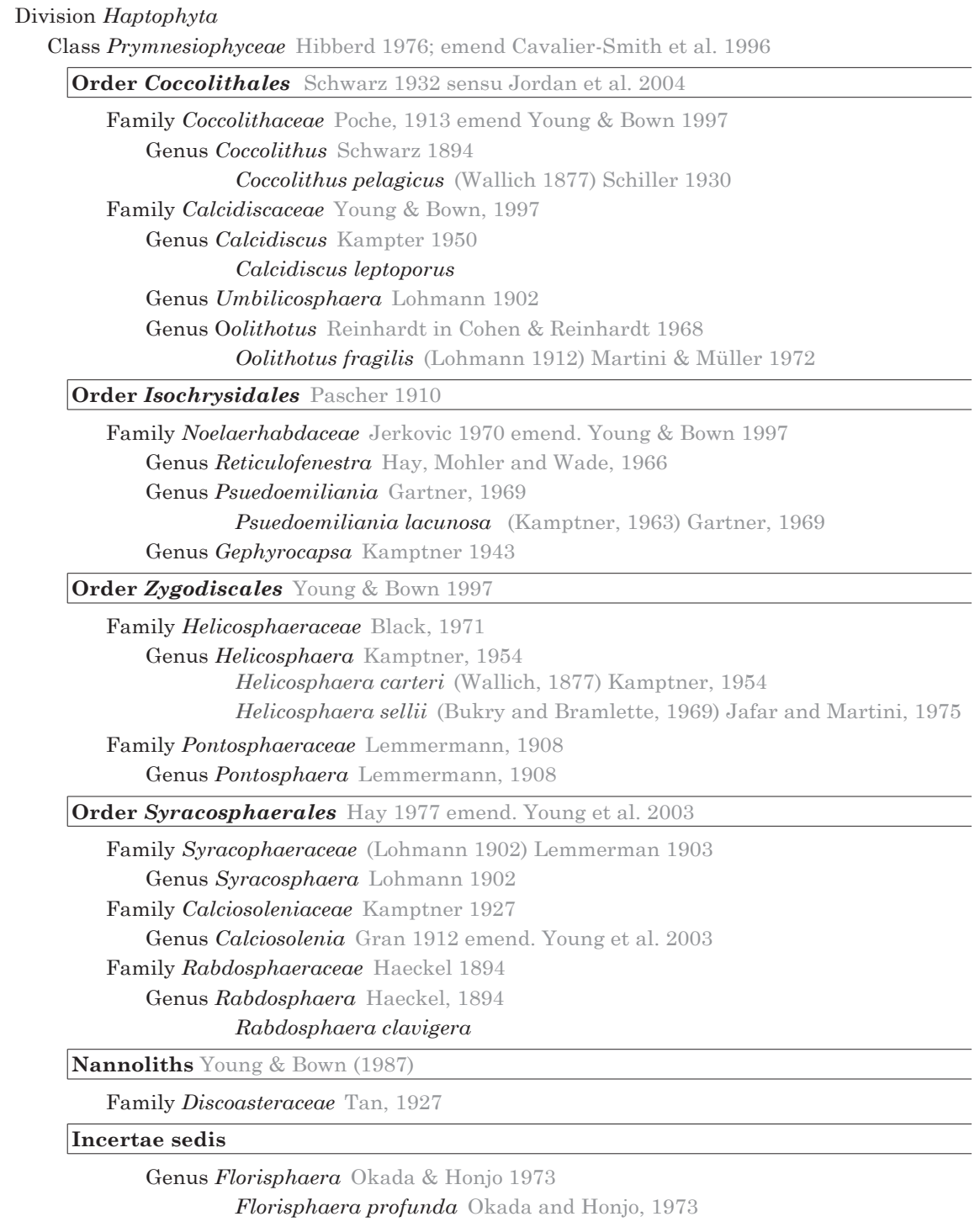

Fig. 4.6. Overview of the coccolithophore systematics used in this study. We used the taxonomic divisions of http:// nannotax.org. 
Accurate taxonomy is essential for a correct interpretation of the preserved nannofossil record. Therefore, a summary of the taxonomy and the ecological affinities of the most important taxa is provided. For this study we used the taxonomic scheme published by the nannotax organization. (Fig. 4.6).

\subsubsection{Coccolithus pelagicus}
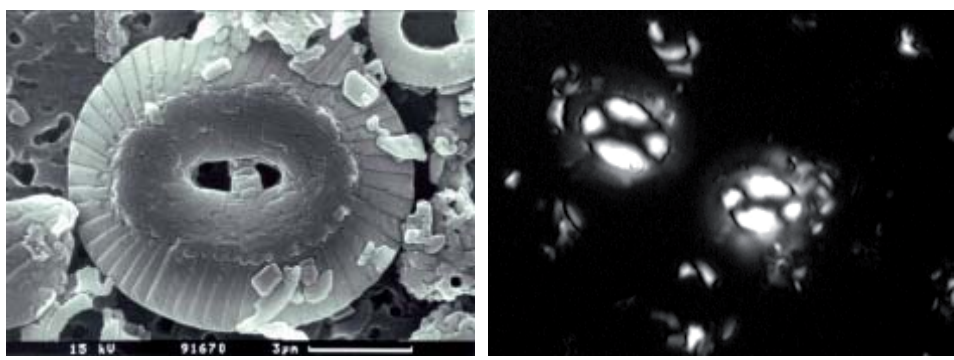

Fig. 4.7. Coccolithus pelagicus. View under the SEM (left) and under the LM (right).

Coccolithus pelagicus is described as an elliptical placolith coccolith with central area open or spanned by a disjunct bar on the proximal surface (Fig. 4.7). This species is very long ranging species (from the Paleocene up to recent) and forms with well-developed bridges only occur in the Late Pliocene and Quaternary.

Recently, Geisen et al. (2002) presented life cycle evidences for the existence of two extant subspecies of $C$. pelagicus: C. pelagicus subsp. pelagicus (the subarctic form) and C. pelagicus subsp. braarudii (the temperate form). Sáez et al. (2003) confirmed genetic differences between the two subspecies. In the light microscope (LM), the subspecies can be distinguished by the length of their placoliths (Baumann, 1995; Parente et al., 2004): (i) the small morphotype $(6-10 \mu \mathrm{m})$ is equivalent to $C$. pelagicus subsp. pelagicus, (ii) the intermediate morphotype $(10-16 \mu \mathrm{m})$ is equivalent to $C$. pelagicus subsp. braarudii and (iii) the large morphotype $(>16 \mu \mathrm{m})$ is descirbed as $C$. pelagicus subsp. Azorinus.

C. pelagicus traditionally has been described as a cold water indicator (Geitzenauer, 1972; Geitzenauer et al., 1976; McIntyre and Bé, 1967; Okada and McIntyre, 1977; Okada and McIntyre, 1979; Raffi and Rio, 1981), having high abundances in periods of $\delta^{18} \mathrm{O}$ enrichments (Beaufort and Aubry, 1990). More recent studies, have associated the intermediate morphotype with high productivity waters (Cachão and Moita, 2000; Fincham and Winter, 1989; Giraudeau and Rogers, 1994) such as the Subtropical Front south of New Zealand (Burns, 1973; Findlay and Giraudeau, 2002).

\subsubsection{Calcidiscus leptoporus}
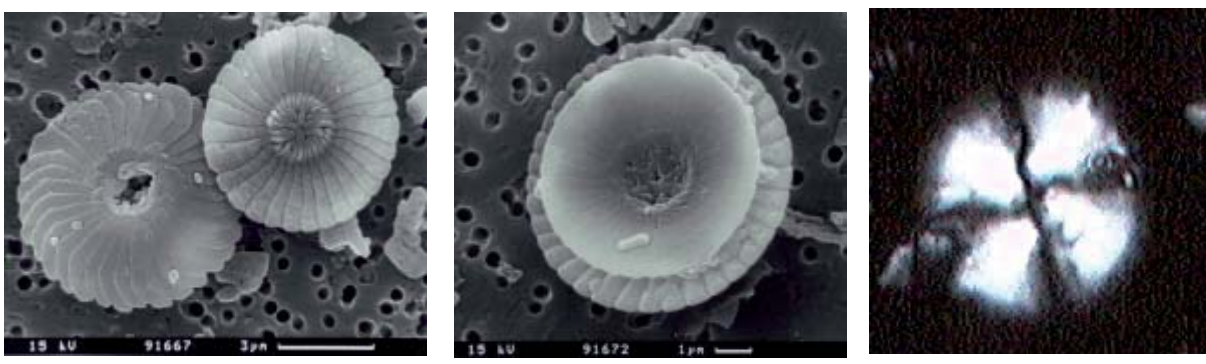

Fig. $\quad$ 4.8. Calcidiscus leptoporus under the SEM(left) and the LM (right).

The genus Calcidiscus is common throughout the Neogene and shows significant variaton in size, number of elements, opening of central area, and structural details. Species concepts have been extensively discussed, most notably by Knappertsbusch (2000). Recent research has lead to a three-fold divsion of the extant

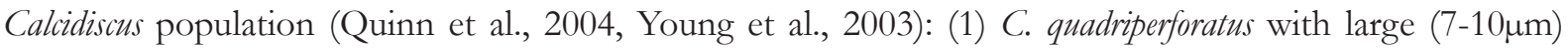
coccoliths, characterized by a zone of obscured sutures around the central area. The haploid phase of this 
species produces septate holococcoliths (formerly classified as Syracolithus quadriperforatus); (2) C. leptoporusintermediate $(5-8 \mu \mathrm{m})$, characterized by continuous sutures. The haploid phase of this species produces planar holococcoliths that formerly where classified as Crystallolithus rigidus and (3) C. leptoporus-small (3$5 \mu \mathrm{m})$ which has kinked sutures. The haploid phase of this last morphotype is not known. For the Pliocene, C. leptoporus is traditionally classified into (1) C. leptoporus; 3-8um circular to sub-circular with closed central area (Fig. 4.8) and (2) C. tropicus \& C .macintyrei; $>11 \mu \mathrm{m}$ circular with open central area. In this studied we used the latter classification. It is not sure how these species relate to the extant species but the degree of variation shown in fossil assemblages suggests that many more species could be recognized.

In the Southern Ocean C. leptoporus has been associated with warmer SST (Findlay and Flores, 2000; Flores et al., 1999; Gard and Crux, 1991; Geitzenauer, 1969; Wells and Okada, 1997). It is negatively correlated with salinity and in less extend positively with nutrients (Boeckel et al., 2006). High percentages are found in the Subantarctic Zone of the Southern Ocean (Boeckel et al., 2006; Eynaud et al., 1999; Findlay and Giraudeau, 2000).

\subsubsection{Reticulofenestra}
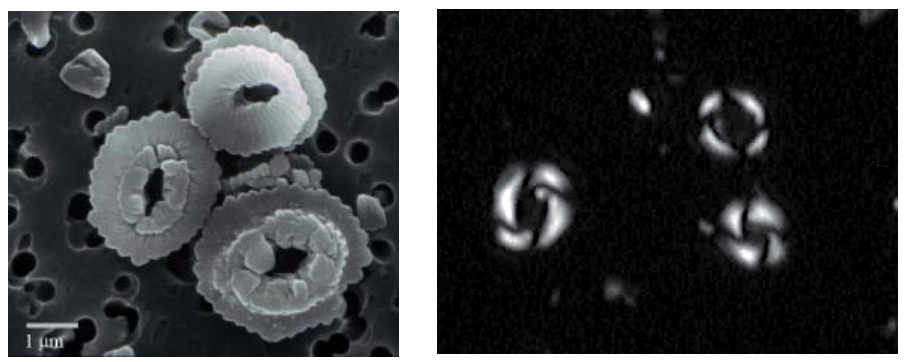

Fig. 4.9. Reticulofenestra spp. $<3 \mu \mathrm{m}$ under the SEM (left) and the LM (right).

During the Plio-Pleistocene, species of the genus Reticulofenestra are very abundant. The species of the genus Reticulofenestra have a very simple morphology, making subdivision into species problematic. For this reason, most authors have been using a taxonomic division primarily based on the size (diameter) of the coccoliths. In the present study the division of Flores et al. (1995) is used (Table 4.1). We will use the term Very Small Reticulofenestra (VSR) for all specimens smaller than $3 \mu \mathrm{m}$ (Fig. 4.9), this group would be equivalent with Reticulofenestra minuta. In our sediments, this group represent the vast majority of the genus Reticulofenestra. Small Reticulofenestra (SR) are all specimens between 3 and $5 \mu \mathrm{m}$. This group includes Reticulofenestra producta,

Taxonomy for the genus Reticulofenestra

\begin{tabular}{|c|c|c|c|}
\hline SIZE & SHAPE & NAME & EQUIVALENT SPECIES \\
\hline \multirow{2}{*}{$\leq 3 \mu \mathrm{m}$} & SUBCIRCULAR & \multirow{2}{*}{$\begin{array}{l}\text { Very Small Reticulofenestrids } \\
\text { (VSR) }\end{array}$} & Reticulofenestra minuta; Dictyococcites productus \\
\hline & CIRCULAR & & Pseudoemiliania lacunosa \\
\hline \multirow[t]{2}{*}{ 3-5 $\mu \mathrm{m}$} & SUBCIRCULAR & $\begin{array}{l}\text { Small Reticulofenestrids } \\
\qquad(\mathrm{SR})\end{array}$ & $\begin{array}{c}\text { R. haqii ; R. minutula; R. perplexa }=D \text {. antarcticus ; } \\
\text { D. productus }\end{array}$ \\
\hline & CIRCULAR & \multicolumn{2}{|r|}{ Pseudoemiliania lacunosa } \\
\hline \multirow[t]{2}{*}{ 5-7 $\mu \mathrm{m}$} & SUBCIRCULAR & $\begin{array}{l}\text { Medium Reticulofenestrids } \\
\text { (MR) }\end{array}$ & R. haqii ; R. minutula?; R. perplexa $=D$. antarcticus \\
\hline & CIRCULAR & \multicolumn{2}{|r|}{ Pseudoemiliania lacunosa } \\
\hline \multirow{2}{*}{ 6-8 $\mu \mathrm{m}$} & SUBCIRCULAR & \multirow{2}{*}{\multicolumn{2}{|c|}{ Reticulofenestra asanoi }} \\
\hline & CIRCULAR & & \\
\hline$>7 \mu \mathrm{m}$ & SUBCIRCULAR & \multicolumn{2}{|c|}{ Reticulofenestra psuedoumbilicus } \\
\hline
\end{tabular}

Table 4.1. Taxonomic divisions for the genus Reticulofenestra based on Flores et al. (1995). 
Reticulofenestra minutula and Reticulofenestra haqii.

The ecology of these species is poorly understood and this genus is mostly used for biostratigraphic studies. Nevertheless, Aubry (1992) and Flores et al. (1995) interpreted that Reticulofenestra minuta is a hardy, opportunistic taxa with a wide ecological tolerance, capable of flourishing in nutrient rich conditions. This species can withstand intervals of high environmental stress, responding quickly to changes within the environment, tending to dominate in periods where other species can not compete.

\subsubsection{Gephyrocapsa}
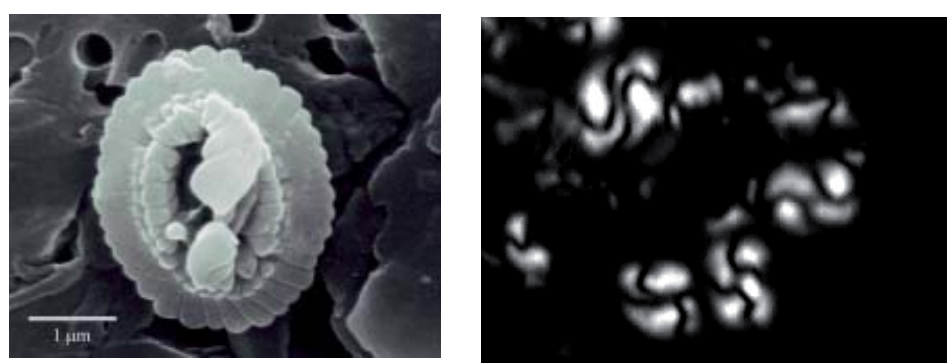

Fig. 4.10. Gephyrocapsa spp. $<3 \mu \mathrm{m}$ under the SEM (left) and the LM (right).

Identification of Gephyrocapsa species under the LM is a difficult issue. Therefore this genus was divided in two size groups: coccoliths smaller than $3 \mu \mathrm{m}$ were grouped as small Gephyrocapsa (SG), as in Flores et al. (1999) (Fig. 4.10). For the late Pliocene this group includes Gephyrocapsa aperta, Gephyrocapsa sinuosa and Gephyrocapsa protohuxleyi. Specimens larger than $3 \mu \mathrm{m}$ will be named Medium Gephyrocapsa (MG). This group is equivalente with Gephyrocapsa margerelii (Samtleben, 1980). For the Pleistocene sediments, we have identified G. omega and Large Gephyrocapsa (>5.5 $\mu \mathrm{m})$.

Few studies have been made about the ecology of these groups during the Pliocene. For the Holocene, Bollman (1997) associated his Gephyrocapsa minute morphotype (equivalent to our SG) with tropical and subtropical neritic regions, while Wells and Okada (1997) used this group as an indicator for upwelling conditions. Gephyrocapsa caribbeanica and Gephyrocapsa margerelii are included in Gephyrocapsa oligotrophic morphotype of Bollman (1997) and their maximum abundances are documented in oligotrophic subtropical regions with a SST between $22^{\circ} \mathrm{C}$ and $25^{\circ} \mathrm{C}$. The Gephyrocapsa species have also been used to infer glacialinterglacial dynamics, with SG being more abundant during interglacial periods and G. caribbeanica during glacial periods (Baumann and Freitag, 2004; Flores et al., 1999).

\subsubsection{Helicosphaerea carteri}

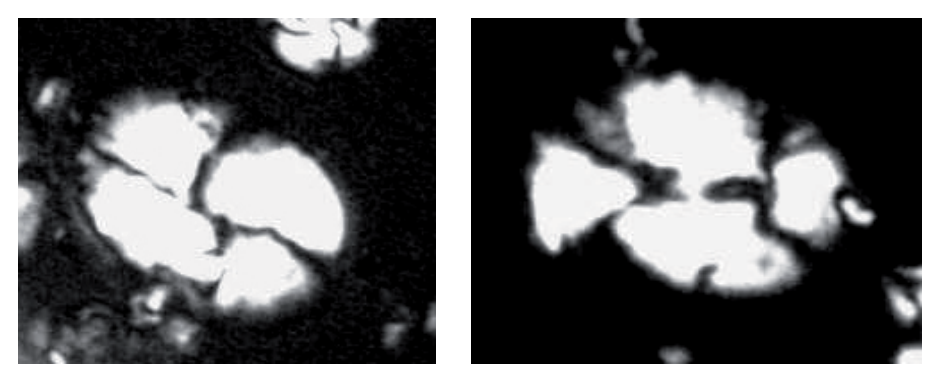

Fig. 4.11. H. carteri under the LM.

H. carteri has medium to large size coccoliths with a flange that ends in a wing and two pores in central-area (Fig. 4.11). It is the most common Helicosphaera species and ranges from NN1 to NN21. Traditionally, $H$. carteri has been associated with warm waters (Brand, 1994; Gard and Backman, 1990; McIntyre and Bé, 1967). Despite its common occurrence, little detailed information is available about its behavior at high latitudes. 
In the Southern Ocean, $H$. carteri has been related to warm subtropical-like waters (Fenner and Di Stefano, 2004; Findlay and Flores, 2000). Other authors believe that this species is affected by nutrient levels, being more abundant waters with a moderately elevated nutrient conditions (Baumann, 2005). This interpretation is supported by the observation of a parallel distribution between $C$. leptoporus and H. carteri with the 'small' Noelaerhabdaceae (Flores et al., 2003). H. carteri has also been used to indicate the proximity of the Polar (Eynaud et al., 1999) and the Subantarctic Front (Eynaud et al., 1999; Flores and Sierro, 2007).

\subsubsection{Helicosphaerea sellii}

H. sellii has the same general morphology as $H$. carteri but $H$. sellii has larger pores. This species ranges from zone NN12 to NN19. The ecology of this species is only poorly understood and up to now this species is almost exclusively used for biostratigraphic use. Although even for biostratigraphic use, its last occurrence is believed to be diachronous (eg. Backman and Shackleton, 1983; Raffi et al., 1993; Wei, 1993) and recent studies question the utility of this datum (Raffi, 2002).

\subsubsection{Subtropical Taxa}
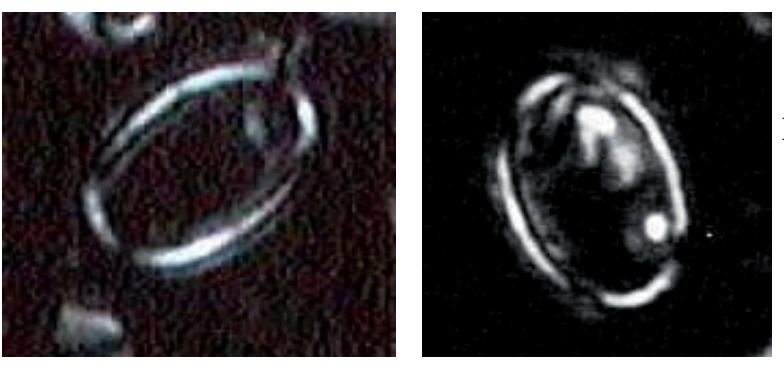

Fig. 4.12. Discoliths under the LM.

The occurrence of subtropical taxa was very low at our study sites. For the interpretation of our nannofossil record all subtropical taxa were grouped together and used as an indicator for relatively hiher SST. Subtropical taxa include: Pontosphaera spp., Syracosphaera spp., Rabdosphaera clavigera, Umbilicosphaera spp. and Calciosolena sp. The central area of the liths of the genus Pontosphaera and Syracosphaera were dissolved in most of the cases and were grouped together as discoliths (Fig. 4.12). 



\section{HAPTER 5: AGE MODEL}

\subsection{ODP site 1090}

5.2. ODP site 1172

5.2.1. Nannofossil biostratigraphy

5.2.2. Magnetostratigraphy

5.2.3. Oxygen isotope stratigraphy 



\section{CHAPTER 5: AGE MODEL}

\subsection{ODP site 1090}

The age model of ODP site 1090 was based on the oxygen isotope stratigraphy published by Venz \& Hodell (2002). These authors performed isotopic analysis on planktonic (Globigerina bulloides) and benthic (Cibicidoides wuellerstorfi) foraminifers. The age-depth relation resulted in an average sedimentation rate of 1.51 $\mathrm{cm} / \mathrm{ka}$. The interval analyzed during this study ranges from 3.15 to $1.8 \mathrm{Ma}$ and has several discontinuities (Fig. 5.1) or hiatus listed in Table 5.1. Despite these hiatus, the record has enough resolution to perform our analysis.

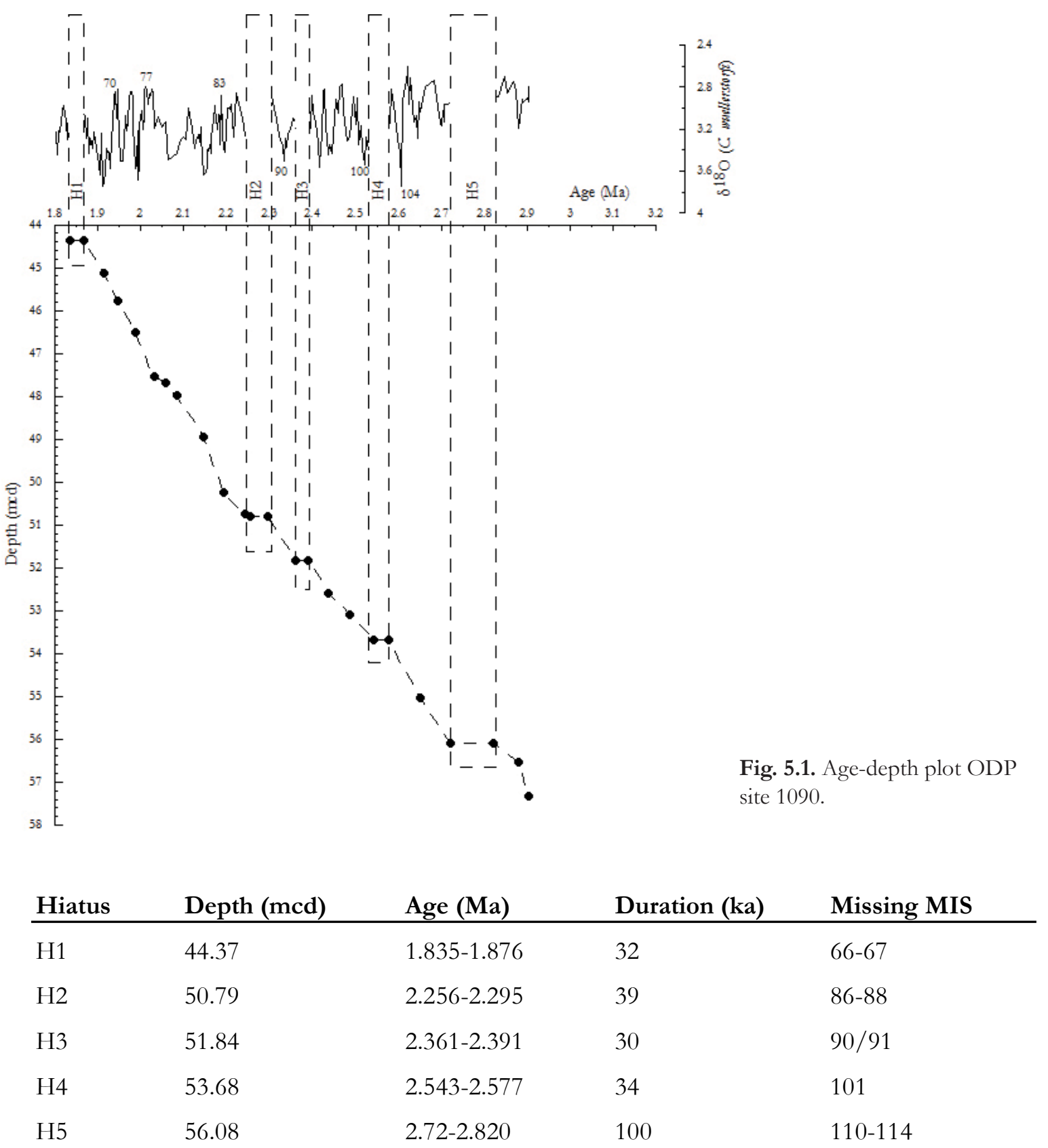

Table 5.1. Hiatus found in ODP site 1090 (Venz \& Hodell, 2002). 


\subsection{ODP site 1172}

The sample interval chosen for ODP site 1172 was based on the age assignments of the paleomagnetic reversals published by Stickley et al. (2004). Following these authors, the sampled section (18.05-47.42 mcd) was supposed to range from $\sim 1.69 \mathrm{Ma}$ to $\sim 3.5 \mathrm{Ma}$. Nevertheless, analysis of the calcareous nannofossil assemblage revealed much younger ages at the top of the interval. The calcareous nannofossil biostratigraphy and the benthic $\delta^{18} \mathrm{O}$ record contradict the interpretation of the paleomagnetic reversals of Stickley et al. (2004). We reinterpreted the paleomagnetism of Stickley et al. (2004) and constructed a new age-model based on the nannofossil biostratigraphy and our benthic $\delta^{18} \mathrm{O}$ record.

\subsubsection{Calcareous nannofossil biostratigraphy}

The high nannofossil abundance in the sediments enabled us to identify a series of biostratigraphic events that are of great importance to construct a solid age model (Fig. 5.2). The bottom of the biostratigraphic range of the studied section is situated after the Last Occurrence (LO) of Sphenolithus spp. and Reticulofenestra psuedoumbilicus and the top belongs to zone NN 19 following the zonation of Martini (1971). The identified events are listed from bottom to top and are resumed in Table 5.2 (p. 49). The discussion of the LO of Helicosphaera sellii is not included in the present study, because the biostratigraphic and biochronologic value of this biohorizon has been widely discussed in previous articles (eg. Backman and Shackleton, 1983; Raffi et al., 1993; Wei, 1993) that evidenced its remarkable diachrony (Raffi, 2002).

\section{Last Occurrence Sphenolithus spp. and Reticulofenestra pseudoumbilicus}

At the bottom of the studied section Sphenolithus spp. and Reticulofenestra psuedoumbilicus were absent, implying that the oldest samples are situated above the LO of S. abies (around 3.66 Ma) and R. psuedoumbilicus (around 3.8 Ma)(Raffi et al., 2006).

\section{Last Occurrence Discoaster surculus}

Discoasterids have very rare abundances in site 1172 and presented a discontinuous record. Based on the record of only very few individuals, the LO of D. surculus was placed at $30.25 \mathrm{mcd}$. For hole 1172 this event is dated $2.35 \mathrm{Ma}$, diachronous with the data of Raffi et al. (2006). These authors have dated this event between 2.54 Ma in the Eastern Mediterranean and 2.49 Ma in the Tropical East Atlantic. This diachronism may be due to the low and discontinuous abundance of this species. This event therefore is classified as less reliable. This datum approximates the limit Plio/Pleistocene following the new time scale.

The limit Early/Late Pleistocene is approximated by the FO of medium Gephyrocapsa and the LO of $C$. macintyrei.

Fig. 5.2. Age model ODP site 1172: The age-depth points were based on: Significant biostratigraphic events, paleomagnetic reversals publishedby Stickley et al. (2004) and oxygen isotope stratigraphy after comparasion with the LR04-stack (Lisiecki \& Raymo, 2005). 


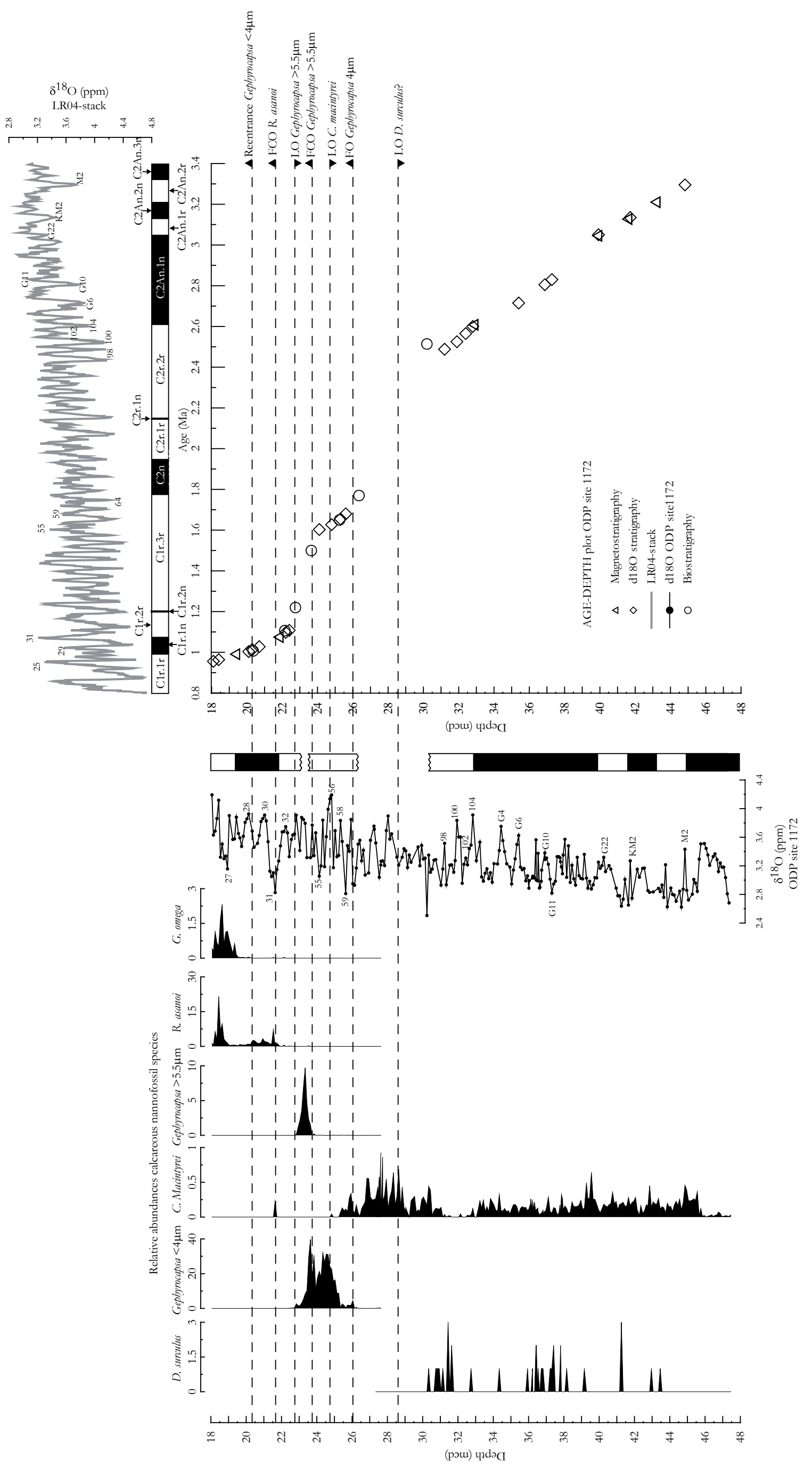




\section{First Occurrence Gephyrocapsa $>4 \mu \mathrm{m}$}

The record of Gephyrocapsa $>4 \mu \mathrm{m}$, including both Gephyrocapsa caribbeanica as Gephyrocapsa oceanica, starts at 26.7 mcd with very low abundances $(<0.02 \%)$. The First Occurrence is detected at $26.0 \mathrm{mcd}$, where the relative abundance is above $1 \%$ (Table 5.2). Following our age model, this event is dated at $1.73 \mathrm{Ma}$. Although Raffi (2002; 1993) described this event as diachronous between low- and mid-latitudes, our datation coincides with the ages from low-latitude environments (Eastern Mediterranean) published by Raffi et al. (2006).

\section{Last Occurrence Calcidiscus macintyrei}

The distribution pattern of C. macintyrei is discontinuous between 25.3 and $24.7 \mathrm{mcd}$ and The LO of $C$. macintyrei is found at $24.75 \mathrm{mcd}$. Some individuals of C. macintyrei have been identified at 21.6 mcd but have been interpreted as reworked. The age assigned to this event, $1.624 \mathrm{Ma}$ is within the range of Raffi et al. (2006) (Table 5.2).

\section{First Occurrence Gephyrocapsa $>5.5 \mu \mathrm{m}$}

A difference was made between the FO and the First Common Occurrence (FCO) of Gephyrocapsa $>5.5 \mu \mathrm{m}$, as in Raffi et al. (2006). The FO is identified at $24.15 \mathrm{mcd}$ and dated at $1.59 \mathrm{Ma}$, in agreement with Raffi et al. (2006). Gephyrocapsa $>5.5 \mu \mathrm{m}$ has a continuous record above $23.6 \mathrm{mcd}$ and its FCO is identified at 23.65 mcd corresponding with an age of $1.50 \mathrm{Ma}$. This is slightly diachronous with the data of ODP legs 111 and 138 which identified this event at $1.46 \mathrm{Ma}$ (Raffi et al., 2006 and references there in). Raffi (2002) described this event as slightly diachronous and with a low degree of reliability.

\section{Last Occurrence Gephyrocapsa $>5.5 \mu \mathrm{m}$ and the temporal disappearance of Gephyrocapsa $>4 \mu \mathrm{m}$.}

The abundance pattern of Gephyrocapsa $>5.5 \mu \mathrm{m}$ shows a rapid decline after $23.3 \mathrm{mcd}$ and the LO of this species is placed at $22.75 \mathrm{mcd}$, when Gephyrocapsa $>5.5 \mu \mathrm{m}$ completely disappears at hole $1172 \mathrm{~A}$. This event coincides with the temporal disappearance of Gephyrocapsa $>4 \mu \mathrm{m}$, identified at the point where the abundance drops below $0.05 \%$. The age estimated for these events is $1.217( \pm 0.016) \mathrm{Ma}$. The LO of Gephyrocapsa $>5.5 \mu \mathrm{m}$ is established by Raffi et al. (2006) between 1.24 and $1.255 \mathrm{Ma}, \pm 0.04 \mathrm{Ma}$ earlier than at hole 1172A. This event has also been found slightly diachronous (20 ka later than standard calibration) in site 607. The slight diachrony may be explained by the influence factors that control the distribution of large gephyrocapsids in their uppermost range in different locations (Raffi, 2002).

\section{First Occurrence and First Common Occurrence Reticulofenestra asanoi}

$\mathrm{R}$ asanoi is rare and discontinuous at the beginning of its distribution and therefore a separation was made between the absolute FO and the FCO. The FO is estimated at $22.95 \mathrm{mcd}$ or $1.28 \mathrm{Ma}$. The more commonly used FCO is identified where R. asanoi is consistently present, corresponding with a depth of 21.65 mcd and an age of $1.073 \mathrm{Ma}$; 0.005 Ma later than the datations of Raffi et al. (2006). The FCO of R. asanoi has been used to identify MIS 31 .

\section{Reentrance Gephyrocapsa $>4 \mu \mathrm{m}$ and FO Gephyrocapsa omega}

The reentrance of Gephyrocapsa $>4 \mu \mathrm{m}$ is synchronous with the FO of G. omega/paralela and occur at 20.35 mcd. Both taxa are rare at the start of their distribution: G. omega and Gephyrocapsa $>4 \mu \mathrm{m}$ (here represented 


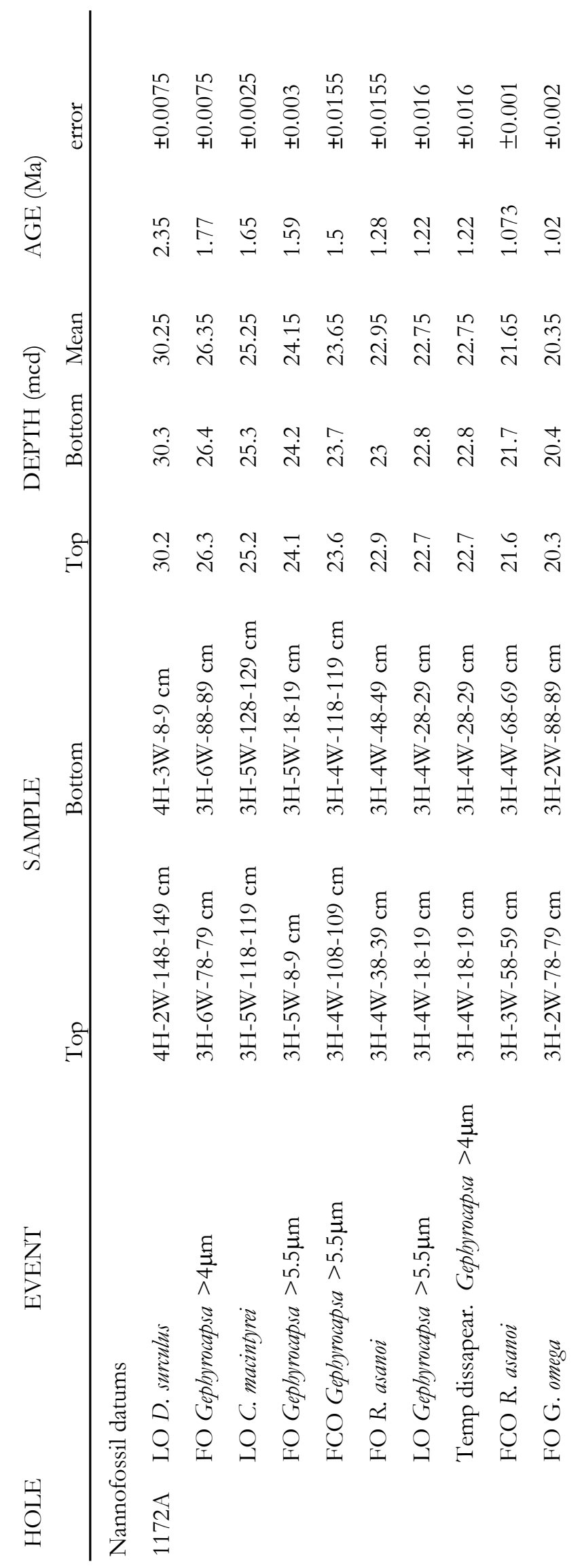

Table 5.2. List of biostratigraphic events identified at ODP site 1172. 
solely by G. oceanica) have abundances below $0.05 \%$ until 19.52 mcd. Following our age model, these events are dated at $1.016 \mathrm{Ma}$, identifying MIS 27. The reappearance of medium-sized Gephyrocapsa is known to be consistently diachronous at different latitudes, between MIS 29 and 25, and is considered as a possible migratory event from low to mid-high latitudes (Flores et al., 1999; Raffi, 2002; Raffi et al., 1993; Wei, 1993). In high to mid-latitude sections of the Atlantic (Raffi et al., 1993; Wei, 1993) and the eastern Mediterranean (Castradori, 1993), the reentrance of Gephyrocapsa $>4 \mu \mathrm{m}$ was recorded in the interval ranging from MIS 27 to MIS 25 , as in site 1172 .

\subsubsection{Magnetostratigraphy}

The major paleomagnetic chrons and subchrons were identified by Stickley et al. (2004). The nannofossil biostratigraphy revealed that the chron between 21.78 and 19.32, identified by Stickley et al. (2004) as C2n (1.78-1.97 Ma), corresponds with chron C1r.1n (0.99-1.07 Ma). Two well established biostratigraphic evidences support this reinterpretation: (i) The FCO R. asanoi marks MIS 31; (ii) the FO of G. omegal reentrance of Gephyrocapsa $>4 \mu \mathrm{m}$ assures us that the section reaches up to MIS 27 . The occurrence of discoasterids is low and discontinuous but the approximation of the LO D. surculus enabled us to verify the correct identification of Stickley et al. (2004) of the top of chron C2An.1n. Isotopic stage M2, identified in the benthic $\delta^{18} \mathrm{O}$ record of site 1172, affirms the identification of the top of C2An.3n of Stickley et al. (2004). This new interpretation of the magnetic polarity, shown in Fig. 5.2, reveals a discontinuous sediment record since chron $\mathrm{C} 2 \mathrm{n}$ is not identified at site 1172 .

\subsubsection{Oxygen isotope stratigraphy}

The chronologies of site 1172 were derived by correlation of the benthic foraminiferal oxygen isotopic signal with the benthic LR04-stack (Lisiecki and Raymo, 2005) using the program Analyseries (Paillard et

\begin{tabular}{llllll}
$\begin{array}{l}\text { Age } \\
\text { (Ma) }\end{array}$ & $\begin{array}{l}\text { Depth } \\
(\mathbf{m c d})\end{array}$ & $\begin{array}{l}\text { Marine Isotope } \\
\text { Stage (MIS) }\end{array}$ & $\begin{array}{l}\text { Age } \\
(\mathbf{M a})\end{array}$ & $\begin{array}{l}\text { Depth } \\
(\mathbf{m c d})\end{array}$ & $\begin{array}{l}\text { Marine Isotope } \\
\text { Stage (MIS) }\end{array}$ \\
\hline 0.96 & 18.1 & MIS 25 & 2.488 & 31.2 & MIS 98 \\
0.96 & 18.4 & MIS 26 & 2.525 & 31.9 & MIS 100 \\
1.00 & 20.1 & MIS 28 & 2.565 & 32.4 & MIS 102 \\
1.01 & 20.3 & MIS 29 & 2.6 & 32.8 & MIS 104 \\
1.03 & 20.7 & MIS 29 & 2.715 & 35.4 & MIS G6 \\
1.10 & 22.2 & MIS 32 & 2.805 & 36.88 & MIS G10 \\
1.11 & 22.4 & MIS 33 & 2.83 & 37.28 & MIS G11 \\
1.60 & 24.1 & MIS 55 & 3.05 & 39.92 & MIS G22 \\
1.63 & 24.8 & MIS 56 & 3.135 & 41.72 & MIS KM2 \\
1.66 & 25.3 & MIS 58 & 3.295 & 44.82 & MIS M2 \\
1.68 & 25.6 & MIS 59 & & &
\end{tabular}

Table 5.3. Age-depth points chosen for ODP stie 1172 
al., 1996). Based on the $\delta^{18} \mathrm{O}$ curve, the nannofossil biostratigraphy and the magnetostratigraphy, 21 age control points were identified and have been translated into absolute ages (Table 5.3). The estimated average sedimentation rate based on the age-depth relationship is $2.55 \mathrm{~cm} / \mathrm{ka}$, varying from $1.13 \mathrm{~cm} / \mathrm{ka}$ to 6.67 $\mathrm{cm} / \mathrm{ka}$. The correlation between our $\delta^{18} \mathrm{O}$ record and the LR04-stack is good between 3.45 and $2.45 \mathrm{Ma}$, although the resolution of our record did not allow the identification of all individual marine isotopic stages. The lack of a good $\delta^{18} \mathrm{O}$ correlation, the absence of biostratigraphic events and the fact that the $\mathrm{C} 2 \mathrm{n}$ chron is not identified made age estimations of the section between $31 \mathrm{mcd}$ and $25.9 \mathrm{mcd}$ impossible. The data of this interval, spanning from MIS 97 to MIS 61, have not been used for further analyses. Good correlation was found again from 1.75 to $1.55 \mathrm{Ma}$ and MIS 60 to 54 were identified. The FO (MIS 54-56) and LO (MIS 38) of Gephyrocapsa $>5.5 \mu \mathrm{m}$ are recorded in $1.45 \mathrm{~m}$. This, and the lack of $\delta^{18} \mathrm{O}$ correlation, suggests another hiatus in our record: MIS 54-MIS 38 have not been identified (Fig. 5.2). The top section, 25.9- 23.9 mcd, had a good $\delta^{18} \mathrm{O}$ correlation and permitted a successful identification of MIS 26 to MIS 31 (0.95- $1.15 \mathrm{Ma}$ ). 



\section{ChAPTER 6: CARBONATE DISSOLUTION IN ODP SITE 1090-COMPARISON OF DIFFERENT DISSOLUTION PROXIES}

6.1. Introduction

6.2. Different methods

6.2.1. Number and size of fragments

6.2.2. Fragmentation ratios based on single species

6.3. Comparison and evaluation of the different proxies

6.4. Conclusions 



\section{CHAPTER 6:CARBONATE DISSOLUTION IN ODP SITE 1090- COMPARISON OF DIFFERENT DISSOLUTION PROXIES}

\subsection{Introduction}

The majority of the carbonate (four fifths following Broecker, 1974) that is fixed by coccolithophores at the surface is dissolved in the water column. In order to make accurate paleoecological or paleoclimatic interpretations, it is necessary to differentiate between faunal changes that result from climatic or related environmental changes and those superimposed by dissolution. The alteration of calcareous microfaunal assemblages by calcium carbonate dissolution has been widely investigated. Yet, most work is focused on foraminifers, mostly due to the fact that coccolithophores are really small, have delicate ultrastructures and present complex sedimentation processes. Nevertheless, in deep water calcareous nannoplankton generally are more resistant to solution than planktonic foraminifera (Hay, 1970) probably because of an organic coating which protects coccoliths (Roth and Thierstein, 1972) and/or accelerated transport via sinking feacal pellets (Honjo, 1975). Under the light microscope, the degree of dissolution can be determined visually and traditionally is expressed semiquantitatively (Gersonde et al., 1999a; Roth and Thierstein, 1972) or quantitatively by the use of dissolution rankings and indices (Dittert et al., 1999; Matsuoka, 1990). Despite the hard effort, quantitative reconstruction of past carbonate dissolution remains difficult and most of the criteria used to judge the state of preservation of the different calcite structures remain qualitative.

The calcareous nannofossils of the Pliocene section recovered in ODP hole 1090 present an uniformly moderate preservation following the traditionally established ranking of Wei et al. (1990)

$$
\begin{aligned}
\mathrm{G}= & \text { Good: little or no evidence of dissolution, delicate parts are preserved } \\
\mathrm{M}= & \text { Moderate: dissolution (etching) and/or recrystallization (overgrowth) of individual } \\
& \text { specimens are apparent; identification of species is generally not impaired } \\
\mathrm{P}= & \text { Poor: individual specimens exhibit considerable dissolution and/or recrystallization; } \\
& \text { identification of some species is not possible }
\end{aligned}
$$

\footnotetext{
Most samples show signs of slight etching and moderate overgrowth. Etching has removed delicate features from some species, for example the central area of Pontosphaera spp. and Syracosphaera spp but this didn't hamper identification of most of the coccoliths up to species level. Despite the uniformly moderate preservation of the calcareous nannofossils, some samples exhibited a large amount of coccolith fragments. Studies with foraminifera have suggested that the fragmentation of their shells is directly related to dissolution (Berger, 1970). In this sense, we attempted to establish some criteria to compare the degree of coccolith fragmentation in the different samples. To do so we calculated, and compared, different dissolution proxies. This is of great interest not only to validate the nannofossil record as a paleoclimate proxy but also because the degree of carbonate dissolution gives us infromation about the deep water circulation and the bottom water chemistry, as will be discussed in Chapter 7.
} 


\subsection{Different methods}

\subsubsection{Number and size of fragments}

In order to make an estimation of the number $(\mathrm{NF})$ and the size (SF) of the coccoliths fragments of our samples, different categories were established. Since it was not feasible to count all the fragments under the LM, the different categories were defined depending on a general observation on the relation of "area covered with fragments" versus "area covered with coccoliths" (Table 6.1). To evaluate the size of the fragments, 4 categories were made according to the relative abundance of small $(<3 \mu \mathrm{m})$ versus large $(>3 \mu \mathrm{m})$ fragments (Table 6.1). This procedure is very little time-consuming and was carried out during counting. We observed several fields of view and every sample was given two numbers: (i) a number from 1-5 to estimate the number of fragments and (ii) a number from 1-4 to estimate the size of the fragments.

\section{Estimation of the number of fragments}

Ranking

1 Very low fragmentation

2 Low fragmentation

3 Intermediate fragmentation

4 High fragmentation

$5 \quad$ Very high fragmentation

\section{Criteria}

Area covered with fragments/area covered with coccoliths $<<1$

Area covered with fragments/area covered with coccoliths $<1$

Area covered with fragments/area covered with coccoliths $=1$

Area covered with fragments/area covered with coccoliths $>1$

Area covered with fragments/area covered with coccoliths $>>1$

\section{Estimation of the size of the fragments}

\begin{tabular}{lll}
\multicolumn{1}{c}{ Ranking } & Criteria \\
\hline $\mathbf{1}$ & Fine fragments & Samples are dominated with very small fragments $(<2 \mu \mathrm{m})$ \\
$\mathbf{2}$ & Small fragments & Large fragments $/$ small fragments $<<1$ \\
$\mathbf{3}$ & Intermediate fragments & Large fragments $/$ small fragments $=1$ \\
$\mathbf{4}$ & Large fragments & Large fragments $/$ small fragments $>>1$
\end{tabular}

Table 6.1. Established ranking to estimate the number, and the size, of coccolith fragments in each field of view.

\subsubsection{Fragmentation ratio based on single species}

We have studied the fragmentation ratio of two different species: Calcidiscus leptoporus and Coccolithus pelagicus. The fragmentation ratio of C. leptoporus is based on a the method of Matsuoka (1990), which has been used during more recent studies (Blaj et al., 2009; Bolton et al., 2010b; Findlay and Giraudeau, 2002). In the case of C. leptoporus, dissolution along the suture lines of the central column leads to the rupture of the both shields and heavily dissolved samples are dominated by distal shields (Schneidermann, 1977). The fragmentation ratio of this species is based on the relation between complete individuals (CI) and distal shields (DS). Random visual fields of homogeneously distributed samples were observed, counting CI and DS until a number of $50 \mathrm{CI}$ was reached (Fig. 6.1). Instead of determining the \% of complete individuals as Matsouka (1990), we used the following equation:

$$
D L=D S /(D S+C I)
$$




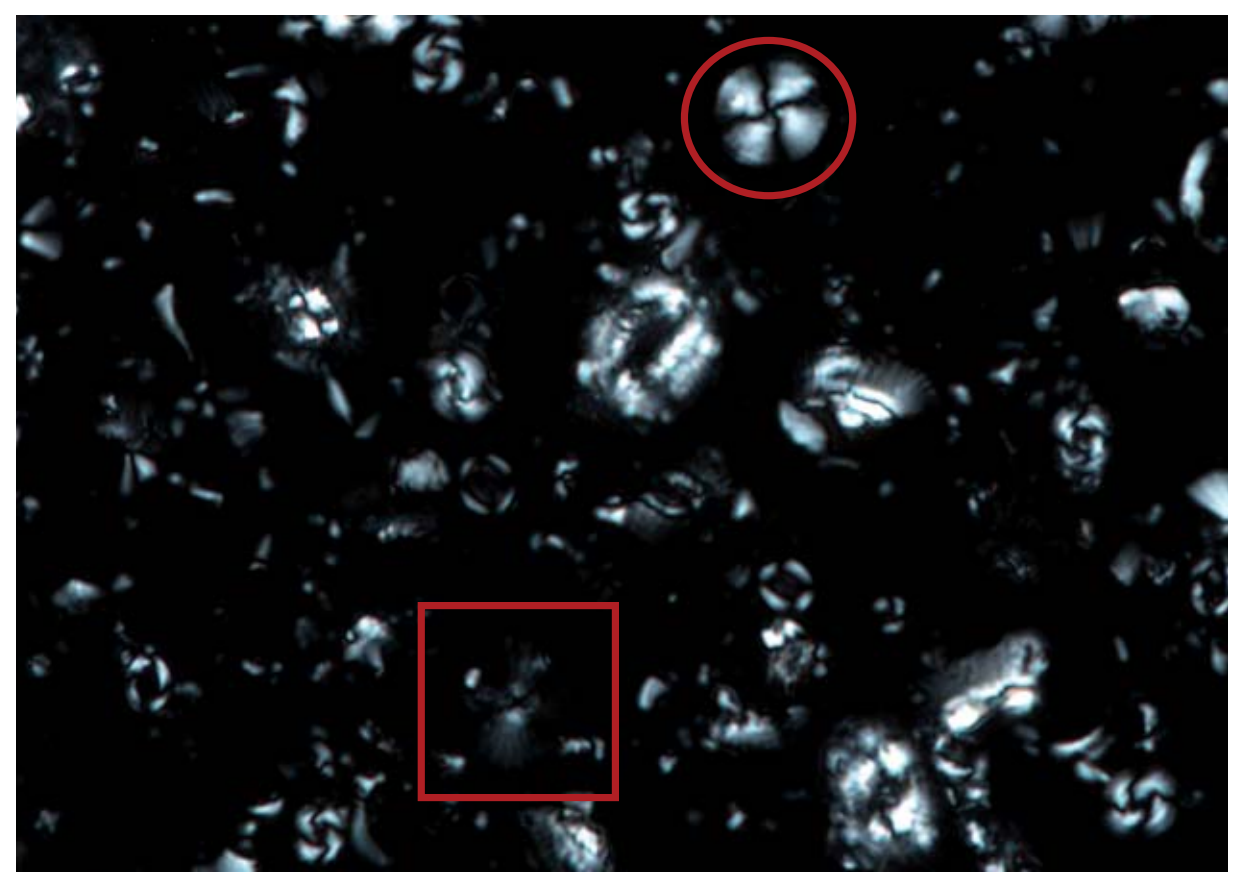

Fig. 6.1. Random field of view of ODP site 1090. To estimate the fragmentation of $C$. leptoporus we calculated the ratio between complete individuals (red circle) and distal shields (red rectangle).

The high abundances of $C$. pelagicus in our sediment record and the observation of fragments that obviously belonged to this species allowed us to calculate an additional fragmentation ratio based on this species. We analyzed a limited area and counted the $\mathrm{CI}$ and the fragments $(\mathrm{F})$ of this species until a total number of 50 CI was reached (Fig. 6.2). Analogous with DL, DP was based on the relation between the CI and F using the equation:

$$
D P=F /(F+C I) .
$$

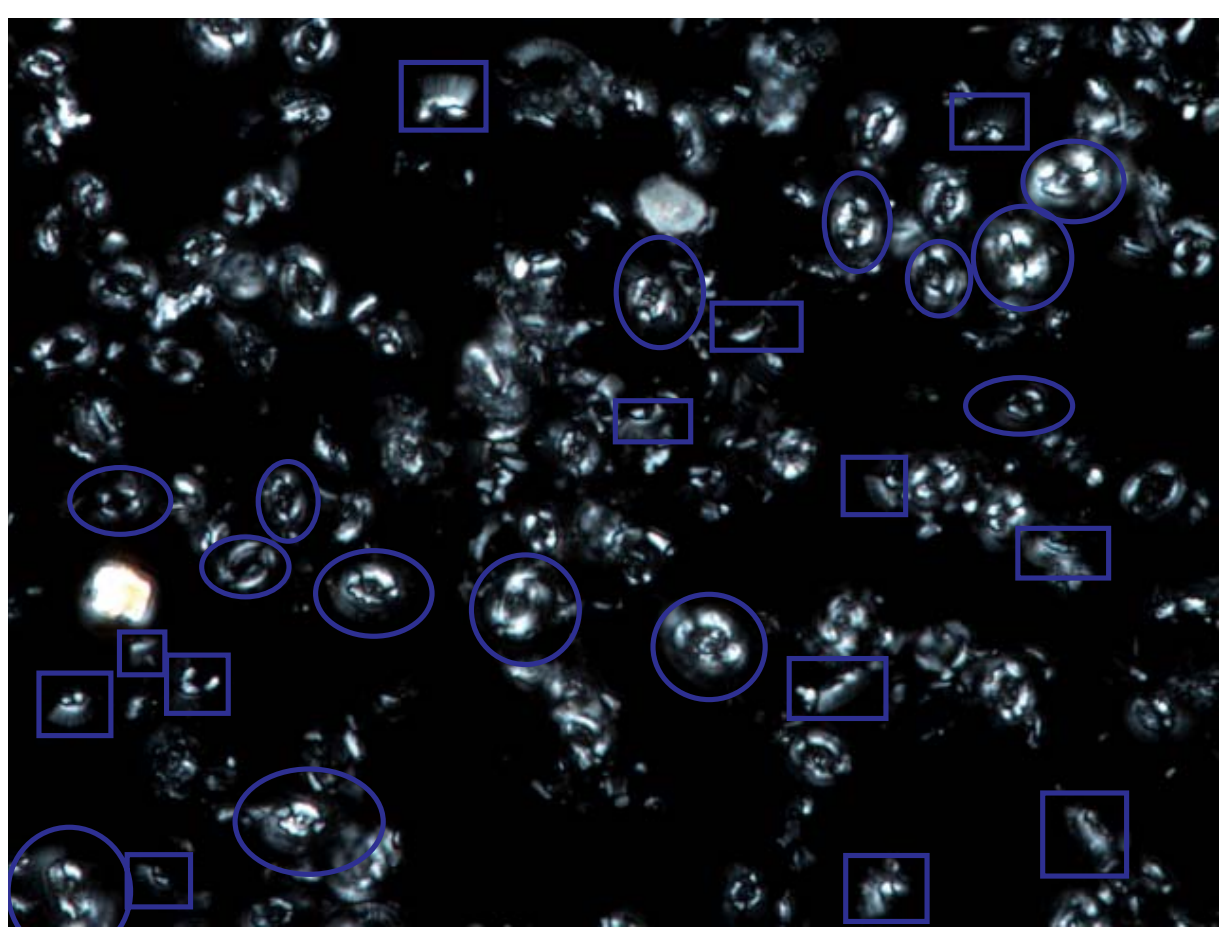

Fig. 6.2. Random field of view of ODP site 1090. To estimate the fragmentation of $C$. pelagicus we calculated the ratio between complete individuals (blue circle) and fragments (blue rectangle). 
The resulting fragmentation ratios (DL and DP) range betweeen 0 and 1, with 0 representing a sample with only complete individuals and 1 an assemblage were only fragments or distal shields have been observed.

\subsection{Comparison and evaluation of the different proxies}

From 3.1 to $2.82 \mathrm{Ma}$, NF increases from 1.5 to 4 . NF and SF reveal more and larger fragments between 2.72 and $2.3 \mathrm{Ma}$. During the latter interval, several samples with very high fragmentation have been observed and are highlighted in Fig. 6.3. Between 2.25 and $1.95 \mathrm{Ma} \mathrm{NF}$ is relatively stable and fluctuates around 4 and after this point decreases towards the top of the interval. DL and DP exhibit similar trends, suggesting a better preservation towards the top of the section. Nevertheless, some discrepancies can be found between 2.6 and $2.53 \mathrm{Ma}$ where high values of DL coincide with low values of DP. DP shows three distinct maxima between 2.3 and 2.7 Ma, highlighted in Fig. 6.4. DL has two distinct minima: around 2.93 and $2.34 \mathrm{Ma}$.

Comparison of the fluctuations of the different fragmentation indexes enabled us draw some general conclusions on the fragmentation/dissolution of the samples at ODP site 1090. Despite fluctuations, none of the indexes reveals prolonged periods of high fragmentation implying that dissolution did not control the nannofossil signal. Additionally, none of the indexes showed a relation with the G-IG cyclicity of the $\delta^{18} \mathrm{O}$ record, suggesting that glacial dissolution, as might be expected was not significant at ODP site 1090. All proxies indicate higher dissolution between 2.7 and 2.3 which might be related with important changes in the deep-water circulation or the water-chemistry of the ocean. The timing of the increased dissolution coincides with a general global cooling linked to the intensification of the Norhtern Hemipshere Glaciation. This general cooling might have caused an expansion of the corrosive Southern Component Water (AABW). High fragmentation before and after hiatus 3 and 4 is observed in all proxies and suggests that this hiatus might be caused by a strong dissolution event. The other hiatus do not show this pattern and may be due to other factors. Despite the similar trends observed in the different indexes, some significant discrepancies are observed leading to some uncertainties about our different dissolution proxies. Between 2.6 and 2.525 DP and DL show opposite trends. The differences between DP and DL might be related to the fact that dissolution might affect the different coccolithophores species in a different way. Not only dissolution but also mechanical destruction during (and after) the sediment process and the postdepositional dissolution may occur differently in C. leptoporus and C. pelagicus. Little is known about these factors and comparison of our record with another record situated at a different location might give additional information on the similarities and differences between DL and DP. Additionally, some significant discrepancies between NF on one hand and DP and/or DL on the other hand have been observed. NF and SF however are only an estimation of the degree of fragmentation and comparison between NF and DL or DP is not very reliable.

Fig. 6.3. Comparasion of the different dissolution proxies calculated for ODP site 1090. NF is represented by a gray solid area and the thick black line indicates the 5-point running average. Species-specific fragmentation ratios are represented in blue and red and the thick line again shows the 5-point running average. The hiatus are numbered from $1-5$ as in Venz and Hoddell (2002). The black arrows indicate samples with a high number of fragmentas. The section between 2.7 and $2.3 \mathrm{Ma}$ is amplified in the upper part of the figure. 

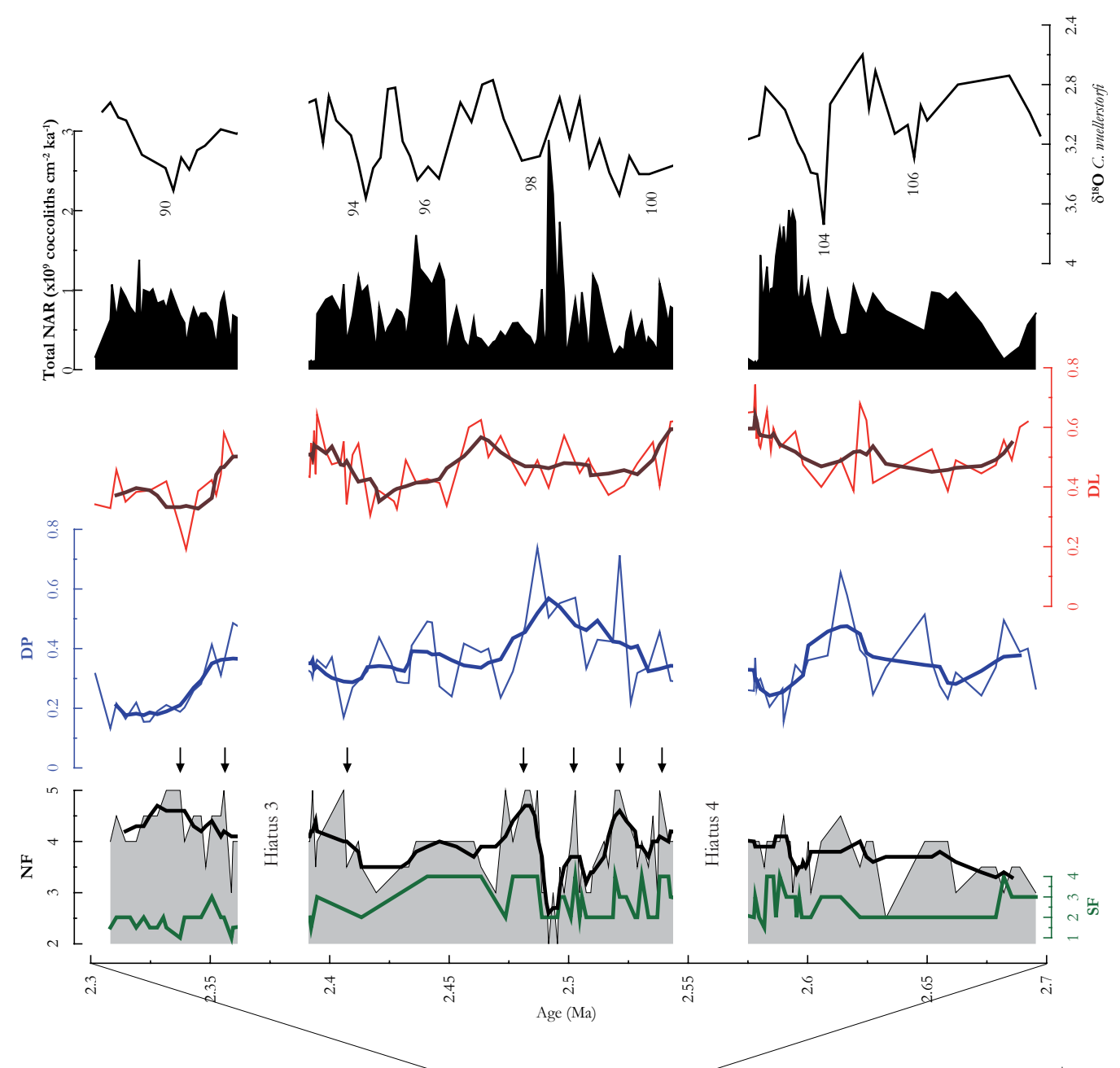

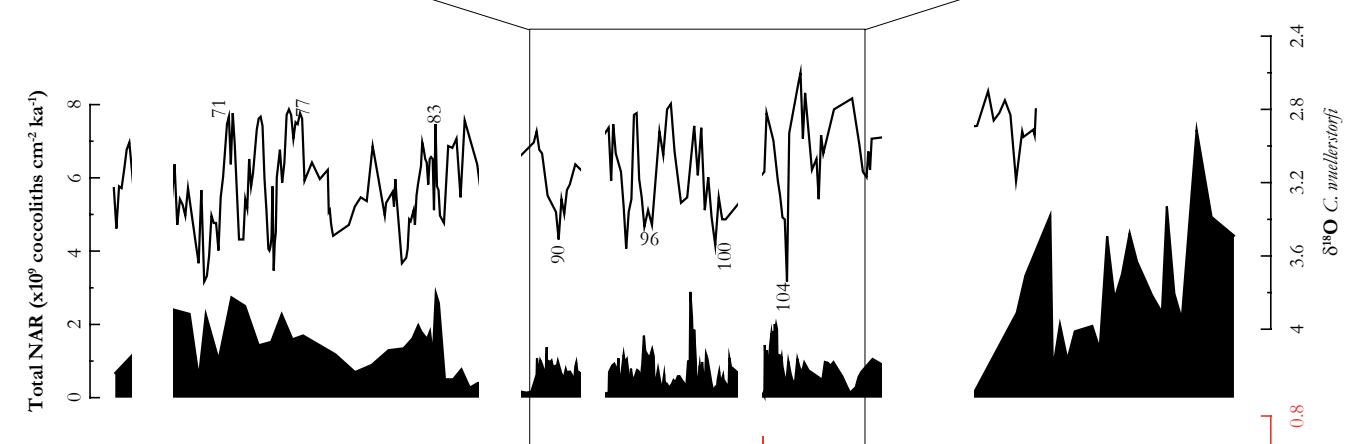

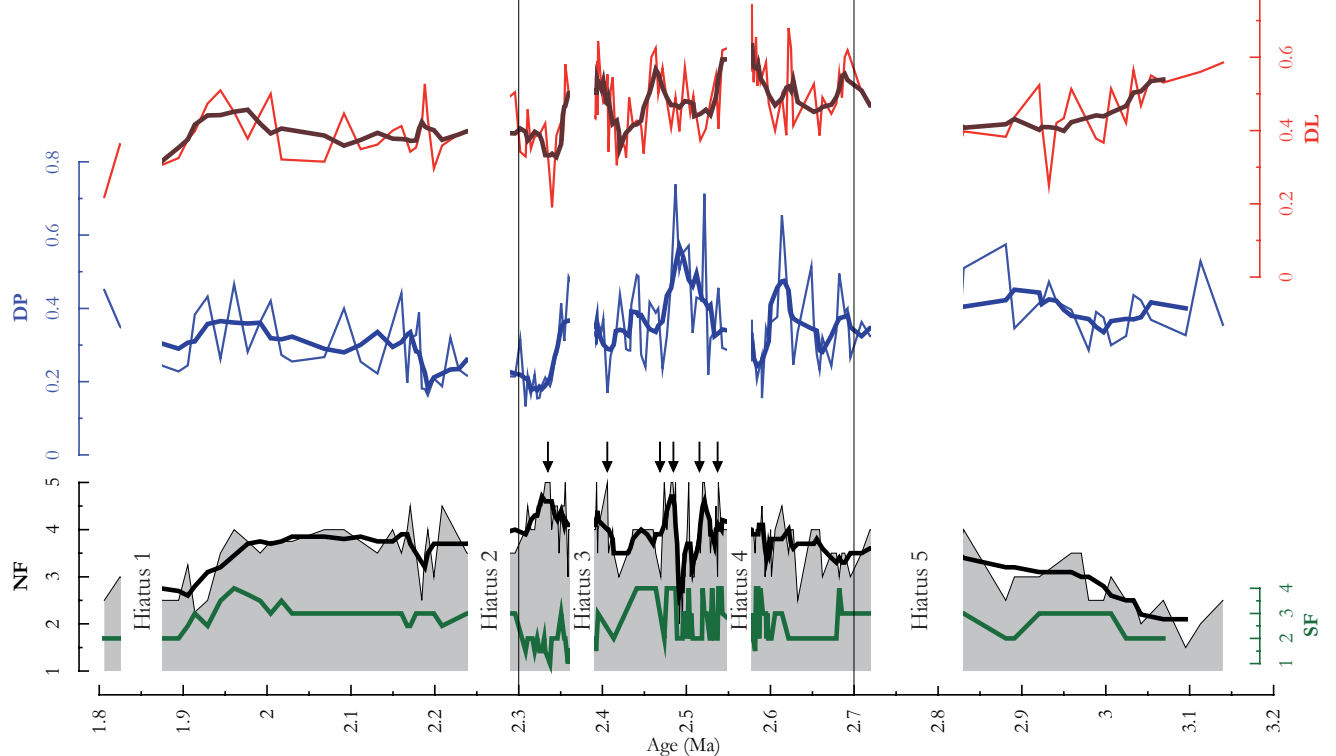




\subsection{Conclusions}

The calculation of four different fragmentation indexes ensured us that: (i) despite fluctuations, no prolonged periods of dissolution have been identified, allowing us to use the calcareous nannofossil record for paleoclimate studies and (ii) fragmentation was not related to G-IG variations ruling out glacial dissolution.

After estimating the degree of dissolution through different methods, we considered that the fragmentation ratios based on single species (DP and DL) are the most reliable proxies. The main disadvantage of the semicuanitative methods (NF and $\mathrm{SF}$ ) is the fact that they are subjective and lack of precise criteria that separate the samples into the different categories which makes it difficult to compare different sediment records. NF and SF do allow a ranking of general fragmentation within the same sediment record and this method can be used to make a rapid assessment of the general fragmentation of the calcareous nannofossil assemblage. On the contrary, a dissolution index based on a single taxon has already been proved to be good strategy since it is not influenced by the original faunal composition and allows comparison between different sediment records. The fragmentation ratios DP and DL, and their utilit fo reconstructing the deep water circulation, will be discussed more into detail in Chapter 7. 


\section{Chapter 7: COCCOLITHOPHORE \\ DISSOLUTION VERSUS PRODUCTIVITY \\ CHANGES DURING THE PLIO-PLEISTOCENE \\ (3.14-1.80 Ma) IN THE SOUTH ATLANTIC (ODP SITE 1090)}

Ballegeer, A.M., Flores, J.A., Sierro, F.J. and Gersonde, R.

To be submitted to Marine Micropaleontology

7.1. Introduction

7.2. Regional setting

7.3. Material and methods

7.3.1. Material

7.3.2. Sample preparation and counting technique

7.3.3. Preservation and dissolution proxies

7.3.4. Age model

7.3.5. Taxonomy

7.4. Results

7.5. Discussion

7.5.1. Paleoproductivity

7.5.2. Carbonate dissolution trends

7.5.3. The Eltanin impact

7.6. Conclusions 



\title{
CHAPTER 7: COCCOLITHOPHORE DISSOLUTION VERSUS PRODUCTIVITY CHANGES DURING THE PLIO- PLEISTOCENE (3.14-1.80 MA) IN THE SOUTH ATLANTIC (ODP SITE 1090).
}

\author{
Anne-Marie Ballegeer ${ }^{1, *}$, José A. Flores ${ }^{1}$, Francisco J. Sierro ${ }^{1}$ and Rainer Gersonde ${ }^{2}$ \\ 1 Área de Paleontología, Departamento de Geología, Universidad de Salamanca, 37008 Salamanca, \\ Spain. \\ ${ }^{2}$ Alfred Wegener Institute for Polar and Marine Research, P.B. 120161, D-27515 Bremerhaven, \\ Germany
}

\begin{abstract}
Calcareous nannofossil assemblages of ODP site 1090, situated in the South Atlantic, have been analyzed to reconstruct the paleoceanographic conditions between 3.14 and $1.8 \mathrm{Ma}$. Additionally, fragmentation ratios of two coccolithophore species (Coccolithus pelagicus and Calcidiscus leptoporus) have been calculated to (i) validate the number of nannofossils accumulated in the sediment as an indicator for the surface coccolithophore productivity and (ii) infer variations in the deepwater circulation of the Southern Ocean. During the analysis of the calcareous nannofossil signal, special attention has been given to the interval of the Eltanin impact, an asteroid that impacted in the Bellinghausen Sea around 2.5 Ma. The carbonate dissolution proxies suggest that dissolution did not control the nannofossil signal. The identified nannoplankton assemblages reveal four different intervals, each characterized by different oceanographic conditions. Interval I (3.14-2.82 Ma) has high coccolithophore productivity and low abundances of C. pelagicus and is interpreted as a relatively warm interval. High abundances of small placoliths during this period suggest that the site 1090 was situated close to the STF. Interval II $(2.72-2.20 \mathrm{Ma})$ is characterized by low coccolithophore productivity and a strong increasing abundance of $C$. pelagicus. This nannofloral shift indicates colder sea surface temperatures (SST) and a moderate northward movement of the oceanic fronts. The timing of this cooling coincides with the final closure of the Central American Seaway and it is suggested that both events are related. The general cooling is interrupted between 2.44 and $2.34 \mathrm{Ma}$, an interval with low abundance of $C$. pelagicus and high biodiversity, interpreted as a warm event. During interval II the nannofossil signal exhibits a glacial-interglacial pattern with increased productivity during Terminations. Interglacials are dominated by small placoliths whereas glacial are characterized by high percentages of C. pelagicus. During interval III (2.2-2.02 Ma) higher abundances of the warm species suggest a southward movement of the oceanic fronts around 2.1 Ma. During interval IV (2.02-1.8 Ma) conditions similar to interval I have been inferred. The coccolithophore fragmentation ratios indicate an increased preservation after $2.2 \mathrm{Ma}$ that has been related to a stronger Northern Component Water circulation in the South Atlantic. An anomalous high abundance of the small placoliths was observed around 2.49 Ma (MIS 99) and has been interpreted as a short period of higher nutrients concentration and/or more vigorous mixing of the superficial water column, possibly linked to the Eltnian impact.
\end{abstract}

Keywords: Calcareous nannofossils, Southern Ocean, Plio-Pleistocene, Paleoceanography, Eltanin 


\subsection{Introduction}

The Neogene is characterized by global cooling (Lisiecki and Raymo, 2005), and during the last 5 million years $(\mathrm{Ma})$, the Globe underwent a major reorganization of the climate system: (i) The closure of the Central American Seaway (CAS), starting around 4.6 Ma, cut off the connection between the Atlantic and Pacific Ocean causing a profound redistribution of the global oceanic circulation and the tropical heat (Haug and Tiedemann, 1998; Lear et al., 2003); (ii) Around 2.74 Ma the ice-build up of the Northern Hemisphere Glaciation (NHG) reached a point where it affected the global climate (Bartoli et al., 2005) ; (iii) An increased Walker circulation after $2 \mathrm{Ma}$ in the tropics and subtropics enhanced the west-east sea surface temperature (SST) gradient in the tropical Pacific and ends the permanent El Niño state that dominated the early Pliocene (Etourneau et al., 2010; Ravelo et al., 2004). Important climatic changes occurred at low and high latitudes and are believed to be linked to each other by important feedback mechanisms between distant locations (Ravelo et al., 2004). An increased latitudinal temperature gradient and shoaling of the thermocline at low latitudes starting around $2.75 \mathrm{Ma}$ have been proposed as important links between lowand high latitude climate changes during the Late Pliocene.

Another, less studied, event that could have affected the mid Pliocene climate is the Eltanin asteroid impact in the Bellinghausen Sea, dated around 2.5 Ma (Gersonde et al., 2005). The Eltanin impact was first discovered as an Ir anomaly in 1981 (Kyte et al., 1981) and is the only known asteroid impact in a deep-ocean basin. The impact may have caused megatsunamis, along the Pacific and the Southern Ocean shores, that affected the climate by ejections of large amounts of salt water into the atmosphere (Gersonde et al., 1997). A study of the sediment cores of the Bellinghausen Sea, made by Flores et al. (2002), did not reveal significant changes in the calcareous plankton association for the interval immediately after the impact, but relatively low sedimentation rates compared to the interval before the impact and the appearance of extensive bioturbation after the impact may be indicative of certain paleoenvironmental changes immediately after the impact. ODP Site 1096 (at $1300 \mathrm{~km}$ of the impact site) was examined to find traces of the impact, but in this case no strong evidence related to this impact was found (Kyte, 2001). The consequences of this impact on the climate have not been quantified and it has not been demonstrated to which extent this impact had effects on the Pliocene global climate (Flores et al., 2002; Gersonde et al., 1997; Gersonde et al., 2005).

Coccolithophores are unicellular autotrophic planktonic organisms that form a major component of the oceanic plankton, both at present as in the Pliocene. They form a carbonate cover around their cell that is preserved in the deep-sea sediments, and, therefore, are extensively used in biostratigraphic, paleoecologic and paleoceanographic studies (e.g. Baumann et al., 1999; Winter and Siesser, 1994). They are sensitive to environmental variations such as temperature, salinity, nutrient content and thus form an excellent tool to reconstruct paleoenvironmental conditions (McIntyre and Bé, 1967; Thierstein and Young, 2004; Winter and Siesser, 1994). In order to make accurate paleoecological or paleoclimatic interpretations, it is necessary to differentiate between floral changes that result from climatic or related environmental changes and those superimposed by dissolution. The alteration of calcareous microfaunal assemblages by calcium carbonate dissolution has been widely investigated (Berger, 1970; Dittert et al., 1999; Henrich et al., 2003; Thunell, 1976). Yet, most work is focused on foraminifers, mostly due to the fact that coccolithophores are really small and present complex sedimentation processes. Despite the hard effort, quantitative reconstruction of past carbonate dissolution remains difficult and most of the criteria used to judge the state of preservation of the calcite are qualitative (Flores et al., 2003; Peterson and Prell, 1985; Pujos, 1985). In addition, variations of 
the carbonate preservation in surface sediments of the South Atlantic and the Southern Ocean are believed to reflect the distribution of corrosive southern component water (SCW) respect to less corrosive northern component water (NCW) (Diekmann and Kuhn, 2002; Henrich et al., 2003). The relative proportion of these water masses gives an indication about the strength of the thermohaline circulation, which is an important feature that controls the global climate. Previous data, obtained from carbon isotopic gradients between benthic foraminifers from different locations, revealed important variations in the distribution of the deep water masses in the Southern Ocean during the last 2.9 Ma (Venz and Hodell, 2002). The most significant event a deepening of the NCW/SCW boundary after 1.8 Ma (Venz and Hodell, 2002).

Here, a nannofossil record of the late Pliocene, between 3.14 and $1.8 \mathrm{Ma}$ is studied to reconstruct the coccolithophore paleoproductivity, at supra-orbital and orbital scale. The main objective is to improve the insights in the mechanism behind, and the relation between, the climate changes of this period. Several dissolution indexes were calculated to exclude dissolution as the main factor controlling our nannofossil record, and, thus validate the number of nannofossils accumulated in the sediment as an indicator for the surface coccolithophore productivity. The calculated dissolution proxies will also be used to infer highresolution variations in the deepwater circulation of the Southern Ocean. Additionally, we are looking for significant changes/anomalies in the record that can be related to the Eltanin impact instead of being explained by orbital variations.

\subsection{Regional Setting}

ODP Site 1090 (42 54.8'S, 8 53.9’ E) is situated in the South-eastern Atlantic Ocean, on the southern flank of the Agulhas Rigde (Fig. 7.1). The South Atlantic ocean receives water from the North Atlantic, the Weddell Sea and the Antarctic Circumpolar Current (ACC). The Circumpolar and North Atlantic waters show widely different characteristics (temperature, salinity, oxygen and nutrient content) but have overlapping density ranges, and as they enter the South Atlantic are caught up in the ACC circulation imposed by winds and thermohaline processes (Reid, 1989).

The ACC is divided in three zones, separated by frontal systems, from north to south: the Subtropical front (STF), the Subantarctic Front (SAF) and the Polar Front (PF) (Fig. 7.1). The study location is situated between the STF and the SAF and is influenced by the ACC and distal eddies of the Agulhas Current Retroflection introduced from the Indian ocean around the Cape region of South Africa (Esper et al., 2004) (Fig. 7.1). Today, the STF has the strongest thermal and saline gradients, both at the surface and at depth (Stramma et al., 1990). Temperature drops from 17.9 to $10.6^{\circ} \mathrm{C}$ and salinity from 35.5 to $34.3 \%$. In the East Atlantic the STF is situated at about $41^{\circ} \mathrm{S}$. The SAF generally lies at $45^{\circ} \mathrm{S}$ and has a temperature drop from 9.0 to $5.1^{\circ} \mathrm{C}$.

ODP Site 1090, recovered at $3702 \mathrm{~m}$ water depth, is placed near the boundary of the NADW (NCW for the Pliocene epoch) and the underlying lower CDW (SCW for the Pliocene epoch), and above the carbonate compensation depth (CCD) (Shipboard Scientific Party, 1999). The position of the site, between STF and $\mathrm{SAF}$, makes it ideal for monitoring the movements of the frontal boundaries and their influences on the nannoplankton community. 


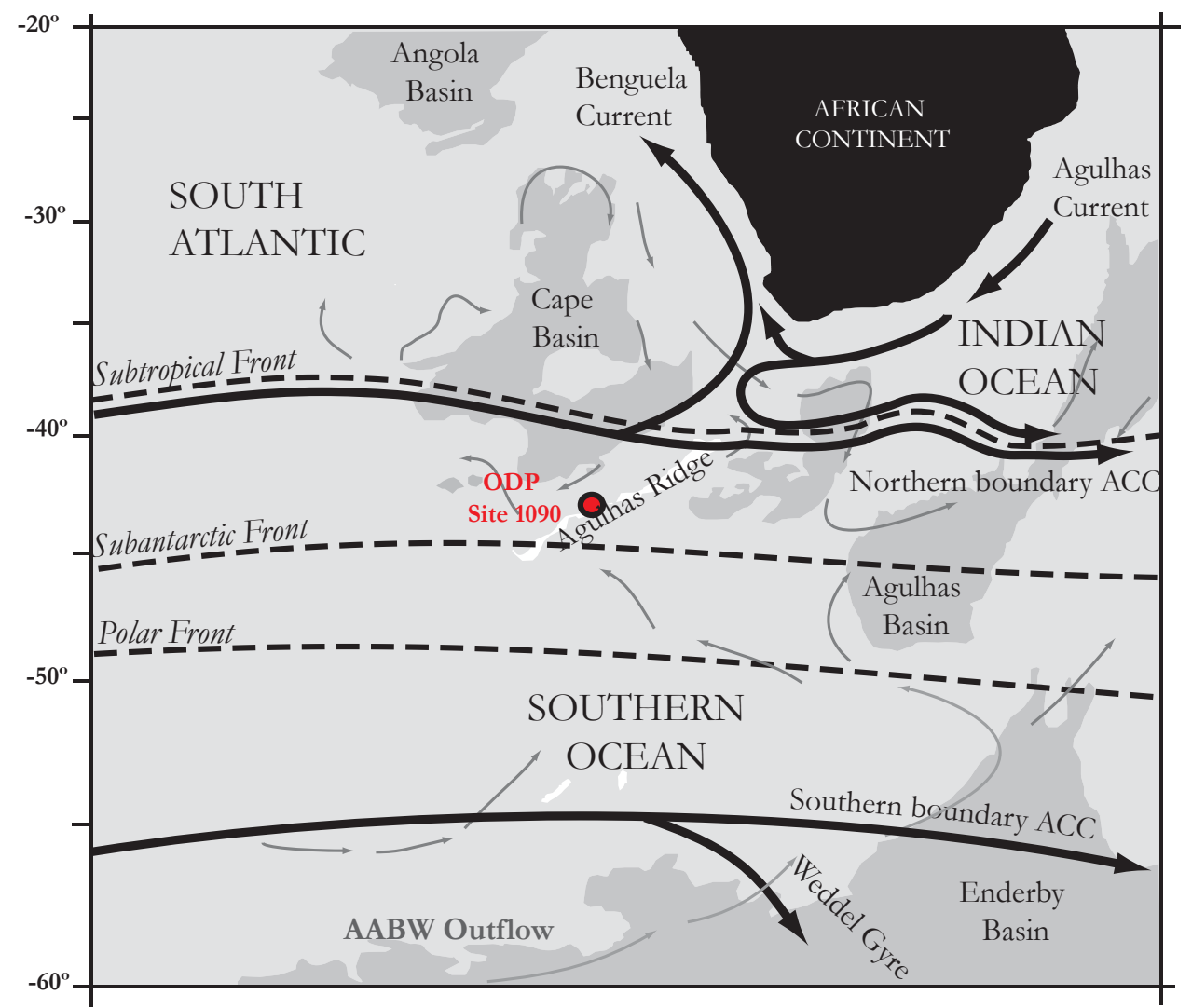

Fig. 7.1. Study area with position of site 1090. Black arrows depict the surface-ocean circulation, Gray arrows indicate the flow pattern of bottom contour currents which are independent of the surface circulation. The discontinuous lines show the actual position of the oceanic fronts. Oceanic topography is simplified to a schematic overview of the deeper basins and the contours of the Agulhas Ridge (modified from Kuhn and Diekmann, 2002).

\subsection{Material and Methods}

\subsubsection{Material}

A total of 232 samples from Hole 1090B and Hole 1090D, obtained during LEG 177 (Gersonde et al., 2003; Gersonde et al., 1999b) were studied. Sampling was carried out between 43.9 and 65.3 meters composite depth $(\mathrm{mcd})$ every $10 \mathrm{~cm}$. Between 51.0 and $56.21 \mathrm{mcd}$, a second sampling was done every $\mathrm{cm}$. The sediment shows alternations between pale gray foraminiferal nannofossil ooze and greenisch gray mud and diatom-bearing nannofossil ooze (Shipboard Scientific Party, 1999). Following the visual core descriptions, bioturbation is rare for Hole 1090B and moderate for Hole 1090D (Shipboard Scientific Party, 1999) and the average calcium carbonate content is $61 \%$ (Venz \& Hoddell, 2002).

\subsubsection{Sample preparation and counting techniques}

Nannofossil slides were prepared using the decantation method of Flores and Sierro (1997). For the preparation of each slide, 0.2 gram of sediment was used as an initial weight. The employed method allows calculation of the number of coccoliths per gram of sediment. Counting was done at 1000x magnification 
using a polarized light microscope. A total number of at least 400 specimens were considered. Bulk densities were taken from the ODP report (Gersonde et al., 2003), and linear sedimentation rates were calculated using the oxygen isotope stratigraphy of Venz \& Hodell (2002). After considerating the density and the linear sedimentation rate, this technique allows us to estimate nannofossil accumulation rates (NAR; coccoliths $\mathrm{cm}^{-2} \mathrm{ka}^{-1}$ ). The NAR values can be used as a proxy for the coccolitophore productivity (Flores et al., 2003). In addition to the total NAR, the counting procedure also allows us to calculate the relative abundance $(\%)$ and the NAR of the most abundant taxa.

\subsubsection{Preservation and dissolution indexes}

The criteria established by Flores et al. (2003) indicate that the effects of dissolution and overgrowth are moderate in all our samples, allowing the identification of all taxa. In order to have a more accurate knowledge about the effects of dissolution on our nannofossil assemblage, we calculated two dissolution indexes based on the fragmentation ratio of two individual species: Calcidiscus leptoporus (DL) and Coccolithus pelagicus (6-10 $\mu \mathrm{m})(\mathrm{DP})$. These indexes are based on the idea that increased fragmentation of fossil assemblages is directly related to dissolution (Berger, 1970). A dissolution index based on a single taxon is a good strategy for dealing with uncertainties in the knowledge of the original faunal composition of the assemblage (Peterson and Prell, 1985). For C. leptoporus we quantified the disarticulation of the proximal and the distal shield (DS), as proposed by Matsuoka (1990) and successfully used by other authors (Bolton et al., 2010; Findlay and Giraudeau, 2002). For C. pelagicus $(6-10 \mu \mathrm{m})$ we calculated the relation between complete individuals (CI) and fragments (F) which could be unambiguously identified as belonging to this species. We analyzed random visual fields of our homogeneously distributed samples and counted CI and F for C. pelagicus (6-10 $\mu \mathrm{m})$ and CI and DS for C. leptoporus until a number of $50 \mathrm{CI}$ was reached. Instead of determining the \% of complete individuals as Matsouka (1990), we used the following equation:

$$
D L=D S /(D S+C I)
$$

The resulting index, DL, ranges between 0 and 1, with 0 representing a sample with only complete individuals. $\mathrm{DP}$ is based on the same principle as the latter one and was defined using the next equation:

$$
D P=F /(F+C I)
$$

In order to estimate the diversity and dominance of the species of the nannofossil assemblage, the Shannonweaver diversity was calculated with the PAST (PAleontology STatistic) software (Hammer et al., 2001). To correct for the effect of dilution in the sediment, the $\mathrm{CaCO}_{3}$ content (\% wt) of Venz \& Hodell (2002) was converted to Mass Accumulation Rate (MAR) using the following formula:

MAR $\mathrm{CaCO}_{3}\left(\mathrm{~g} \mathrm{~cm}^{-2} \mathrm{ka}^{-1}\right)=\% \mathrm{CaCO}_{3}$ x GRA bulk density $\left(\mathrm{g} \mathrm{cm}^{-3}\right) \times \mathrm{S}\left(\mathrm{cm} \mathrm{ka}^{-1}\right) \times 100$

\subsubsection{Age Model}

From a biostratigraphic point of view, our record comprises zones NN16, NN17 and NN18 (Martini, 1970). This situates it after the last occurrence (LO) of Reticulofenestra psendoumbilicus (at $3.80 \mathrm{Ma}$ ) and Sphenolithus spp. (at 3.65 Ma) (Raffi et al., 2006). Individuals of these species are rare and their sporadical occurrence can be explained as a result of reworking. Pseudoemiliana lacunosa, which has its first occurrence (FO) at 4.0 Ma (Raffi et al., 2006) is found, though in very low percentages. Discoasterids are scarce, reason why it is not possible to identify some standard events. Calcidiscus macintyrei is present in the whole interval which 
confirms that the sampled interval does not reach Pleistocene sediments (Raffi et al., 2006).

Age assignments are based on the oxygen isotope stratigraphy of Venz and Hodell (2002). These authors performed isotopic analysis on planktonic (Globigerina bulloides) and benthic (Cibicidoides wuellerstorfi) foraminifers. Age/Depth points for ODP site 1090 were assigned based on the correlation of the oxygen isotopic record to ODP site 607. Despite some short hiatus identified by Venz \& Hodell (2002), the isotope record presents enough resolution to perform our paleoceanographic study (Fig. 7.2). Sample ages were obtained by linear interpolation on composite depths. The last age/depth point was situated at $57.33 \mathrm{mcd}$ and dated at $2.90 \mathrm{Ma}$. This means that for age calculations of the interval older than the last age/depth point, the sedimentation rate was assumed to be constant (Fig. 7.2). For site 1090 we observed an increasing trend between 3.0 and $1.8 \mathrm{Ma}$ towards heavier isotopic values. The highest $\delta^{18} \mathrm{O}$ fluctuations are registered around 2.6 Ma and between 2.0 and 1.9 Ma.

\subsubsection{Taxonomy}

A total of 15 species were identified. The recently adopted subdivision of $C$. pelagicus into different subspecies/morphotypes (Narciso et al., 2006; Parente et al., 2004) was not used since previous analysis of a number of samples under the SEM showed that $>90 \%$ of all individuals belonged to the subspecies: C. pelagicus ssp. pelagicus (6-10 $\mu \mathrm{m}$ ), the arctic form (Parente et al., 2004). Here we chose to use the term $C$. pelagicus $(6-10 \mu \mathrm{m})$ for our further analysis. In addition to the identified species, 3 morphological groups for the genus Reticulofenestra and 2 morphological groups for the genus Gephyrocapsa (see appendix) were considered. Finally, some extra groups were made to aid paleoceanographic interpretation of the nannofossil signal. The first group was labeled "small placoliths". The main reason for this is the small size and similar morphology of the genus Reticulofenestra and Gephyrocapsa smaller than $3 \mu \mathrm{m}$, which makes separation under the LM difficult. Besides, their identification is further complicated by dissolution that may dissolve the bridges of small Gephyrocapsa, leading to misidentification of these species. The term small placoliths has been employed by other authors and has been used as an indicator for nutrient-rich waters and/or upwelling areas. Secondly, we lumped together all the other species and this due to the low percentages of all other species apart from the small placoliths and C. pelagicus. The species included in this group are: Calcidiscus leptoporus, Calcidiscus macintyrei, Reticulofenestra spp., Syracosphaera sp., Raabdosphaera sp., Florisfera profunda, Helicosphaera spp., Pontosphaera spp. and Discoaster spp (see appendix).

\subsection{Results}

Different NAR values allow us to identify four different intervals distinguishable by a different species composition and nannofossil accumulation rate.

\section{Interval I (between 3.14 and $2.82 \mathrm{Ma}$ )}

Characterized by high total NAR values (average: $2.9 \times 10^{9}$ coccoliths $\mathrm{cm}^{-2} \mathrm{ka}^{-1}$ ) and the assemblage is strongly dominated by small placoliths (Fig. 7.3). The average contribution of C. pelagicus (6-10 $\mu \mathrm{m})$ and the other species is rather low, under $20 \%$. The NAR patterns of the different taxa reveal the same distribution as the relative abundances. The diversity is stable, showing low-amplitude fluctuations (Fig. 7.2). Dissolution 
indexes DL and DP do not show any significant trend. The average value of this interval is 0.4 for DL and 0.43 for DP (Fig. 7.2).

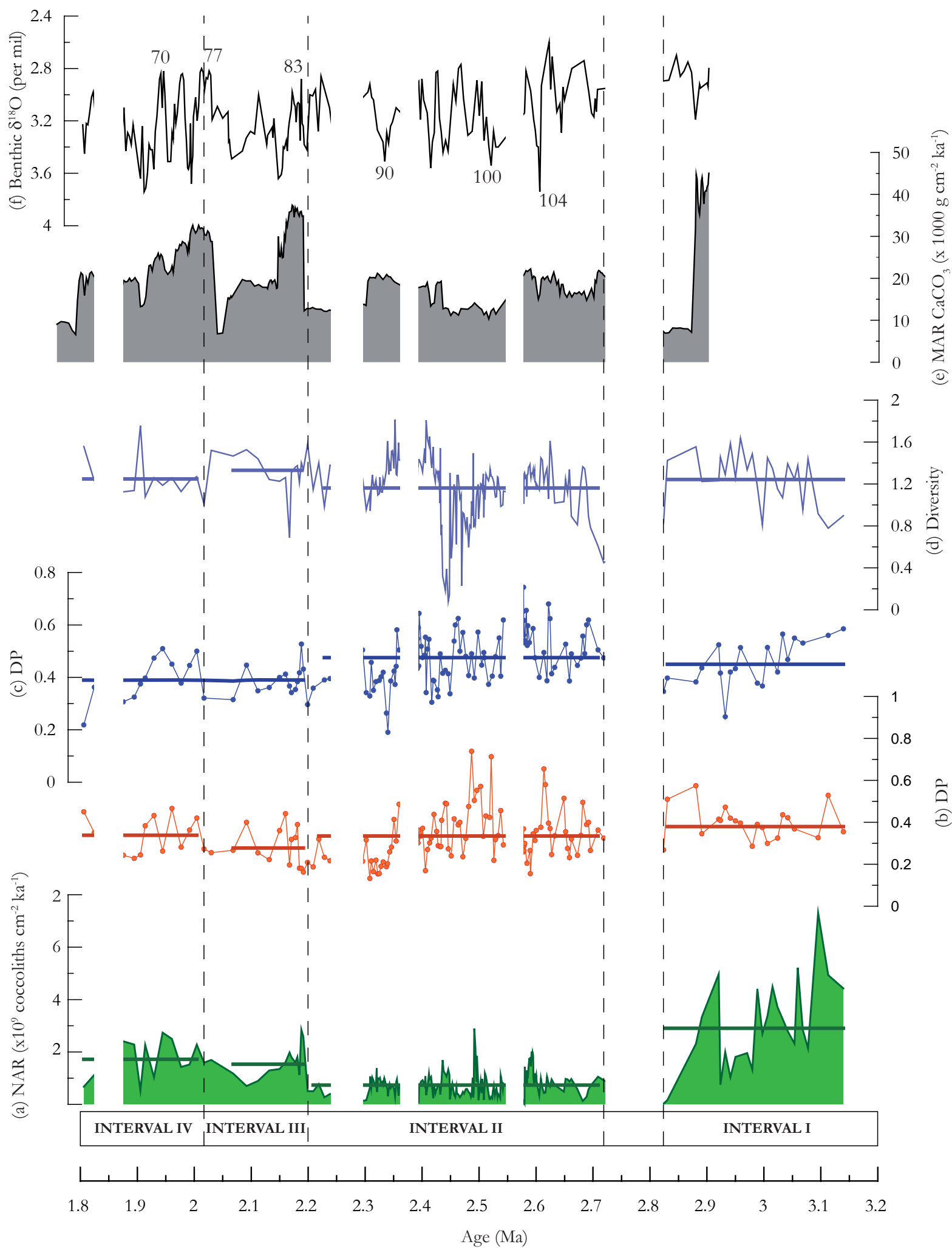

Fig. 7.2. Carbonate dissolution in the sediment record between 3.2 and $1.8 \mathrm{Ma}$ at ODP site 1090. Graphics show the distribution patterns of: (a) total NAR (coccoliths $\mathrm{cm}^{-2} \mathrm{kyr}^{-1}$ ), (b) fragmentation index C. pelagicus (DP), (c) fragmentation index C. leptoporus (DL), (d) Shannon weaver diversity, (e) the $\mathrm{CaCO}_{3}$ Mass Accumulation Rate (MAR) and (f) the benthic $\delta^{18} \mathrm{O}$ record of Venz \& Hoddell (2002). 

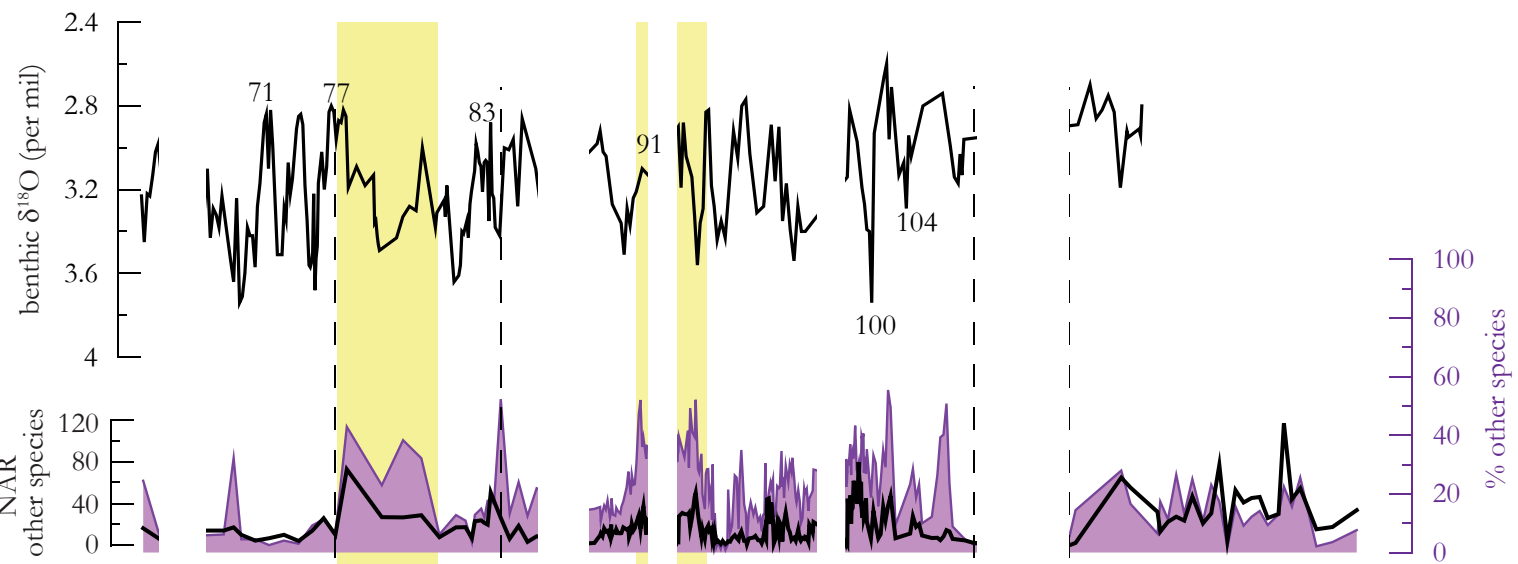

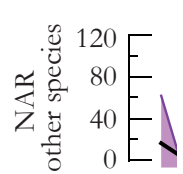
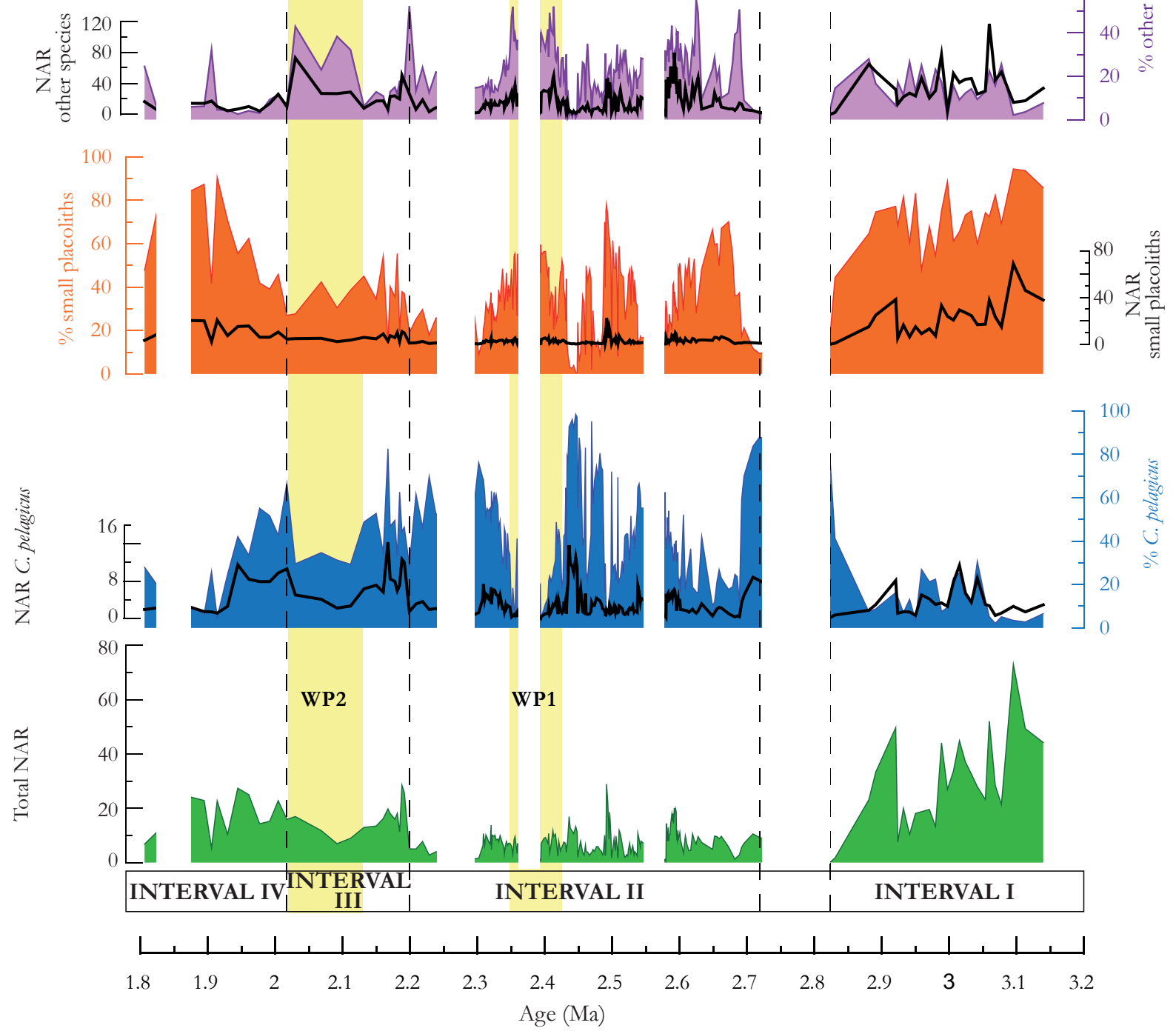

Fig. 7.3. Long term variations in the nannofossil assemblage. The total nannofossil accumulation rate is compared with the relative (solid area) and absolute abundances (black line) of the main taxa. The nannofossil signal is compared with the benthic $\delta^{18} \mathrm{O}$ record (Venz and Hodell, 2002).

\section{Interval II (between 2.72 and $2.20 \mathrm{Ma}$ )}

Interval II is characterized by low total NAR values (average: $7.4 \times 10^{8}$ coccoliths $\mathrm{cm}^{-2} \mathrm{ka}^{-1}$ ), except three periods of remarkably higher total NAR: from 2.60 to $2.58 \mathrm{Ma}$; between 2.50 and $2.49 \mathrm{Ma}$ and for 2.45-2.43 $\mathrm{Ma}$ (Fig. 7.3 \& 7.4). This Interval has a higher sample resolution that allowed us to observe the nannofossil record at a suborbital scale (Fig. 74). The total NAR values show glacial-interglacial (G-IG) variations and maxima are registered during Terminations, except for the maximum observed between 2.50 and 2.49 Ma, coinciding with MIS 99 (Fig. 7.4). The NAR values increase during the glacial stages, except during 
MIS 100 (Fig. 7.4). Alternating abundances of small placoliths and C. pelagicus $(6-10 \mu \mathrm{m})$ were correlated with the G-IG cycles: generally, interglacial stages are characterized by high relative abundances of small placoliths and glacial stages are dominated by $C$. pelagicus $(6-10 \mu \mathrm{m})$. However, some exceptions are seen: the interglacial MIS 103 has very low small placoliths abundance and glacial stage MIS 100 has rather high small placoliths abundances (Fig. 7.4). Superimposed on the G-IG variation, C. pelagicus (6-10 $\mu \mathrm{m})$ shows an increasing relative abundance between 2.7 and $2.4 \mathrm{Ma}$ (Fig. 7.3) and higher abundance of the other species are registered for 2.44-2.34 Ma. The NAR of the separate taxa does not reveal the same fluctuations as the relative abundances, the values are stable along the G-IG cycles, except for MIS 96 and 99. C. pelagicus (6$10 \mu \mathrm{m})$ has very high NAR values during MIS $96\left(1.5 \times 10^{9}\right.$ coccoliths $\left.\mathrm{cm}^{-2} \mathrm{ka}^{-1}\right)$ whereas during MIS 99 the small placoliths reach very high NAR values $\left(2.2 \times 10^{9}\right.$ coccoliths $\left.\mathrm{cm}^{-2} \mathrm{ka}^{-1}\right)$ (Fig. 7.4). The diversity ranges around the same values as during interval I, but reaches a distinct minimum during MIS 96, around $2.44 \mathrm{Ma}$ (Fig. 7.2). The fragmentation ratios show short-term fluctuations and the average values of DL and DP are nearly the same for intervals II and I. Although, punctual high values are reached for both DL as DP

\section{Interval III (between 2.2 and $2.02 \mathrm{Ma}$ )}

This is a rather short interval compared to the previous ones. The total NAR average values are higher: 1.5 $\mathrm{x} 10^{9}$ coccoliths $\mathrm{cm}^{-2} \mathrm{ka}^{-1}$ (Fig. 7.2). Remarkable for this period is that the three taxa have similar abundances (Fig. 7.3). Higher abundance of other species is registered between 2.12-2.02 Ma. The recorded NAR values and the relative abundances show the same pattern. The diversity is slightly higher (1.33) than during II (1.16), and, despite a minimum at 2.16 Ma, stable. The average DL and DP for this interval are 0.39 and 0.27 respectively. The fluctuations of the fragmentation ratios do not show any significant maxima (Fig. 7.2).

\section{Interval IV (between 2.02 and $1.80 \mathrm{Ma}$ )}

The NAR values show an average abundance of $1.7 \times 10^{9}$ coccoliths $\mathrm{cm}^{-2} \mathrm{ka}^{-1}$, this is higher than during II and III, but lower than I (Fig. 7.2). After $2.0 \mathrm{Ma}$, the small placoliths dominate the assemblage and the species distribution is very comparable to I. The relative abundance of C. pelagicus (6-10 $\mu \mathrm{m})$ reaches minimum values towards the end of the record and the contribution of the other species is very low. The NAR fluctuations of the taxa show the same pattern as the relative abundances. Biodiversity is stable and ranges around 1.24. The fragmentation ratios show low fluctuations and around 1.88 Ma both DL and DP are lower than in the rest of the interval. Between 2.02 and $1.80 \mathrm{Ma}$, DL has an average of 0.39 and DP 0.34 (Fig. 7.2).

\subsection{Discussion}

\subsubsection{Paleoproductivity}

\section{Interval I (3.14-2.82 Ma)}

The period before $2.82 \mathrm{Ma}$ is characterized by high total NAR values. The fragmentation ratios are constant, indicating that the NAR signal can be used as a proxy for coccolithophore productivity. The low abundances of C. pelagicus (6-10 $\mu \mathrm{m})$, traditionally described as a cold water indicator (Geitzenauer, 1972; Geitzenauer et al., 1976; McIntyre and Bé, 1967; Okada and McIntyre, 1977; Okada and McIntyre, 1979; Raffi and Rio, 1981), suggest higher SST's for interval I. The high abundances of the small placoliths, described as 
an upwelling indicator (Gartner, 1988; Okada and Wells, 1997; Takahashi and Okada, 2000b), indicate a permanent disturbance of the water stratification that might be related to a closer proximity of site 1090 to the STF. The STF is described as a zonal band of active mixing and enhanced productivity (Bard and Rickaby, 2009) that might have favored the development of these species adapted to unstable and highnutrients conditions such as the small placoliths (Gartner, 1988; Gartner et al., 1987; Okada and Wells, 1997; Takahashi and Okada, 2000). Our results suggest that site 1090 was situated in the SAZ, but closer to the STF than at present day. These ideas corroborate the hypothesis stated by Haywood \&Valdes (2004) and Raymo et al. (1996), defending the idea that before 3 Ma the world had a warmer climate and that the Antarctic ice volume was strongly reduced.

\section{Interval II (2.72-2.20 Ma)}

Interval II starts with a shift from high- to low total NAR values that occurred between 2.8 and $2.72 \mathrm{Ma}$. This is interpreted as reduced coccolithophore productivity and corresponds with an important change in the nannoflora, from abundant small placoliths to abundant C. pelagicus $(6-10 \mu \mathrm{m})$ (Fig. 7.2). The increased abundance of $C$. pelagicus $(6-10 \mu \mathrm{m})$ and heavier benthic $\delta^{18} \mathrm{O}$ values (Venz and Hodell, 2002) indicate that decreased NAR most likely is related to low SST's. We suggest that the gradual closing of the CAS, starting around 2.8 Ma, occurs together with a northward movement of the SST gradients in the Southern Ocean. Despite the fact that cooling suggest a northward displacement of the fronts, our data do not show evidences that the SAF moved over the study site. The nannofossil signal indicates that cooling in the Subantarctic ocean reduced the coccolithophore production. Other evidences that confirm a significant cooling in the Atlantic Ocean after the closure of the CAS are found from different proxy-records: $\mathrm{Mg} /$ Ca-paleothermometry with benthic foraminifera (Lear, 2003), biogenic opal accumulation calculated with diatoms (Cortese and Gersonde, 2008) and a pollen record of South Africa (ODP site 1082) (Dupont, 2006; Dupont et al., 2005). Following our interpretation, a decreasing temperature in the South Atlantic is coupled with a northward movement of the SST gradients or oceanic fronts of the Southern Ocean. Indeed, a northward shift of the STF at 3.0-2.8 Ma has also been observed during previous studies, both in the South Atlantic (Diekmann et al., 2003) and in the South Pacific (Gallagher et al., 2003). In addition to our study in the South Atlanic, a profound climate change around 2.8 Ma is also visible in other oceans. Most remarkable is the shift from abundant placoliths to a barren interval or abundant C. pelagicus identified in the Arctic Ocean and the Japan Sea (dated at $2.74 \mathrm{Ma}$ ) and that has been linked to the closure of the CAS (Sato et al., 2002; Sato et al., 2004). This same shift is observed at ODP site 1090.

Despite the deduced general cooling of the South Atlantic, an important drop in the abundance of C.pelagicus (6-10 $\mu \mathrm{m})$ is observed between 2.44 and $2.34 \mathrm{Ma}$, coinciding with a sudden increase of the Shannon-Weaver diversity index and higher abundances of the other species (Fig. $7.3 \&$ 7.4). These findings are interpreted as a warm pulse (WP1; Fig. 7.3) disrupting the general cooling registered since 2.8 Ma. WP1 is interpreted as an interval characterized by more subtropical-like conditions linked to a temporal southward displacement of the SST gradients, but without crossing ODP site 1090. A remarkable increase in abundance of the diatom Actinocyclus ingens, believed to indicate warmer Subantarctic conditions (Fenner, 1991; Gersonde and Bárcena, 1998), at ODP site 1090 around 2.4 Ma corroborates the interpretation of WP1 (Cortese and Gersonde, 2008).

At G-IG scale, variations of the nannofossil record reveal higher nannofossil productivity during Terminations. A Higher input of nutrients caused by enhanced wind activity during glacial periods, as 


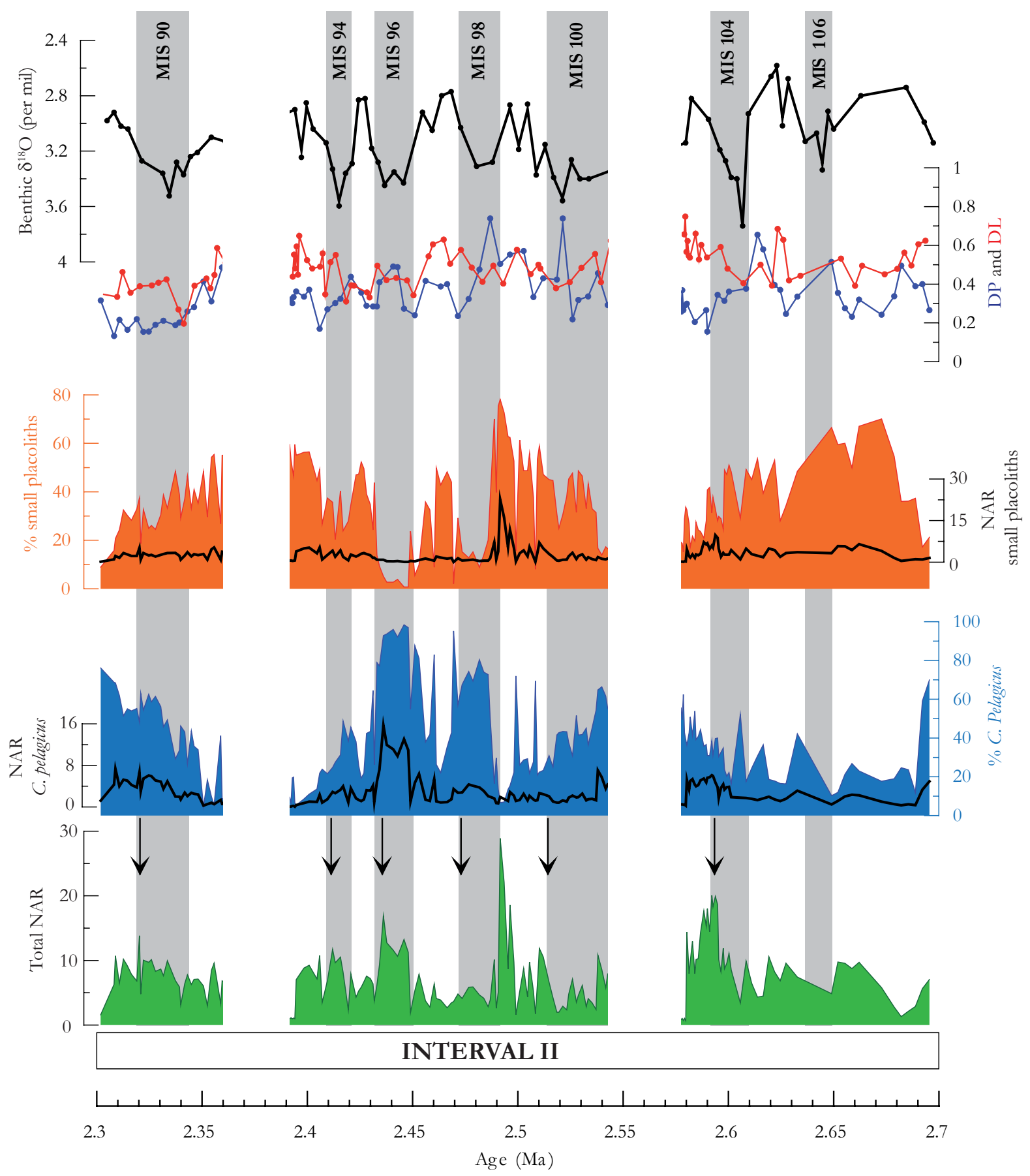

Fig. 7.4. Glacial-interglacial variability of the coccolithophore assemblage between 2.7 and $2.3 \mathrm{Ma}$. Arrows indicate increased productivity during glacial terminations. The nannofossil signal is compared with the fragmentation ratios $\mathrm{DP}$ and DL and the benthic $\delta^{18} \mathrm{O}$ record.

suggested by Latimer \& Filippelli (2001), explains the increasing NAR values during almost all glacial stages (except MIS 98) that culminates in higher productivity during terminations. The low NAR values of MIS 98 can be explained by higher dissolution as indicated by DP and DL (Fig. 7.4). C. pelagicus (6-10 $\mu \mathrm{m}$ ) and small placoliths are the main contributors of the assemblage and their relative abundance shows a G-IG pattern. Glacial stages are characterized by an increased percentage of $C$. pelagicus (6-10 $\mu \mathrm{m})$ while higher abundances of the small placoliths are recorded during IG. The high abundance of C. pelagicus $(6-10 \mu \mathrm{m})$ is related to cold SST during G, in agreement with previous ecological descriptions (Beaufort and Aubry, 1990; Bukry, 1991; Narciso et al., 2006; Raffi and Rio, 1981). We believe that, independently of the long term 
variations of the position of the oceanic fronts, a southward movement of the oceanic fronts took place during IG's. The higher proximity of 1090 to the STF would result in more intense mixing of the upper water column, allowing small placoliths to reach higher abundances. The described glacial productivity pattern and the expected high relative abundances of C. pelagicus $(6-10 \mu \mathrm{m})$ are not seen during MIS 100. Unusual high abundances of small placoliths during MIS 100 suggest that intense mixing persisted during this glacial period.

\section{Interval III (2.2-2.02 Ma)}

During interval III, coccolithophore productivity was higher than in the preceding interval and the relative abundances of the different taxonomic groups have similar proportions. The relative abundance of $C$. pelagicus $(6-10 \mu \mathrm{m})$ does not show any significant changes, outruling an important temperature shift during this interval. Coccolithophores are known to display latitudinal zonation (McIntyre and Bé, 1967; Ziveri et al., 2004) and diversity strongly increases towards lower latitudes (Winter and Siesser, 1994). Hence, higher abundances of the other species and higher diversity probably are linked to a greater influence of the STF. This interval is interpreted as a period of warmer SST (WP2; Fig. 7.3), coupled with a more poleward position of the STF, allowing abundant coccolithophore productivity. Again, despite the inferred movement of the STF, we interpret that ODP site 1090 remained in the SAZ.

In the South Atlantic, other proxies corroborate our interpretation of increased SST's linked to a poleward displacement of the oceanic fronts: (i) Pollen concentration and accumulation rates of ODP site 1082 (South Atlantic) show a strong sign of aridification and increased climatic variability after 2.2 Ma that has been related to a southward shift of the oceanic fronts, reducing the influence of the Atlantic Ocean into the continent and decreasing the extension of the winter rain vegetation (Dupont, 2006) and (ii) The isotope record suggests that the Southern Ocean became relatively warmer after 2.2 Ma (Hodell and Venz, 1992).

At a global scale, reconstruction of the Plio-Pleistocene evolution of the meridional SST gradient in the western Pacific (Jia et al., 2008; Wang, 1994) and in eastern boundary current systems (Etourneau et al., 2009; Liu et al., 2008) point towards stronger trade winds and the beginning of the Hadley circulation, as a consequence of increased pole to equator gradient, around $\sim 2.2-2.0 \mathrm{Ma}$ ago. This enhanced atmospheric circulation may have affected the superficial ocean circulation, favoring a more active mixing of the upper water column. This hypothesis is compatible with the increased coccolithophore production we have observed during this interval.

\section{Interval IV (2.02-1.8 Ma)}

Around 2 Ma small placoliths recover their high relative abundances and the other species exhibit a sudden decline. These floral changes go together with another increase of the total NAR. We propose that these changes result from persistent mixing of the upper water column and consequent higher nutrient content in the surface waters. These changes are accompanied with higher SST as inferred from the reduced relative abundance of $C$. pelagicus. The coccolithophore assemblage is very similar to interval I, suggesting that the STF was situated at the same position as before $2.82 \mathrm{Ma}$. This is in contrast with a study of six cores along a north-south transect of the ACC performed by Cortese and Gersonde (2008). They proposed a northward movement of the oceanic fronts related to a major increase in biogenic silica mass accumulation rate, synchronous to the FO of the diatom F. kerguelensis around 1.93 Ma (Cortese and Gersonde, 2008). 


\subsubsection{Carbonate dissolution trends}

Carbonate dissolution is not only important to validate the nannofossil signal observed in the sediments as a reflection of the surface productivity but also holds important information about variations of the deepwater chemistry and circulation. The dissolution proxies that were calculated in this study show that the average carbonate preservation does not exhibit strong variation between 3.2 and $1.8 \mathrm{Ma}$. Nevertheless, a decreased fragmentation and smaller variations of the fragmentation ratio after $2.2 \mathrm{Ma}$ have been observed in both proxies, interpreted as a better carbonate preservation for this period.

Site 1090 is situated in the proximity of the boundary between NCW and SCW, the NCW being less corrosive compared to the SCW. Based on this idea, we infer a greater NCW input in the Cape basin after 2.2 Ma. This is in agreement with Mix et al. (1995) who estimated that the period between 2.1 and $1.3 \mathrm{Ma}$ was characterized by the greatest NCW production of the past $3.0 \mathrm{Ma}$. Moreover, the $\delta^{13} \mathrm{C}$ record from Sikes et al. (1991) indicates low NCW circulation between 2.5-2.15 Ma which is also in agreement with the indications of our dissolution proxies.

Independent of this long term trends, carbonate dissolution also is known to show important variations related with the G-IG cyclicity (Bickert and Wefer, 1996; Howard and Prell, 1994; Le and Shackleton, 1992). For the late Pleistocene section of ODP site 1090, Hodell et al. (2001) found an 'Atlantic type' carbonate pattern with greater fragmentation during glacial periods and less fragmentation during interglacials. Despite the lack of a consistent relation between our dissolution record and G-IG cyclicity, the three dissolution events that were identified coincide with glacial periods (MIS 104-105, 100 and 98). Glacials became more severe after $2.7 \mathrm{Ma}$ and we suggest that higher coccolithophore dissolution during certain glacial stages may be related to an expansion of the more corrosive south component water (SCW). Both Venz \& Hodell (2002) as Sikes et al. (1991) didn't infer G-IG variation of the deepwater circulation during the Late Pliocene. Nevertheless, the fact that these authors did not consider G-IG variation before $1.8 \mathrm{Ma}$ does not exclude the possibility of moderate G-IG variation in certain occasions, as can be interpreted from our dissolution proxies.

We can not rule out the possibility that the variation observed in DP results from other factors influencing the carbonate preservation, such as mechanical destruction during the sedimentation process, as has been suggested by Matsouka (1990) or higher organic content in the sediments, etc.

\subsubsection{The Eltanin impact}

During interval II the species composition of the coccolithophore assemblage generally follows G-IG cycles. This dynamics shows an anomaly during MIS 99: the accumulation rate of the small placoliths reaches peak-values superior at $1.2 \times 10^{10}$ coccoliths $\mathrm{cm}^{-2} \mathrm{kyr}^{-1}$, while during all other interglacial periods values do not exceed $6.0 \times 10^{9}$ coccoliths $\mathrm{cm}^{2} \mathrm{kyr}^{-1}$ (Fig. 7.4). In other interglacial periods the small placoliths dominate the assemblages, having values higher than 75\%, nevertheless, the NAR only reaches extreme values at the end of MIS 99. The increase of the small placoliths ended abruptly at the beginning of MIS 98 and the duration of the high accumulation is $9 \mathrm{ka}$. The benthic isotopes do not indicate abnormal values for MIS 99 (Fig.7.4). Large quantities of small placoliths indicate a period of higher nutrients concentrations in the surface waters, increased mixing of the water column or a period of high environmental stress. High-resolution integrated magneto-biostratigraphic analysis constrains the age of the Eltanin impact to 2.5 
$\mathrm{Ma}$ (Gersonde et al., 2005), very close to the high VSR values.

The sudden deposition of large quantities of water, salt and dust in the atmosphere as well as chemical reactions resulting from the shock wave generated by the impact, cause environmental and climatic shortand long term effects (Gersonde et al., 1997; Toon et al., 1997). Tsunami modeling reveals that only few hours after the impact tsunamis with a height of more than 50 meters must have reached the Antarctic and South American coast lines, having potential to destabilize Antarctic ice shelf areas in the Pacific sector (Ward and Asphaug, 2002). Tsunami deposits found in Chile (Felton and Crook, 2003; Le Roux et al., 2008) have been tentatively related with the Eltanin. The high productivity interval of the small placoliths thus could be a reflection of the consequences of the impact. The particles (soil, dust and sulfate aerosols) introduced in the atmosphere after the impact could have caused acid rain and a consequent biotic crisis, favoring opportunistic species with a high capacity for adaptation such as the small placoliths. The major flaw in this hypothesis is that there are no evidences that particles can stay in the atmosphere during such a prolonged time (several ka). Simulations of the environmental effects of impacts consider the consequences of an impact for the consequent years, not ka (Toon et al., 1997). Given the lack of knowledge of climatic effects caused by asteroid impacts, it is difficult to propose an alternative hypothesis including long term effects caused by the impact. Our nannofossil record suggests peak abundances of opportunistic species, however, the mechanism behind this is not clear. Nevertheless, the short duration, and the one-time occurrence, of the "high-productivity event" make it unlikely that the event is the accumulation of a long term climatic evolution.

\subsection{Conclusions}

To have a more accurate knowledge on the effects of dissolution, two dissolution indexes based on the fragmentation ratio of two individual species, Calcidiscus leptoporus and Coccolithus pelagicus $(6-10 \mu \mathrm{m})$, were calculated. These indexes, DL for C. leptoporus and DP for C. pelagicus $(6-10 \mu \mathrm{m})$, represent the ratio between the complete individuals and fragments of each species. The ratios ranged from 0 to 1 , with 0 representing a perfectly preserved assemblage. These dissolution indexes revealed that dissolution did not significantly affect the nannofossil signal

Analysis of the calcareous nannofossil assemblages revealed four different intervals, each with specific oceanographic conditions:

Interval I (3.14-2.82 Ma) is characterized by high coccolithophore productivity. Small placoliths dominate the assemblage with an average contribution above $80 \%$. C. pelagicus $(6-10 \mu \mathrm{m})$ has reduced abundances, interpreted as being related to higher SST's. A southward displacement of the oceanic fronts is inferred for this period. However, the nannofossil assemblage indicates that despite southward movement of the oceanic fronts, ODP site 1090 remained in the SAZ.

Interval II (2.72-2.2 Ma) has reduced NAR values and C. pelagicus $(6-10 \mu \mathrm{m})$ has a strongly increasing abundance, related to colder SST's after 2.82 Ma. We hypothesize that the closure of the CAS affected our study area, resulting in lower SST's accompanied with a northward movement of the frontal system. The interval between 2.44 and $2.34 \mathrm{Ma}$, with low C. pelagicus $(6-10 \mu \mathrm{m})$ abundances and high diversity is interpreted as a warm event (WP1), suggesting temporal subtropical-like conditions linked to a temporal 
southward movement of the frontal system. At a sub-orbital scale, higher productivity is observed during glacial terminations, believed to be caused by a higher input of nutrients caused by enhanced wind activity during glacial periods, enhancing mixing of the upper water column. The species composition shows G-IG variations with $C$. pelagicus $(6-10 \mu \mathrm{m})$ being more abundant during glacials and the small placoliths during interglacials. Our dissolution proxies, mainly DP, show that certain glacial stages (MIS 104, 100 and 98) are characterized by enhanced coccolithophore dissolution that have been linked to glacial expansion of SCW.

Interval III (2.2-2-02 Ma), where all taxa have similar proportions, indicates stable conditions in the upper water column. The interval between 2.14 and $2.0 \mathrm{Ma}$ (WP2), characterized by pulses of warm species is consistent with a southward movement of the oceanic fronts, with ODP site 1090 remaining in the SAZ.

Interval IV (2.02-1.8 Ma) has a coccolithophore assemblage similar to interval I, suggesting that the position of the oceanic fronts was similar as during interval I.

The fragmentation ratios of $C$. pelagicus and $C$. leptoporus, here also used to infer Late Pliocene deepwater circulation, suggest and increased preservation after 2.2 Ma that has been linked to a stronger NCW circulation in the South Atlantic. Correlation of the dissolution proxies with G-IG dynamics reveals that there is no consistent relation between both parameters.

An anomalous high abundance of the small placoliths was observed around 2.49 $\mathrm{Ma}$ (MIS 99) and has been interpreted as a short period of higher nutrients concentration and/or more vigorous mixing of the superficial water column. The timing and the short duration $(9 \mathrm{ka})$ of this event, might suggest that the high nutrient concentrations at ODP site 1090 could be linked to the deposition of large quantities of dust during the shock wave generated by the impact. However, there exist uncertainties about how long the particles can persist in the atmosphere and the exact relation between our anomaly and the Eltanin impact, if existent, remains elusive.

\section{Appendix A. Taxonomic appendix}

\section{Calcareous nannofossils}

Calcidiscus leptoporus (Murray and Blackman,1898) Loeblich and Tappan, 1978

Calcidiscus macintyrei (Bukry and Bramlette, 1969) Loeblich and Tappan, 1978 [Cyclococcolithus]

Coccolithus pelagicus (Wallich 1877) Schiller 1930 [Coccosphaera]

Discoaster pentaradiatus Tan, 1927

Discoaster surculus Martini and Bramlette, 1963

Discoaster variabilis Martini and Bramlette, 1963

Discoaster tamalis Kamptner, 1967

Florisphera profunda Okada \& Honjo 1973

Helicosphaera carteri (Wallich, 1877) Kamptner, 1954 [Coccosphaera]

Helicosphaera sellii (Bukry and Bramlette, 1969)

Oolithotus spp.

Pontosphaera spp.

Pseudoemiliania lacunosa (Kamptner, 1963) Gartner, 1969

Rhabdosphaera clavigera Murray \& Blackman 1898

Syracosphaera spp. 


\section{Morphological groups}

For the genus Reticulofenestra, we followed the morphometric subdivision established by Flores et al. (1995), considering 4 categories (VSR, SR, MR, LR). The term very small Reticulofenestra (VSR) is used for all specimens smaller than $3 \mu \mathrm{m}$, this group would be equivalent with Reticulofenestra minuta Roth, 1970. Small Reticulofenestra (SR) are all specimens between 3 and $5 \mu \mathrm{m}$. This group includes Reticulofenestra producta Kamptner, Reticulofenestra minutula Gartner, 1967 Haq and Berggren, 1978 [Coccolithus] and Reticulofenestra baqii Backman, 1978. The term medium Reticulofenestra refers to those specimens between 5-7 $\mu \mathrm{m}$, equivalent with: R. minutula, R. haqui, R. perplexa (Burns, 1975) Wise, $1983=$ D. antarcticus Haq. Large Reticulofenestra (LR) are larger than $7 \mathrm{~mm}$ and are equivalent with Reticulofenestra pseudoumbilicus (Gartner, 1967) Gartner, 1969 [Coccolithus].

For the genus Gephyrocapsa, specimens smaller than $3 \mu \mathrm{m}$ were grouped as small Gephyrocapsa, as in Flores et al. (1999). For the late Pliocene this group includes Gephyrocapsa aperta Kamptner, 1963, Gephyrocapsa sinuosa Hay \& Baudry (1973) and the Gephyrocapsa protobuxleyi - morphotype (Samtleben, 1980). Specimens larger than $3 \mu \mathrm{m}$ will be named Medium Gephyrocapsa. This group consists of individuals of Gephyrocapsa margerelii Bréhéret. 


\section{ChAPTER 8: MONITORING FLUCTUATIONS OF THE SUBTROPICAL FRONT IN THE TASMAN SEA BETWEEN 3.45 AND 2.45 Ma (ODP SITE 1172)}

Ballegeer, A.M., Flores, J.A., Sierro, F.J. and Andersen, N.

submitted to Paleogeography, Paleoclimatology, Paleoecology

8.1. Introduction

8.2. Regional setting

8.3. Material and methods

8.3.1. Material

8.3.2. Sample preparation and counting technique

8.4. Age Model

8.4.1. Magnetostratigraphy

8.4.2. Oxygen isotope stratigraphy

8.5. Preservation and dissolution index

8.6. Results and discussion

8.6.1. Calcareous nannofossil assemblages

8.6.2. Nannoplankton assemblages between 3.45 and $2.45 \mathrm{Ma}$

8.6.3. Glacial-interglacial variability

8.6.4. Isotopic stage $\mathrm{G} 7$

8.6.5. Trends in small Noelaerbabdaceae

8.7. Conclusions 



\title{
CHAPTER 8:MONITORING FLUCTUATIONS OF THE SUBTROPICAL FRONT IN THE TASMAN SEA BETWEEN 3.45 AND 2.45 MA (ODP SITE 1172).
}

\author{
Anne-Marie Ballegeer ${ }^{1 * *}$, José A. Flores ${ }^{1}$, Francisco J. Sierro ${ }^{1}$ and Nils Andersen ${ }^{2}$ \\ 1 Área de Paleontología, Departamento de Geología, Universidad de Salamanca, 37008 Salamanca, \\ Spain. \\ ${ }^{2}$ Leibniz Laboratory for Radiometric Dating and Isotope Research, Christian-Albrechts Universität \\ zu Kiel, Max-Eyth-Str. 11, 24118 Kiel, Germany
}

\begin{abstract}
Calcareous nannoplankton assemblages and benthic $\delta^{18} \mathrm{O}$ isotopes of Pliocene deep-sea sediments of ODP site 1172 (East of Tasmania) have been studied to improve our knowledge of the Southern Ocean paleoceanography. Our study site is located just north of the Subtropical Front (STF), an ideal setting to monitor migrations of the STF during our study period, between 3.45 and $2.45 \mathrm{Ma}$.

The assemblage identified at ODP site 1172 has been interpreted as characteristic for the transitional zone water mass, located south of the STF, based on: (i) the low abundances $(<1 \%)$ of subtropical taxa, (ii) relatively high percentages of Coccolithus pelagicus, a subpolar type species, (iii) abundances from 2-10\% of Calcidiscus leptoporus, a species that frequently inhabits the zone south of the STF and (iv) the high abundances of small Noelaerbabdaceae which at present dominates the zone south of the STF. Across our interval the calcareous nannofossils manifest clear glacial-interglacial variability. We have identified two different assemblages: a cold-water (glacial) assemblage with high percentages of $C$. pelagicus and a warm-water (interglacial) assemblage characterized by higher abundances of $C$. leptoporus and Helicosphaera carteri. The warm-water assemblage dominates before $3.1 \mathrm{Ma}$ while the following period is characterized with short alternations of the warm- and cold-water assemblage, in concordance with global cooling trends. Around $2.75 \mathrm{Ma}$, the interglacial stage G7 is characterized by anomalous low temperatures which most likely are linked to definite closure of the Central American Seaway (CAS), an event that is believed to have had global consequences. A gradual increase of very small Reticulofenestra across our section marks a significant trend in the small Noelaerbabdaceae species group and has been linked to a general enhanced mixing of the water column in agreement with previous studies. It is suggested that a rapid decline of small Gephyrocapsa after isotopic stage G7 might be related to the cooling observed in our study site after the closure of the CAS.
\end{abstract}

Keywords: calcareous nannoplankton; paleoceanography; Pliocene; Southern Ocean

\subsection{Introduction}

The Southern Ocean plays a major role in the oceanic thermohaline circulation which also has an important influence on the global climate (Ansorge et al., 2005). One of the most significant oceanographic features of the Southern Ocean is the Antarctic Circumpolar Current (ACC) which connects all ocean basins and is characterized by important temperature and salinity gradients, also known as oceanic fronts (Orsi et al., 1995; Rintoul et al., 2001). Traditionally, three circumpolar fronts can be distinguished (from north to south): the Subtropical Front (STF), the Subantarctic Front (SAF) and the Polar Front (PF) (Belkin and Gordon, 1996; Orsi et al., 1995). It is well established that during the Pleistocene these fronts have migrated 
north during glacials and south during interglacials, mimicking the seasonal movement seen today (Wells and Okada, 1996; Wells and Connell, 1997). The zones between the oceanic fronts have relatively uniform water mass properties and every zone has its own characteristic phytoplankton community (Sokolov and Rintoul, 2002). The analysis of the different phytoplankton groups (foraminifera, diatoms or coccolithophores) preserved in the sediments has been widely used to infer the paleoposition and the movement of the oceanic fronts of the Southern Ocean (Cortese and Gersonde, 2008; Findlay and Flores, 2000; Hiramatsu and De Deckker, 1997; Sabaa et al., 2004; Wells and Okada, 1997). Most of these studies however have focused on the Pleistocene climate variations and little is known about the climate evolution during the Pliocene. In the present study, we pretend to provide new insights in the climate evolution of this particular time period, especially since it is the most recent interval in earth history when climate was significantly warmer than today (Crowley, 1996; Dowsett et al., 1996) and may serve as a geological analogue that can help to predict the future climate (Haywood et al., 2009; Salzmann et al., 2009). For this, we have analyzed the benthic isotopes and the calcareous nannofossils of a 1-Ma (3.45-2.45 Ma) long sediment record recovered in the Tasman Sea (Southwest Pacific). Calcareous nannofossils have proved to be a reliable proxy for the properties of surface waters (McIntyre and Bé, 1967; Thierstein and Young, 2004; Winter and Siesser, 1994) and thus form an excellent tool to infer the paleoposition of the oceanic fronts. The objectives of our research are: (1) to infer the paleoposition of the STF and its movements between 3.45 and $2.45 \mathrm{Ma}$, (2) to study the glacial and interglacial coccolithophore variability.

\subsection{Regional Setting}

ODP site 1172 is located on the flat western side of the East Tasman Plateau (Tasman Sea), at $44^{\circ} 57^{\prime} \mathrm{S}$ and $149^{\circ} 55^{\prime} \mathrm{E}$ (Fig. 8.1). The core is located just north of the present STF, at present situated at $45-47^{\circ} \mathrm{S}$. The STF, which is the dominant feature of the area, is a dynamic boundary between the relatively warm and salty Tasman Sea and the cool, fresh subantarctic waters (SAW) of the Southern Ocean (Sokolov and Rintoul, 2002). For paleoceanographic reconstructions the STF in this area is identified by a temperature gradient of $\sim 4^{\circ} \mathrm{C}$ across $1^{\circ}$ latitude (Nürnberg and Groeneveld, 2006; Sikes et al., 2002). The study area is influenced by the southward flowing eddy field that is formed at the Tasman Front $\left(\sim 30^{\circ} \mathrm{S}\right)$ when the East Australian Current (EAC) deflects its flow eastwards (Fig. 8.1). A residue of the EAC transport moves southward along the coast as far as Tasmania and then turns west into the eastern Indian Ocean (Tasman Outflow) and has an important impact on the global ocean circulation (Speich et al., 2002). South of the STF, the Antarctic Circumpolar Current (ACC) is the dominant feature of the surface circulation (Fig. 8.1).

ODP site 1172 is recovered at $2620 \mathrm{~m}$ water depth (Shipboard Scientific Party, 2001), above the present lysocline that is estimated at $3600 \mathrm{~m}$ in the west Tasman Sea (Martinez, 1994). The Tasman Sea is fed by the Antarctic Bottom Water (AABW) that comes from the northern flank of the ACC. Above the AABW, flows the Antarctic Intermediate Water (AAIW) which enters the Tasman Sea along two paths. The AAIW with minimum salinity less than $34.4 \%$ enters from the south, taking the shortest route from the Polar Front. Another AAIW supply comes from the East and enters from the north in the Tasman Sea (Tomzack and Godfrey, 2003). 


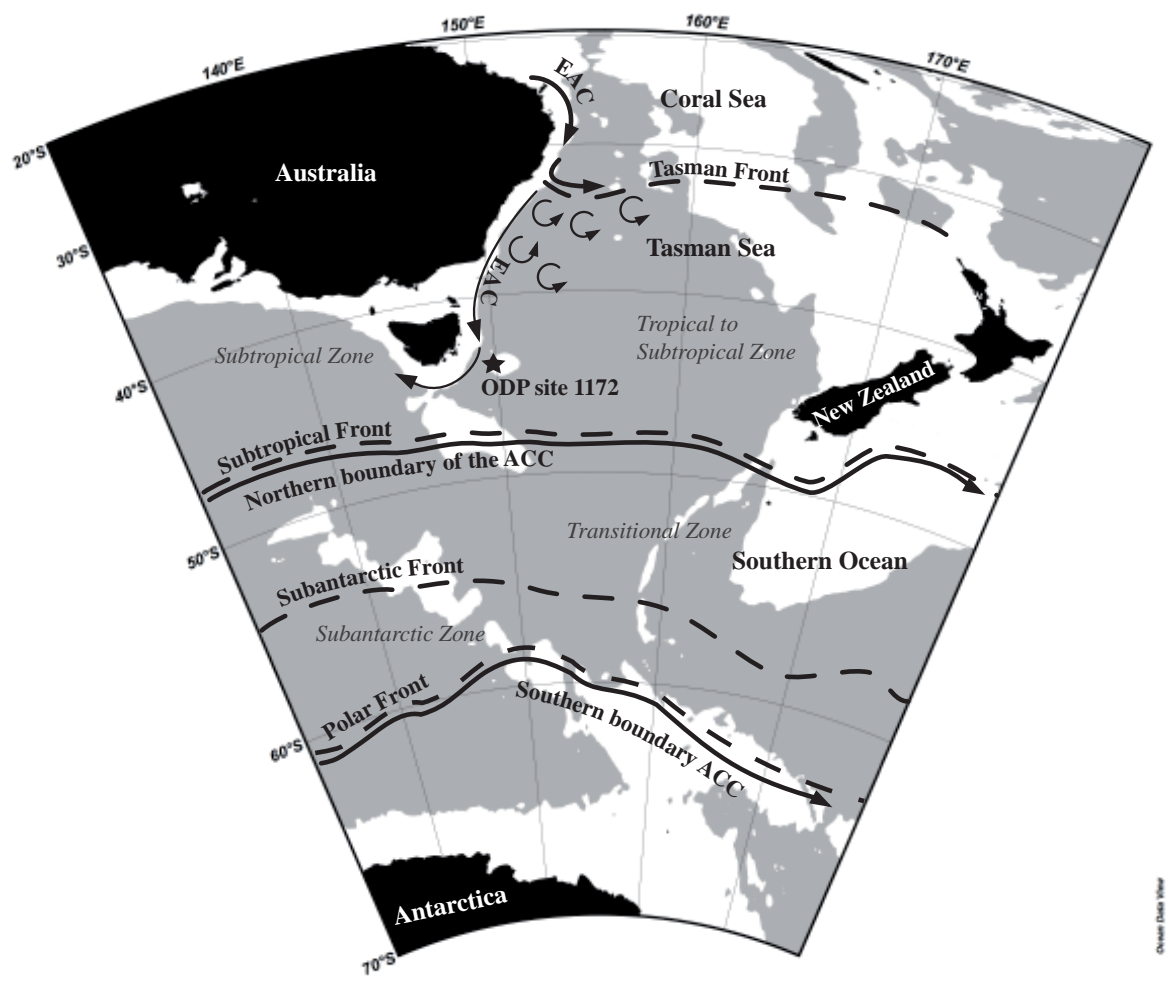

Fig. 8.1. Location of ODP site 1172 and dominant oceanographic features of the study area. From north to south the following fronts can be distinguished: the Tasman Front, the Subtropical Front, the Subantarctic Front and the Polar Front. The most important surface currents that affect the study area are (i) the East Australian Current (EAC) and its eddy field that flow south along the Australian coast and (ii) the Antarctic Circumpolar Current (ACC). The different biogeographic zones of Findlay \& Giraudeau (2002) are indicate in italic. The ocean bathymetry is divided in areas with depths $>3000 \mathrm{~m}$ (gray) and areas $<3000 \mathrm{~m}$ (white). The map was elaborated with the Ocean Data View software (Schlitzer, 2011).

\subsection{Material \& Methods}

\subsubsection{Material}

Here we study material from ODP site 1172 recovered during Leg 189 (Exon et al., 2001). A total of 175 samples were analyzed, between 31 and 47.4 meters composite depth (mcd) (core $3 \mathrm{H}, 4 \mathrm{H}$ and $5 \mathrm{H}$ from hole $1172 \mathrm{~A}$ and core $5 \mathrm{H}$ from hole 1172B). Samples were taken every $10 \mathrm{~cm}$ that according to the proposed age model (section 4 ) represent $\sim 0.006 \mathrm{Ma}$. The lithologies of the sediments are white foraminifer nannofossil oozes and foraminifer-bearing nannofossil oozes and bioturbation is only rarely seen (Shipboard Scientific Party, 2001).

\subsubsection{Methods}

\section{Nannofossil preparation and counting techniques}

Coccolith slides were prepared using the decantation method of Flores and Sierro (1997). For the preparation of each slide, 0.2 or $0.1 \mathrm{~g}$. of sediment was used as initial weight. This procedure allows calculation of the number of coccoliths per gram of sediment. Bulk densities were taken from the ODP report (Exon et al., 2004), and linear sedimentation rates were calculated using the age-depth points displayed in Table 8.1. The 
nannofossil accumulation rates (NAR; coccoliths $\mathrm{cm}^{-2} \mathrm{ka}^{-1}$ ) can be estimated after consideration of density and the linear sedimentation rate. The NAR values are used as a proxy for coccolithophore production (Flores et al., 2003).

Counting was done at 1000x magnification using a polarized light microscope (Nikon eclipse 80i). Identification was done up to species level for the majority of nannofossils, but some taxa were grouped into morphological groups (see Taxonomy). For counting: (i) A first analysis was carried out counting all nannofossil observed in random visual fields of homogenously distributed samples, until a total number of at least 400 liths was reached; (ii) Because a small number of taxa dominated the assemblage a second counting procedure was realized in order to estimate the abundance of the rare specimens. A species was considered rare if its general abundance was below 5\% after the first count. During the second count, at least 25 visual fields were taken into consideration and all the rare species were counted. After both procedures we were able to calculate the total NAR and the relative abundance (\%) and NAR of all the individual species/taxa.

\section{Taxonomy}

A total of 14 species and 5 morphological groups have been identified (See Appendix). Morphological groups based on coccolith size were used for the genus Reticulofenestra and Gephyrocapsa. For the genus Reticulofenestra we used the size-divisions proposed by Flores et al. (1995). The smallest size group, Reticulofenestra spp. $<3 \mu \mathrm{m}$, labeled Very Small Reticulofenestra (VSR) was the only group with significant abundances. For the genus Gephyrocapsa we used the term small Gephyrocapsa (SG) for specimens of this genus $<3 \mu \mathrm{m}$. In some occasions the term small Noelaerbabdaceae will be used to refer to SG and VSR together. For Calcidiscus leptoporus we used the traditional classification of the Pliocene where C. leptoporus includes individuals between 3-10 $\mu \mathrm{m}$ with a circular to sub-circular form and a closed central area (Backman and Shackleton, 1983). Additionally, a number of species with very low abundances $(<1 \%)$ and ecological preference for warm waters were grouped as "subtropical taxa". This group includes Pontosphaera spp., Rabdosphaera clavigera, Umbilicosphaera spp., Calciosolenia sp., Syracosphaera spp. and Ceratolithus sp.

\section{Isotopic measurements}

Stable isotopic analyses from both planktonic as benthic foraminifera were preformed every $10 \mathrm{~cm}$. Samples for isotopic analyses were washed over a $63 \mu \mathrm{m}$ sieve and the residues were dried and dry-sieved again using a $150 \mu \mathrm{m}$ sieve. For the benthic foraminifera, a minimum of 5 individuals of Cibicidoides wuellerstorfi from the fraction $>150 \mu \mathrm{m}$ were picked. In absence of sufficient individuals of C. wuellerstorfi, either Cibicidoides spp. or Uvigerina perigrena were picked. The values of $U$. perigrena were corrected using a correction factor -0.64 for $\delta^{18} \mathrm{O}$ (Shackleton and Opdyke, 1973). Foraminiferal test were soaked in $15 \% \mathrm{H}_{2} \mathrm{O}_{2}$ to remove organic matter, and cleaned sonically in methanol to remove fine-grained particles. Oxygen and carbon isotopic values from Site 1172 were measured at Christian-Albrechts University of Kiel using a Finnigan MAT 251 mass spectrometer with an analytical error better than $\pm 0.07 \%$ for $\delta^{18} \mathrm{O}$ measurements. All isotope results are reported in standard delta notation relative to V-PDB (Coplen, 1996). 


\subsection{Age Model}

\subsubsection{Magnetostratigraphy}

The major paleomagnetic chrons and subchrons of ODP site 1172 were identified by Stickley et al. (2004). Our nannofossil biostratigraphy revealed that the chron between 21.78 and 19.32 mcd, identified by Stickley et al. (2004) as Olduvai (C2n), corresponds with the Jaramillo chron (C1r.1r). Two well established biostratigraphic evidences support this reinterpretation: (i) The first common occurrence of $R$. asanoi, identified at $22.15 \mathrm{mcd}$, marks MIS 31(Raffi et al., 2006); (ii) The first occurrence of G. omega/reentrance of Gephyrocapsa $>4 \mu \mathrm{m}$, identified at $20.35 \mathrm{mcd}$, assures us that the section reaches up to MIS 27 (Raffi et al., 2006) (Fig. 8.2). The occurrence of discoasterids is low and discontinuous but the approximation of the last occurrence of D. surculus enabled us to verify the correct identification of Stickley et al. (2004) of the top of chron C2An.1n. Isotopic stage M2, identified in the benthic $\delta^{18} \mathrm{O}$ record of ODP site 1172, affirms the identification of the top of C2An.3n of Stickley et al. (2004). This new interpretation of the magnetic polarity, shown in Fig. 8.2, reveals a discontinuous sediment record since the olduvai chron (C2n) is not identified at ODP site 1172.

\subsubsection{Oxygen isotope stratigraphy}

The chronologies of ODP site 1172 were derived by correlation of the benthic foraminiferal oxygen isotopic signal with the benthic LR04-stack (Lisiecki and Raymo, 2005) using the program Analyseries (Paillard et al., 1996). Based on the $\delta^{18} \mathrm{O}$ curve, the nannofossil biostratigraphy and the magnetostratigraphy, 14 age control points were identified and have been translated into absolute ages (Table 8.1). The estimated average sedimentation rate based on the age-depth relationship is $2.55 \mathrm{~cm} / \mathrm{ka}$, varying from $1.13 \mathrm{~cm} / \mathrm{ka}$ to $6.67 \mathrm{~cm} / \mathrm{ka}$. The correlation between our $\delta^{18} \mathrm{O}$ record and the LR04-stack is good between 3.45 and 2.45 $\mathrm{Ma}$, although the resolution of our record did not allow the identification of all individual marine isotopic stages (Fig. 8.2).

Table 8.1

\begin{tabular}{|c|c|c|c|}
\hline Depth (mcd) & Age (Ma) & Method & $\begin{array}{l}\text { Marine Isotope Stage } \\
\text { (MIS) / Chron-subchron }\end{array}$ \\
\hline 31.20 & 2.49 & $\delta^{18} \mathrm{O}$ & MIS 98 \\
\hline 31.90 & 2.53 & $\delta^{18} \mathrm{O}$ & MIS 100 \\
\hline 32.40 & 2.57 & $\delta^{18} \mathrm{O}$ & MIS 102 \\
\hline 32.80 & 2.60 & $\delta^{18} \mathrm{O}$ & MIS 104 \\
\hline 32.82 & 2.61 & Paleomagnetism & $\mathrm{C} 2 \mathrm{An} .1 \mathrm{n}(\mathrm{t})$ \\
\hline 35.40 & 2.72 & $\delta^{18} \mathrm{O}$ & G6 \\
\hline 36.88 & 2.81 & $\delta^{18} \mathrm{O}$ & G10 \\
\hline 37.28 & 2.83 & $\delta^{18} \mathrm{O}$ & G11 \\
\hline 39.84 & 3.05 & Paleomagnetism & $\mathrm{C} 2 \mathrm{An} .1 \mathrm{r}(\mathrm{t})$ \\
\hline 39.92 & 3.05 & $\delta^{18} \mathrm{O}$ & G22 \\
\hline 41.54 & 3.13 & Paleomagnetism & C2An.1r (b) \\
\hline 41.72 & 3.14 & $\delta^{18} \mathrm{O}$ & KM2 \\
\hline 43.14 & 3.21 & Paleomagnetism & $\mathrm{C} 2 \mathrm{An} \cdot 2 \mathrm{r}(\mathrm{t})$ \\
\hline 44.82 & 3.30 & $\delta^{18} \mathrm{O}$ & M2 \\
\hline
\end{tabular}

Table 8.1. Age-depth points chosen for ODP site 1172. 


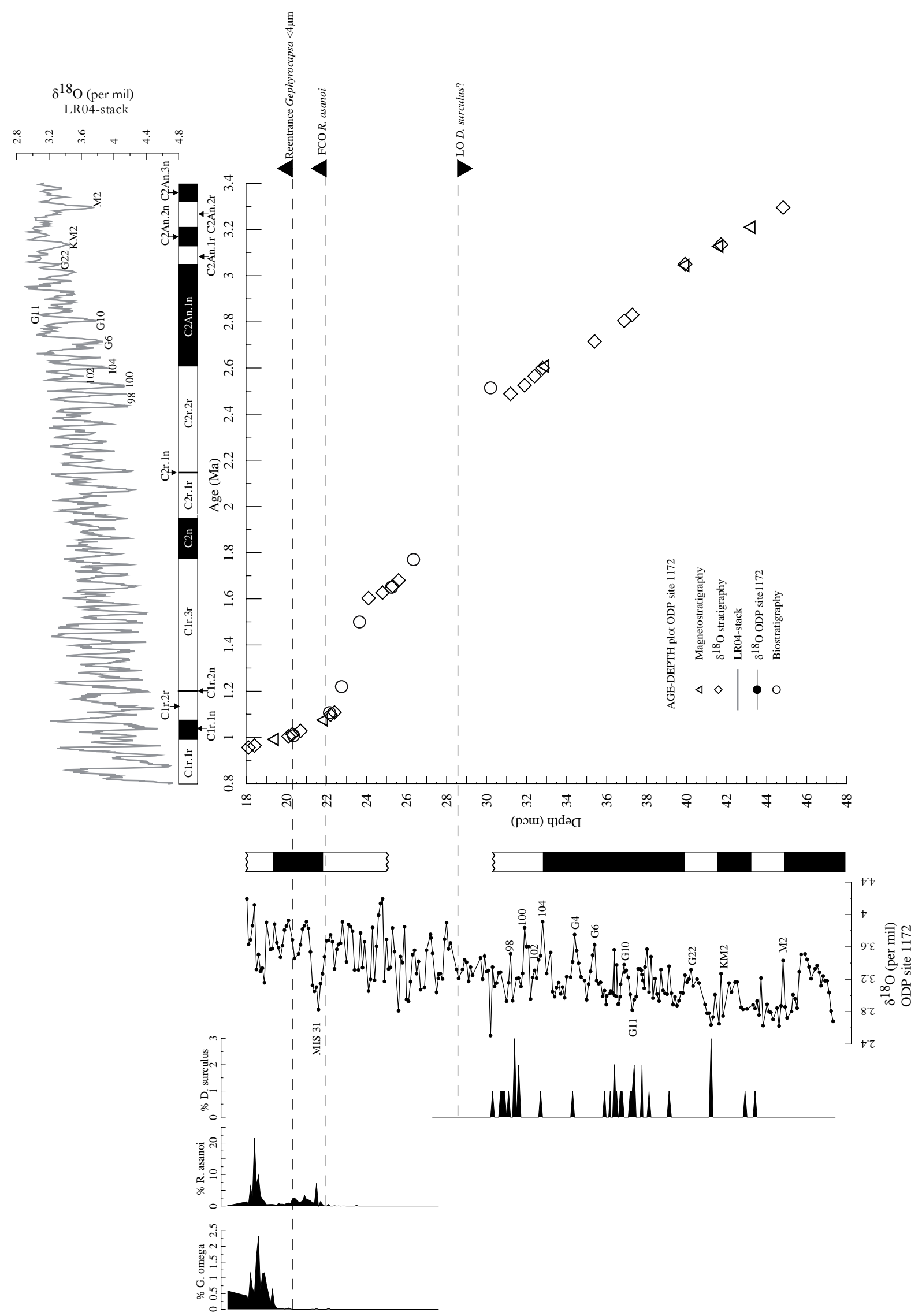

Fig. 8.2. Age model ODP site 1172: The age-depth points were based on: Significant biostratigraphic events (LO D. surculus, FCO R. asanoi and FO G.omega), paleomagnetic reversals published by Stickley et al. (2004) and oxygen isotope stratigraphy after comparasion with the LR04-stack (Lisiecki \& Raymo, 2005). 


\subsection{Preservation and dissolution index}

Following the criteria established by Flores et al. (2003), the preservation of the nannofossils is moderate to good. The central area of species such as Pontosphaera spp. and Syracosphaera spp. was not always preserved suggesting a moderate degree of dissolution in some samples. The continuous presence of more fragile species such as VSR and SG, indicates that the dissolution is not severe and that the assemblage may be considered as representative for the surface assemblage. Additionally, we have calculated a dissolution index based on the fragmentation of the coccolithophore C. leptoporus. We quantified the disarticulation of the proximal and the distal shield (DS) of C leptoporus, as proposed by Matsuoka (1990) and successfully used by other authors (Bolton et al., 2010a; Findlay and Giraudeau, 2002). Instead of determining the \% of complete individuals (CI) as Matsouka (1990), we used the following equation:

$$
D L=D S /(D S+C I)
$$

The resulting index, DL, ranges between 0 and 1, with 0 representing a sample with only complete individuals (Fig. 8.3). The absence of prolonged high values of the dissolution index DL further confirms the moderate to good preservation of the assemblage.

\subsection{Results and discussion}

\subsubsection{Calcareous nannofossil assemblage and abundances}

The total NAR fluctuates between 1.9.10 and 4.53.107 coccoliths $\mathrm{cm}^{-2} \mathrm{ka}^{-1}$ and shows strong variations along the record. Continuous relatively low values are recorded between 3.05 and 2.75 Ma. A sharp increase of the NAR $\sim 2.73 \mathrm{Ma}$ is registered and is followed by a gradual decrease (Fig. 8.3).

The two dominant species in ODP site 1172, VSR and SG, recorded percentages between 14.04 and 77.05\% and 0 and $70.68 \%$, respectively. SG is abundant before $3.1 \mathrm{Ma}$, while VSR is more abundant after $3.1 \mathrm{Ma}$. After 2.65 Ma, SG has abundances below $10 \%$.

The subordinate taxa C. pelagicus and C. leptoporus show highest abundances: from 5 to $69.5 \%$ and 2.1 to 32.7\% (excluding SG and VSR), respectively. Maxima of C. pelagicus (both relative abundance and NAR) coincide with high $\delta^{18} \mathrm{O}$ values, except between 2.73 and $2.76 \mathrm{Ma}$, where high abundances coincide with low $\delta^{18} \mathrm{O}$ values. C. leptoporus shows a negative covariance with respect to $C$. pelagicus and its maximum abundances (both relative abundance and NAR) coincide with minima of C. pelagicus. Helicosphaera carteri, with abundances between 0 and 2.5\%, has abundance variations parallel to those of C. leptoporus. A distinct maximum (both relative abundance and NAR) of this species is observed during G5. The group of subtropical taxa has very low abundances, fluctuating below 1\% of the subordinate taxa. Maxima of this group are observed during periods with low $\delta^{18} \mathrm{O}$ values.

\subsubsection{Nannoplankton assemblage between 3.45 and $2.45 \mathrm{Ma}$.}

The nannoplankton assemblage at ODP site 1172 is characterized by: high percentages of small Noelaerhabdaceae (>50\%), moderate abundances of C. pelagicus (2-38\%) and C. leptoporus (3-11\%) and low abundances of $H$. carteri $(<4 \%)$ and subtropical taxa $(<1 \%)$ (Table 8.2$)$. These abundances suggest that 
the Pliocene nannofossil assemblage can be interpreted as equivalent to the transitional-zone assemblage of Findlay and Giraudeau (2000), implying a northward position of the STF with respect to the present day position. Despite the observed species fluctuations, our data suggest that none of the fronts (STF and SAF) moved over ODP site 1172 between 3.45 and $2.45 \mathrm{Ma}$. This interpretation is based on several criteria. First, low abundance $(<1 \%)$ of subtropical taxa, such as e.g. Syracosphaeara spp., Calciosolenia spp., that are relatively abundant $(>10 \%)$ in the current tropical-subtropical zone (Findlay and Giraudeau, 2000), indicate a continuous northward position of the STF. Second, relatively high percentages of $C$. pelagicus, which is known as subpolar species (McIntyre et al., 1970; Okada and McIntyre, 1977), make it unlikely that the STF was positioned south of the present day position. Third, the continuous presence of C. leptoporus, a species absent in the present day subtropical-tropical zone (Findlay and Giraudeau, 2000) and frequent within the Subantarcti zone (Boeckel et al., 2006; Eynaud et al., 1999) also indicates a transitional assemblage. Finally, VSR and SG have abundances of $50-70 \%$ throughout the whole interval which is more similar to the transitional assemblage than to the tropical-subtropical assemblage. Although VSR is an extinct group of taxa, scientists believe that these taxa occupied the ecological niche of Emiliania huxleyi (Flores and Sierro, 2007; Thierstein et al., 1977) and studies of extant coccolithophores indicate a strong increase in the abundance of E. huxleyi south of the STF reaching percentages $>80 \%$ (compared with $<50 \%$ north of the STF) (Findlay and Giraudeau, 2000; Mohan et al., 2008).

Table 8.2

Dominant taxa at ODP site 1172

Relative abundance ( $\%$ of the total assemblage)

\begin{tabular}{lrrr}
\hline Taxon & Minimum & Maximum & Average \\
\hline VSR & 13 & 77.1 & 40.8 \\
SG & 0 & 70.7 & 26.7 \\
VSR+SG & 13 & 92.2 & 67.5 \\
C. pelagicus & 2 & 38 & 8.5 \\
C. leptoporus & 0.5 & 10.9 & 3.4 \\
H. carteri & 0 & 0.9 & 0.2 \\
Subtropical Taxa & 0 & 0.5 & 0.1
\end{tabular}

Subordinate taxa at ODP site 1172

Relative abundance (\% excluding SG+VSR)

\begin{tabular}{lrrr}
\hline Taxon & Minimum & Maximum & Average \\
\hline C. pelagicus & 5 & 69.5 & 26.1 \\
C. leptoporus & 2.4 & 38.1 & 11.2 \\
H. carteri & 0 & 2.5 & 0.5 \\
Subtropical Taxa & 0 & 1 & 0.2
\end{tabular}

Table 8.2. Overview of the species composition of the calcareous nannofossil assemblages registered at ODP site 1172 
At first, a more northward position of the oceanic fronts, especially before $3 \mathrm{Ma}$, seems unlikely giving the general consensus of a global warmer climate during the Mid Pliocene (Dowsett et al., 1996). The Mid Pliocene Warmth was characterized by a low equator to pole temperature gradient and a weak atmospheric circulation (Crowley, 1996). The lack of steep temperature gradients along the Southern Ocean would allow the occurrence of a broader area of transitional waters which would be characterized with intermediate temperatures (lower than subtropical waters but slightly higher than the subpolar waters south of the SAF). We suggest that the northward position of the STF between 3.45 and 2.45 Ma was linked to an expansion of the transitional zone. At present, the eddy-field of the EAC helps to maintain the southerly position of the STF (Fig. 8.1). Our results suggest that during our study interval the EAC and its warm-core eddies were, in contrast with the Pleistocene (Nürnberg and Groeneveld, 2006), weaker or absent, allowing the STF to be positioned more north. This is not unlikely since the closure of the Indonesian Gateway, 5-3 Ma, largely affected the strength of the EAC. Modelling studies suggested a distinct weakening of the warm EAC upon closing of the Indonesian Gateway (Godfrey, 1996; Hirst and Godfrey, 1993). A direct relation between the strenght of the EAC and the position of the oceanic fronts has also been suggested by Wei (1998), who postulates that a southward shift of the Tasman Front at 4.4 Ma might have been linked to the intensification of the EAC. Our interpretation for the position of the STF during the Pliocene is supported by previous studies realized in this area (Gallagher et al., 2003; Sabaa et al., 2004). Significantly, south of New Zealand a northward migration of the STF and a southward position of the Antarctic Polar Front were inferred, suggesting the existence of a broader area with cool subpolar waters (Sabaa et al., 2004). A reduced strength of the EAC and a more northward postion of the STF $\left(\sim 40^{\circ} \mathrm{S}\right)$ for the period between 4 and $2 \mathrm{Ma}$ is suggested by Gallagher et al. (2003).

\subsubsection{Glacial-interglacial variability}

The species composition of the calcareous nannofossil assemblage shows significant variations along our study record that can be related to the glacial-interglacial (G-IG) variability observed in the $\delta^{18} \mathrm{O}$ record. In our record maxima of $C$. pelagicus coincide with glacial periods (except during G7), in agreement with previous studies that described C. pelagicus, as a cold-water proxy (Geitzenauer, 1972; Geitzenauer et al., 1976; McIntyre and Bé, 1967; Okada and McIntyre, 1977; Okada and McIntyre, 1979; Raffi and Rio, 1981), successfully used to identify Quaternary glacial periods in the South Pacific (Findlay and Flores, 2000; Wells and Okada, 1996; Wells and Okada, 1997). We found a negative covariance between C. leptoporus and $C$. pelagicus (Fig. 8.3), suggesting that this species prefers relatively warmer waters (compared to $C$. pelagicus) and is associated with interglacial periods (in agreement with Findlay and Flores, 2000; Flores et al., 1999; Geitzenauer, 1969; Wells and Okada, 1997). At ODP site 1172, similar trends of C. leptoporus an $H$. carteri, suggest that these species have similar ecological preferences, implying a positive relation between H. carteri and temperature. Our interpretation agrees with previous studies performed in this area (Findlay and Flores, 2000; Findlay and Giraudeau, 2002) but disagrees with studies from other areas of the Southern Hemisphere where high abundances of $H$. carteri coincide with high abundances of $C$. pelagicus and are related with higher nutrient concentrations (Cachão and Moita, 2000; Fincham and Winter, 1989; Giraudeau and Rogers, 1994). Based on the relative abundances of these key species (C. pelagicus, C. leptoporus and $H$. carteri) we have differentiated two different assemblages: a cold-water and a warm-water assemblage. The 


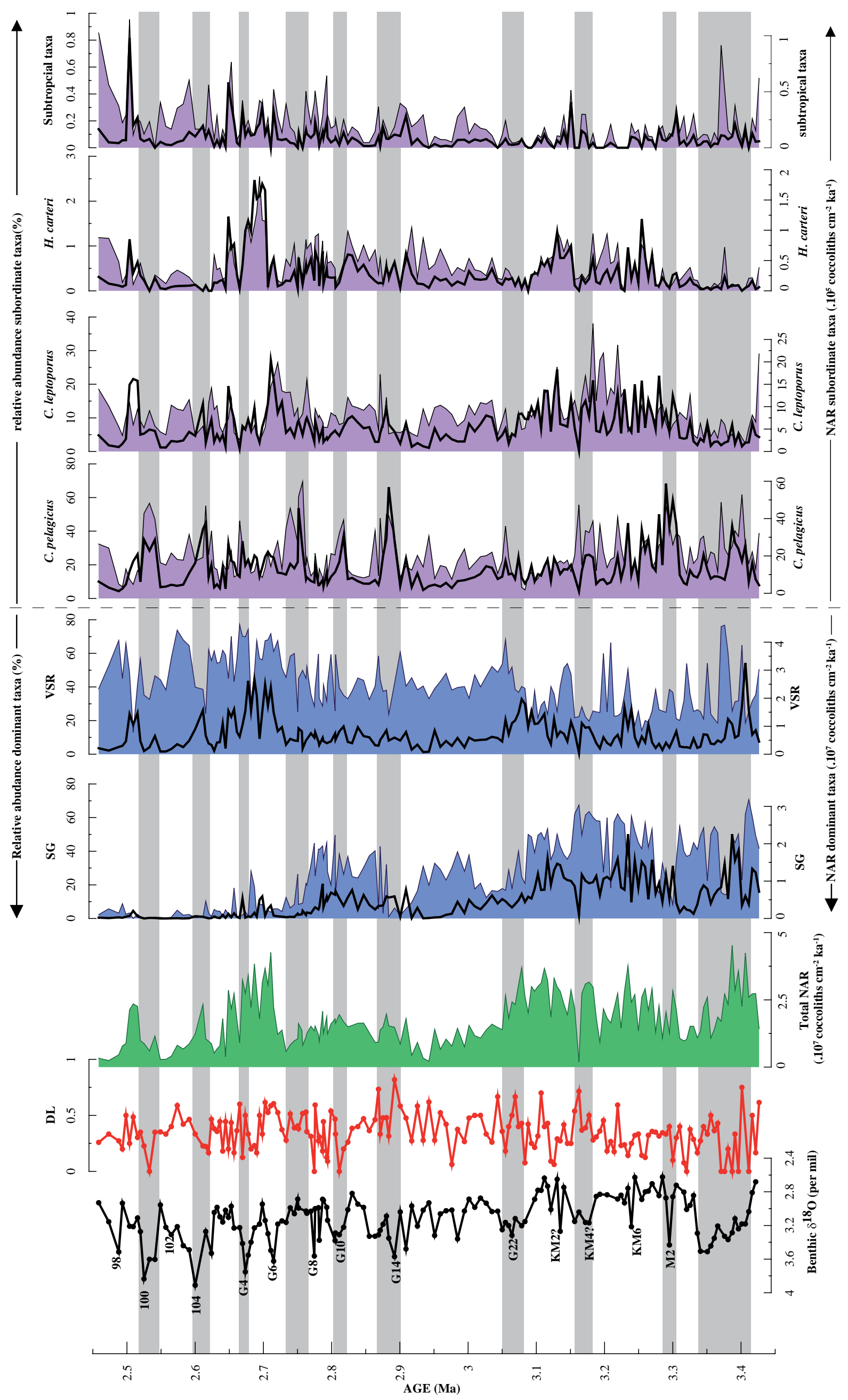


cold-water assemblage is characterized by relatively high $(>40 \%)$ abundances of $C$. pelagicus and relatively low abundances of $C$. leptoporus and $H$. carteri and is registered during glacials (except during G7). The warmwater assemblage has low abundances of $C$. pelagicus and relatively higher abundance of $C$. leptoporus and $H$. carteri and is associated with interglacial periods.

Despite the relatively low $\delta^{18} \mathrm{O}$ fluctuations before $\sim 2.9 \mathrm{Ma}$, a clear differentiation between a typical glacial (cold water) assemblage and an interglacial (warm water) assemblage has been observed. During this interval, the warm water assemblage predominates above the cold water assemblage. We suggest that short intervals with the cold water assemblage are associated with slight, northward migrations of the STF resulting in relatively cooler SST's at our study site. This interval (3.45-2.9 Ma) of relatively stable and warmer conditions is followed by an interval that is characterized by short-time alternations between the cold- and the warmwater assemblage and higher $\delta^{18} \mathrm{O}$ variations. It is important to keep in mind that despite moderate northsouth migrations of the STF along G-IG cycles, the front did not move over the study site (discussed in section 6.1). Our data indicate an important change in the G-IG dynamics around 2.9 Ma after which the G-IG cycles are similar to the Pleistocene. The paleoceanographic interpretation based on our nannofossil record is supported by the foraminifera assemblages recorded south of Australia (Gallagher et al., 2003). These authors registered the same transition, from dominant warm water assemblage towards alternating warm-cool assemblages, around $3 \mathrm{Ma}$. Our data indicate an important change in the glacial-interglacial dynamics at around 2.9 Ma when the glacial-interglacial cycles start to be similar to the Pleistocene and this is interpreted as an important cooling in the Tasman Sea. The cooling trend observed at ODP site 1172 coincides with global cooling, as indicated by Lisiecki and Raymo (2005), related to the closure of the Central America Seaway (CAS) and the development of the Northern Hemisphere ice sheet (Bartoli et al., 2005).

\subsubsection{Isotopic stage $\mathrm{G} 7$}

Despite the fairly good positive correlation between the abundances of $C$. pelagicus and the $\delta^{18} \mathrm{O}$ record, one exception on this pattern is observed during the isotopic stage G7 (2.73-2.76 Ma). This interval is characterized by peak abundances (relative and absolute) of $C$. pelagicus and low $\delta^{18} \mathrm{O}$ values, opposite to the rest of our record. At ODP site 1172, high abundances of C. pelagicus suggest relatively cold SST and a more northward position of the STF as discussed before. The timing of this "anomalous" cold interglacial coincides with the definite closure of the CAS (dated $\sim 2.74 \mathrm{Ma}$ ). GCM models suggest that the closure of the CAS significantly altered global latitudinal heat transport: relatively more heat was transported to the northern high latitudes compared to the southern hemisphere (Lunt et al., 2008) leading to a significant cooling of the Southern Ocean (Hodell et al., 1991; Karas et al., 2010; Sabaa et al., 2004). Exceptional cooling during the interglacial G7, linked to the closure of the CAS, would explain the high abundances of C. pelagicus and the more northward position of the STF during this interglacial.

Fig. 8.3. Nannofosssil abundances registered at ODP site 1172. Comparison of benthic $\delta^{18} \mathrm{O}$ record and the relative (\%; solid area) and absolute (NAR; coccoliths $\mathrm{cm}^{-2} \mathrm{ka}^{-1}$; black line) abundances of the most important taxa. The preservation is indicated by the dissolution index (DL) based on the disarticulation of the shields of C. leptoporus. 


\subsubsection{Trends in small Noelaerhabdaceae}

Some significant trends superimposed on the alternations of cold- and warm-water assemblages have been observed within the small Noelaerbabdaceae. SG exhibits a gradual decrease across our study interval: before 3.1 Ma, these taxa make up for more than $40 \%$ of the assemblage while after $3.1 \mathrm{Ma}$ they are gradually replaced by VSR. VSR is known to respond to upwelling and general higher nutrient concentrations (Aubry, 1992; Flores et al., 1995). We suggest that the increasing nutrient concentration in the upper water column, most likely related to enhanced mixing of the upper water column might have favored VSR above SG. The late Pliocene cooling has been interpreted as strong upwelling (Marlow et al., 2000) associated with stronger winds due to enhanced pole to equator temperature gradients (Dowsett and Willard, 1996). The increased abundance of VSR at our study site and the increased abundance of the foraminifer Globorotalia inflata, also an upwelling indicator, between 4 and $2.3 \mathrm{Ma}$ east of New Zealand (Sabaa et al., 2004) supports this. Additionally, our record reveals an episode of relatively rapid decline of SG during G7 ( 2.75 Ma) (Fig. 8.3). This coincides with important changes in the NAR values, suggesting that the rapid decline of SG might have been linked to environmental changes that also affected the total coccolithophore productivity. G7 is described as an anomalous cold interglacial period in the previous section. The cooler temperatures during this isotopic stage have been linked to the closure of the CAS. In this regard, we suggest that a sudden cooling, most likely linked to the definite closure of the CAS, may have contributed to the rapid decline of SG in our study area. Evolution plays an important role in the distribution of the different coccolithophore species along geological time. Despite the high abundance of small Noelaerbabdaceae in the fossil record, we know relatively little about these species which makes it difficult to interpret the variations between different species within this group. The fact, however, that rapid declines in the SG record are associated with important changes in the nannofossil assemblage supports the idea that this event might be driven by environmental changes.

\subsection{Conclusions}

The calcareous nannofossil assemblage identified between 2.45 and $3.45 \mathrm{Ma}$ at ODP site 1172 is characteristic for the trasitional zone, implying a continuous northward position of the STF with respect to ODP site 1172. This interpretation is based on: (i) Low abundance $<1 \%$ of subtropical taxa such as Syracosphaera spp. and Calciosolenia spp., (ii) relatively high abundances of C. pelagicus, a subpolar species, (iii) continuous intermediate abundances of $C$. leptoporus which is a species that frequently inhabits the zone south of the STF and (iv) abundances between 50 and $70 \%$ of small Noelaerhabdaceae, a group that dominates the zone south of the STF. We suggest that the northward position of the STF was linked to a weaker EAC, allowing a more northward position of the STF and leading to an expansion of the transitional zone.

Across our interval, the calcareous nannoplankton shows alternation between a typical cold-water assemblage and a warm-water assemblage related to the G-IG cylcicity observed in the $\delta^{18} \mathrm{O}$ record. The cold-water assemblage is characterized by high abundances of $C$. pelagicus, while the warm-water assemblage has high abundances of $C$. leptoporus and $H$. carteri. During interval before $\sim 2.9 \mathrm{Ma}$, the warm assemblage predominates, suggesting relatively stable and warm conditions. The occurrence of the cold water assemblage has been interpreted as moderate northward shifts of the STF during this period. After 2.9 Ma, short-time 
alternations between cold- and warm-water assemblage mark an important change in the G-IG dynamics which is in agreement with the global climate transition during the late Pliocene.

During isotopic stage G7 we have observed anomalous high abundance of $C$. pelagicus, indicating that this interglacial was characterized by relatively low temperatures. The timing of this, $\sim 2.75 \mathrm{Ma}$, leads to the idea that this cooling is related to the definite closure of the CAS dated at $\sim 2.74 \mathrm{Ma}$.

I

ndependently of the G-IG variability we observed a significant trend in the small Noelaerbabdaceae group: after 3.1 Ma, SG is gradually replaced by VSR. The increased abundance of VSR, described as an upwelling indicator, has been associated to enhanced mixing of the water column after 3.1 Ma linked to an intensification of the atmospheric circulation due to late Pliocene climate cooling causing an increased equator- to pole gradient. Additionally, we suggest that the cooling in the Tasman Sea caused by the closure of the CAS contributed to the rapid decline of SG observed in our record.

\section{Appendix A: Calcareous nannofossils}

Calcidiscus leptoporus (Murray and Blackman,1898) Loeblich and Tappan, 1978

Calcidiscus macintyrei (Bukry and Bramlette, 1969) Loeblich and Tappan, 1978 [Cyclococcolithus]

Calciosolenia sp. Gran 1912 emend. Young et al. 2003

Ceratolithus sp. Kamptner, 1950

Coccolithus pelagicus (Wallich 1877) Schiller 1930 [Coccosphaera]

Discoaster pentaradiatus Tan, 1927

Discoaster surculus Martini and Bramlette, 1963

Discoaster variabilis Martini and Bramlette, 1963

Discoaster tamalis Kamptner, 1967

Florisphera profunda Okada \& Honjo 1973

Helicosphaera carteri (Wallich, 1877) Kamptner, 1954 [Coccosphaera]

Helicosphaera sellii (Bukry and Bramlette, 1969)

Oolithotus spp. Reinhardt in Cohen \& Reinhardt 1968

Pontosphaera spp. Lohmann, 1902

Pseudoemiliania lacunosa (Kamptner, 1963) Gartner, 1969

Rhabdosphaera clavigera Murray \& Blackman 1898

Syracosphaera spp. Lohmann 1902

Morphological groups

For the genus Reticulofenestra, we followed the morphometric subdivision established by Flores et al. (1995), considering 4 categories (VSR, SR, MR, LR). The term very small Reticulofenestra (VSR) is used for all specimens smaller than $3 \mu \mathrm{m}$, this group would be equivalent with Reticulofenestra minuta Roth, 1970. Small Reticulofenestra (SR) are all specimens between 3 and $5 \mu \mathrm{m}$. This group includes Reticulofenestra producta Kamptner, 1963 Reticulofenestra minutula Gartner, 1967 Haq and Berggren, 1978 and Reticulofenestra haqii Backman, 1978. The

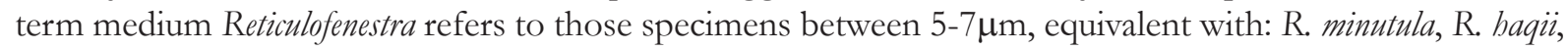
R. perplexa (Burns, 1975) Wise, $1983=$ D. antarcticus Haq. Large Reticulofenestra (LR) are larger than $7 \mu \mathrm{m}$ and are equivalent with Reticulofenestra psendoumbilicus (Gartner, 1967) Gartner, 1969.

For the genus Gephyrocapsa, specimens smaller than $3 \mu \mathrm{m}$ were grouped as small Gephyrocapsa (SG), as in Flores et al. (1999). For the late Pliocene this group includes Gephyrocapsa aperta Kamptner, 1963, Gephyrocapsa sinuosa Hay \& Baudry (1973) and the Gephyrocapsa protohuxleyi-morphotype (Samtleben, 1980). Specimens larger than $3 \mu \mathrm{m}$ will be named Medium Gephyrocapsa. This group consists of individuals of Gephyrocapsa margerelii Bréhéret. 



\section{Chapter 9: SYNTHesis (COMPARISON OF THE ATLANTIC AND THE PACIFIC RECORD)}

9.1. Paleoposition of the Subtropical Front

9.2. Glacial-interglacial variability

9.3. Plio-Pleistocene climate transition

9.4. The Eltanin impact

9.5. Small Noelaerbabdaceae 



\section{CHAPTER 9: SYNTHESIS (COMPARISON OF THE ATLANTIC AND THE PACIFIC RECORD).}

In the previous chapters we have discussed the calcareous nannofossil record of two different sediment cores: hole 1090 situated in the SAZ of the South Atlantic (later on called Atlantic site) and hole 1172 situated in the subtropical zone of the Tasman Sea (later on called Pacific site). In this last chapter, the results of both cores will be compared in order to make a general reconstruction of the paleoceanographic changes registered in the Southern Ocean during our study interval.

\subsection{Paleoposition of the STF}

The calcareous nannofossil assemblage found in both cores (Table 9.1) is interpreted as characteristic for the SAZ. This interpretation is based on (i) the absence, or really low, abundances of subtropical species, (ii) high abundances of $C$. pelagicus a typical cold-water species, (iii) abundances from $2-10 \%$ of Calcidiscus leptoporus, a species that frequently inhabits the zone south of the STF and (iv) the high abundances of small Noelaerbabdaceae which at present dominate the zone south of the STF.

\begin{tabular}{|c|c|c|c|c|c|c|c|}
\hline \multicolumn{8}{|c|}{ Dominant Taxa } \\
\hline \multicolumn{4}{|c|}{ ODP site 1172} & \multicolumn{4}{|c|}{ ODP site1090 } \\
\hline \multicolumn{5}{|c|}{ Relative abundance ( $\%$ of the total assemblage) } & \multicolumn{3}{|c|}{ Relative abundance ( $\%$ of the total assemblage) } \\
\hline Taxon & Minimum & Maximum & Average & Taxon & Minimum & Maximum & Average \\
\hline$\overline{V S R}+\mathrm{SG}$ & 13 & 92.2 & 67.5 & $\overline{V S R+S G}$ & 0.73 & 94.4 & 40.3 \\
\hline VSR & 13 & 77.1 & 40.8 & C. pelagicus & 2.1 & 98.4 & 38.1 \\
\hline SG & 0 & 70.7 & 26.7 & VSR & 0.49 & 75.1 & 32.3 \\
\hline C. pelagicus & 2 & 38 & 8.5 & SG & 0 & 73 & 8 \\
\hline C. leptoporus & 0.5 & 10.9 & 3.4 & C. leptoporus & 0 & 35.5 & 6.23 \\
\hline H. carteri & 0 & 0.9 & 0.2 & H. carteri & 0 & 0.42 & 0.04 \\
\hline Subtropical Taxa & 0 & 0.5 & 0.1 & Subtropical Taxa & & insignificant & \\
\hline \multicolumn{8}{|c|}{ Subordinate Taxa } \\
\hline \multicolumn{4}{|c|}{ ODP site 1172} & \multicolumn{4}{|c|}{ ODP site 1090} \\
\hline \multicolumn{4}{|c|}{ Relative abundance (\% excluding SG+VSR) } & \multicolumn{4}{|c|}{ Relative abundance (\% excluding SG+VSR) } \\
\hline Taxon & Minimum & Maximum & Average & Taxon & Minimum & Maximum & Average \\
\hline C. pelagicus & 5 & 69.5 & 26.1 & C. pelagicus & 8.7 & 99.1 & 60.04 \\
\hline C. leptoporus & 2.4 & 38.1 & 11.2 & C. leptoporus & 0 & 57.48 & 11.01 \\
\hline H. carteri & 0 & 2.5 & 0.5 & H. carteri & 0 & 1.35 & 0.094 \\
\hline Subtropical Taxa & 0 & 1 & 0.2 & Subtropical Taxa & & insignificant & \\
\hline
\end{tabular}

Table 9.1. Calcareous nannofossil assemblage at ODP site 1090 (South-Atlantic) and ODP site 1172 (South-Pacific).

This interpretation implies a northward position of the STF with respect to both study sites (Fig. 9.1). This is specially significant for the Pacific site where the STF currently is situated south of the study site. Our results suggest a northward (with respect to the present-day position) shift of the STF in the Pacific site and a similar position (with respect to the present-day position) in the Atlantic site (Fig. 9.1). Our results do not show evidences that nor the STF as the SAF moved over our study sites.

The position of the STF in the Pacific study area is highly influenced by the EAC. At present the southerly position of the STF is maintained by a strong EAC. Our results suggest that during our study interval the EAC and its warm-core eddies were, in contrast with the Pleistocene (Nürnberg and Groeneveld, 2006), 
LEG 177 (South-Atlantic)

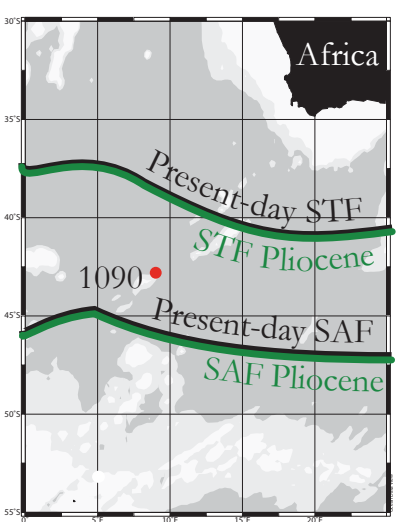

LEG 189 (South-Pacific)

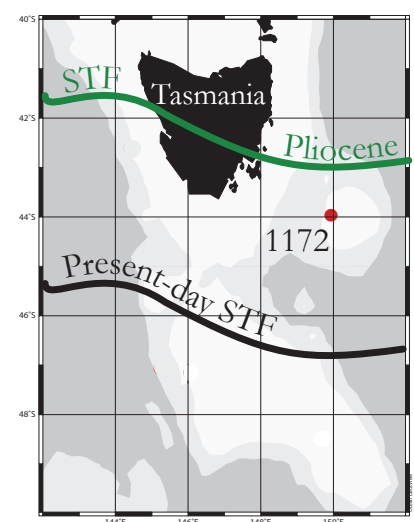

Fig. 9.1. Position of Subtropical and the Subantarctic Front (STF and SAF) during the studied interval (Pliocene) with respect to the study site. The inferred position of the fronts is indicated in green and the present-day position in black.

weaker or absent, allowing the STF to be positioned more north. This is not unlikely since the closure of the Indonesian Gateway, 5-3 Ma, largely affected the strength of the EAC. Modelling studies infer a distinct weakening of the warm EAC upon closing of the Indonesian Gateway (Godfrey, 1996; Hirst and Godfrey, 1993) which can explain the more northward position of the STF as indicated by the nannofossil assemblage.

Despite the fact that the position of the STF and the SAF front in the Atlantic site have a position similar to the present-day, some significant movements of this fronts have been infered. Before $2.82 \mathrm{Ma}$, the STF was situated close to site 1090, resulting in warmer SST's at our study site (Fig. 9.2a). After 2.72 Ma, a northward displacement of the fronts took place, leading to colder SST's. This displacement hace been linked to the changes of the ocean circulation upon the closure of the CAS (Fig. 9.2b). This period of colder SST's (2.72$2.0 \mathrm{Ma}$ ) is interrupted in two ocasions: between 2.44 and 2.34 Ma and between 2.14-2.0 Ma. During these periods, higher SST's have been inferred accompanied by a temporal southward displacement of the STF and SAF (Fig. 9.2c). The last important displacement of the fronts is registered around 2.0 Ma. At this time our nannofossil signal suggests warmer SST's and a a more southward position of the fronts, similar to the positions before $2.82 \mathrm{Ma}$ (Fig 9.2d).

(a) before $2.82 \mathrm{Ma}$

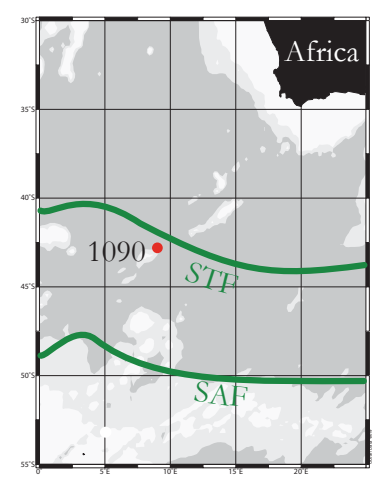

(b) $2.72-2.0 \mathrm{Ma}$

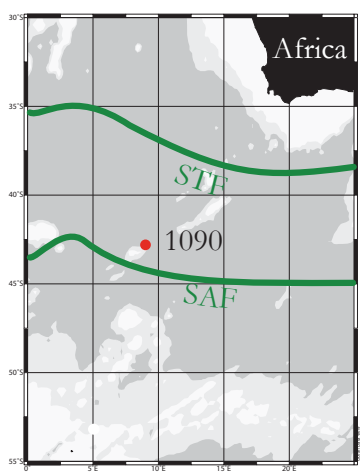

(c) $2.44-2.34 \mathrm{Ma}$ and $2.14-2.0 \mathrm{Ma}$

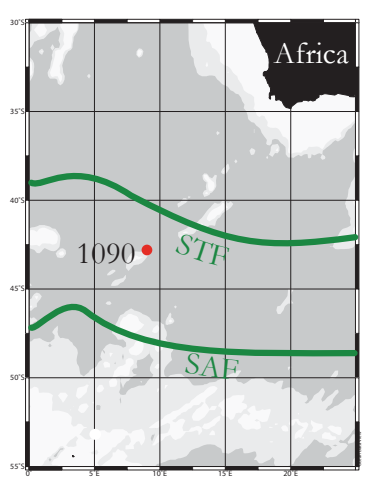

(d) after $2.0 \mathrm{Ma}$

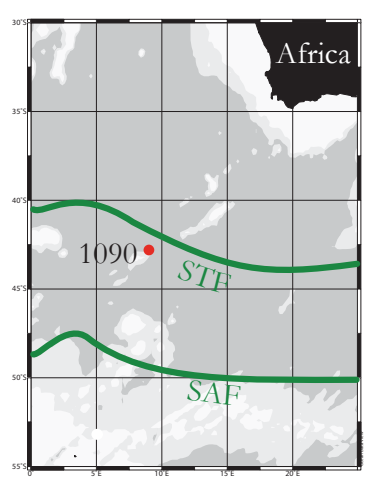

Fig. 9.2. Variations in the position of the Subantarctic (SAF) and the Subtropical Front (STF) at ODP site 1090.

In addition to the long-term variations of the oceanic fronts at both study sites, short-time variations of the species composition indicate moderate movement of the STF front across our section, in most cases related to G-IG cyclicity, which will be discussed below. 


\subsection{Glacial-Interglacial variability}

In both the Atlantic and the Pacific sector we observed significant fluctuations of the nannofossil assemblage in agreement with the G-IG variability. In the Atlantic site variations of the total NAR reveal higher nannofossil productivity during Terminations (Fig. 9.3). A Higher input of nutrients caused by

ODP site 1090
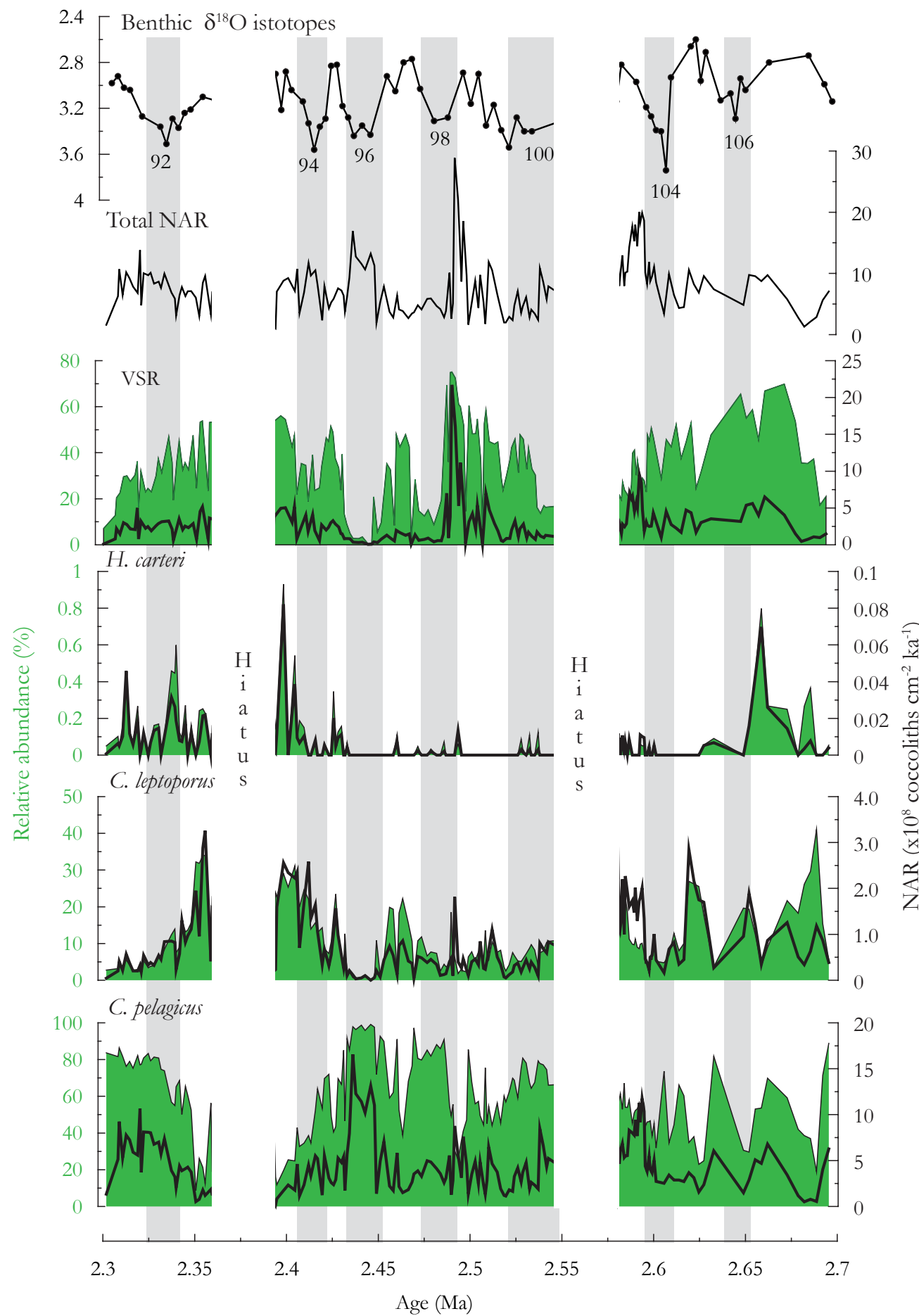

Fig. 9.3. Glacial-interglacial variability of the calcareous nannofossil taxa at ODP sites 1090. The relative abundance (solid green area) and the NAR values (black line) of the dominant taxa (C. pelagicus, C. leptoporus and $H$. carteri) are compared with the total NAR and the $\delta^{18} \mathrm{O}$ values to infer glacial interglacial variations. Glacials are indicated with grey bars. 
enhanced wind activity during glacial periods, as suggested by Latimer \& Filippelli (2001), explains the increasing NAR values during almost all glacial stages (except MIS 98) that culminate in higher productivity during terminations. This G-IG variation is relatively constant, with exception of MIS 96, 98 and 104 where remarkably larger fluctuations of the the total NAR have been registered. This is not surprising since it are these are the first "strong" glacial cycles registered after a sustaing warm period (The mid-Pliocene Warmth).

ODP site 1172
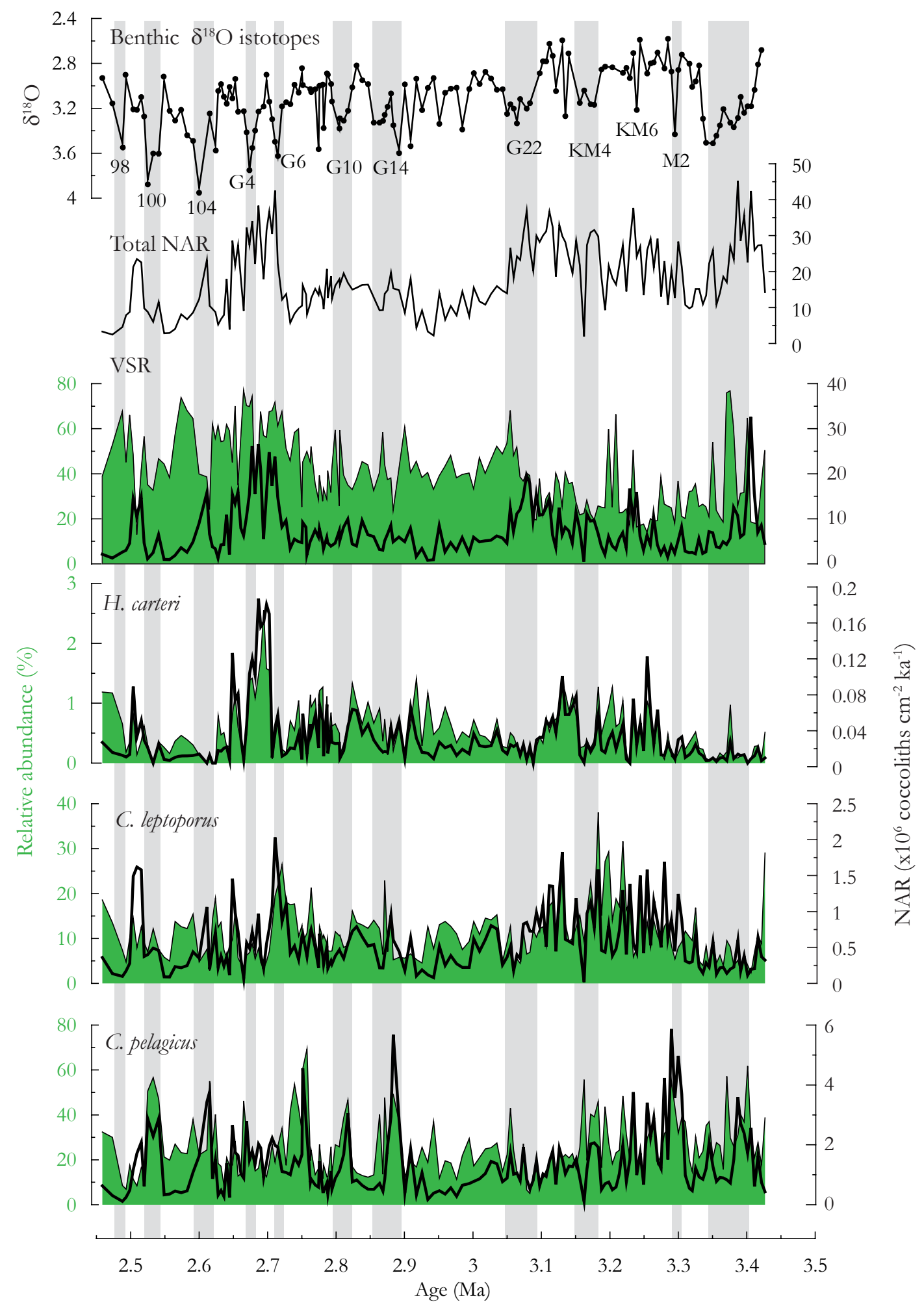
In the Pacific site we did not find a clear relationship between the total NAR variation and the G-IG cycles (Fig. 9.4). This may because the resolution of this record is lower and most of the isotopic stages are represented with one or two data points. Although is it remarkable that for the period between MIS 104 and MIS 98, stronger G-IG of the total NAR have been registered.

We can conclude that in both records we have registered an increased G-IG variability after MIS 104 which mostl likely is linked to a relatively strong cooling after the closure of the CAS and the intesification of the NHG.

In addition to the fluctuations of the total NAR, a small number of coccolithophore taxa show a clear G-IG pattern: C. pelagicus, C. leptoporus and H. carteri. C. pelagicus is more abundant during glacial periods whereas interglacial periods have higher abundances of C. leptoporus and H. carteri (Fig. 9.3 \& 9.4). A remarkable difference between the study sites is that in the Atlantic site we observed clear G-IG variations of VSR, with VSR being more abundant during IG (Fig. 9.3). This pattern is specially clear between MIS 100 and MIS 94, which is in agreement with a stonger G-IG cyclicity of the total NAR after the closure of the CAS and the intensification of the NHG. We suggest that, a temporal southward movement of the oceanic fronts took place during IG's. The higher proximity of ODP site 1090 to the STF would result in more intense mixing of the upper water column, allowing small placoliths to reach higher abundances. This pattern has not been observed in the Pacific site. The constant high abundances of VSR, both during G as IG may be an indication that the STF is situated close to ODP site 1172 during G and IG. In this study we have used H. carteri as an indicator for relatively warm SST's or IG. At ODP site 1090 this species is as good as absent between MIS 104 ans MIS 93. We suggest that a general cooling and stronger G-IG variability is the cause for the absence of this species during this period

\subsection{Plio-Pleistocene climate transition}

Superimposed on the G-IG variations, the nannofossil record reveals long-term trends which are of significant importance to decipher the Plio-Pleistocene climate transition. In both cores we have registered a trend towards cooler climate conditions in the Southern Ocean. In the Atlantic, cooling is inferred through a gradual increasing abundance of $C$. pelagicus which is a typical cold-water species (Fig. 9.5). The timing of this increased abundance coincides with the hiatus 1 and is thus situated between 2.82 and 2.72 Ma. We suggest that the definite closure of the CAS caused a general cooling of the South-Atlantic. Increased abundances of VSR, an upwelling indicator suggest that cooling probably went together with an intensification of the atmospheric circulation leading to more intense mixing of the upper water column. At ODP site 1172, an interval of relatively warm stable SST before $2.9 \mathrm{Ma}$ is followed by an interval characterized by short-time alternations between cold and warm SST. this cooling trend coincides with global cooling as infered by Lisiecki and Raymo (2005). In both cores we have registered a significant cooling upon the closure of the CAS, suggesting a general cooling of the Southern Ocean. This in agreement with the GCM models of Lunt et al. (2008).

Fig. 9.4. Glacial-interglacial variability of the calcareous nannofossil taxa at ODP site 1172. The relative abundance (solid green area) and the NAR values (black line) of the dominant taxa (C. pelagicus, C. leptoporus and H. carteri) are compared with the total NAR and the $\delta^{18} \mathrm{O}$ values to infer glacial interglacial variations. Glacials are indicated with grey bars. 


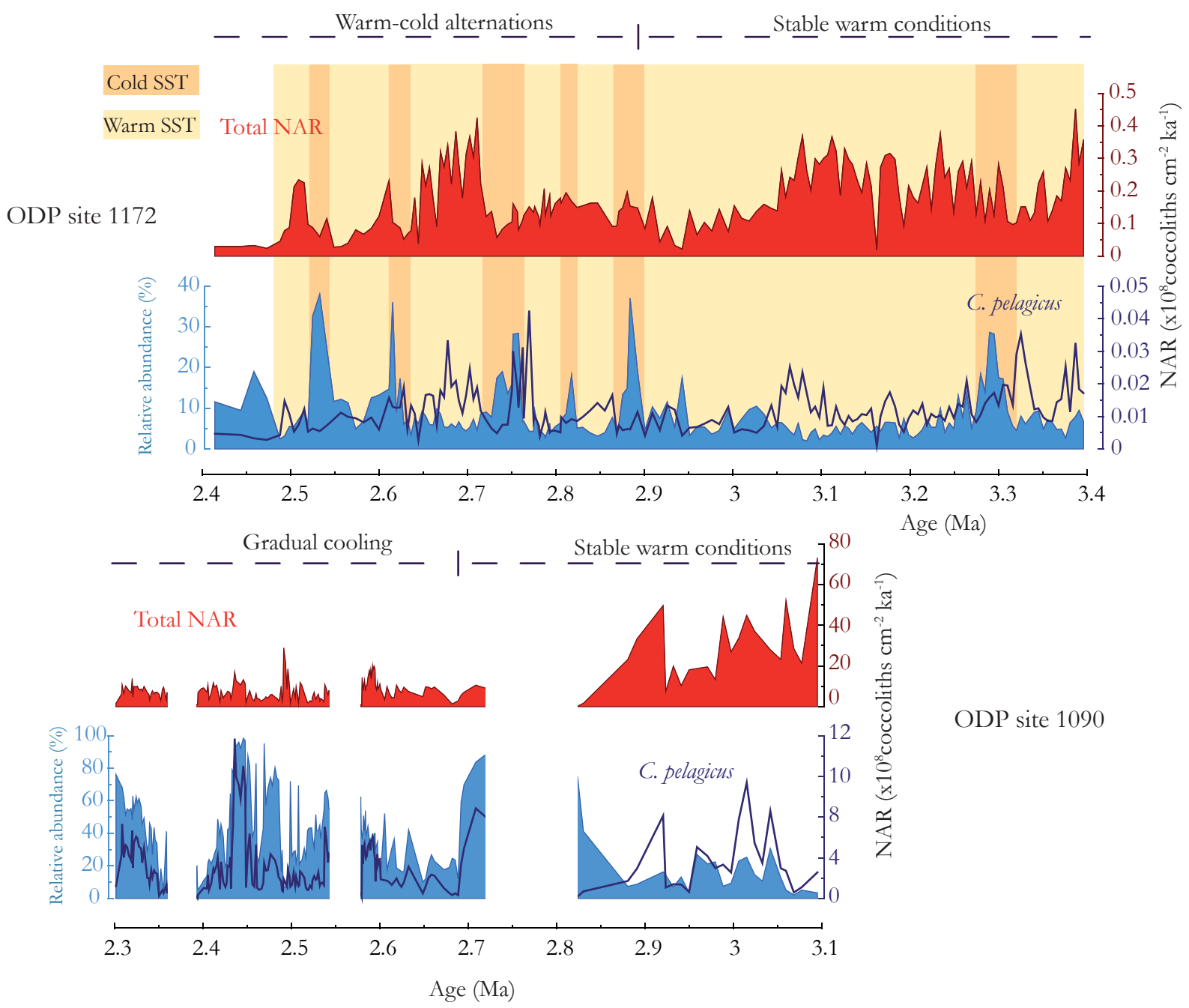

Fig. 9.5. Plio-Pleistocene climate transition. The relative abundance (solid blue area) and the NAR values (blue line) of C. pelagicus indicate a cooling trend in the Southern Ocean which goes together with changes in the total NAR (solid red area).

\subsection{The Eltanin impact}

One of the objectives during this work was to look for traces of the Eltanin impact, in our study record. The Eltanin impact is currently constrained to the age of $2.5 \mathrm{Ma}$ (Gersonde et al., 2005). At ODP site 1090 an anomaly is observed during MIS 99 where the accumulation rate of VSR reaches peak-values superior at $1.2 \times 10^{10}$ coccoliths $\mathrm{cm}^{-2} \mathrm{kyr}^{-1}$, while during all other interglacial periods values do not exceed $6.0 \times 10^{9}$ coccoliths $\mathrm{cm}^{2} \mathrm{kyr}^{-1}$ (Fig. 9.6). In other interglacial periods VSR dominate the assemblages, having values higher than 75\%, nevertheless, the NAR only reaches extreme values at the end of MIS 99. This increase ends abruptly at the beginning of MIS 98 and the duration of the high accumulation is 9 ka. The benthic isotopes do not indicate abnormal values for MIS 99. The large quantities of VSR have been interpreted as an indication of a period of higher nutrients concentrations in the surface waters, increased mixing of the water column or high environmental stress. The high productivity interval of VSR at ODP site 1090 thus could be a reflection of the consequences of the impact. The particles (soil, dust and sulfate aerosols) introduced in the atmosphere after the impact could have caused acid rain and a consequent biotic crisis, 
favoring opportunistic species with a high capacity for adaptation such as VSR. Nevertheless, there are no evidences that particles can stay in the atmosphere during such a prolonged time (several ka). Simulations of the environmental effects of impacts consider the consequences of an impact for the consequent years, not ka (Toon et al., 1997). Given the lack of knowledge of climatic effects caused by asteroid impacts, it is difficult to propose an alternative hypothesis including long term effects caused by the impact. Our nannofossil record suggests peak abundances of opportunistic species, however, the mechanism behind this is not clear.

Despite suggestions that the Eltanin impact might have caused alterations on a global scale (Chapman and Morrison, 1994), we didn't find any evidences related to the impact at site 1172. At ODP site 1172, a short maximum of the total NAR is registered during MIS 99 (Fig. 9.6). Nevertheless, this maximum is within the range of the fluctuations during the rest of the interval. The lack of evidences of the Eltanin impact in ODP site 1172 can be due to the relatively low resolution of the record of ODP site 1172 compared with site 1090 .
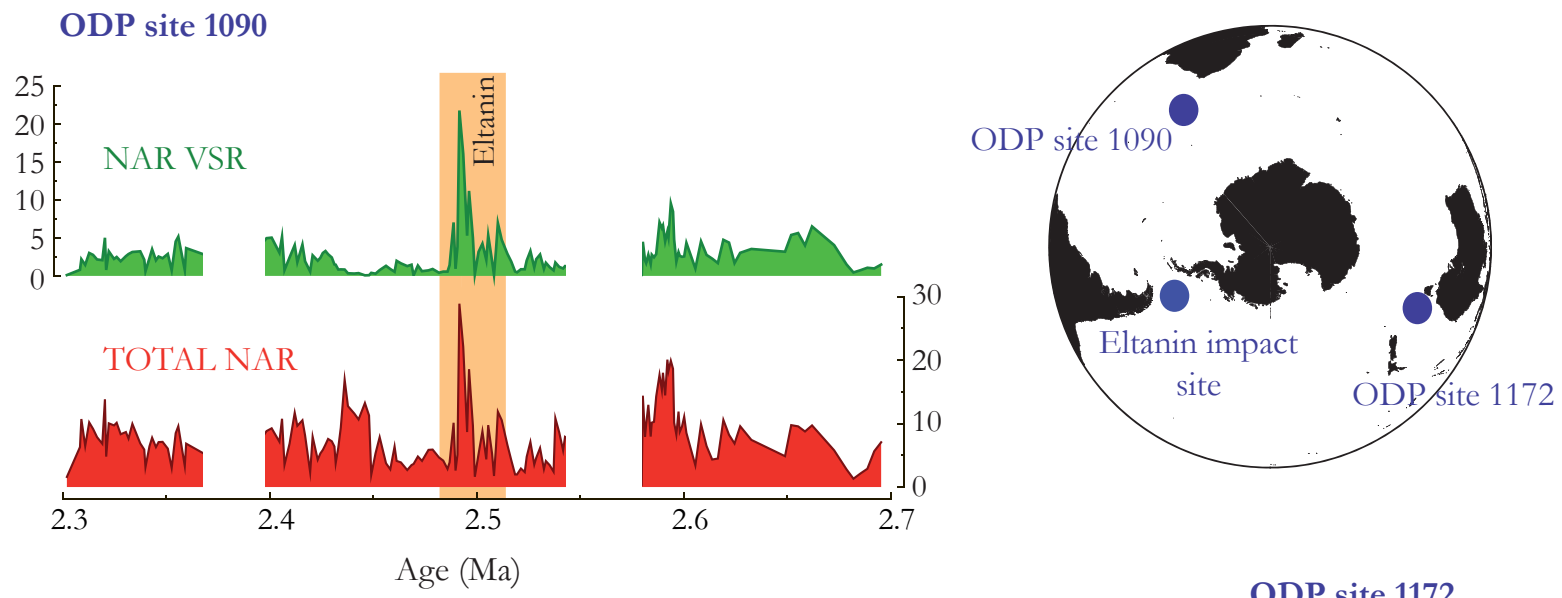

Age $(\mathrm{Ma})$

ODP site 1172

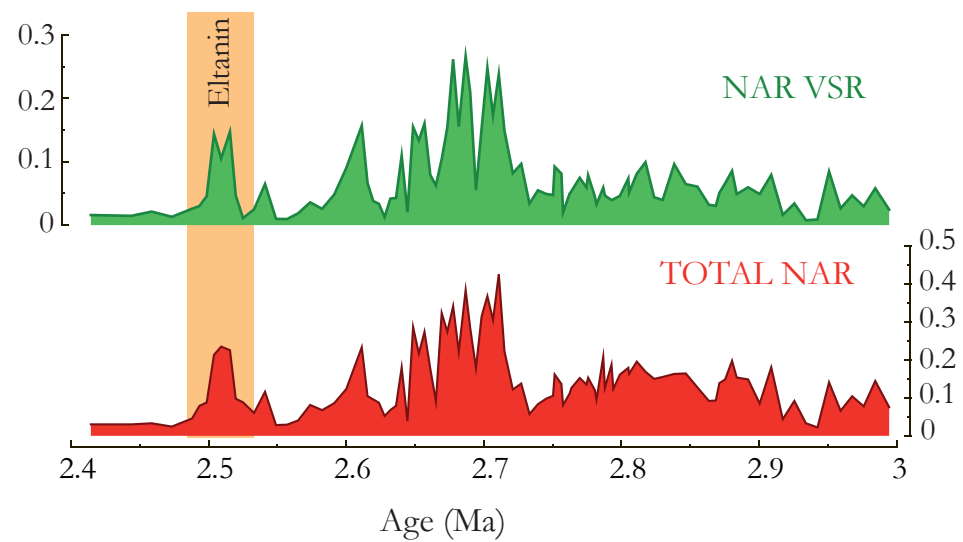

Fig. 9.6. The eltanin impact. Comparison of the Total NAR (red) and NAR values of VSR (green) reveal peak abundances during the interval of the Eltanin impact. The location of the study sites with respect to the impact site is indicated in the map.

\subsection{Small Noelaerhabdaceae}

In most studies, small Noelaerbabdaceae (also small placoliths $;<3 \mu \mathrm{m}$ ), including both SG and VSR, are grouped together to monitor past nutrient conditions (Aizawa et al., 2004; Takahashi and Okada, 2000; Takahashi and Okada, 2001) since in living assemblages these species correspond to eutrophic conditions 
(Young, 1994). Despite the fact that VSR and SG generally are grouped together, a significant trend within the small Noelaerbabdaceae group was observed in our record. In both cores we registered a rapid decline of SG leading to a temporal disappearance of this taxon: in the South Atlantic (ODP site 1090), the decline of SG coincides with the hiatus and is situated between 2.82 and $2.72 \mathrm{Ma}$, at ODP site 1172 (SouthPacific) this occurs between 2.77 and $2.73 \mathrm{Ma}$. A temporal disappearance of SG (TempDis SG) is not new, and was already described by Okada (2000) for the period between 2.9 and $2.5 \mathrm{Ma}$ and was proposed as a biostratigraphic marker in absence of discoaster species. In our record, TempDis SG coincides with important changes in the total NAR (Fig. 9.7), suggesting that TempDis SG might have been linked to environmental changes that also affected the total coccolithophore productivity.

In our record SG is replaced by VSR in the South Pacific and by VSR and C. pelagicus in the South Atlantic. VSR is known to respond to upwelling and general higher nutrient concentrations (Aubry, 1992; Flores et al., 1995). We suggest that the increasing nutrient concentration in the upper water column, most likely related to enhanced mixing of the upper water column might have favored VSR above SG.

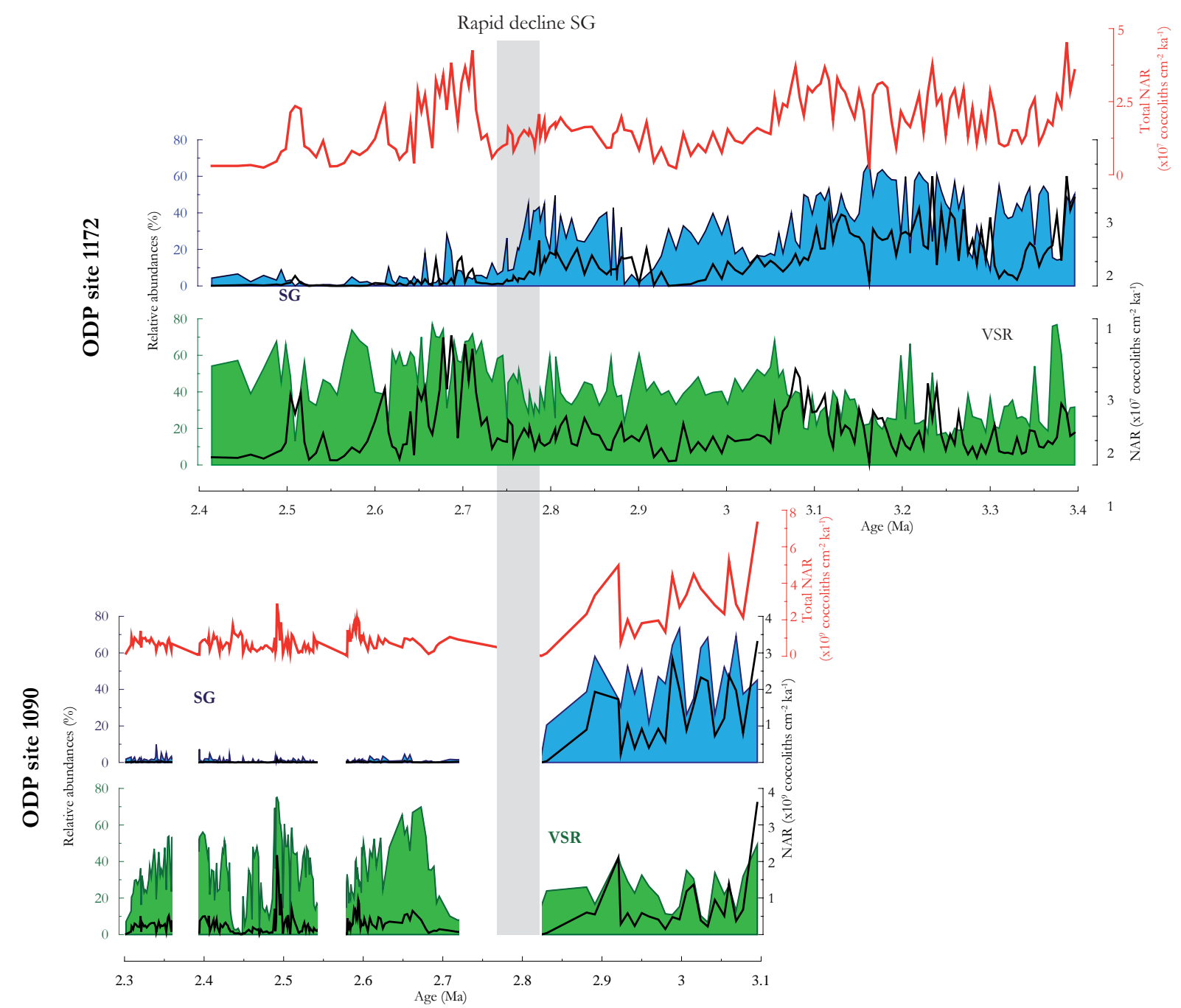

Fig. 9.5. Trends of small Noelaerhabdacea in the studied nannofossil records. Comparison of the relative abundances of VSR (green) and SG (blue) indicate a rapid decline of SG around 2.8 Ma. This event goes together with signifiant changes of the total NAR values (red). 
TempDis SG coincides with the interval of the definite closure of the CAS and the intensification of the NHG in both cores suggesting that both events might be related. This is not unlikely since a recent modeling study found an important link between the North Atlantic and the Southern Ocean (Lee et al., 2011). The simulations indicate that cooling in the North Atlantic caused a southward movement of the ITCZ which at his turn weakened the southern hemisphere's Hadley Circulation resulting in a strengthening of the southern hemisphere westerlies. This hypothesis could explain the increased abundance of VSR after the intensification of the NHG since stronger hemisphere westerlies are coupled with more intense mixing of the upper water column. Additionally, increased wind-driven upwelling during the late Pliocene was inferred through diatom records in the South Atlantic (ODP site 1084; Benguala upwelling System) (Marlow et al., 2000) and through the foraminifera record in the South Pacific (ODP site 1125; east of New Zealand) (Sabaa et al., 2004), supporting our hypothesis.

Evolution plays an important role in the distribution of the different coccolithophore species along geological time. Despite the high abundance of small Noelaerbabdaceae in the fossil record, we know relatively little about these species which makes it difficult to interpret the variations between different species within this group. The fact, however, that rapid declines in the SG record are associated with important changes in the nannofossil assemblage supports the idea that these events might be driven by environmental changes. In this context, Chapman and Chepstow-Lusty (1997) suggest that large-scale climatic changes at the end of the Pliocene altered the nutrient and temperature characteristics of the global ocean which might have led to disappearance of discoasters and the increase in the importance of other gephyrocapsid and VSR nannofossil floras, confirming our hypothesis. 

HAPTER 10: CONCLUSIONS/CONCLUSIONES 



\section{CHAPTER 10: CONCLUSIONS}

The analysis of the calcareous nannofossil record of ODP site 1090 (South-Atlantic) and ODP site 1172 (South-Pacific) led to the following conclusions.

- The calcareous nannoplankton assemblages of both records are associated with the Subantarctic Zone. This interpretation is based on:

(i) The absence, or very low abundances, of the subtropical taxa.

(ii) The relatively high abundances of $C$. pelagicus, a typical cold-water species.

(iii) Abundances between 2-10\% of C. leptoporus, a species that frequently inhabits the SAZ.

(iv) The high abundances of small Noelaerhabdacea, a species group that currently dominates the zone south of the STF.

The STF is situated north, and the SAF south, of the study sites during our study interval. Our results do not show evidences that the oceanic fronts moved over our study sites. We suggest that the northward position of the STF at ODP site 1172 was linked to a weaker EAC, allowing a more northward position of the STF and leading to an expansion of the transitional zone. At ODP site 1090 we registered significant movements of the STF and SAF, linked to important changes in the ocean circulation of the Subantarctic South-Atlantic. Before 2.82 Ma the STF was situated close to site 1090 as indicated by low abundances of $C$. pelagicus and high abundances of SG. A gradual increase of $C$. pelagicus between 2.72 and $2.0 \mathrm{Ma}$ suggests a significant cooling accompanied with a northward movement of the oceanic fronts. This displacement has been linked to final closure of the CAS around 2.74 Ma. At 2.43-2.34 Ma and 2.14-2.0 Ma we have inferred relatively warmer SST's (low C. pelagicus abundances and higher biodiversity) coupled with a temporal southward movement of the fronts. After 2.0 Ma the nannofossil assemblage is similar to the interval before $2.82 \mathrm{Ma}$, suggesting a similar position of the STF and SAF.

- The calcareous nannofossils assemblages revealed a G-IG pattern. Glacial periods are characterized with relatively high abundances of $C$. pelagicus whereas interglacials have higher abundances of $C$. leptoporus and H. carteri. In the South-Atlantic, the relative abundances of VSR show a G-IG pattern with VSR being more abundant during IG. This pattern is not observed in the South-Pacific. In both records we have seen an increased G-IG variability after MIS104, which most likely is related with a significant cooling of the Southern Ocean after the closure of the CAS and the intensification of the NHG.

- Within the small Noelaerbabdaceae group, we observed a rapid decline of SG leading to a temporal disappearance of this taxon in both cores: in the South Atlantic, the decline of SG coincides with the hiatus and is situated between 2.82 and $2.72 \mathrm{Ma}$, in the South-Pacific this occurs between 2.77 and 2.73 Ma. In the South Pacific SG is replaced by VSR and in the South Atlantic by VSR and C. pelagicus. We suggest that an increasing nutrient concentration in the upper water column (most likely related to enhanced mixing of the upper water column) and colder SST forced the temporal disappearance of SG. The temporal disappearance SG coincides with the interval of the definite closure of the CAS 
and the intensification of the NHG suggesting that cooling in the North Atlantic caused a southward movement of the ITCZ which at his turn weakened the southern hemisphere's Hadley Circulation resulting in a strengthening of the southern hemisphere westerlies. This hypothesis could explain the increased abundance of VSR after the intensification of the NHG since stronger hemisphere westerlies are coupled with more intense mixing of the upper water column.

- Calculation of the different carbonate dissolution indexes revealed that species specific dissolution indexes based on the fragmentation of $C$. leptoporus and $C$. pelagicus are the best proxies to assess past carbonate dissolution. The fluctuations of DP and DL revealed higher fragmentation between 2.72 and 2.2 Ma. High fragmentation before and after hiatus 3 and 4 indicates that these hiatus may be the result of dissolution events. Besides, DL and DP showed a trend towards a better preservation after 2.2 Ma. A better preservation might be related to an intensification of the NCW circulation during this period.

- At ODP site 1090 a anamolous high abundance is recorded during MIS 99. The timing of this event, around 2.49 Ma, coincides with the interval of the Eltanin impact. We suggest that the injection of a large amount of dust or particles in the atmopshere after the impact may have led to acid rain, favoring opportunistic species such as VSR. At ODP site 1172 we didn't find any evidences which could be related to the Eltanin impact. 


\section{CAPÍTULO 10: CONCLUSIONES}

El análisis de los registros de nanofósiles calcáreos del testigo ODP 1090 (Atlántico Sur) y testigo ODP 1172 (Pacífico Sur) han resultado en las siguientes conclusiones:

- Las asociaciones de nanofósiles calcáreos de ambos registros están asociadas con la zona subantárctica. Esta interpretación se basa en:

(i) La ausencia, o muy baja abundancia, de los taxones subtropicales.

(ii) Las abundancias relativamente altas de C. pelagicus, una especie típica de aguas frías.

(iii) Abundancias entre 2-10 \% de C. leptoporus, una especie que se encuentra frecuentemente en la zona subantárctica.

(iv) Las altas abundancias de pequeños Noelaerhabdacea, un grupo de especies que actualmente domina la zona situada al sur del Frente Subtropical.

Durante el intervalo estudiado el Frente Subtropical y el Frente Subantárctico estaban situados al norte y al sur del área de estudio respectivamente. Los resultados no muestran evidencias de que los frentes oceánicos se hayan movido por encima de los testigos. Sugerimos que la posición hacia el norte del Frente Subtropical en la zona del testigo ODP 1172 está vinculada con un debilitamiento de la EAC (Corriente Este de Australia), permitiendo una posición más hacia el norte del Frente Subtropical. Se han registrado movimientos significantes del Frente Subtropical y Subantárctico en la zona del testigo ODP 1090, relacionados con cambios importantes de la circulación oceánica de la zona subantárctica del Atlántico Sur. Antes de $2.82 \mathrm{Ma}$, el Frente Subtropical estaba situado cerca del testigo 1090 como indican la baja abundancia de C. pelagicus y la elevada abundancia relativa de SG. El incremento gradual de $C$. pelagicus entre 2.72 y 2.0 Ma refleja unas condiciones más frías en la columna de agua acompañadas con un desplazamiento hacia el norte de los frentes oceánicos. Dicho desplazamiento ha sido relacionado con el cierre definitivo de istmo de Panamá, alrededor de 2.74 Ma. Durante los intervalos 2.43-2.34 Ma y 2.14-2.0 Ma hemos inferido temperaturas superficiales relativamente más altas (bajas abundancias de C. pelagicus y una biodiversidad más alta) asociadas a un desplazamiento temporal hacia el sur de los frentes. Después de 2.0 Ma la asociación de nanofósiles es parecida al intervalo anterior a $2.82 \mathrm{Ma}$, lo que indica una posición del Frente Subtropical y Subantártico similar.

- Las asociaciones de nanofósiles calcáreos muestran un patrón glacial-interglacial (G-IG). Los periodos glaciales están caracterizados por abundancias relativas altas de C. pelagicus mientras que los interglaciales presentan abundancias más altas de C. leptoporus y H. carteri. En el Atlántico Sur, las abundancias relativas de los pequeños Reticulofenestra (VSR) muestran un patrón G-IG siendo más abundantes durante los IG. Este patrón no se ha encontrado en el testigo 1172. En ambos registros se ha observado un incremento en la variabilidad G-IG después de MIS 104, que probablemente está relacionado con un enfriamiento significante del Océano Sur tras el cierre del istmo de Panamá y la intensificación de la glaciación en el Hemisferio Norte.

- Dentro del grupo de los pequeños Noelaerbabdaceae, hemos observado un descenso rápido de pequeños Gephyrocapsa (SG) hasta alcanzar la desaparición temporal de este taxón en ambos testigos: en el Atlántico Sur, el descenso de SG coincide con un hiato y está situado entre 2.82 y 2.72 Ma, en 
el Pacífico Sur, esto ocurre entre 2.77 y 2.73 Ma. En el Pacífico Sur SG es reemplazado por VSR, mientras que en el Atlántico Sur es sustituida por VSR y C.pelagicus. Sugerimos que un incremento de la concentración de nutrientes en la parte superficial de la columna de agua (probablemente relacionado con una intensificación de la mezcla de las aguas superficiales) y temperaturas superficiales más bajas provocaron la desaparición temporal de SG. La desaparición temporal de SG coincide con el intervalo del cierre definitivo del istmo de Panamá y la intensificación de la glaciación del Hemisferio Norte. Un enfriamiento en el Atlántico Norte pudo haber causado un desplazamiento hacia el sur de la zona de convergencia intertropical que a su vez pudo desencadenar un debilitamiento en la circulación de Hadley en el Hemisferio Sur resultando en una intensificación de los vientos de componente oeste. Esta hipótesis podría explicar el ascenso de la abundancia de VSR después de la intensificación de la glaciación del Hemisferio Norte ya que la intensificación de los vientos de componente oeste está asociada con una mezcla más intensa de las aguas superficiales.

- De todos los diferentes índices de disolución de carbonato calculados los índices basados en la fragmentación de una única especie (C. leptoporus; DL y C. pelagicus; DP) se presentan como los mejores indicadores de disolución. Las fluctuaciones de DP y DL indican una fragmentación más elevada entre 2.72 y $2.2 \mathrm{Ma}$. Durante este intervalo, la alta fragmentación antes y después hiato 3 y 4 indica que estos hiatos podrían ser consecuencia de un evento de disolución. Asimismo, DL y DP muestran una mejor preservación después de 2.2 Ma que podría estar relacionada con una mayor producción de la masa de agua del norte.

- En el testigo ODP 1090 se ha registrado una abundancia anómalamente alta de VSR durante el estadio isotópico 99. La ocurrencia de esta anomalía coincide con el intervalo del impacto del Eltanin. Sugerimos que la proyección de una alta cantidad de polvo o partículas a la atmosfera después del impacto pudo haber provocado lluvia ácida, favoreciendo especies oportunistas como VSR. En cambio, en el testigo ODP 1172 no hemos encontrado evidencias relacionadas con el impacto. 
References 

Aizawa, C., Oba, T., Okada, H., 2004. Late Quaternary paleoceanography deduced from coccolith assemblages in a piston core recovered off the central Japan coast. Marine Micropaleontology, 52(1-4): 277-297.

Allanson, B.R., Hart, R.C., Lutjeharms, J.R.E., 1981. Observations on the nutrients, chlorophyll and primary production of the Southern Ocean south of Africa. South African Journal of Antarctic Research, 10/11(3-14).

Ansorge, I.J., Speich, S., Lutjeharms, J.R.E., Göni, G.J., Rautenbach, W., Froneman, P.W., Rouault, M., Garzoli, S., 2005. Monitoring the oceanic flow between Africa and Antarctica: Report of the first Goodhope cruise. South African Journal of Science, 101: 29-34.

Aubry, M.P., 1992. Late Paleogene calcareous nannoplankton evolution: A tale of climate deterioration. In: D.R. Prothero and W.A. Berggren (Editors), Eocene-Oligocene Climatic and Biotic Evolution. Princeton University Press, pp. 272-309.

Aubry, M.P., 2009. A sea of Lilliputians. Palaeogeography, Palaeoclimatology, Palaeoecology, 284(1-2): 88113.

Backman, J., Shackleton, N.J., 1983. Quantitative biochronology of Pliocene and early Pleistocene calcareous nannofossils from the Atlantic, Indian and Pacific oceans. Marine Micropaleontology, 8(2): 141170.

Bard, E., Rickaby, R.E.M., 2009. Migration of the subtropical front as a modulator of glacial climate. Nature, 460(7253): 380-383.

Barreiro, M., Philander, G., Pacanowski, R., Federov, A., 2006. Simulations of warm tropical conditions wih application to middle Pliocene atmospheres. Climate Dynamics, 26: 349-365.

Bartoli, G., Sarnthein, M., Weinelt, M., Erlenkeuser, H., Garbe-Schönberg, D., Lea, D.W., 2005. Final closure of Panama and the onset of Northern Hemisphere Glaciation. Earth and Planetary Science Letters, 237(1-2): 33-44.

Baumann, K.H., 1995. Morphometry of Quaternary Coccolithus pelagicus coccoliths from northern North Atlantic and its palaeoceanographical significance. In: J.A. Flores, F.J. Sierro and G. Glacon (Editors), 5th INA Conference in Salamanca Proceedings, pp. 11-21.

Baumann, K.H., Andruleit, H., Boeckel, B., Geisen, M., Kinkel, H., 2005. The significance of extant coccolithophores as indicators of ocean water masses, surface water temperature, and paleoproductivity: a review. Paläontologische Zeitschrift, Vol. 79(1): 93-112.

Baumann, K.H., Cepek, M., Kinkel, H., 1999. Coccolithophores as Indicators of Ocean Water Masses, Surface-Water Temperature, and Paleoproductivity - Examples fromm the South Atlantic. In: G. Fischer and G. Wefer (Editors), Use of Proxies in Paleoceanography: Examples from the South Atlantic. Springer-Verlag Berlin Heidelberg, pp. 117-144.

Baumann, K.-H.Freitag, T., 2004. Pleistocene fluctuations in the northern Benguela Current system as revealed by coccolith assemblages. Marine Micropaleontology, 52(1-4): 195-215.

Beaufort, L., Aubry, M.P., 1990. Fluctuations in the composition of late Miocene calcareous nannofossil assemblages as a response to orbital forcing. Paleoceanography, 5(6): 845-865.

Belkin, I.M., Gordon, A.L., 1996. Southern Ocean fronts from the Greenwich meridian to Tasmania. Journal of Geophysical Research, 101: 3675-3696.

Berger, W.H., 1970. Planktonic foraminifera: selective solution and lysocline. Marine Geology, 8: 111-138.

Bickert, T., Wefer, G., 1996. Late Quaternary deep-water circulation in the South Atlantic: reconstruction from carbonate dissolution and benthic stable isotopes. In: G. Wefer, W.H. Berger, G. Siedler and D. Webb (Editors), The South Atlantic: present and past circulation. Springer.Verlag, Berlin, pp. 599-620.

Billard, C., 1994. Life Cycles. In: J.C. Green and B.S.C. Leadbeater (Editors), The Hapthophyte Algae. Systematic Association pp. 167-186.

Billups, K., Ravelo, A.C., Zachos, J.C., 1997. Early Pliocene deep-water circulation: stable isotope evidence for enhanced northern component deep water. Proc. ODP, Sci. Results, 154: College station, TX (Ocean Drilling Program), 73-82.

Billups, K., Ravelo, A.C., Zachos, J.C., Norris, R.D., 1999. Link between oceanic heat transport, thermohaline circulation, and the Intertropical Convergence Zone in the early Pliocene Atlantic. Geology, 27(4): 319-322. 
Blaj, T., Backman, J., Raffi, I., 2009. Late Eocene to Oligocene preservation history and biochronology of calcareous nannofossils form paleo-equatorial Pacific Ocean Sediments. Riv. Ital. Paleontol. Stratigr., 115(1): 67-85.

Boeckel, B., Baumann, K.H., 2004. Distribution of coccoliths in surface sediments of the south-eastern South Atlantic Ocean: ecology, preservation and carbonate contribution. Marine Micropaleontology, 51(3-4): 301-320.

Boeckel, B., Baumann, K.H., Henrich, R., Kinkel, H., 2006. Coccolith distribution patterns in South Atlantic and Southern Ocean surface sediments in relation to environmental gradients. Deep Sea Research Part I: Oceanographic Research Papers, 53(6): 1073-1099.

Bollmann, J., 1997. Morphology and biogeography of Gephyrocapsa coccoliths in Holocene sediments. Marine Micropaleontology, 29(3-4): 319-350.

Bolton, C.T., Gibbs, S.J., Wilson, P.A., 2010a. Evolution of nutricline dynamics in the equatorial Pacific during the late Pliocene. Paleoceanography, 25(1): PA1207.

Bolton, C.T., Lawrence, K.T., Gibbs, S.J., Wilson, P.A., Cleaveland, L.C., Herbert, T.D., 2010b. Glacialinterglacial productivity changes recorded by alkenones and microfossils in late Pliocene eastern equatorial Pacific and Atlantic upwelling zones. Earth and Planetary Science Letters, 295(3-4): 401411.

Bonham, S.G., Haywood, A.M., Lunt, D.J., Collins, M., Salzmann, U., 2009. El Niño-Southern Oscillation, Pliocene climate and equifinality. Phil. Trans. R. Soc. A, 367: 127-156.

Brand, L.E., 1994. Physiological ecology of marine coccolithophores. In: A. Winter and W.G. Siesser (Editors), Coccolithophores. Cambridge Univ. Press, pp. 39-49.

Broecker, W.S., 1974. Chemical Oceanography, New York.

Bukry, D., 1991. Paleoecological transect of western Pacific Ocean Late Pliocene coccolith flora: Part I. Tropical Ontong-Java Plateau at ODP 806B. U.S. Geological Survey, Open-File Report, 91(552): $1-35$.

Burns, D.A., 1973. The latitudinal distribution and significance of calcareous nannofossils in the bottom

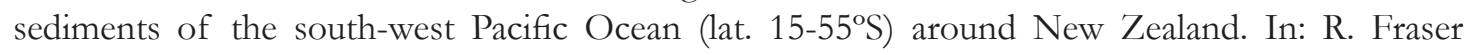
(Editor), New Zealand National Commission for UNESCO, Wellington, pp. 221-228.

Cachão, M., Moita, M.T., 2000. Coccolithus pelagicus, a productivity proxy related to moderate fronts off Western Iberia. Marine Micropaleontology, 39(1-4): 131-155.

Cane, M.A., 1998. CLIMATE CHANGE: A Role for the Tropical Pacific. Science, 282(5386): 59-61.

Cane, M.A., Molnar, P., 2001. Closing of the Indonesian seaway as a precursor to east African aridification around 3-4 million years ago. Nature, 411: 157-162.

Castradori, D., 1993. Calcareous nannofossil biostratigraphy and biochronology in eastern Mediterranean deep-sea cores. Riv. Ital. Paleontol. Stratigr, 99: 107-126.

Coates, A.G., Collins, L.S., Aubry, M.P., Berggren, W.A., 2004. The geology of the Darien, Panama, and the late Miocene-Pliocene collision of the Panama arc with northwestern South America. Geological Society of America Bulletin, 116: 1327-1344.

Collins, L.S., Coates, A.G., Berggren, W.A., Aubry, M.P., Zhang, J., 1996. The late Miocene Panama isthmian strait. Geology, 24: 687-690.

Coplen, T.B., 1996. New guidelines for reporting stable hydrogen, carbon, and oxygen isotope-ratio data. Geochimica et Cosmochimica Acta, 60(17): 3359-3360.

Cortese, G., Gersonde, R., 2008. Plio/Pleistocene changes in the main biogenic silica carrier in the Southern Ocean, Atlantic Sector. Marine Geology, 252(3-4): 100-110.

Crowley, T.J., 1996. Pliocene climates: The nature of the problem. Marine Micropaleontology, 27: 3-12.

Chapman, C.R., Morrison, D., 1994. Impacts on the Earth by asteroids and comets: assessing the hazard. Nature, 367(6458): 33-40.

Chapman, M.R., Chepstow-Lusty, A.J., 1997. Late Pliocene climatic change and the global extinction of the discoasters: an independent assessment using oxygen isotope records. Palaeogeography, Palaeoclimatology, Palaeoecology, 134(1-4): 109-125.

Charlton, T.R., 1986. A plate tectonic model of the eastern Indonesia collision zone. Nature, 319(6052): 394-396. 
DeConto, R.M., Pollard, D., 2003. Rapid Cenozoic glaciation of Antarctica induced by declining atmospheric CO2. Nature, 421(6920): 245-249.

DeMets, C., Gordon, R.G., Argus, D.F., Stein, S., 1994. Effect of recent revisions to the geomagnetic reversal time scale on estimates of current plate motions. Geophys. Res. Lett., 21(20): 2191-2194.

Diekmann, B., Fälker, M., Kuhn, G., 2003. Environmental history of the south-eastern South Atlantic since the Middle Miocene: evidence from the sedimentological records of ODP Sites 1088 and 1092. Sedimentology, 50: 511-529.

Diekmann, B., Kuhn, G., 2002. Sedimentary record of the mid-Pleistocene climate transition in the southeastern South Atlantic (ODP Site 1090). Palaeogeography, Palaeoclimatology, Palaeoecology, 182(3-4): 241-258.

Dittert, N., Baumann, K.H., Bickert, T., Henrich, R., Kinkel, H., Meggers, H., 1999. Carbonate dissolution in the Deep-Sea: Methods, Quantification and Paleoceanographic Application. In: G. Fischer and G. Wefer (Editors), Proxies in paleoceanography: Examples from the South Atlantic. Springer, Berlin, pp. 255-284.

Dowsett, H., Barron, J., Poore, R., 1996. Middle Pliocene sea surface temperatures: a global reconstruction. Marine Micropaleontology, 27(1-4): 13-25.

Dowsett, H., Willard, D., 1996. Southeast Atlantic marine and terrestrial response to middle Pliocene climate change. Marine Micropaleontology, 27(1-4): 181-193.

Dowsett, H.J., 2007. The PRISM Palaeoclimate Reconstruction and Pliocene Sea-Surface Temperature. In: M. Williams, A.M. Haywood, G. J. and D. Schmidt (Editors), Deep-time perspectives on climate change: marrying the signal from computer models and biological proxies. The Micropalaeontological Society Special Publications The Geological Society of London.

Dowsett, H.J., Barron, J.A., Poore, R.Z., Thompson, R.S., Cronin, T.M., Ishman, S.E., Willard, D.A., 1999. Middle Pliocene paleoenvironmental reconstruction: PRISM2. U.S. Geological Survey Open-File Report, 99-535: 13 pp.

Dowsett, H.J., Cronin, T.M., Poore, R.Z., Thompson, R.S., Watley, R.C., Wood, A.M., 1992. Micropaleontological evidence for increased meridional heat transport in the North Atlantic during the Pliocene. Science, 258: 1133-1135.

Dowsett, H.J., Chandler, M.A., Robinson, M.M., 2009. Surface temperatures of the Mid-Pliocene North Atlantic Ocean: implications for future climate. Philosophical Transactions of the Royal Society A: Mathematical, Physical and Engineering Sciences, 367(1886): 69-84.

Dowsett, H.J.Robinson, M.M., 2009. Mid-Pliocene equatorial Pacific sea surface temperaturesreconstruction: a multi-proxy perspective. Philosophical Transactions of the Royal Society A: Mathematical, Physical and Engineering Sciences, 367: 109-125.

Dowsett, H.J., Robinson, M.M., Haywood, A.M., Salzmann, U., Hill, D.J., Sohl, L., Chandler, M., Williams, M., Foley, K., Stoll, D.K., 2010. The PRISM3D paleoenvironmental reconstruction. Stratigraphy, 7(2-3): 123-129.

Dupont, L.M., 2006. Late Pliocene vegetation and climate in Namibia (southern Africa) derived from palynology of ODP Site 1082. Geochem. Geophys. Geosyst., 7(5): Q05007.

Dupont, L.M., Donner, B., Vidal, L., Pérez, E.M., Wefer, G., 2005. Linking desert evolution and coastal upwelling: Pliocene climate change in Namibia. Geology, 33(6): 461-464.

Duque-Caro, H., 1990. Neogene stratigraphy, paleoceanography and paleobiogeography in northwest South America and the evolution of the Panama seaway. Palaeogeography, Palaeoclimatology, Palaeoecology, 77(3-4): 203-234.

Dwyer, G.S., Chandler, M.A., 2009. Mid-Pliocene sea level and continental ice volume based on coupled benthic $\mathrm{Mg} / \mathrm{Ca}$ paleotemperatures and oxygen isotopes. Philosophical Transactions of the Royal Society A, 367: 157-168.

Esper, O., Versteegh, G.J.M., Zonneveld, K.A.F., Willems, H., 2004. A palynological reconstruction of the Agulhas Retroflection (South Atlantic Ocean) during the Late Quaternary. Global and Planetary Change, 41(1): 31-62.

Etourneau, J., Martinez, P., Blanz, T., Schneider, R., 2009. Pliocene-Pleistocene variability of upwelling activity, productivity, and nutrient cycling in the Benguela region. Geology, 37(10): 871-874. 
Etourneau, J., Schneider, R., Blanz, T., Martinez, P., 2010. Intensification of the Walker and Hadley atmospheric circulations during the Pliocene-Pleistocene climate transition. Earth and Planetary Science Letters, 297(1-2): 103-110

Exon, N.F., Kennett, J.P., Malone, M.J.E., 2001. Proc. ODP, Init. Repts, 189: College Station, TX (Ocean Drilling Program).

Exon, N.F., Kennett, J.P., Malone, M.J.E., 2004. Proc. ODP, Sci. Results, 189: College Station, TX (Ocean Drilling Program).

Eynaud, F., Giraudeau, J., Pichon, J.J., Pudsey, C.J., 1999. Sea-surface distribution of coccolithophores, diatoms, silicoflagellates and dinoflagellates in the South Atlantic Ocean during the late austral summer 1995. Deep Sea Research Part I: Oceanographic Research Papers, 46(3): 451-482.

Farrell, J.W., Raffi, I., Janecek, T., Murray, D.W., Levitan, M., Dadey, K.A., Emeis, K.C., Lyle, M., Flores, J.A., Hovan, S., 1995. Late Neogene Sedimentation patterns in the eastern equatorial Pacific Ocean. In: N.G. Pisias, L.A. Mayer, T.R. Janecek, A. Palmer-Julson and T.H. van Andel (Editors), Proc. ODP, Sci. Results:138. College Station, TX (Ocean Drilling Program), 717-756.

Felton, E.A., Crook, K.A.W., 2003. Evaluating the impacts of huge waves on rocky shorelines: an essay review of the book 'Tsunami - The Underrated Hazard'. Marine Geology, 197(1-4): 1-12.

Fenner, J., Di Stefano, A., 2004. Late Quaternary oceanic fronts along Chatham Rise indicated by phytoplankton assemblages, and refined calcareous nannofossil stratigraphy for the mid-latitude SW Pacific. Marine Geology, 205(1-4): 59-86.

Fenner, J.M., 1991. Late Pliocene-Quaternary quantitative diatom stratigraphy in the Atlantic Sector of the Southern Ocean. In: P.F. Ciesielski and Y. Kristoffersen (Editors), Proc. ODP, Sci. results 114: College station, TX (Ocean Drilling Program), 97-121.

Fincham, M.J., Winter, A., 1989. Paleoceanographic interpretations of coccoliths and oxygen-isotopes from the sediment surface of the southwest Indian Ocean. Marine Micropaleontology, 13(4): 325-351.

Findlay, C.S., Flores, J.A., 2000. Subtropical Front fluctuations south of Australia (4509'S, $\left.146^{\circ} 17^{\prime} \mathrm{E}\right)$ for the last $130 \mathrm{ka}$ years based on calcareous nannoplankton. Marine Micropaleontology, 40(4): 403-416.

Findlay, C.S., Giraudeau, J., 2000. Extant calcareous nannoplankton in the Australian Sector of the Southern Ocean (austral summers 1994 and 1995). Marine Micropaleontology, 40(4): 417-439.

Findlay, C.S., Giraudeau, J., 2002. Movement of oceanic fronts south of Australia during the last 10 ka: interpretation of calcareous nannoplankton in surface sediments from the Southern Ocean. Marine Micropaleontology, 46(3-4): 431-444.

Flores, J.A., Marino, M., Sierro, F.J., Hodell, D.A., Charles, C.D., 2003. Calcareous plankton dissolution pattern and coccolithophore assemblages during the last $600 \mathrm{kyr}$ at ODP Site 1089 (Cape Basin, South Atlantic): paleoceanographic implications. Palaeogeography, Palaeoclimatology, Palaeoecology, 196(3-4): 409-426.

Flores, J.A., Sierro, F.J., 2007. Pronounced mid-Pleistocene southward shift of the Polar Front in the Atlantic sector of the Southern Ocean. Deep Sea Research Part II: Topical Studies in Oceanography, 54(2122): 2432-2442.

Flores, J.A., Sierro, F.J., Raffi, I., 1995. Evolution of the calcareous nannofossil assemblage as a response to the Paleoceanographic changes in the eastern Equatorial Pacific Ocean from 4 to 2 Ma (LEG 138, Sites 849 and 852). Proc. ODP, Sci. Results, 138: College Station, TX (Ocean Drilling Program), 163-175.

Flores, J.A., Gersonde, R., Sierro, F.J., 1999. Pleistocene fluctuations in the Agulhas Current Retroflection based on the calcareous plankton record. Marine Micropaleontology, 37: 1-22.

Flores, J.A., Sierro, F.J., Gersonde, R., 2002. Calcareous plankton stratigraphy around the Pliocene "Eltanin" asteroid impact area (SE Pacific): documentation and application for geological and paleoceanographic reconstruction. Deep Sea Research Part II: Topical Studies in Oceanography, 49(6): 1011-1027.

Flores, J.A., Sierro, F. J., 1997. Revised technique for calculation of calcareous nannofossil accumulation rates. Micropaleontology, 43: 321-324. 
Gallagher, S.J., Greenwood, D.R., Taylor, D., Smith, A.J., Wallace, M.W., Holdgate, G.R., 2003. The Pliocene climatic and environmental evolution of southeastern Australia: evidence from the marine and terrestrial realm. Palaeogeography, Palaeoclimatology, Palaeoecology, 193(3-4): 349-382.

Gard, G., Backman, J., 1990. Synthesis of Arctic and Sub-Arctic coccolith biochronology and History of North Atlantic drift water influx during the last 500,000 years. In: U. Bleil and J. Thiede (Editors), Geological History of the Polar Ocens: Arctic versus Antarctic. Kluwer, pp. 417-436.

Gard, G.Crux, J.A., 1991. Preliminary results from hole 704A: Arctic-Antarctic correlation through nannofossil Biochronology. In: P.F. Ciesielski and Y. Kristoffersen (Editors), Proceedings of the Ocean Drilling Program, Scientific Results, Vol. 114, pp. 194 -200.

Gartner, S., 1988. Paleoceanography of the mid-Pleistocene. Marine Micropaleontology, 13(1): 23-46.

Gartner, S., Chow, J., Stanton Jr, R.J., 1987. Late Neogene paleoceanography of the eastern Caribbean, the Gulf of Mexico, and the eastern Equatorial Pacific. Marine Micropaleontology, 12: 255-304.

Geisen, M., Billard, C., Broerse, A.T.C., Cros, L., Probert, I., Young, J.R., 2002. Life-cycle associations involving pairs of holococcolithophorid species: intraspecific variation or cryptic speciation? European Journal of Phycology, 37(4): 531-550.

Geitzenauer, K.R., 1969. Coccoliths as late Quaternary paleoclimatic indicators in the Subantarctic Pacific Ocean. Nature, 223: 170-172.

Geitzenauer, K.R., 1972. The Pleistocene calcareous nannoplankton of the subantarctic Pacific Ocean. Deep Sea Research, 19: 45-60.

Geitzenauer, K.R., Roche, M.B., McIntyre, A., 1976. Modern Pacific coccolith assemblages: derivation and application to Late Pleistocene palaeotemperature analysis. Geol. Soc. Am. Memoir, 145: 423-448.

Gersonde, R., Bárcena, M.A., 1998. Revision of the upper Pliocene-Pleistocene diatom biostratigraphy for the northern belt of the Southern Ocean. Micropaleontology, 44: 84-98.

Gersonde, R., Hodell, D.A., Blum, P., 1999a. Leg 177 summary: southern ocean paleoceanography. Proc. ODP, Init. Repts 177: College Station, TX (Ocean Drilling Program), 1-67.

Gersonde, R., Hodell, D.A., Blum, P., 2003. Proc. ODP, Sci. Results, 177: College Station, TX (Ocean Drilling Program).

Gersonde, R., Hodell, D.A., Blum, P., 1999b. Proc. ODP, Init. Repts., 177: College Station, TX (Ocean Drilling Program).

Gersonde, R., Kyte, F.T., Bleil, U., Diekmann, B., Flores, J.A., Gohl, K., Grahl, G., Hagen, R., Kuhn, G., Sierro, F.J., Volker, D., Abelmann, A., Bostwick, J.A., 1997. Geological record and reconstruction of the late Pliocene impact of the Eltanin asteroid in the Southern Ocean. Nature, 390(658): 357363.

Gersonde, R., Kyte, F.T., Frederichs, T., Bleil, U., Schenke, H.W., Kuhn, G., 2005. The late Pliocene impact of the Eltanin asteroid into the Southern Ocean-Documentation and environmental consequences. Geophysical Research Abstracts, 7: 02449.

Gibbard, P.L., Head, M.J., Walker, M.J.C., 2010. Formal ratification of the Quaternary System/Period and the Pleistocene Series/Epoch with a base at 2.58 Ma. Journal of Quaternary Science, 25(2): 96102.

Giraudeau, J., Rogers, J., 1994. Phytoplankton biomass and sea-surface temperature estimates from seabed distribution of nannofossils and planktonic foraminifera in the Benguela upwelling system. Micropaleontology, 40(3): 275-285.

Goddard, L., Graham, N.E., 1999. Importance of the Indian Ocean for simulating rainfall anomalies over eastern and southern Africa. J. Geophys. Res., 104(D16): 19099-19116.

Godfrey, J.S., 1996. The effect of the Indonesian throughflow on ocean circulation and heat exchange with the atmosphere: A review. J. Geophys. Res., 101(C5): 12217-12237.

Gordon, A.L., 1985. Indian-Atlantic Transfer of Thermocline Water at the Agulhas Retroflection. Science, 227(4690): 1030-1033.

Gordon, A.L., Fine, R.A., 1996. Pathways of water between the Pacific and Indian oceans in the Indonesian seas. Nature, 379(6561): 146-149.

Gordon, A.L., Susanto, R.D., Ffield, A., 1999. Throughflow within Makassar Strait. Geophys. Res. Lett., 26(21): 3325-3328. 
Hammer, Ø., Harper, D.A.T., Ryan, P.D., 2001. PAST: Paleontological Statistics software package for education and data analysis. Paleontol. Electronica 4(1): 9.

Hastenrath, S., Nicklis, A., Greischar, L., 1993. Atmospheric-Hydrospheric Mechanisms of Climate Anomalies in the Western Equatorial Indian Ocean. J. Geophys. Res., 98(C11): 20219-20235.

Haug, G.H., Ganopolski, A., Sigman, D.M., Rosell-Mele, A., Swann, G.E.A., Tiedemann, R., Jaccard, S.L., Bollmann, J., Maslin, M.A., Leng, M.J., Eglinton, G., 2005. North Pacific seasonality and the glaciation of North America 2.7 million years ago. Nature, 433(7028): 821-825.

Haug, G.H., Sigman, D.M., Tiedemann, R., Pedersen, T.F., Sarnthein, M., 1999. Onset of permanent stratification in the subarctic Pacific Ocean. Nature, 401(6755): 779-782.

Haug, G.H., Tiedemann, R., 1998a. Effect of the formation of the Isthmus of Panama on Atlantic Ocean Thermohaline Circulation. Nature, 393: 673-676.

Haug, G.H., Tiedemann, R., Zahn, R., Ravelo, A.C., 2001. Role of Panama uplift on oceanic freshwater balance. Geology, 29(3): 207-210.

Haug, G.H., Tiedemann, Keigwin, L. D. Jr., 2004. How the Isthmus of Panama Put Ice in the Arctic. Drifting continents open and close gateways between oceans and shift Earth's climate., Oceanus Magazine. Woods Hole Oceanographic Institution, Woods Hole, MA, pp. 1-4.

Hay, W.W., 1970. Calcareous nannofossils from cores recovered on Leg 4. Initial Reports Deep Sea Drilling Project 4: 455-501.

Hay, W.W., Soeding, E., DeConto, R.M., Wold, C.N., 2002. The late Cenozoic uplift-climate change paradox. Internation Journal of Earth Science (Geol Rundsch), 91: 746-774.

Haywood, A.M., Dowsett, H.J., Valdes, P.J., Lunt, D.J., Francis, J.E., Sellwood, B.W., 2009. Introduction. Pliocene climate, processes and problems. Philosophical Transactions of the Royal Society A, 367: 3-17.

Haywood, A.M., Valdes, P.J., 2004. Modelling Pliocene warmth: contribution of atmosphere, oceans and cryosphere. Earth and Planetary Science Letters, 218(3-4): 363-377.

Henrich, R., Baumann, K.H., Gerhardt, S., Gröger, M., Volbers, A., 2003. Carbonate preservation in Deep and Intermediate Water Masses in the South Atlantic: Evaluation and Geological Record (a Review). In: G. Wefer, S. Mulitza and V. Ratmeyer (Editors), The South Atlantic in the Late Quaternary: Reconstruction of Material Budgets and Current Systems. Springer-Verlag, pp. 645-670.

Hibberd, D.J., 1976. The ultrastructure and taxonomy of the Chrysophyceae and Prymnesiophyceae (Haptophyceae): a survey with some new observations on the ultrastructure of the Chrysophyceae. . Botanical Journal of the Linnean Society, 72: 55-80.

Hill, D.J., Haywood, A.M., Hindmarsh, R.C.A., Valdes, P.J., 2007. Characterizing ice sheets during the Pliocene: evidence from data and models. In: M. Williams, A.M. Haywood, F.J. Gregory and D.N. Schmidt (Editors), Deep-time perspectives on climate change: marrying the signal from computer models and biological proxies. Geological Society of London, pp. 517-538.

Hiramatsu, C., De Deckker, P., 1997. The calcareous nannoplankton assemblages of surface sediments in the Tasman and Coral Seas. Palaeogeography, Palaeoclimatology, Palaeoecology, 131(3-4): 257285.

Hirst, A.C., Godfrey, J.S., 1993. The Role of Indonesian Throughflow in a Global Ocean GCM. Journal of Physical Oceanography, 23(6): 1057-1086.

Hodell, D.A., Müller, D.W., Ciesielski, P.F., Mead, G.W., 1991. Synthesis of oxygen and carbon isotopic results from site 704: Implications for major climatic-geochemical transitions during the late Neogene. In: P.F. Ciesielski and Y. Kristoffersen (Editors), Proc. ODP, Sci. Results, 114:. College Station, TX (Ocean Drilling Program), 475-480.

Hodell, D.A., Venz, K.A., 1992. Toward a high-resolution stable isotopic record of the Southern Ocean during the Pliocene-Pleistocene (4.8-0.8 Ma). Antarct. Res. Ser., 56: 256-310.

Honjo, S., 1975. Dissolution of suspended coccoliths in the deep-sea water column and sedimentation of coccolith ooze. In: W.B. Sliter, A.W.H. Bé and W.H. Berger (Editors), Dissolution of Deep-Sea carbonates. Cushman found. Foraminiferal Res., pp. 115-28.

Howard, W.R., Prell, W.L., 1994. Late Quaternary $\mathrm{CaCO}_{3}$ production and preservation in the Southern Ocan: Implications for oceanic and atmospheric carbon cycling. Paleoceanography, 9(3): 453-482. 
IPCC, 2007. Climate Change 2007: The Physical Science Basis. Contribution of Working Group I to the Fourth Assessment Report of the Intergovernmental Panel on Climate Change, Cambrigde, 996 pp.

Jia, G., Chen, F., Peng, P.A., 2008. Sea surface temperature differences between the western equatorial Pacific and northern South China Sea since the Pliocene and their paleoclimatic implications. Geophys. Res. Lett., 35(18): L18609.

Karas, C., Nürnberg, D., Tiedemann, R., Garbe-Schönberg, D., 2010. Pliocene climate change of the Southwest Pacific and the impact of ocean gateways. Earth and Planetary Science Letters, 301(1-2): $117-124$.

Kawachi, M., Inouye, I., Maeda, O., Chihara, M., 1991. The haptonema as a food capturing device: observation Chrysochromulina hirta (Prymnesiophyceae). Phycologia, 30(6): 563-573.

Kim, S.J., Crowley, T.J., 2000. Increased Pliocene North Atlantic Deep Water: Cause or Consequence of Pliocene Warming? Paleoceanography, 15(4): 451-455.

Klaveness, D., Paasche, E., 1979. Physiology of coccolithophorids. In: M. Levandowsky and S.H. Hunter (Editors), Biochemistry and Physiology of Protozoa. Academic Press, New York, pp. 191-213.

Knappertsbusch, M., 2000. Morphologic evolution of the coccolithophorid Calcidiscus leptoporus from the upper Oligocene to Recent. Journal of Paleontology, 74(3): 712-730.

Kürschner, W.M., van der Burgh, J., Visscher, H., Dilcher, D.L., 1996. Oak leaves as biosensors of late neogene and early pleistocene paleoatmospheric $\mathrm{CO}_{2}$ concentrations. Marine Micropaleontology, 27(1-4): 299-312.

Kyte, F.T., 2001. Data Report: A search for deposits of the late Pliocene impact of the Eltanin asteroid in rise sediments from the Antarctic Peninsula, Site 1096. In: P.F. Barker, A. Camerlenghi, G.D. Acton and A.T.S. Ramsay (Editors), Proc. ODP, Sci. Results, 178: College Sation, TX (Ocean Drilling Program), 1-6.

Kyte, F.T., Zhou, Z., Wasson, J.T., 1981. High noble metal concentrations in a late Pliocene sediment. Nature, 292(5822): 417-420.

Latimer, J.C., Filippelli, G.M., 2001. Terrigenous Input and Paleoproductivity in the Southern Ocean. Paleoceanography, 16(6): 627-643.

Le, J., Shackleton, N.J., 1992. Carbonate dissolution fluctuations in the western equatorial Pacific during the late Quaternary. Paleoceanography, 7(1): 21-42.

Le Roux, J.P., Nielsen, S.N., Kemnitz, H., Henriquez, Á., 2008. A Pliocene mega-tsunami deposit and associated features in the Ranquil Formation, southern Chile. Sedimentary Geology, 203(1-2): 164180.

Leadbeater, B.S.C., 1971. Observations by means of cine photography on the behavior of the haptonema in plankton flagellates of the class Haptophyceae. J. Mar. Biol. Assn., 51: 207-217.

Lear, C.H., Rosenthal, Y., Wright, J.D., 2003. The closing of a seaway: ocean water masses and global climate change. Earth and Planetary Science Letters, 210(3-4): 425-436.

Lee, S.Y., Chiang, J.C.H., Matsumoto, K., Tokos, K.S., 2011. Southern Ocean wind response to North Atlantic cooling and the rise in atmospheric $\mathrm{CO}_{2}$ : Modeling perspective and paleoceanographic implications. Paleoceanography, 26(1): PA1214, 16 pp.

Leibniz Institute of Marine Sciences (IFM-GEOMAR), 2009. From Greenhouse To Ice House: Important Role Of The Indonesian Gateway Suggested. ScienceDaily.

Lisiecki, L.E., Raymo, M.E., 2005. A Pliocene-Pleistocene stack of 57 globally distributed benthic ${ }^{18} \mathrm{O}$ records. Paleoceanography, 20: 1003.

Liu, H., Probert, I., Uitz, J., Claustre, H., Aris-Brosou, S., Frada, M., Not, F., de Vargas, C., 2009. Extreme diversity in noncalcifying haptophytes explains a major pigment paradox in open oceans. Proceedings of the National Academy of Sciences, 106(31): 12803-12808.

Liu, Z., Altabet, M.A., Herbert, T.D., 2008. Plio-Pleistocene denitrification in the eastern tropical North Pacific: Intensification at 2.1 Ma. Geochem. Geophys. Geosyst., 9(11): Q11006, 14 pp..

Lundelius, E.L.J., 1987. The North American Quaternary sequence. In: M.O. Woodburne (Editor), Cenozoic mammals of North America. University of California Press, pp. 211-235. 
Lunt, D., Valdes, P., Haywood, A., Rutt, I., 2008. Closure of the Panama Seaway during the Pliocene: implications for climate and Northern Hemisphere glaciation. Climate Dynamics, 30(1): 1-18.

Lutjeharms, J.R.E., 1981. Spatial scales and intensities of circulation in the ocean areas adjacent to South Africa. Deep Sea Research Part A. Oceanographic Research Papers, 28(11): 1289-1302.

Lutjeharms, J.R.E., 1985. Location of frontal systems between Africa and Antarctica: some preliminary results. Deep Sea Research Part A Oceanographic Research Papers, 32(12): 1499-1509.

Lutjeharms, J.R.E., Valentine, H.R., 1984. Southern Ocean thermal fronts of Africa. Deep Sea Research Part A Oceanographic Research Papers, 31(12): 1461-1475.

Marlow, J.R., Lange, C.B., Wefer, G., Rosell-Melé, A., 2000. Upwelling Intensification As Part of the PliocenePleistocene Climate Transition. Science, 290(5500): 2288-2291.

Marshall, L.G., 1988. Land mammals and the Great American Interchange. American Scientist, 76: 380388.

Marshall, L.G., Webb, S.D., Sepkoski, J.J., Jr. Raup, D.M., 1982. Mammalian Evolution and the Great American Interchange. Science, 215(4538): 1351-1357.

Martinez, J.I., 1994. Late Pleistocene carbonate dissolution patterns in the Tasman Sea. In: G.J. van der Lingen, K.M. Swanson and R.J. Muir (Editors), Evolution of the Tasman Sea Basin. Balkema, Rotterdam, pp. 215-228.

Martini, E., 1971. Standard Tertiary and Quaternary calcareous nannoplankton zonation. In: A. Farinacci (Editor), Proceedings of the II Planktonic Conference. Ed. Tecnoscienza, Roma, pp. 739-785.

Maslin, M.A., Li, X.S., Loutre, M.F., Berger, A., 1998. The contribution of Orbital forcing to the progressive intensification of Northern Hemisphere Glaciation. Quaternary Science Reviews, 17: 411-426.

Maslin, M.A., Haug, G.H., Sarnthein, M., Tiedemann, R., 1996. The progressive intensification of northern hemisphere glaciation as seen from the North Pacific. Geol. Rundsch., 85: 452-465.

Matsuoka, H., 1990. A new method to evaluate dissolution of $\mathrm{CaCO}_{3}$ in the deep-sea sediments. Trans. Proc. Paleont. Soc. Japan, 157: 430-434.

McIntyre, A., Bé, A.W.H., 1967. Modern coccolithophoridae of the Atlantic Ocean I. Placoliths and cyrtoliths. Deep Sea Research, 14: 561 - 579.

McIntyre, A., Bé, A., Roche, M., 1970. Modern Pacific coccolithophorida: a paleontological thermometer. Transactions of the New York Academy of Sciences II 32/6: 720-731.

Meschede, M., Frisch, W., 1998. A plate-tectonic model for the Mesozoic and Early Cenozoic history of the Caribbean plate. Tectonophysics, 296(3-4): 269-291.

Meschede, M., Zweigel, P., Kiefer, E., 1999. Subsidence and extension at a convergent plate margin: evidence for subduction erosion off Costa Rica. Terra Nova, 11(2-3): 112-117.

Milankovitch, M., 1941. History of radiation on the earth and its use for the problem of the ice ages. Serb. Akad. Beogr. Spec. Publ, 132.

Miller, K.G., Kominz, M.A., Browning, J.V., Wright, J.D., Mountain, G.S., Katz, M.E., Sugarman, P.J., Cramer, B.S., Christie-Blick, N., Pekar, S.F., 2005. The Phanerozoic Record of Global Sea-Level Change. Science, 310(5752): 1293-1298.

Mix, A.C., Pisias, N.G., Rugh, W., Wilson, J., Morey, A., Hagelberg, T.K., 1995. Benthic foraminifer stable isotope record from Site 849 (0-5 Ma): Local and global climate changes. In: N.G. Pisias, L.A. Mayer, T.R. Janecek, A. Palmer-Julson and T.H. Van Andel (Editors), Proc. ODP, Sci. Results, 138: College Station, TX (Ocean Drilling Program), 371-412.

Mohan, R., Mergulhao, L.P., Guptha, M.V.S., Rajakumar, A., Thamban, M., AnilKumar, N., Sudhakar, M., Ravindra, R., 2008. Ecology of coccolithophores in the Indian sector of the Southern Ocean. Marine Micropaleontology, 67(1-2): 30-45.

Narciso, A., Cachão, M., de Abreu, L., 2006. Coccolithus pelagicus subsp. pelagicus versus Coccolithus pelagicus subsp. braarudii (Coccolithophore, Haptophyta): A proxy for surface subarctic Atlantic waters off Iberia during the last 200 kyr. Marine Micropaleontology, 59(1): 15-34.

Nelson, G., 1989. Poleward motion in the Benguela area. In: S.J. Neshyba, C.N.K. Mooers, R.L. Smith and R.T. Barber (Editors), Poleward flows along eastern ocean boundaries. Springer, New York, pp. 110-130.

Nürnberg, D., Groeneveld, J., 2006. Pleistocene variability of the Subtropical Convergence at East Tasman Plateau: Evidence from planktonic foraminiferal Mg/Ca (ODP Site 1172A). Geochem. Geophys. 
Geosyst., 7(4): Q04P11.

Okada, H., 2000. Neogene and Quaternary calcareous nannofossils from the Blake Ridge, Sites 994, 995, and 997. In: C.K. Paull, R. Matsumoto, P.J. Wallace and W.P. Dillon (Editors), Proc. ODP, Sci. Results, 164: College Station, TX (Ocean Drilling Program), 331-341.

Okada, H., Honjo, S., 1973. The distribution of oceanic coccolithophorids in the Pacific. Deep-Sea Research and oceanographic Abstracts, 20(4): 355-374.

Okada, H., McIntyre, A., 1977. Modern Coccolithophores of the Pacific and North Atlantic Oceans. Micropaleontology, 23(1): 1-55.

Okada, H., McIntyre, A., 1979. Seasonal distribution of modern coccolithophores in the western North Atlantic Ocean. Marine Biology, 54(4): 319-328.

Okada, H. Wells, P., 1997. Late Quaternary nannofossil indicators of climate change in two deep-sea cores associated with the Leeuwin Current off Western Australia. Palaeogeography, Palaeoclimatology, Palaeoecology, 131: 413-432.

Orsi, A.H., Whitworth, T., Nowlin, W.D., 1995. On the meridional extent and fronts of the Antarctic Circumpolar Current. Deep Sea Research Part I: Oceanographic Research Papers, 42(5): 641-673.

Paillard, D., Labeyrie, L., Yiuo, P., 1996. Macintosh program performs time-series analysis. EOS Transactions AGU 77 (1996): p. 379.

Parente, A., Cachão, M., Baumann, K.H., de Abreu, L., Ferreira, J., 2004. Morphometry of Coccolithus pelagicus s.l. (Coccolithophore, Haptophyta) from offshore Portugal, during the last $200 \mathrm{kyr}$. Micropaleontology, 50: 107-120.

Pearson, P.N., Palmer, M.R., 2000. Atmospheric carbon dioxide concentrations over the past 60 million years. Nature, 406(6797): 695-699.

Peterson, L.C., Prell, W.L., 1985. Carbonate dissolution in recent sediments of the eastern equatorial Indian Ocean: preservation patterns and carbonate loss above the lysocline. Marine Geology, 64: 259290.

Peterson, R.G., Stramma, L., 1991. Upper-level circulation in the South Atlantic Ocean. Progress In Oceanography, 26(1): 1-73.

Poore, R.Z., 2007. Pliocene environments. In: S.A. Elias (Editor), Encyclopedia of Quaternary Science. Elsevier, London, pp. 1948-1958.

Pujos, A., 1985. Nannofosssils from Quaternary deposits in the high-productivity area of the central equatorial Pacific, Deep sea Drilling Project Leg 85. Initial Reports of the Deep Sea Drilling Project, 85: 553-580.

Quinn, P.S., Sáez, A.G., Baumann, K.H., Steel, B.A., Sprengel, C.,Medlin, L.K., 2004. Coccolithophorid biodiversity: evidence from the cosmopolitan species Calcidiscus leptoporus. In: H.R. Thierstein and J.R. Young (Editors), Coccolithophores, from Molecular Processes to Global Impact. Springer, pp. 299-326.

Raffi, I., 2002. Revision of the early-middle Pleistocene calcareous nannofossil biochronology (1.75-0.85 Ma). Marine Micropaleontology, 45(1): 25-55.

Raffi, I., Backman, J., Fornaciari, E., Pälike, H., Rio, D., Lourens, L., Hilgen, F., 2006. A review of calcareous nannofossil astrobiochronology encompassing the past 25 million years. Quaternary Science Reviews, 25: 3113-3137.

Raffi, I., Backman, J., Rio, D., Shackleton, N.J., 1993. Plio-Pleistocene Nannofossil Biostratigraphy and Calibration to Oxygen Isotope Stratigraphies from Deep Sea Drilling Project Site 607 and Ocean Drilling Program Site 677. Paleoceanography, 8(3): 387-408.

Raffi, I., Rio, D., 1981. Coccolithus pelagicus (wallich): a paleaotemperature indicator in the late Pliocene Mediterranean deep sea record. In: F.C. Wezel (Editor), Sedimentary Basin of Mediterranean Margins, pp. 187-190.

Ravelo, A.C., Andreasen, D.H., Lyle, M., Lyle, A.O., Wara, M.W., 2004. Regional climate shifts caused by gradual global cooling in the Pliocene Epoch. Nature, 429: 263-267.

Ravelo, A.C., Dekens, P.S., McCarthy, M., 2006. Evidence for El Niño-like conditions during the Pliocene. GSA today, 16: 4-11. 
Raymo, M.E., Grant, B., Horowitz, M., Rau, G.H., 1996. Mid-Pliocene warmth: stronger greenhouse andstronger conveyor. Marine Micropaleontology, 27: 313-326.

Raymo, M.E., Rau, G.H., 1992. Plio-Pleistocene atmospheric $\mathrm{CO}_{2}$ levels inferred from POM $\delta^{13} \mathrm{C}$ at DSDP Site 607. EOS, Trans. Am. Geophys. Union, Spring Meet. 73 (suppl): 95.

Reid, J.L., 1989. On the geostrophic circulation of the South Atlantic Ocean: Flow patterns, tracers, and transports. Progresive Oceanography, 23: 149-244.

Reverdin, G., Cadet, D.L., Gutzler, D., 1986. Interannual displacements of convection and surface circulation over the equatorial Indian Ocean. Quarterly Journal of the Royal Meteorological Society, 112(471): 43-67.

Rind, D., 1998. Latitudinal temperature gradients and climate change. J. Geophys. Res., 103(D6): 59435971.

Rintoul, S.R., Hughes, C.O, lbers, D., 2001. The Antarctic Circumpolar Current System. In: G. Siedler, J. Church and J. Gould (Editors), Ocean Circulation \& Climate. Observing and modeling in the Global Ocean. Academic Press, pp. 271-302.

Roth, P.H., Mullin, M.M., Berger, W.H., 1975. Coccolith sedimentation by fecal pellets: laboratory experiment and field observations. Geological Society of America Bulletin, 86(8): 1079-84.

Roth, P.H., Thierstein, H.R., 1972. Calcareous nannoplankton; leg 14 of the Deep Sea Drilling Project, Initial Reports of the Deep Sea Drilling Project; Lisbon, Portugal to San Juan, Puerto Rico. Texas A \& M University, Ocean Drilling Program, College Station, TX, United States, pp. 421-486.

Sabaa, A.T., Sikes, E.L., Hayward, B.W., Howard, W.R., 2004. Pliocene sea surface temperature changes in ODP Site 1125, Chatham Rise, east of New Zealand. Marine Geology, 205(1-4): 113-125.

Sáez, A.G., Probert, I., Geisen, M., Quinn, P., Young, J.R., Medlin, L.K., 2003. Pseudo-cryptic speciation in coccolithophores. Proceedings of the National Academy of Sciences of the United States of America, 100(12): 7163-7168.

Salzmann, U., Haywood, A.M., Lunt, D.J., 2009. The past is a guide to the future? Comparing Middle Pliocene vegetation with predicted biome distributions for the twenty-first century. Philosophical Transactions of the Royal Society A: Mathematical, Physical and Engineering Sciences, 367(1886): 189-204.

Samtleben, C., 1980. Die Evolution der Coccolithophoriden-Gattung Gephyrocapsa nach Befunden im Atlantik. Paläont. Z., 54: 91-127.

Sato, T., Saito, T., Yuguchi, S., Nakagawa, H., Kameo, K., Takayama, T., 2002. Late Pliocene calcareous nannofossil paleobiogeography of the Pacific Ocean: Evidence for glaciation at 2.75 Ma. Revista Mexicana de Ciencias Geológica, 19(3): 175-189.

Sato, T., Yuguchi, S., Takayama, T., Kameo, K., 2004. Drastic change in the geographical distribution of the cold-water nannofossil Coccolithus pelagicus (Wallich) Schiller at $2.74 \mathrm{Ma}$ in the late Pliocene, with special reference to glaciation in the Arctic Ocean. Marine Micropaleontology, 52(1-4): 181-193.

Schlitzer, R., 2011. Ocean Data View. http://odv.awi.de.

Schneider, B., Schmittner, A., 2006. Simulating the impact of the Panamanian seaway closure on ocean circulation, marine productivity and nutrient cycling. Earth and Planetary Science Letters, 246(3-4): 367-380.

Schneidermann, N., 1977. Selective dissolution of Recent coccoliths in the Atlantic Ocean. In: A.T.S. Ramsay (Editor), Oceanic Micropaleontology. Academic Press, New York, pp. 1009-1053.

Shipboard Scientific Party, 1999. Site 1090. In: R. Gersonde, D.A. Hodell, P. Blum et al. (Editors), Proc. ODP, Init. Repts., 177: College Station, TX (Ocean Drilling Program), 1-101.

Shipboard Scientific Party, 2001. Site 1172. In: N.F. Exon, J.P. Kennett, M.J. Malone et al. (Editors), Proc. ODP, Init. Repts, 189: College Station, TX (Ocean Drilling Program), 1-167.

Shackleton, N.J., Opdyke, N., 1973. Oxygen isotopic and paleomagneticstratigraphy of equatorial Pacific core V28-238; oxygen isotope temperatures and ice volumes on a $10^{5}$ and $10^{6}$ year scale. . Quaternary Research, 3:39-55.

Sigman, D.M., Jaccard, S.L., Haug, G.H., 2004. Polar ocean stratification in a cold climate. Nature, 428(6978): 59-63. 
Sikes, E.L., Howard, W.R., Neil, H.L., Volkman, J.K., 2002. Glacial-interglacial sea surface temperature changes across the subtropical front east of New Zealand based on alkenone unsaturation ratios and foraminiferal assemblages. Paleoceanography, 17(2): 1012, 13 pp..

Sikes, E.L., Keigwin, L.D., Curry, W.B., 1991. Pliocene Paleoceanography: Circulation and Oceanographic Changes Associated with the $2.4 \mathrm{Ma}$ Glacial Event. Paleoceanography, 6(2): 245-257.

Sloan, L.C., Crowley, T.J., Pollard, D., 1996. Modeling of middle Pliocene climate with the NCAR GENESIS general circulation model. Marine Micropaleontology, 27(1-4): 51-61.

Sokolov, S., Rintoul, S.R., 2002. Structure of Southern Ocean fronts at $140^{\circ}$ E. Journal of Marine Systems, 37(1-3): 151-184.

Speich, S., Ganachaud, A., Marsh, R., 2002. Tasman leakage: A new route in the global conveyer belt. Geophys. Res. Letters, 29: 1416, 4 pp.

Steinmetz, J.C., 1994. Sedimentation of coccolithophores. In: A. Winter and W.G. Siesser (Editors), Coccolithophores. Cambridge University Press, pp. 179-197.

Steph, S., 2005. Pliocene stratigraphy and the impact of the Panama uplift on changes in the Caribbean and tropical East Pacific upper stratification (6-2.5 Ma.), der Christian-Albrechts-Universität, Kiel.

Stickley, C.E., Brinkhuis, H., McGonigal, K.L., Chaproniere, G.C.H., Fuller, M., Kelly, D.C., Nürnberg, D., Pfuhl, H.A., Schellenberg, S.A., Schoenfeld, J., Suzuki, N., Touchard, Y., Wei, W., Williams, G.L., Lara, J., Stant, S.A., 2004. Late Cretaceous-Quaternary biomagnetostratigraphy of ODP Sites 1168, 1170, 1171, and 1172, Tasmanian Gateway. In: N.F. Exon, J.P. Kennett and M.J. Malone (Editors), Proc. ODP, Sci. Results, 189: College Station, TX (Ocean Drilling Pogram), 1-57.

Stramma, L., Ikeda, Y., Peterson, R.G., 1990. Geostrophic transport in the Brazil current region north of $20^{\circ}$ S. Deep Sea Research Part A. Oceanographic Research Papers, 37(12): 1875-1886.

Takahashi, K., Okada, H., 2000a. Environmental control on the biogeography of modern coccolithophores in the southeastern Indian Ocean offshore of Western Australia. Marine Micropaleontology, 39(14): 73-86.

Takahashi, K., Okada, H., 2000b. The paleoceanography for the last 30,000 years in the southeastern Indian Ocean by means of calcareous nannofossils. Marine Micropaleontology, 40(1-2): 83-103.

Takahashi, K, .Okada, H., 2001. Paleoceanography for the last 195,000 years in the Solomon Sea (ODP Site 1109) by means of calcareous nannofossils. Marine Micropaleontology, 42(1-2): 45-59.

Thierstein, H.R., Geitzenauer, K.R., Molfino, B., Shackleton, N.J., 1977. Global synchronicity of late Quaternary coccolith datum levels: validation by oxygen isotopes. Geology, 5: 400-404.

Thierstein, H.R., Young, J.R., 2004. Coccolithophores from Molecular Processes to Global Impact. Springer, Berlin, 565 pp.

Thompson, R.S., 1991. Pliocene environments and climates in the western United States. Quaternary Science Reviews, 10(2-3): 115-132.

Thompson, R.S., Fleming, R.F., 1996. Middle Pliocene vegetation: reconstructions, paleoclimatic inferences, and boundary conditions for climate modeling. Marine Micropaleontology, 27(1-4): 27-49.

Thunell, R.C., 1976. Optimum indices of calcium carbonate dissolution in deep-sea sediments. Geology, 4: 525-527.

Tiedemann, R., Sarnthein, M., Shackleton, N.J., 1994. Astronomic timescale for the Pliocene Atlantic $\delta^{18} \mathrm{O}$ and dust flux records of Ocean Drilling Program site 659. Paleoceanography, 9: 619-638.

Tomzack, M., Godfrey, S.J., 2003. Regional Oceanography: An introduction, second edition. Pergamon, 390 pp..

Toon, O.B., Zahnle, K., Morrison, D., Turco, R.P., Covey, C., 1997. Environmental Perturbations Caused by the Impacts of Asteroids and Comets. Reviews of Geophysics, 35(1): 41-87.

Van Der Burgh, J., Visscher, H., Dilcher, D.L., Kurschner, W.M., 1993. Paleoatmospheric Signatures in Neogene Fossil Leaves. Science, 260(5115): 1788-1790.

Venz, K.A., Hodell, D.A., 2002. New evidence for changes in Plio-Pleistocene deep water circulation from Southern Ocean ODP Leg 177 Site 1090. Palaeogeography, Palaeoclimatology, Palaeoecology, 182(3-4): 197-220.

Wang, L., 1994. Sea surface temperature history of the low latitude western Pacific during the last 5.3 million years. Palaeogeography, Palaeoclimatology, Palaeoecology, 108(3-4): 379-425, 435-436. 
Wara, M.W., Ravelo, A.C., Delaney, M.L., 2005. Permanent El Nino-Like Conditions During the Pliocene Warm Period. Science, 309(5735): 758-761.

Ward, S.N., Asphaug, E., 2002. Impact tsunami-Eltanin. Deep Sea Research Part II: Topical Studies in Oceanography, 49(6): 1073-1079.

Webb, S.D., 1985. Late Cenozoic mammal dispersals between the Americas. In: F.G. Stehli and S.D. Webb (Editors), The Great American Biotic Interchange. Plenum Press, New York, pp. 357-386.

Wei, W., 1993. Calibration of Upper Pliocene-Lower Pleistocene Nannofossil Events with Oxygen Isotope Stratigraphy. Paleoceanography, 8(1): 85-99.

Wei, K.Y., 1998. Southward shifting of the Tasman Front at 4.4 Ma (early Pliocene): paleobiogeographic and oxygen isotope evidence. Journal of Asian Earth Science, 16(1): 97-106.

Wells, P., Okada, H., 1996. Holocene and Pleistocene glacial palaeoceanography off southeastern Australia, based on foraminifers and nannofossils in Vema cored hole V18-222. Australian Journal of Earth Science, 43: 509-523.

Wells, P., Okada, H., 1997. Response of nannoplankton to major changes in sea-surface temperature and movements of hydrological fronts over Site DSDP 594 (south Chatham Rise, southeastern New Zealand), during the last $130 \mathrm{kyr}$. Marine Micropaleontology, 32(3-4): 341-363.

Wells, P.E., Connell, R., 1997. Movement of the hydrological fronts and widespread erosional events in the southwestern Tasman Sea during the late Quaternary. Australian Journal of Earth Science, 44: 105-112.

Whitehead, J.M., Hardwood, D.M., McKelvey, B.C., Hambrey, M.J., McMinn, A., 2004. Diatom biostratigraphy of the Cenozoic fjordal Pagadroma Group, northern Prince Charles Mountains, East Antarctica. Australian Journal of Earth Science, 51: 521-547.

Winter, A., Siesser, W.G., 1994. Coccolithophores. Cambridge University Press, 242 pp.

Wise, S.W.J., 2000. The Antarctic ice sheet: Rise and Demise. Journal of Land use and environmental law, 15(summer): 383-422.

Wolf, T.C.W., Thiede, J., 1991. History of terrigenous sedimentation during the past $10 \mathrm{my}$ in the North Atlantic (ODP-Leg's 104, 105 and DSDP-Leg 81). Marine Geology, 101: 83-102.

Young, J., Geisen, M., Cros, L., Kleijne, A., Sprengel, C., Probert, I., 2003. A guide to extant calcareous nannoplankton taxonomy. Journal of Nannoplankton Research, 1: 1-125.

Young, J.R., 1994. Functions of coccoliths. In: A. Winter and W.G. Siesser, (Editors), Coccolithophores. Cambridge University Press, pp. 63-82.

Ziveri, P., Baumann, K.H., Boeckel, B., Bollmann, J., Young, J.R., 2004. Biogeography of selected Holocene coccoliths in the Atlantic Ocean. In: H.R. Thierstein and J.R. Young (Editors), Coccolithophores, from molecular processes to a global impact. Springer, Berlin, pp. 403-428. 


\section{A ppendix}

APPENDIX A: list of abbreviations.

APPENDIX B: overview of studied samples 



\section{APPENDIX A: List of Abbreviations}

\begin{tabular}{|c|c|c|c|}
\hline AABW & Antarctic Bottom Water & SG & Small Gephyrocapsa \\
\hline AAIW & Antarctic Intermediate Water & SO & Southern Ocean \\
\hline $\mathrm{ACC}$ & Antarctic Circumpolar Current & SR & $\begin{array}{l}\text { Small Reticulofenestra }(3-5 \\
\mu \mathrm{m})\end{array}$ \\
\hline APC & Advanced Piston Corer & SST & Sea Surface Temperature \\
\hline CCD & Carbonate Compensation Depth & STCZ & $\begin{array}{l}\text { Subtropical Convergence } \\
\text { Zone }\end{array}$ \\
\hline CDW & Circumpolar Deep Water & STF & Subtropical Front \\
\hline CI & Complete individuals & THC & Thermohaline Circulation \\
\hline DL & Dissolution C. leptoporus & VSR & $\begin{array}{l}\text { Very Small Reticulofenestra }(< \\
3 \mu \mathrm{m})\end{array}$ \\
\hline DP & Dissolution C. pelagicus & WC & Walker Circulation \\
\hline EAC & East Australian Current & WEP & Western Equatorial Pacific \\
\hline EEP & Eastern Equatorial Pacific & WPWP & Western Pacific Warm Pool \\
\hline ENSO & El Niño Southern Oscilation & $\mathrm{XCB}$ & Extended Core Barrel \\
\hline FCO & First Common Occurrence & & \\
\hline FO & First Occurrence & & \\
\hline G & Glacial & & \\
\hline GCM & General Circulation Model & & \\
\hline HC & Hadley Circulation & & \\
\hline IPCC & $\begin{array}{l}\text { Intergovernmental Panel on Climate } \\
\text { Change }\end{array}$ & & \\
\hline IG & Interglacial & & \\
\hline ITCZ & Intertropical Convergence Zone & & \\
\hline $\mathbf{L M}$ & Light Microscope & & \\
\hline LO & Last Occurrence & & \\
\hline LR & 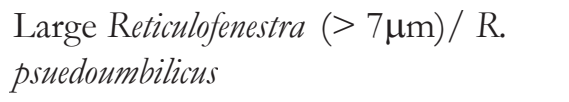 & & \\
\hline MIS & Marine Isotope Stage & & \\
\hline MPW & Mid Pliocene Warmth & & \\
\hline $\mathbf{M R}$ & Medium Reticulofenestra $(5-7 \mu \mathrm{m})$ & & \\
\hline NADW & Northern Atlantic Deep Water & & \\
\hline NAR & Nannofossil Accumulation Rate & & \\
\hline NCW & Northern Component Water & & \\
\hline NF & Number of Fragments & & \\
\hline NHG & Northern Hemisphere Glaciation & & \\
\hline ODP & Ocean Drilling Program & & \\
\hline PF & Polar Front & & \\
\hline PFZ & Polar Front Zone & & \\
\hline SAF & Subantarctic Front & & \\
\hline SAZ & Subantarctic Zone & & \\
\hline SCW & Southern Component Water & & \\
\hline SEM & Scanning Electron Microscope & & \\
\hline SF & Size of Fragments & & \\
\hline
\end{tabular}




\section{APPENDIX B: Overview of the studied samples}

Table 1. Sample overview ODP site 1090

\begin{tabular}{|c|c|c|c|c|c|c|c|}
\hline LEG & Site & Hole & Core & Section & Length $(\mathrm{cm})$ & $\begin{array}{l}\text { Depth (mcd) } \\
\text { (top - bottom) }\end{array}$ & $\begin{array}{l}\text { Sample resolution } \\
(\mathrm{cm})\end{array}$ \\
\hline 177 & 1090 & B & $5 \mathrm{H}$ & $\mathrm{CC}$ & 11 & $44.88-44.98$ & 10 \\
\hline 177 & 1090 & B & $6 \mathrm{H}$ & 1 & 140 & $43.81-45.20$ & 10 \\
\hline 177 & 1090 & B & $6 \mathrm{H}$ & 2 & 140 & $45.31-46.70$ & 10 \\
\hline 177 & 1090 & B & $6 \mathrm{H}$ & 3 & 140 & $46.81-48.20$ & 10 \\
\hline 177 & 1090 & B & $6 \mathrm{H}$ & 4 & 140 & $48.31-49.70$ & 10 \\
\hline 177 & 1090 & B & $6 \mathrm{H}$ & 5 & 140 & $49.81-51.20$ & 10 \\
\hline 177 & 1090 & B & $6 \mathrm{H}$ & 6 & 140 & $51.31-52.70$ & 10 \\
\hline 177 & 1090 & B & $6 \mathrm{H}$ & 7 & 50 & $52.80-53.30$ & 10 \\
\hline 177 & 1090 & $\mathrm{D}$ & $6 \mathrm{H}$ & 2 & 145 & $52.37-53.81$ & 5 \\
\hline 177 & 1090 & $\mathrm{D}$ & $6 \mathrm{H}$ & 3 & 145 & $53.87-55.31$ & 5 \\
\hline 177 & 1090 & $\mathrm{D}$ & $6 \mathrm{H}$ & 4 & 145 & $55.37-56.81$ & 5 \\
\hline 177 & 1090 & $\mathrm{D}$ & $6 \mathrm{H}$ & 5 & 145 & $56.87-58.31$ & 5 \\
\hline 177 & 1090 & B & $7 \mathrm{H}$ & $\mathrm{CC}$ & 10 & $65.48-65.57$ & 5 \\
\hline 177 & 1090 & B & $7 \mathrm{H}$ & 1 & 140 & $58.01-59.40$ & 10 \\
\hline 177 & 1090 & $\mathrm{~B}$ & $7 \mathrm{H}$ & 2 & 140 & $59.51-60.90$ & 10 \\
\hline 177 & 1090 & $\mathrm{~B}$ & $7 \mathrm{H}$ & 3 & 140 & $61.01-62.40$ & 10 \\
\hline 177 & 1090 & B & $7 \mathrm{H}$ & 4 & 140 & $62.51-63.90$ & 10 \\
\hline 177 & 1090 & B & $7 \mathrm{H}$ & 5 & 140 & $64.01-65.40$ & 10 \\
\hline 177 & 1090 & B & $8 \mathrm{H}$ & 1 & 30 & $64.92-65.21$ & 10 \\
\hline
\end{tabular}

Table 2. Sample overview ODP site 1172

\begin{tabular}{llllllll} 
LEG & Site & Hole & Core & Section & Length $\mathbf{( c m )}$ & $\begin{array}{l}\text { Depth } \mathbf{( m c d )} \\
\text { (top - bottom) }\end{array}$ & $\begin{array}{l}\text { Sample resolution } \\
\text { (cm) }\end{array}$ \\
\hline 189 & 1172 & A & $3 \mathrm{H}$ & 1 & 138 & $18.02-19.4$ & 10 \\
189 & 1172 & A & $3 \mathrm{H}$ & 2 & 148 & $19.60-21.00$ & 10 \\
189 & 1172 & A & $3 \mathrm{H}$ & 3 & 138 & $21.10-22.40$ & 10 \\
189 & 1172 & A & $3 \mathrm{H}$ & 4 & 148 & $22.52-24.00$ & 10 \\
189 & 1172 & A & $3 \mathrm{H}$ & 5 & 138 & $24.10-25.40$ & 10 \\
189 & 1172 & A & $3 \mathrm{H}$ & 6 & 148 & $25.52-27.00$ & 10 \\
189 & 1172 & A & $3 \mathrm{H}$ & 7 & 58 & $27.10-27.59$ & 10 \\
189 & 1172 & A & $4 \mathrm{H}$ & 1 & 138 & $27.20-28.60$ & 10 \\
189 & 1172 & A & $4 \mathrm{H}$ & 2 & 148 & $28.72-30.20$ & 10 \\
189 & 1172 & A & $4 \mathrm{H}$ & 3 & 138 & $30.20-31.60$ & 10 \\
189 & 1172 & A & $4 \mathrm{H}$ & 4 & 148 & $31.72-33.20$ & 10 \\
189 & 1172 & A & $4 \mathrm{H}$ & 5 & 138 & $33.30-34.60$ & 10 \\
189 & 1172 & A & $4 \mathrm{H}$ & 6 & 148 & $34.72-36.20$ & 10 \\
189 & 1172 & A & $4 \mathrm{H}$ & 7 & 68 & $36.30-36.89$ & 10 \\
189 & 1172 & B & $5 \mathrm{H}$ & 1 & 20 & $35.98-36.18$ & 10 \\
189 & 1172 & B & $5 \mathrm{H}$ & 2 & 148 & $36.30-37.77$ & 10 \\
189 & 1172 & A & $5 \mathrm{H}$ & 1 & 138 & $37.74-39.12$ & 10 \\
189 & 1172 & A & $5 \mathrm{H}$ & 2 & 148 & $39.24-40.72$ & 10 \\
189 & 1172 & A & $5 \mathrm{H}$ & 3 & 138 & $40.82-42.12$ & 10 \\
189 & 1172 & A & $5 \mathrm{H}$ & 4 & 148 & $42.24-43.72$ & 10 \\
189 & 1172 & A & $5 \mathrm{H}$ & 5 & 138 & $43.82-45.12$ & 10 \\
189 & 1172 & A & $5 \mathrm{H}$ & 6 & 148 & $45.24-46.72$ & 10 \\
189 & 1172 & A & $5 \mathrm{H}$ & 7 & 68 & $46.82-47.72$ & 10
\end{tabular}




\title{
Circum-Antarctic warming events between 4 and 3.5 Ma recorded in marine sediments from the Prydz Bay (ODP Leg 188) and the Antarctic Peninsula (ODP Leg 178) margins
}

\author{
C. Escutia ${ }^{\text {a,* }}$, M.A. Bárcena ${ }^{\text {b }}$, R.G. Lucchi ${ }^{\text {c }}$, O. Romero ${ }^{\text {a }}$, A.M. Ballegeer ${ }^{\text {b }}$, J.J. Gonzalez ${ }^{\text {a }}$, D.M. Harwood ${ }^{\text {d }}$ \\ a Instituto Andaluz de Ciencias de la Tierra, CSIC-Universidad de Granada, Fuentenueva s/n, 18002-Granada, Spain \\ ${ }^{\mathrm{b}}$ Universidad de Salamanca, Departamento de Geología, 37008 Salamanca, Spain \\ c GRC Geociències Marines, Departament d'Estratigrafia, P. i Geociències Marines, Universitat de Barcelona, Facultat de Geologia C/ Martí i Franquès, s/n, 08028-Barcelona, Spain \\ ' Department of Geosciences, University of Nebraska-Lincoln, P.O. Box 880340, Lincoln, NE 68588-0340, USA
}

\section{A R T I C L E I N F O}

\section{Article history:}

Received 25 March 2009

Accepted 22 September 2009

Available online 4 October 2009

\section{Keywords:}

early-middle Pliocene

glaciomarine sedimentation

Antarctic Peninsula

Prydz Bay

circum-Antarctic

glacial-interglacial cycles

\begin{abstract}
A B S T R A C T
Our study characterizes glacial and interglacial deposition on two Antarctic margins in order to discriminate between regional and continent-wide early to middle Pliocene warm intervals that caused sea-ice reduction and continental ice sheet retreat. We use a multi-proxy (i.e., sediment facies and grain size, siliceous microfossils, biogenic opal, geochemical composition and clay mineralogy) approach to examine sediments recovered in drill holes from the West Antarctic Peninsula and the East Antarctic Prydz Bay margins, focusing on the climatic record between 4 and $3.5 \mathrm{Ma}$.

Warm conditions in both East and West Antarctica are recorded, which based on our age model correspond to periods of prolonged or extreme warmth correlated with isotopic stages Gi5, Gi1, MG11 and MG7. For the Gi5 interglacial our data corroborates the 60\% Dictyocha percentage at $34.60 \mathrm{mbsf}$ previously reported from Prydz Bay and interpreted to indicate a SSST of about $5.6{ }^{\circ} \mathrm{C}$ above present. Our higher-resolution sampling interval shows Dictyocha percentages up to $87.5 \%$, suggesting even higher SSSTs above present levels. During MG11, which coincides with the section dated by the magnetic polarity reversal Gilbert-Gauss at 3.58 Ma, SSSTs were tentatively $2.5^{\circ}-4^{\circ}$ warmer than present, and reduced sea-ice cover in Prydz Bay and probably also west of the Antarctic Peninsula is indicated by increased primary productivity. In addition, a reduction of ice sheet size is suggested by the bioturbated and IRD-enriched facies that characterize these highproductivity intervals. Based in our age model and calculated sedimentation rates glacial-interglacial cyclicity between 4 and $3.5 \mathrm{Ma}$ in the cores from Antarctic Peninsula and Prydz Bay Sites, result in frequencies consistent with obliquity and precession forcing.

The prolonged early-middle Pliocene warm period was superimposed on a cooling trend recorded by the: 1) increase of the terrigenous sediment supply at all our sites starting between 3.7 and $3.6 \mathrm{Ma}$, and 2) decrease in SSSTs (from $>5.6{ }^{\circ} \mathrm{C}$ at $3.7 \mathrm{Ma}$ to $4^{\circ}-2.7^{\circ} \mathrm{C}$ at $3.6 \mathrm{Ma}$, and $2.5^{\circ} \mathrm{C}$ at $3.5 \mathrm{Ma}$.) indicated by the silicoflagellate W/C R from Site 1165. We postulate that, although the start of a cooling trend is recorded at about 3.7-3.6-Ma, relatively warm conditions prevailed until 3.5 Ma capable of maintained open marine conditions with reduced or no sea-ice and reduced ice sheet volume and extent.

The information in this paper regarding the timing of continental-wide and regional warm events and the paleoenvironmental conditions that characterized them (i.e., SSST, extent of sea ice, and ice sheet size) are relevant to help constrain paleoclimate and ice sheet models for the early-middle Pliocene, a time period when the level of warming according to the Intergovernmental Panel on Climate Change 2007 report, is within range of the estimates of the Earth's global temperature increases for the 21st century. These data, when linked to modeling studies like those of Pollard and DeConto (2009) will further our understanding of how these ice sheets may respond to future warming of the southern high latitudes.
\end{abstract}

(c) 2009 Elsevier B.V. All rights reserved.

\footnotetext{
* Corresponding author.

E-mail addresses: cescutia@ugr.es (C. Escutia), mbarcena@usal.es (M.A. Bárcena), rglucchi@ub.edu (R.G. Lucchi), oromero@ugr.es (O. Romero), amballegeer@usal.es (A.M. Ballegeer), jhonjairo@ugr.es (J.J. Gonzalez), dharwood1@unl.edu (D.M. Harwood).
}

\section{Introduction}

During the Pliocene Epoch, between 5 and 3 million years (Ma), the Earth experienced higher global surface temperatures than today (about $3^{\circ} \mathrm{C}$ ) (Sloan et al., 1996; Dowsett et al., 1996; Haywood et al., 2000 ) and higher atmospheric $\mathrm{CO}_{2}$ concentrations than pre-industrial 
times (Raymo et al., 1996). Warming during the early Pliocene, culminating in the mid-Pliocene Climatic Optimum at about $3 \mathrm{Ma}$ is suggested by the marine oxygen isotopic record obtained in low and high-latitude regions (e.g., Hodell and Venz, 1992; Kennett and Hodell, 1995; Shackleton et al., 1995; Zachos et al., 2001; Lisiecki and Raymo, 2005). Obliquity-driven oscillations (41 ka) in the $\delta^{18} \mathrm{O}$ signal of benthic foraminifera with amplitudes of up to $0.6 \%$, which dominate the Pliocene period, are capable of producing up to $30 \mathrm{~m}$ sealevel changes, but have been considered insufficient to give evidence for large scale Antarctic Ice Sheet deglaciation because uncertainties about the temperature changes in the deep-ocean (Shackleton et al., 1995). What is known about climate cycles and changes in ice-sheet volume during the early-middle Pliocene, however, is mostly derived from oxygen isotopic records from low and mid latitudes and from sea-level curves derived from low latitude passive continental margins. Proximal sediment records from the Antarctic margin are critical for deciphering of how past extreme periods of warmth and cold have affected sea-ice extent and Antarctic ice sheet volume and extent.

Results from drilling around the Antarctic margin during the past twenty years (e.g., Ocean Drilling Program-ODP Legs 178 in the Antarctic Peninsula and 119 and 188 in Prydz Bay; Cape Roberts and ANDRILL Programs in the Ross Sea) are providing valuable insights with regard to Antarctic Ice Sheet dynamics since its inception around $34 \mathrm{Ma}$. For the early to mid Pliocene these records show that the Southern Ocean has experienced higher temperatures (e.g., Bohaty and Harwood, 1998) and the Antarctic Ice Sheet has had a dynamic behavior (e.g., Webb and Harwood, 1991; Haywood et al., 2009). For example, ODP Leg 188 records obtained from the East Antarctic Prydz Bay continental shelf show evidence of repeated advance and retreat of the Lambert ice stream across the shelf in the Late Miocene and through the early Pliocene (Hambrey et al., 1991; Passchier et al., 2003; O'Brien et al., 2004). Juntilla et al. (2005) pointed out that fluctuations of smectite and chlorite within the clay mineral assemblage at Site 1165, on the Prydz Bay continental rise, during the middle Pliocene are consistent with a dynamic behaviour of the East Antarctic Ice Sheet (EAIS). Diatom assemblages recovered from Prydz Bay ODP sites 1166 and 1165, suggest low sea-ice concentrations through much of the Pliocene (Whitehead et al., 2005). In addition, silicoflagellate assemblages from Site 1165 pinpoint three intervals (4.6-4.8 Ma, 4.3-4.4 Ma, and 3.7 Ma) within the Pliocene, when Southern Ocean SSSTs were about $5{ }^{\circ} \mathrm{C}$ warmer than today (Whitehead and Bohaty, 2003). These data are consistent with isotopic estimates of warmer conditions than present during the Early Pliocene (Hodell and Venz, 1992). In addition, three periods of enhanced sediment supply originating from East Antarctica are recognized in the Late Miocene-Pliocene record of the East Kerguelen Ridge sediment drift, in the Indian Ocean to the north of Prydz Bay (Joseph et al., 2002). These pulses in sediment accumulation were interpreted as result of periodically warmer, less stable, ice sheet conditions during this time. On land, a warm Pliocene was inferred from an $8 \mathrm{~m}$-thick sequence of early Pliocene diatomaceous sands and silts exposed at Marine Plain in the Vestvold Hills (Pickard et al., 1988; Harwood et al., 2000; Whitehead et al., 2001). These deposits were interpreted to indicate that the ice margin was about $50 \mathrm{~km}$ further inland and no floating ice was covering the site.

Climate cycles have also been reported from West Antarctica. For example, in the western Antarctic Peninsula continental rise sediments recovered during ODP 178 confirmed that ice streams repeatedly advanced to the shelf break throughout the Pliocene (Barker et al., 2002; Hillenbrand and Ehrmann, 2005; Hepp et al., 2006). Based on sediment physical and geochemical properties from ODP Site 1095 in the Antarctic Peninsula, Hepp et al. (2006) propose a highly dynamic Antarctic Peninsula Ice Sheet (APIS) that is sensitive to Milankovitch eccentricity forcing during the early Pliocene. Periodic APIS reduction is suggested to explain the increased terrigenous flux to the continental rise corresponding to maximum amplitudes in the elements $\mathrm{Fe}$ and $\mathrm{K}$ (Hepp et al., 2006). The sedimentary section recovered from the Ross Sea by the ANDRILL program at Site AND-1B contains a well-dated record of cyclic variations in the ice sheet extent that are obliquity-paced (Naish et al., 2009). This record shows the West Antarctic Ice Sheet (WAIS) collapsed repeatedly in the Ross Sea embayment during interglacial periods characterized by high surface water productivity and minimal summer sea ice and air temperatures above freezing (Naish et al., 2009).

A strong decrease in sea-ice coverage at both, the Antarctic Peninsula and the East Antarctic margin starting at $5.3 \mathrm{Ma}$ and maintained during the early Pliocene is indicated by opal deposition (Grützner et al., 2005; Hillenbrand and Ehrmann, 2005; Hepp et al., 2006). A reduced extent of sea-ice in the Southern Ocean is indicated by an increase in biological productivity during the early Pliocene that is shown by the increase in opal deposition rates at East Antarctic ODP Site 1165 and West Antarctic Site 1095 (Hillenbrand and Fütterer, 2002; Grützner et al., 2005; Hillenbrand and Ehrmann, 2005).

Although evidence for a warm early Pliocene is constructed from different sites around Antarctica, little is known about the timing and extent of an East and West Antarctic Ice Sheet response to these warmer oceanographic conditions. These data are necessary to provide constraints to paleoclimate models that can help in forecasting future ice sheet behavior. In this paper we study and compare the sedimentary record from two Antarctic continental margins, one draining the APIS off the Pacific margin of the Antarctic Peninsula and the other draining the EAIS off Prydz Bay (Figs. 1 and 2). Our main objective is to characterize glacial and interglacial deposition at each margin, and to discriminate between regional and continent-wide early to middle Pliocene warm intervals that can cause sea-ice and continental ice sheet retreat. We conducted a high-resolution and multi-proxy (i.e., sediment facies and grain size, siliceous microfossils, biogenic opal, geochemical composition and clay mineralogy) analysis of sediments deposited between 4 and $3.5 \mathrm{Ma}$. Our results indicate open marine conditions with warm SSSTs, reduced sea ice and significant reduction of both the APIS and the EAIS during the early and middle warm periods of the Pliocene.

\section{Oceanographic setting}

The structure and circulation of water masses that overlie the western Antarctic Peninsula continental shelf are mainly controlled by the Antarctic Circumpolar Current (ACC), and especially by its narrowness at the proximity of the Drake Passage (Orsi et al., 1995). Two oceanographic fronts are located directly west of the Antarctic Peninsula, the Polar Front in the north and the southern boundary of the ACC in the south (Orsi et al., 1995). Sites 1095 and 1096 (Western Antarctic Peninsula) (Fig. 1), are covered by a thin surface layer of cold water of about 100-150 m water depth (Smith et al., 1999), the Antarctic Surface Water (AASW). This water mass has a temperature range from -1.8 to $1.0{ }^{\circ} \mathrm{C}$ and a salinity range from 33.0 to $33.7 \%$. Surface water currents on the shelf west of the Antarctic Peninsula show weak cyclonic gyres (Smith et al., 1999). In the Pacific sector of the Southern Ocean off the Antarctic Peninsula, the Circumpolar Deep Water (CDW) represents a mixture of North Atlantic Deep Water (NADW) and recirculated waters from the Indian and Pacific Oceans (Patterson and Whitworth, 1990). Thus, below the AASW there is a warmer and more saline water mass, the Circumpolar Deep Water (CDW) with temperatures around $1.6^{\circ} \mathrm{C}$, which protrudes onto the shelf (Hofmann et al., 1996; Smith et al., 1999). The CDW provides a consistent deep source of heat and salt and low oxygen water for the Western Antarctic Peninsula (Smith et al., 1999).

Site 1165 is located within or near a large cyclonic gyre, known as the Antarctic Divergence (AD), between $60^{\circ} \mathrm{E}$ and $100^{\circ} \mathrm{E}$ (Fig. 2). The $\mathrm{AD}$ results from the confluence of two currents: the ACC, which flows clock-wise around Antarctica, and the Polar Current (PC), which flows 


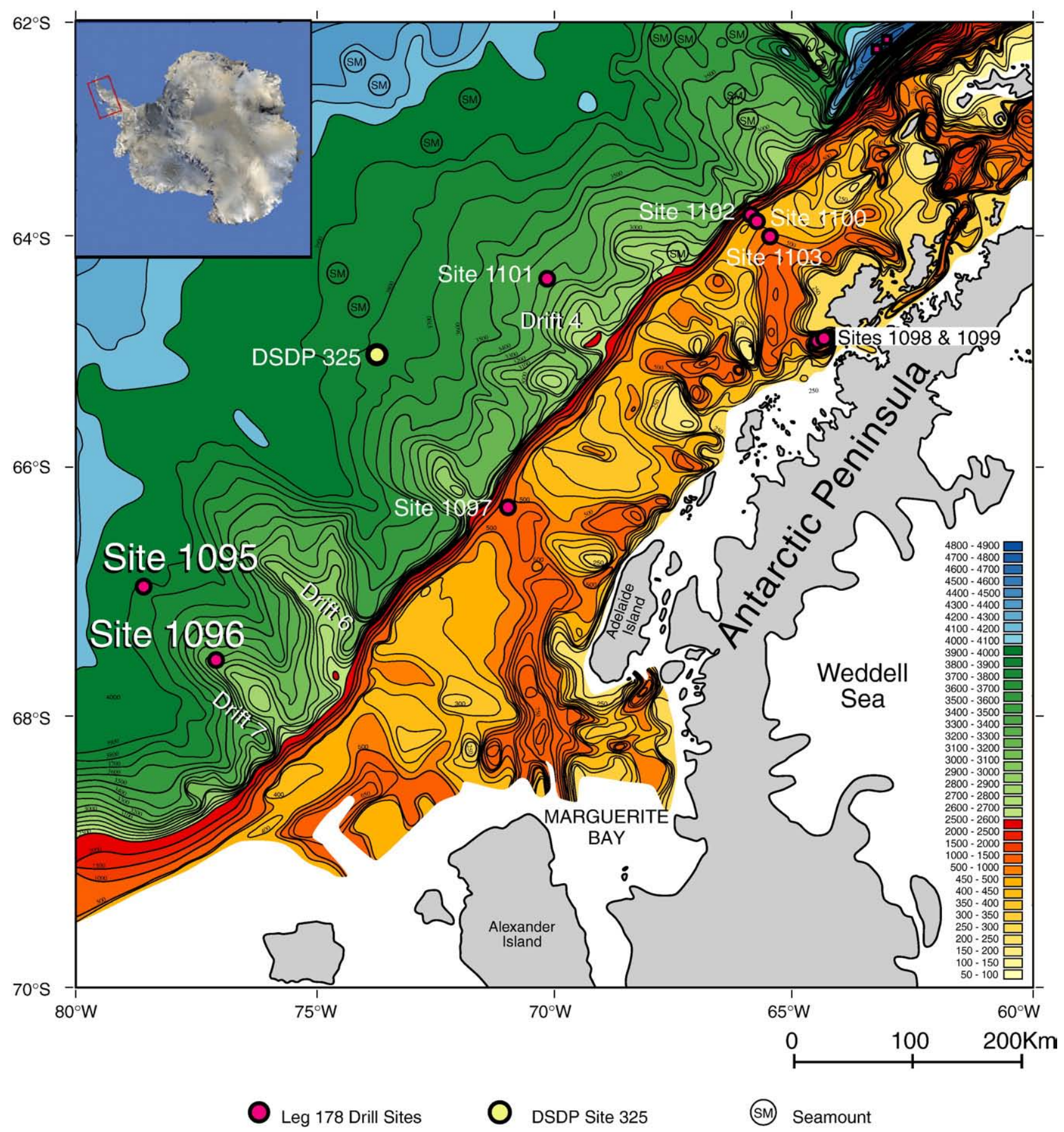

Fig. 1. Map showing the location of the ODP Sites 1095 and 1096 on the continental rise Drift 7 located on the Pacific margin of the Antarctic Peninsula.

westward (counter-clock-wise) close to the continent (Smith et al., 1984). Deep-water circulation is controlled by the influx of NADW, which transports warmer, saltier and nutrient-rich water from the North Atlantic as a consequence of the thermohaline circulation. When the NADW reaches the Southern Ocean it forms the CDW Water. The NADW, or the vertically mixed CDW, circulates onto the Prydz Bay shelf delivering nutrients and heat, which causes sea-ice to melt. In contrast to the western Antarctic Peninsula shelf, Prydz Bay is an area of saline bottom water formation, the Prydz Bay Bottom Water, a precursor of Antarctic Bottom Water (Nunes and Lennon, 1996).

At present, the climatic conditions at Site 1165 are characterized by cold SST; average SSST is $0.5^{\circ} \mathrm{C}$, average winter SST is $-1.8^{\circ} \mathrm{C}$ and mean annual SST is approximately $-0.5^{\circ} \mathrm{C}$ (Gordon and Molinelli, 1982). Winter sea-ice distribution shows a monthly median extent up to $59^{\circ} \mathrm{S}$, with sea-ice free conditions during summer (National Snow and Ice Data Center, NISDC).

\section{Materials and methods}

\subsection{Core locations}

The sediment cores analyzed for this study were collected by the Ocean Drilling Program (ODP) Leg 178 west of the Antarctic Peninsula (Sites 1095 and 1096) and Leg 188 in Prydz Bay (Site 1165, Figs. 1 and 2). Sites 1095 and 1096 were drilled on a hemipelagic sediment 


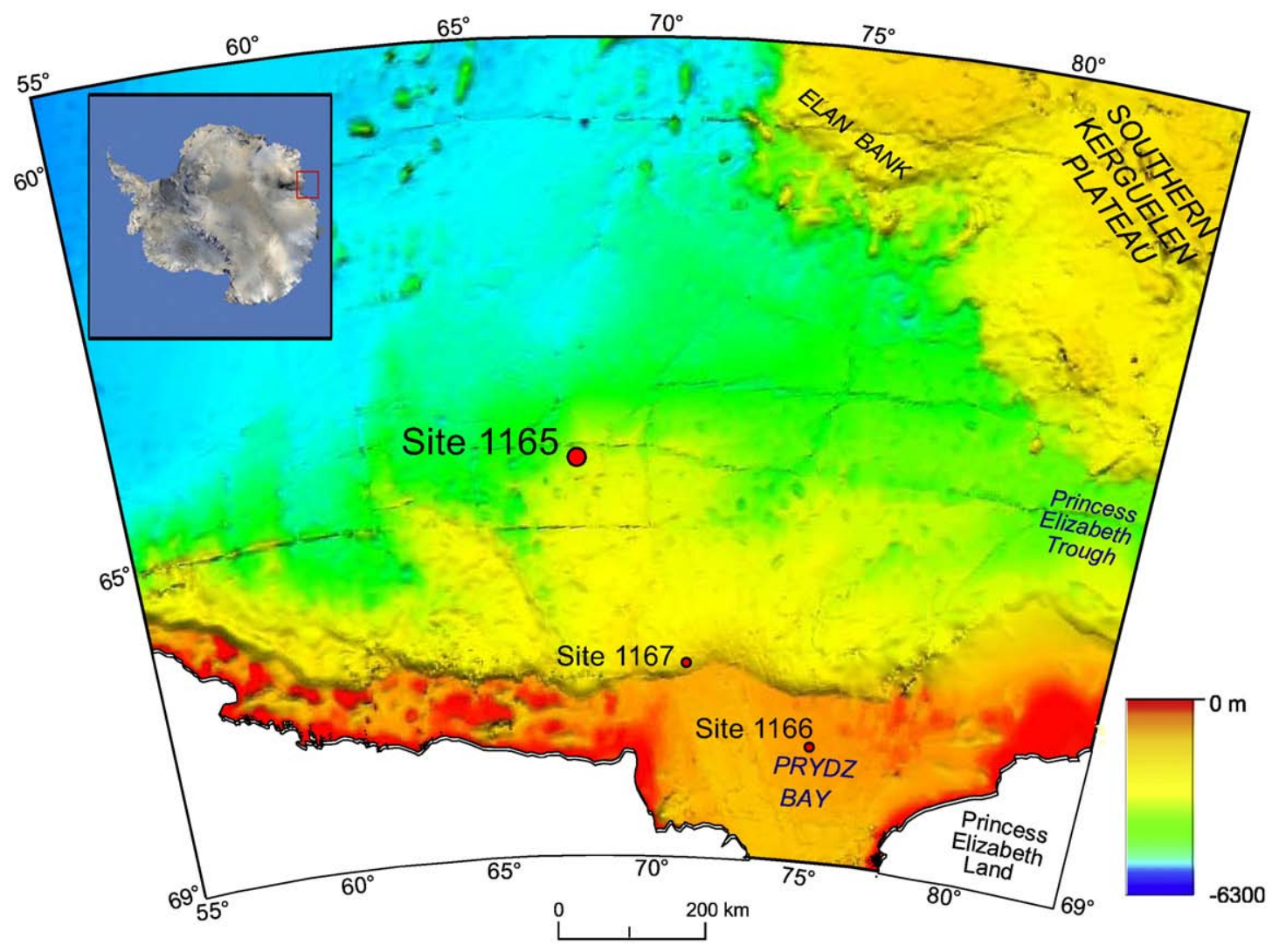

Fig. 2. Map showing the location of the ODP Site 1165 located on the continental rise Wild Drift off Prydz Bay.

drift (Drift 7, Rebesco et al., 1997) on the continental rise (Barker et al., 1999). These two sites were chosen in order to verify the proximal (1096) and distal (1095) sedimentary response to climatic variability affecting the APIS. Site 1095 is located at $66^{\circ} 59^{\prime} \mathrm{S}$ and $78^{\circ} 29^{\prime} \mathrm{W}$, at $3840 \mathrm{~m}$ water depth and it was cored with the advanced piston corer (APC) to 483.3 meters below sea floor (mbsf) (Barker et al., 1999). For this study we focused on a $10 \mathrm{~m}$ interval from 95.50 to $105.50 \mathrm{mbsf}$. Site 1096 is located at $67^{\circ} 34^{\prime} \mathrm{S}$ and $76^{\circ} 57^{\prime} \mathrm{W}$, at $3153 \mathrm{~m}$ water depth and was drilled using an Extended Core Barrel (XCB) coring tool (Barker et al., 1999). For our study we focused on a 7.5-meter interval from 401 to 408.5 mbsf.

Site 1165 was drilled into the Wild Drift located at $64^{\circ} 22.78^{\prime} \mathrm{S}$ and $67^{\circ} 13.14^{\prime} \mathrm{E}$, in $3537 \mathrm{~m}$ water depth on the continental rise offshore from Prydz Bay (O'Brien et al., 2001). This site was selected in order to obtain a proximal record of the response of the EAIS to glacial/ interglacial cycles that could be compared with the Leg 178 sites. Site 1165 was cored with the APC to $147.9 \mathrm{mbsf}$. This paper focuses on the $6 \mathrm{~m}$ long interval recovered from 34 to $40 \mathrm{mbsf}$.

\subsection{Core description and grain size analyses}

Sediment cores were re-described during a visit to the IODP-Bremen Core Repository (BCR). The visual description focused on sedimentary structures and texture, colour changes, with a preliminary compositional investigation through smear slides. In addition, selected intervals were X-radiographed at a medical facility in Bremen for detailed analyses on sedimentary facies and structures.

The textural characteristics of sediments were determined using both wet sieving at $63 \mu \mathrm{m}$ to separate the sand from mud (silt and clay) fractions, and the particle size analyser Sedigraph (SedigraphIII 5120 ) to analyze the fine fraction between 63 and $0.68 \mu \mathrm{m}$ with a resolution of $1 / 4$ phi and using a sodium metaphosphate dispersant solution of $0.05 \%$ to avoid particle flocculation. The sediment grain size was classified according to the scale of Freedman and Sanders (1978).

In addition, we used the Magnetic Susceptibility (MST) data sets produced during the ODP Legs (Barker et al., 1999; O'Brien et al., 2001), which are available from the ODP database (http://www-odp. tamu.edu/database/).

\subsection{Clay mineralogy}

Separation of the $<2 \mu \mathrm{m}$ fraction and preparation of the samples for $\mathrm{X}$-ray diffraction (XRD) were performed following the international recommendations of Kirsch (1991). X-ray diffractograms were recorded using a Philips PW 1800 diffractometer with $\mathrm{CuK} \alpha$ radiations $(50 \mathrm{kV}, 30 \mathrm{~mA})$ at angles ranging from $2^{\circ}$ to $64^{\circ} 2 \theta$ for bulksample diffractograms with untreated clay preparations and $2^{\circ}-30^{\circ} 2 \theta$ for glycolated clay-fraction samples. Xpowder software (Martin, 2004) was used to determine background levels, and calculate peak intensities and peak areas. The principal clay mineral groups were recognized by their basal spacing at $17 \AA$ (smectite), at $10 \AA$ (illite) and $7 \AA$ (kaolinite + chlorite). Peak areas have been measured in order to estimate semi-quantitative clay mineral content. Estimated semiquantitative analysis errors range from $5 \%$ to $10 \%$; although semiquantitative analysis aims to show changes or gradients in mineral abundances rather than absolute values. The integrated areas were multiplied by weighting factors (Biscaye, 1965) and normalized to $100 \%$. Weighting factors are 4 for illite, 2 for kaolinite + chlorite, and 1 for smectite (Biscaye, 1965).

\subsection{X-Ray Fluorescence}

Measurements of a total of 23 major and trace element were obtained with a Pioneer-Bruker X-Ray Fluorescence (XRF) spectrometer S4 at the Instituto Andaluz de Ciencias de la Tierra (CSIC) in 
Granada, equipped with a Rh tube $(60 \mathrm{kV}, 150 \mathrm{~mA})$ using internal standards. The samples were prepared in a Vulcan $4 \mathrm{M}$ fusion machine and the analyses performed using a standard-less spectrum sweep with the Spectraplus software.

\subsection{Siliceous microfossils}

Siliceous microfossil studies were carried out on samples spaced at 10 or $20 \mathrm{~cm}$ intervals. For diatom analyses, samples were prepared according to the standard randomly distributed microfossils method. Qualitative and quantitative analyses were done at 1000 magnification using a Leica DMLB with phase-contrast illumination. Counts were carried out on permanent slides of acid-cleaned material (Permount mounting medium). Schrader and Gersonde (1978) recommendations were followed for the counting of microfossil valves. Depending on the diatom abundance, several traverses across each cover slip were examined. A minimum of 350 valves were counted for each sample, when possible.

The silicoflagellate genus Dictyocha and Distephanus were counted in order to establish a warm/cold ratio (W/C R) as a function of their abundance. Bohaty and Harwood (1998) and Whitehead and Bohaty (2003) previously have defined warm/cold ratio and silicoflagellate index respectively. These ratios reflect the relative abundance of Dictyocha and allowed the reconstruction of SSSTs and thus the identification of warmer Pliocene periods in the Southern Ocean. In this paper we have defined a modified $\mathrm{W} / \mathrm{C}$ R by using silicoflagellates total abundance in the following normalized formula: Dictyocha (skeletons/g of dry sediment)/[Dictyocha + Distephanus (skeletons/g of dry sediment)]. Values oscillate between 0 and 1 with the highest values indicating warmer temperatures whereas values close to 0 indicate colder temperatures.

\subsection{Biogenic opal}

Biogenic opal was measured on samples from the same depths as the diatom samples. Samples were dried and ground in an agate mortar. Opal was determined with a sequential leaching technique proposed by De Master (1981) and modified by Müller and Schneider (1993).

\subsection{Age model}

The age model for the studied sediment core sections was established on the basis of the magnetostratigraphic datums constrain by marine diatom and radiolarian biostratigraphic control, in sediments recovered by Legs 178 and 188 (Barker et al., 1999; O'Brien et al., 2001; Warnke et al., 2004). The age of the paleomagnetic reversals used for both expeditions was based on different time scales: The time scale of Berggren et al. (1995) was used for Sites 1095 and 1096 during Leg 178 (Iwai et al., 2002) and the time scale of Cande and Kent (1995) was used for Site 1165 during Leg 188 (Warnke et al., 2004). For this work we used for all the age models the astronomical tuned timescale of Lourens et al. (1996) assigning corresponding age to the paleomagnetic reversals (Fig. 3). Using the chronology established by paleomagnetic reversals and the sediment thickness between them, sedimentation rates were calculated for the various early to middle Pliocene core intervals (Fig. 3). At Site 1095 the average sedimentation rate is $4.40 \mathrm{~cm} / \mathrm{ka}$. The Pliocene interval at Site 1096 was deposited at an average sedimentation rate of $15.88 \mathrm{~cm} / \mathrm{ka}$; changing from $14.16 \mathrm{~cm} / \mathrm{ka}$ during C2An3n to $17.60 \mathrm{~cm} / \mathrm{ka}$ during C2Ar. At Site 1165 the average middle Pliocene sedimentation rate is $1.53 \mathrm{~cm} / \mathrm{ka}$. During $\mathrm{C} 2 \mathrm{An} 3 \mathrm{n}$ the sedimentation rate is $2.12 \mathrm{~cm} / \mathrm{ka}$, and during $\mathrm{C} 2 \mathrm{Ar}$ it is $0.94 \mathrm{~cm} / \mathrm{ka}$. Based on the age model and sedimentation rates, sediment samples were dated by linear interpolation between polarity chron boundaries. The studied interval spans the time period 3.7-3.5 Ma at Site 1095, 3.5-3.6 Ma at Site 1096, and 4-3.5 Ma at Site 1165.

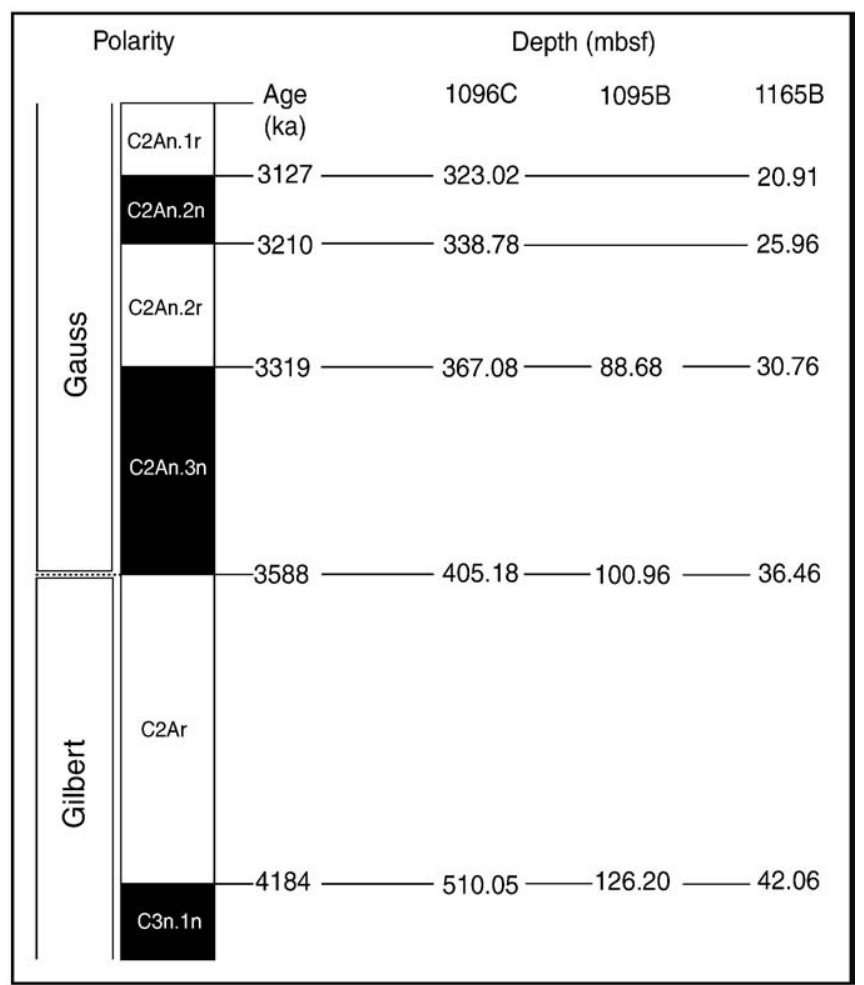

Fig. 3. Age control for the studied sediment sections based on paleomagnetic polarity changes. Corresponding depths below sea floor (mbsf) at each of the studied ODP Sites on the Antarctic Peninsula (Sites 1095 and 1096) and the Prydz Bay (Site 1165) rise are shown. All studied core sections include the Gilbert-Gauss reversal at 3.588 Ma. Agedepth fix points are used to calculate sedimentation rates for these sections, which allow the interpolation of ages within the studied section.

\section{Results}

Results of the analytical work from this study are presented plotted against depth and ages in Figs. 4-6.

\subsection{Sediment facies and textural characteristics}

Four main sedimentary facies were identified by lithological descriptions and X-radiographs (Fig. 4):

Facies 1, laminated mud with silt layers: finely laminated silty clays with silt layers and silt-rich horizons. Silt layers up to $1 \mathrm{~cm}$-thick have sharp-irregular boundaries and laterally discontinuous thicknesses. Sandy silt horizons (mm-thick) are often laterally discontinuous. The preliminary compositional investigation revealed terrigenous sediments nearly barren of microfossils. This facies was recovered at Site 1095 from 95.52 to $96.20 \mathrm{mbsf}$ and at the base of the studied interval from 103.79 to 105.29 mbsf. Facies 2, structureless mud: structureless fine-grained sediment almost barren of microfossils. This facies was mainly observed at Site 1096.

Facies 3, mud with silt patches: fine-grained sediment with silt patches. These sediments are almost barren of microfossils like Facies 2, but contain randomly distributed silt fraction patches. This facies occurs only at Site 1095.

Facies 4, bioturbated mud: fine-grained bioturbated sediment with dispersed and/or layered IRD. The preliminary compositional investigation revealed diatom-bearing mud. This facies characterizes Sites 1165, but also occurs at Site1095, and in the upper part of Site 1096 (Fig. 4). Two thick IRD intervals (up to 10 and $20 \mathrm{~cm}$ thick) 
Pacific Margin of

Antarctic Peninsula

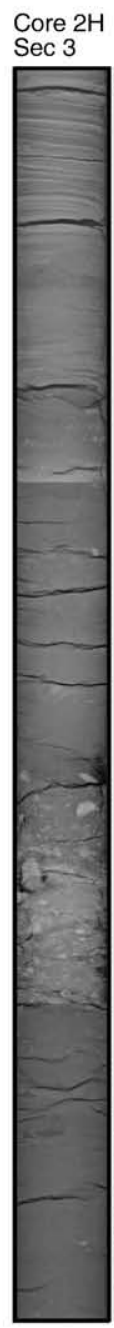

Lithology
Leg 178

Hole 1096C
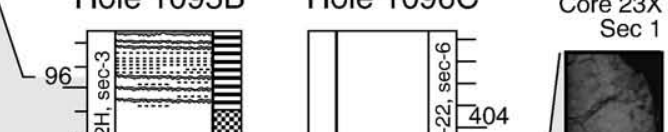

-

-

它

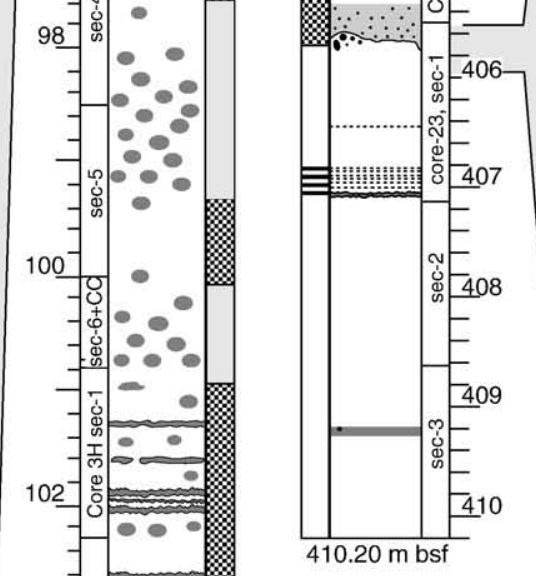

$410.20 \mathrm{~m}$ bsf

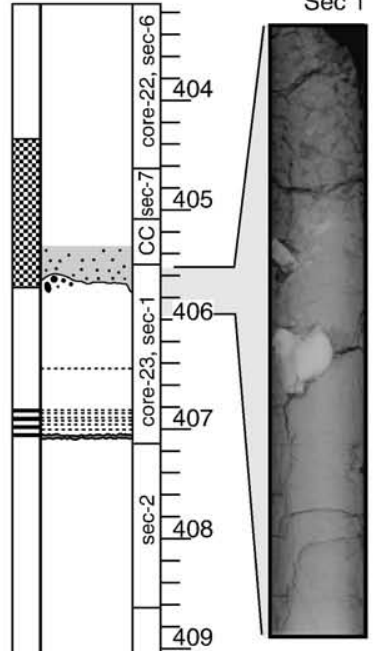

Prydz Bay

East Antarctica

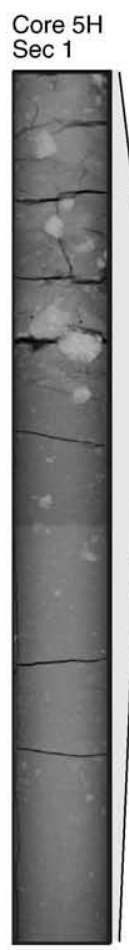

Core $5 \mathrm{H}$ $\operatorname{Sec} 3$

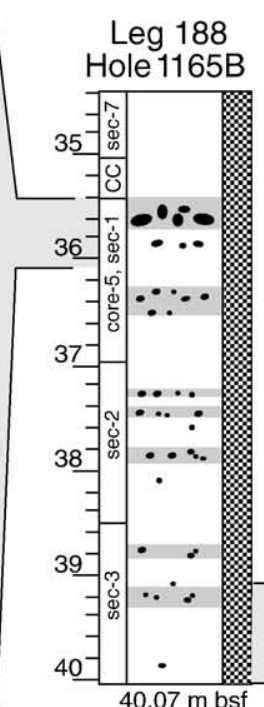

\section{Sediment facies}

sandy/silty layers, horizons, patches pebbles irregular boundaries

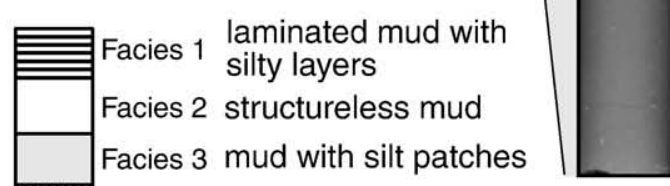

Facies 4 bioturbated mud with sparse IRD
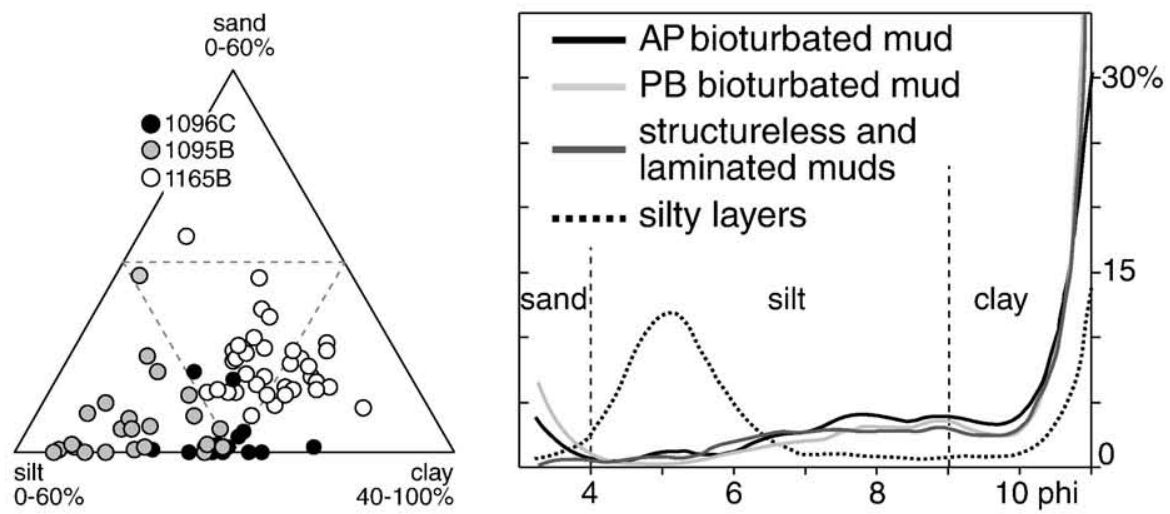

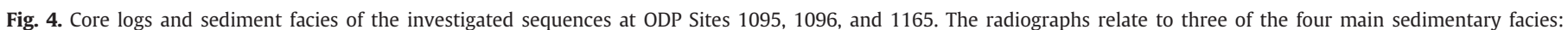

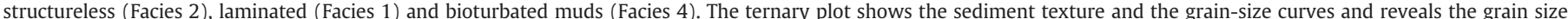

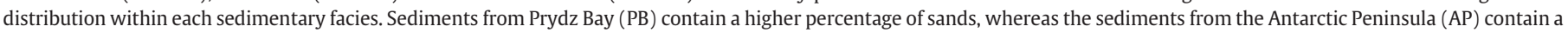
higher percentage of silts. Some silt layers can contain up to $80 \%$ of silt (out of the triangle plot).

were found at the top of the sedimentary sequences studied at Sites 1096 and 1165.

The textural analyses of all cores revealed the presence of prevailing fine-grained sediment with the clay fraction often exceeding $50 \%$.
Sediments recovered from the Wild Drift are coarser than those from the Antarctic Peninsula margin, with a higher percentage of sand but a lower content of silt (Fig. 4).

Facies 1 and 2 from Drift 7 contain the finest-grained sediment with less than $1 \%$ sand and prevailing fine-grained silt and clay 
(clay $>50 \%$, silt $\cong 40 \%$ average). Facies 4 from the Antarctic Peninsula sites contains 3\% (average) sand and a higher percentage of coarse and very-coarse silt than Facies 2 with an average silt content of $47 \%$ and a clay content below the $50 \%$.

Facies 4 from Prydz Bay contains a high percentage of sand (9\% average), a low content of silt (30\% average) with fine-grained silt prevailing, and a high percentage of clay (over $50 \%$ ).

The grain size distribution within the silt layers of Facies 1 at Site 1095 clearly differ from the other sediment types because of the high silt content (up to 80\%). The IRD layers of Facies 4 in Drift 7 contain gravel and occasionally $\mathrm{cm}$-thick pebbles within a sandy-clay matrix with a low percentage of silt (30\% average). They have a grain-size spectra very similar to those of the IRD layers in Facies 4 from Prydz Bay.

\subsection{Clay mineral assemblages and provenance}

The clay mineral assemblage from the Antarctic Peninsula region (Fig. 5) is dominated by illite ( $40-58 \%$ at Site 1095 and $28-45 \%$ at Site 1096) and chlorite-kaolinite (33-55\% at Site 1095 and 50-70\% at Site 1096). Smectite contents vary from 5 to $10 \%$ and from 3 to $7 \%$ in the samples from Sites 1095 and 1096, respectively. At Site 1095 chloritekaolinite concentrations generally increase from 102 mbsf up-section.

The clay mineral assemblage in the samples from Prydz Bay is dominated by illite (50-70\%) with lower contents of chloritekaolinite (25-38\%), and smectite (5-12\%). Possible source rocks in the hinterland of Prydz Bay belong to the Pagodroma Group, which comprises the: 1) middle Miocene Fisher Bench Formation and older Mount Johnston Formation that contain a dominance of illite and chlorite assemblages (Ehrmann et al., 2003); 2) the middle-late Miocene Battye Glacier Formation that have a dominance of smectite and kaolinite, and 3) the Pliocene-Pleistocene Bardin Bluffs Formation, which has the highest kaolinite content in absence of smectite.

\subsection{Geochemistry}

Down core contents of Aluminum (Al), Iron (Fe), Titanium (Ti), and Barium (Ba) are shown in Figs. 5 and 6 as indicative of terrigenous input ( $\mathrm{Al}, \mathrm{Fe}, \mathrm{Ti}$ ) or biogenic component abundance ( $\mathrm{Ba} / \mathrm{Al}$ ratio). $\mathrm{Fe}$ and $\mathrm{Ba}$ are presented normalized with the Aluminium that is a relatively stable element (not affected by alteration).

Sediment samples from both West and East Antarctic locations have high Fe and Al contents (Figs. 5 and 6). In samples from Site 1095 , Fe values range from 5 to $8 \%$ and Al values from 6 to $8 \%$. At Site $1095 \mathrm{Fe}$ and $\mathrm{Al}$ contents start to increase at $102 \mathrm{mbsf}$ and $101.2 \mathrm{mbsf}$ and up-section, respectively. Site 1096 samples exhibit Fe and Al values that range from 4 to $5 \%$ and 7 to $7.7 \%$, respectively. At Site 1096 a marked decreasing trend up-section of Fe and Al values is seen starting at 405 mbsf. In samples from Site 1165, Fe values range from 3 to $4.7 \%$ and $\mathrm{Al}$ values range from 5 to $6.5 \%$. At Site 1165 , the increasing trend up-section in Fe and Al values starts at 37.7 mbsf (Fig. 6).

Titanium is a trace element indicating terrigenous input, and its content is positively correlated with that of Aluminium at all three sites (Figs. 5 and 6). The $\mathrm{Al}$ and Ti contents usually are coherent with the Fe content except for the upper part of Site 1095 above $101 \mathrm{mbsf}$.

Barium is found in trace amounts at all studied sites. The concentrations of Ba are generally lower in the samples from the Antarctic Peninsula rise with values that vary from 0.05 to $0.15 \%$ (Fig. 5). In samples from the East Antarctic margin, the values are higher and range from 0.1 to $0.5 \%$ (Fig. 6 ). The $\mathrm{Ba} / \mathrm{Al}$ ratio is used as an indicator for biogenic Ba, which is a proxy for biological productivity (cf. Pudsey, 2000; Hillenbrand and Fütterer, 2002). High-percentage of Ba correlates with the normalized $\mathrm{Ba} / \mathrm{Al}$ record, and with the biogenic components abundance.

\subsection{Siliceous microfossils}

Siliceous microfossil assemblages consist of marine diatoms and silicoflagellates. The diatom assemblage analyzed in this study comprises more than 38 taxa with Fragilariopsis barronii being the most abundant species (up to $54 \%$ of the diatom assemblage) (Figs. 5 and 6). Other significant taxa are Fragilariopsis interfrigidaria, Rouxia antarctica, Thalassiosira inura, T. torokina, T. oestrupii, T. tumida, Eucampia antarctica and Stellarima microtrias. Silicofagellate assemblages consist of two genera, Distephanus and Dictyocha.

Total diatom valve abundance conducted in samples from Site 1095 ranges from $4.3 \times 10^{5}$ to $8.2 \times 10^{6}$ valves/g (average value is $1.97 \times 10^{6}$ valves $/ g$ ) (Fig. 5). Diatom abundance curves show two main pronounced maxima: from 102 to $101 \mathrm{mbsf}$ with up to $6.02 \times 10^{6}$ valves $/ \mathrm{g}$, and from 97.2 to $96.0 \mathrm{mbsf}$ with up to $8.16 \times 10^{6}$ valves $/ \mathrm{g}$. A secondary maxima with values around $1.63 \times 10^{6}$ valves/g is observed at 99.7 mbsf. The most abundant taxon, $F$. barronii represents up to $54 \%$ of the diatom assemblage. This species shows three maxima roughly corresponding with peaks in total diatom abundance: i) from 104.82 to 101.4 mbsf $F$. barronii exhibits average values of $30 \%$ of the assemblage, ii) from 100.02 to $99.40 \mathrm{mbsf}$ the species has values of $25 \%$ of the diatom assemblage, and iii) from 97.52 to $96.14 \mathrm{mbsf}$, the group shows its highest values, with an average of 54\% (Fig. 5).

Total abundance of silicoflagellates at Site 1095 is low, only $1.4 \times 10^{5}$ skeletons/g is the highest concentration. The silicoflagellate assemblage is best represented in the upper part of the core from 97.10 to 96.02 mbsf. When present, Distephanus is the dominant taxon, and accounts for more than $80 \%$ of the abundance. Nevertheless, some specimens of Dictyocha have been observed at different depth intervals (96.14, 96.88, 97.83 and $103.20 \mathrm{mbsf}$ ) and the W/C R may indicate episodes of warmer sea-surface temperatures (Fig. 5).

Siliceous microfossil analyses conducted in Site 1096 materials show a scarce and poorly preserved diatom assemblage. Diatom abundance is one order of magnitude lower than at Site 1095. The analyzed section can be divided into: i) a lower part, from the base to $405.9 \mathrm{mbsf}$, with a low diatom abundance $\left(3.78 \times 10^{4}\right.$ valves $\left./ \mathrm{g}\right)$ and, ii) an upper part, from 405.9 to $404.64 \mathrm{mbsf}$ with $1.33 \times 10^{5}$ valves $/ \mathrm{g}$ and a maximum of $2.5 \times 10^{6}$ valves/g at 405.56 mbsf (Fig. 5). F. barronii has an average value of $9.3 \times 10^{3}$ valves/g and makes up an average of $7 \%$ of the assemblage. In the section from 405.7 to $405.32 \mathrm{mbsf}$, however, F. barronii averages $14 \%$ of the diatom assemblage and has a maximum of $26 \%$ at 405.56 mbsf. No silicofallelates were observed at Site 1096.

Total diatom valve abundance in samples from Site 1165 ranges from $1.38 \times 10^{6}$ to $1.25 \times 10^{7}$ valves/g (average $5.83 \times 10^{6}$ valves $/ g$ ), which is one order of magnitude higher than at Site 1095. F. barronii, the most abundant species, makes up $5.6 \times 10^{4}$ to $4.6 \times 10^{6}$ valves/g (average value of $1.3 \times 10^{6}$ valves/g) (Fig. 6). This taxon follows the same pattern as the total diatom abundance: lower values below $7.46 \times 10^{5}$ valves/g and $F$. barronii contents of $6.1 \%$ are recorded from the base to 38.05 mbsf. From 38.05 mbsf to the section top, absolute diatom and $F$. barronii abundance increases from $<10 \%$ to $15-40 \%$. This interval is characterized by well-defined abundance fluctuations with amplitudes accounting for concentration changes of about $10 \%$. A marked minimum in $F$. barronii abundance down to $6 \%$ can be observed between 36.9 and $36.5 \mathrm{mbsf}$, and a secondary minimum can be observed between 35.59 and 35.15 mbsf (Fig. 6).

Total abundance of silicoflagellates at Site 1165 is higher than for Site 1095 with an average content of $1.35 \times 10^{5}$ skeletons/g and a

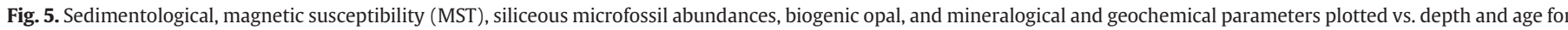

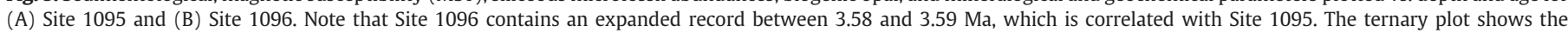
differences in the clay mineralogy record from Site 1095 between interglacial periods (enhanced smectite) and glacial periods (enhanced chlorite) (Rebesco et al., 2007). 


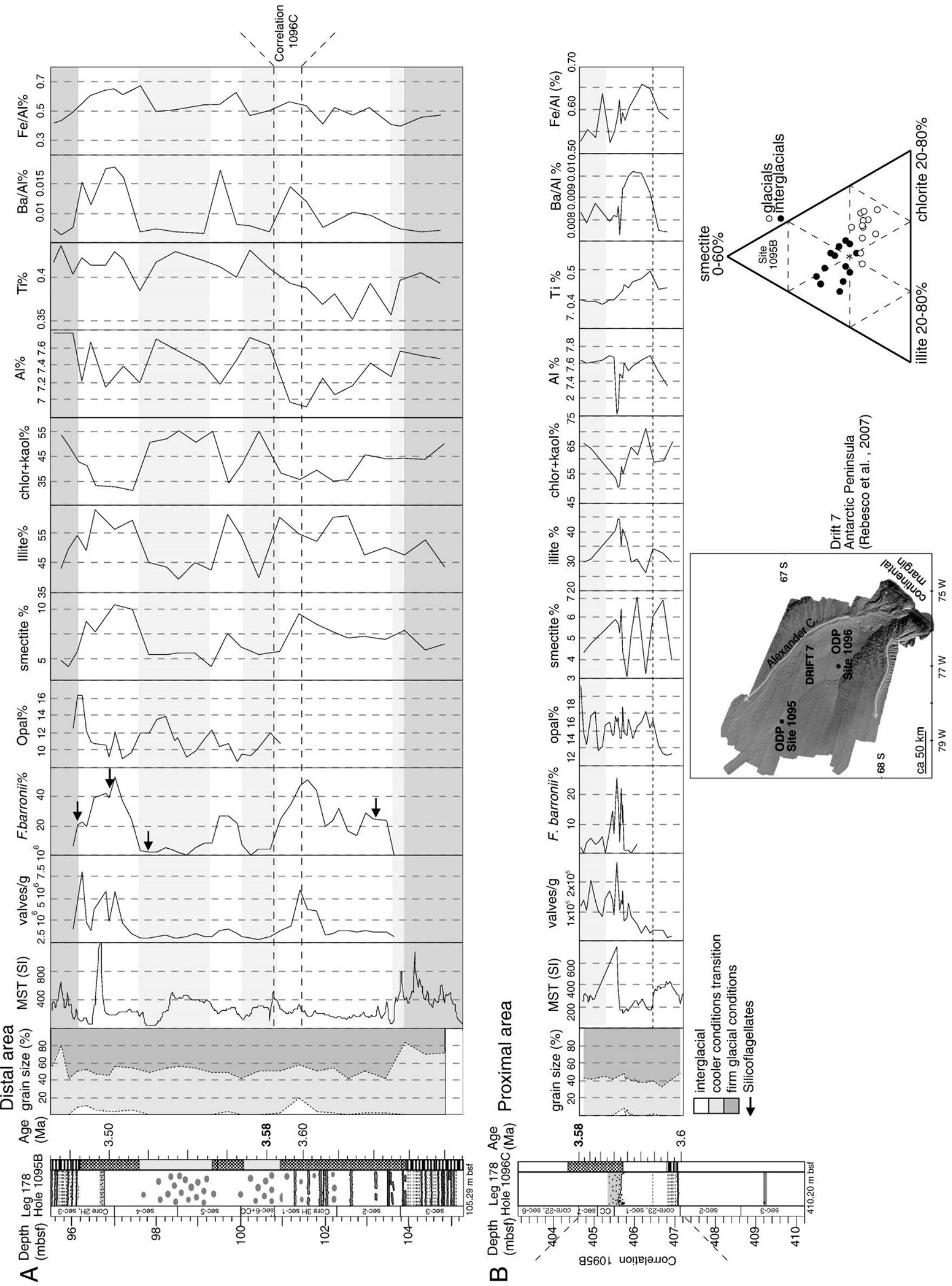


maximum up to 4.4 skeletons/g. Silicoflagellates are present throughout the studied section, but from $35.64 \mathrm{mbsf}$ they become more abundant towards the top (Fig. 6). Distephanus is the dominant taxon, and makes up more than $88 \%$ of the abundance. W/C R and Dictyocha relative abundance follow the same pattern. Dictyocha has an average content of $9 \%$ and it is significantly more abundant at three intervals, coinciding with the established W/C R: 37.62 to 37.30 mbsf (average abundance of $59.40 \%$ with maximum values up to $85 \%$, W/C R up to 0.75 ); 35.92 to 35.64 mbsf (average abundance of $16 \%, W / C$ R up to 0.25 ) and 35.17 to $34.95 \mathrm{mbsf}$ (average abundance of $8.3 \%, \mathrm{~W} / \mathrm{C} \mathrm{R}$ up to 0.10 ). Several smaller maxima can be observed at the lower part of the section (Fig. 6). The Dictyocha interval between 37.62 and 37.30 mbsf includes the $60 \%$ values at 37.60 mbsf previously reported by Whitehead and Bohaty (2003) from Site 1165 and interpreted to indicate a SSST of about $5.6^{\circ} \mathrm{C}$ above present level.

\subsection{Biogenic opal}

The biogenic opal content west of the Antarctic Peninsula varies between 9 to $15 \mathrm{wt} . \%$ in samples from Site 1095, and 11 to $19 \mathrm{wt} . \%$ in samples from Site 1096 (Fig. 5). In samples from Prydz Bay (Site 1165) the biogenic opal content varies from 15 to $30 \mathrm{wt}$.\% (Fig. 6).

The interval between 38.5 and $36 \mathrm{mbsf}$ at Site 1165, exhibits enhanced biogenic opal concentrations (up to 20-27\%). Similar to the $F$. barronii record, the opal concentration in this interval is characterized by pronounced variations with amplitudes of about $10 \%$.

\section{Discussion}

\subsection{Climate proxies}

In areas dominated by hemipelagic sedimentation, biogenic abundance may be controlled by both the variance in terrigenous supply and biogenic production. The down-core coeval increase in the Ba record, the $F$. barronii and total diatom abundance, and the biogenic opal (Figs. 5 and 6), suggests that biogenic processes are controlling the changes. According to Zielinski and Gersonde (2002) and Cortese and Gersonde (2008), F. barronii is assumed to be the evolutive precursor of $F$. kerguelensis, and speculate that both species lived under similar SSST conditions. In this sense, F. kerguelensis shows a dwelling preference of open-ocean conditions with summers free of sea-ice and SSST between 1 and $12{ }^{\circ} \mathrm{C}$ (Crosta et al., 2005) corresponding to the modern Antarctic Zone and the Polar Frontal Zone. Pleistocene SSST reconstruction based on diatom transfer function indicates a relationship between increased $F$. kerguelensis abundance and SST during interglacials (Zielinski and Gersonde, 1998). Moreover, Cortese and Gersonde (2008) affirm that F. barronii during the warm middle Pliocene, as well as F. kerguelensis during the middle-late Pleistocene, are the main carriers of organic matter and nutrients to the deep-ocean, these species were/are the main contributors to the production of the biogenic opal and export productivity to the Southern Ocean.

Based on the close positive correspondence between the peaks in silicoflagellate W/C R at Sites 1095 and 1165 and the indicators for higher biogenic productivity (Figs. 5 and 6) we interpret these events to record high biogenic productivity during interglacial warm climate conditions. The observed enhancement of smectite corresponding with interglacial periods in sediments from Site 1095 (Fig. 5) had been interpreted in previous studies to result from bottom-current transport of smectite along the continental rise, from its source on the continental shelf northwest of the Antarctic Peninsula, during interglacial climate periods (Hillenbrand and Ehrmann, 2001; Lucchi et al., 2002; Hillenbrand and Ehrmann, 2005; Hepp et al., 2006).

Down-core changes in the distribution of the two detrital elements $\mathrm{Al}$ and $\mathrm{Ti}$ indicate variability in the terrigenous supply to our sites. Higher supply of terrigenous detritus between the warm intervals, could be caused by advances of glaciers/ice-sheets during cold glacial conditions across the shelf or through proglacial meltwater plumes and sediment gravity flows during the deglaciation period. The laminated sedimentary facies that characterize the intervals of higher terrigenous supply at Site 1095 and the enrichment in chlorite in Drift 7 sediments, previously have been interpreted to occur under glacial conditions (e.g., Pudsey, 2000; Hillenbrand and Ehrmann, 2001; Lucchi et al., 2002; Hepp et al., 2006).

\subsection{Early Pliocene interglacial record: biogenic productivity and sedimentary processes}

\subsubsection{Antarctic Peninsula}

Sediments from Site 1095 record three main intervals of enhanced biogenic productivity during interglacial climates that are identified by a positive correlation between peaks in F. barronii abundance, presence of silicoflagellates and maxima of biogenic opal and biogenic Ba content. These intervals are located between 104.8-101.4, 10099.4, and 97.8-96 mbsf (Fig. 5). Peaks of productivity correlate positively with enhanced illite and smectite contents, and correlate inversely with values of Al, Ti, Fe, MST, and chlorite-kaolinite (Fig. 5). Based on our age model, these depth intervals of enhanced biogenic productivity occur between 3.7-3.6 Ma and 3.5 Ma, respectively. Within these time intervals, the highest productivity peaks are recorded at 103.5, 102.5, 101.6, and 99.7 mbsf (3.6 Ma), and 98.2, 97, 96.2 and $94.1 \mathrm{mbsf}$ (3.5 Ma) (Fig. 5). Siliceous microfossil assemblages suggest that during these interglacial periods there was low or no sea-ice above Site 1095 because sea-ice related taxa were not recorded in the diatom assemblage. At Site 1096, interglacial conditions are indicated between 406 and 405 mbsf by peaks in F. barronii and biogenic Ba coinciding with the magnetic polarity reversal (Gilbert-Gauss) at 3.58 Ma (Fig. 5).

Interglacial sediment facies at Sites 1095 and 1096 consist of bioturbated diatom-bearing sandy mud with both sparse and layered IRD (Facies 4). Thick IRD layers and/or coarser grained sediments correspond to maximum peaks of bio-productivity (Figs. 4 and 5). In sediments deposited by the Laurentian Ice Sheet, well-dated major instabilities of the ice sheet are manifested as beds of ice rafted detritus that is deposited during deglaciation (Skene and Piper, 2003). The marine sediment facies located off the Antarctic Peninsula, with both sparse and layered ice-rafted detritus, suggest a significant increase of the APIS calving during the interglacial intervals with open water conditions and no sea-ice cover above these offshore sites.

The marine clay mineral assemblage off the Antarctic Peninsula during interglacial intervals is dominated by illite ( $>40 \%$ ) with higher values of smectite and minor values of chlorite-kaolinite with respect to glacial intervals (Fig. 5). According to Lucchi et al. (2002) and Hillenbrand et al. (2008), the illite in this area is delivered through sub-glacial meltwater plumes, whereas smectite-rich sediments are transported by bottom contour currents coming from the South Shetland Islands (the "smectite province" of Hillenbrand and Ehrmann, 2001 located north of $64^{\circ} \mathrm{S}$ ). The lack of lamination associated to contour currents is explained by high bioturbation of sediments and/or low flow strength. The higher values of both illite and smectite during interglacials is related to a minor input of chlorite-kaolinite rather than a higher strength or efficiency of both contour currents and turbid meltwater plumes. The chlorite derives from the ablation of the crystalline basement and it is delivered into the area by down-slope mass transport largely occurring during glacials when the grounded-ice reached the shelf edge (Hepp et al., 2006).

At Site 1095, three warm episodes were detected based on sediment facies (i.e., 102.8-101 mbsf, 100-99.4 mbsf, and 97.6-96.2 mbsf) (Fig. 4); these episodes coincide closely with the high-productivity and coarser grained intervals. At Site 1096 only one minor warm episode was detected (407.2-405.6-404.4 mbsf), in which coarser-grained 


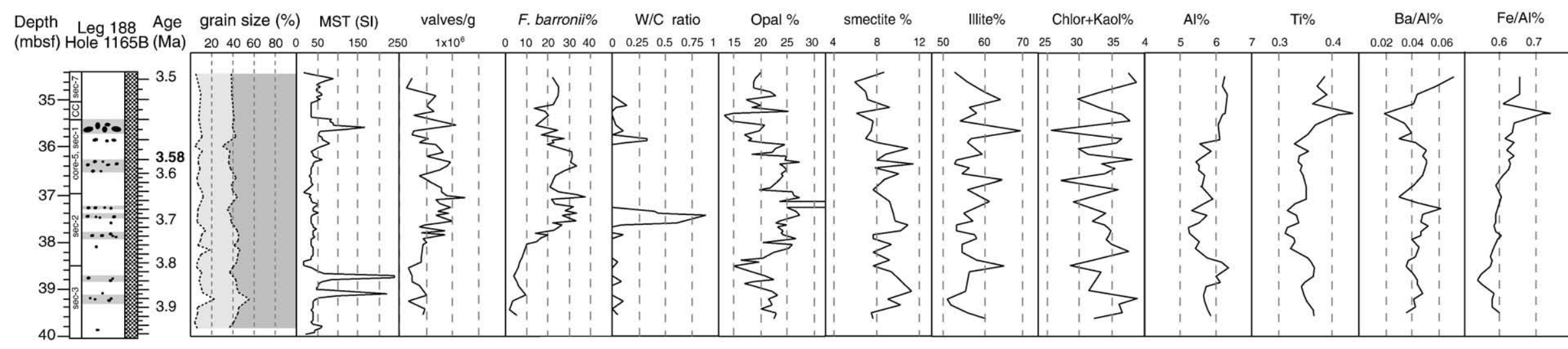

Fig. 6. Sedimentological, magnetic susceptibility (MST), siliceous microfossil abundances, biogenic opal, and mineralogical and geochemical parameters plotted vs. depth and age for Site 1165 s. 
sediments are characterized by moderate productivity and are confined by almost barren glacial sediments nearly barren of microfossils.

\subsubsection{Prydz Bay}

Prydz Bay Site 1165 records two main intervals of enhanced biogenic productivity that are marked by increased abundance of F. barronii, which roughly coincide with increased biogenic Ba content between 37.8-36.8 mbsf and 36.6-34.8 mbsf (Fig. 6). Based in our age model these two higher biogenic productivity intervals took place between 3.7 and 3.5 Ma, respectively. Diatom assemblages indicate that open water marine conditions with no sea-ice characterize these intervals of warmth. This is in agreement with previously published data by Whitehead et al. (2005) who applied the Eucampia antarctica Index and observed that during our studied interval the area experienced a significant reduction of winter sea-ice concentration (60\% less than today). Individual peaks of high biogenic productivity are recorded at $39.15 \mathrm{mbsf}$ (3.9 Ma), 37.7, 37.35 and $37 \mathrm{mbsf}$ (3.7 Ma), 36.3 and $36 \mathrm{mbsf}$ (3.6 Ma), and 35.23 and $34.5 \mathrm{mbsf}$ (3.5 Ma). The peaks at $36 \mathrm{mbsf}$ coincide with the magnetic polarity reversal (Gilbert-Gauss) at $3.58 \mathrm{Ma}$.

The silicoflagellate W/C R record from Site 1165 shows three main intervals of warmth within the studied section. Based in our age model, the lower warm interval occurs at $3.7 \mathrm{Ma}$ (37.62 and $37.34 \mathrm{mbsf})$. This interval includes the $60 \%$ Dictyocha values at 37.60 mbsf reported by Whitehead and Bohaty (2003) from Site 1165 and interpreted to indicate a mean annual SSST of about $5.6^{\circ} \mathrm{C}$ above modern level. Our data reveals W/C R up to 0.75 (Dictyocha average abundance values of $59.4 \%$, up to $85 \%$ ) within this interval, which indicate SSSTs even higher than those postulated by the former authors. A younger interval in W/C R is recorded at 3.6-3.5 Ma (36 and $35.54 \mathrm{mbsf}$ ), with the maximum occurring at about $3.6 \mathrm{Ma}$ (35.8 mbsf). The W/C R (0.25) and the Dictyocha percentage values (16.4\%) in this interval would be tentatively indicative of SSSTs between $2.7^{\circ}$ and $4{ }^{\circ} \mathrm{C}$ above present levels. The silicoflagellate record at $3.5 \mathrm{Ma}$ (35.1 mbsf) (W/C R up to 0.10 and Dictyocha average abundance of $8.3 \%$ ), would suggest SSSTs of $2.5^{\circ} \mathrm{C}$ above modern level.

The radiograph facies and grain size distribution in the sediments recovered from Site 1165 are remarkably uniform throughout the studied interval (Fig. 4). The bioturbated mud, Facies 4, is the only facies observed and contains a relatively high percentage of sand (9\%) with a lower silt content with respect to the sites studied in the Antarctic Peninsula. Ice rafted debris pebbles are randomly sparse throughout the studied interval (both glacials and interglacials). Previous sedimentological studies on Site 1165 indicated a major textural change at 3.5 Ma with younger finer grained sediments sited above the studied interval (Passchier, 2007).

The biostratigraphic investigation allowed the identification of intervals of warm climatic conditions that cannot be univocally supported by evidence in the sediment facies, structures or composition (XRD or XRF) except for a higher concentration of IRD consisting on gravel and cm-thick pebbles (see correlation between the IRD distribution on the core log and the W/C R, Fig. 6).

\subsection{Early Pliocene glacial record: terrigenous supply and sedimentary} processes

\subsubsection{Antarctic Peninsula}

At Site 1095, intervals of increased terrigenous sediment supply are indicated by a positive correlation between peaks of $\mathrm{Al}, \mathrm{Ti}$, chlorite-kaolinite at 104.4-103.8 mbsf (3.7 Ma), 103, 100.6100.1 mbsf (3.6 Ma), and 99.4-97.8 mbsf (3.5 Ma) (Fig. 5). Our record shows that after $3.6 \mathrm{Ma} \mathrm{Al}$, Ti, and chlorite-kaolinite concentrations increased (Fig. 5). We interpret this increase as the start of an overall cooling trend beginning at 3.6 Ma. Terrigenous supply to Site 1096
(Fig. 5) is characterized by peaks in chlorite-kaolinite ( $406.2 \mathrm{mbsf}$ ), Ti and $\mathrm{Al}$ at $406.4 \mathrm{mbsf}$ and $405.2 \mathrm{mbsf}$.

Glacial sedimentation is characterized by laminated and structureless mud, and sediments with silt-patches (Facies 1, 2, 3). All sediment facies are characterized by a clay mineral assemblage dominated by chlorite-kaolinite with lower percentages of illite (25$30 \%$ ) and smectite (10-15\%) with respect to interglacials, indicating a predominance of down-slope gravity input of sediments (Fig. 5).

The laminated sediments (Facies 1 ) contain more coarse-grained silt, whereas the structureless mud (Facies 2) and the silty-patched mud (Facies 3 ) are dominated by fine-grained and medium-grained silt respectively. The lack of biogenic components in Facies 1, 2, and 3 indicate reduced productivity from unfavourable environmental conditions and/or dissolution of biogenic particles (e.g. presence of few and fragmented diatoms badly preserved). The absence of clearly evident bioturbation in Facies 2 and the presence of undisturbed laterally continuous laminations in Facies 1 confirm reduced benthos activity with lamination produced by either contour currents or gravity driven flows generating shear stress at the sea bottom.

Structureless and laminated muds were previously described on the late Quaternary sedimentary sequence and were interpreted to represent glacial and/or transitional climatic conditions (Pudsey and Camerlenghi, 1998; Pudsey, 2000; Lucchi et al., 2002; Lucchi and Rebesco, 2007). Accordingly, we ascribe Facies 1 to full glacial conditions and Facies 2 to less severe cold conditions (Site 1096), in which the lack of lamination indicates little or no shear stress at the seabottom (either weak bottom currents or little influence by gravity flows due to the more elevated site over the channel system).

Mud with silty patches (Facies 3 ) observed in sediments from Site 1095 alternates with the bioturbated mud (Facies 4, interglacial facies). We suggest that Facies 3 was also deposited during minor cold climatic conditions under the influence of both gravity and contour currents. A similar sediment facies was described for silty/muddy contourites in which silt patches (mottles) are produced by bioturbation of the silt fraction (Stow et al., 2002; Stow and Faugères, 2008). We suggest a combination of contour currents generating the silt patches and turbidity currents that delivered sediments with a high chlorite content. The absence of Facies 3 at Site 1096 may be related to a minor influence of bottom-contour and turbidity currents on the sedimentation at this site, because of its more elevated location on Drift 7 (Fig. 1). Lucchi et al. (2002) reported reduced clay mineral values of both contour current-driven smectite during interglacials and turbidity flow-driven chlorite during glacials at the summit of Drift 7.

\subsubsection{Prydz Bay}

Enhanced terrigenous sediment supply to Site 1165 is indicated by higher $\mathrm{Al}, \mathrm{Ti}$, and illite contents and low values of biogenic $\mathrm{Ba}$ and $F$. barronii at $38.45 \mathrm{mbsf}$ (3.8 Ma), 37 and $35.8 \mathrm{mbsf}$ (3.6 Ma), and 35.3 and $34.85 \mathrm{mbsf}$ (3.5 Ma). An increase of $\mathrm{Ti}, \mathrm{Fe}, \mathrm{Al}$ and $\mathrm{K}$ concentrations similar to that observed at Site 1095 starts at 3.7 Ma. The biostratigraphic and geochemical investigation allows the identification of intervals of colder climatic conditions. The glacial intervals are not univocally supported by sediment structures or composition, because sediment facies and grain size distribution is remarkably uniform throughout the studied interval (Fig. 4). The sandy bioturbated mud with randomly sparse IRD (Facies 4 ) at Site 1165, may indicate more stable current conditions, in which sediment delivery to the slope and rise mainly resulted from IRD supply.

\subsection{The circum-Antarctic record of warm and cold Pliocene events}

We correlated the ages assigned to the sections of Sites 1095, 1096 and 1165 with the Marine Isotopic Stages of standard oxygen isotope curve proposed by Lisiecki and Raymo (2005) (Fig. 7). Correlations 
show interpreted warm events in the Antarctic sites coinciding with interglacial stages in the isotopic records (Fig. 7). Using our age model, periods of warmth are recorded in both the Antarctic Peninsula and Prydz Bay regions, which correlate with isotopic stages Gi5, Gi1, MG11, and MG7 (Fig. 7). This finding suggests a coeval response to warming of both the APIS and the EAIS. The circum-Antarctic event corresponding to isotopic stage MG11 coincides with the section dated by the magnetic polarity reversal (Gilbert-Gauss) at $3.58 \mathrm{Ma}$ (Fig. 3). MG11 also coincides with the interval when the silicoflagellate warm/cold index at Site 1165 indicates tentative SSSTs $2.7^{\circ}-$ $4{ }^{\circ} \mathrm{C}$ above present level. Based in our age model and calculated sedimentation rates glacial-interglacial cyclicity between 3.7 and 3.5 Ma in the cores from Antarctic Peninsula and Prydz Bay Sites, result in average frequencies between 40 and $10 \mathrm{kyr}$ consistent with obliquity and precession forcing.

We observe that isotopic stage Gi5 is one of the warmest and longest lasting interglacials within the studied time interval. During this interglacial SSST data from Site 1165 indicates open water conditions in the absence of sea-ice. SSST during this interval, as suggested by the silicoflagellate warm/cold ratio was $>5.6{ }^{\circ} \mathrm{C}$ above present. Similarly, isotopic stages MG11 and MG7 occur during a prolonged period of warmth characterized by low-amplitudes in glacial-interglacial cyclicity (Fig. 7). Our records indicate that these intervals were characterized by warmer surface waters and less seaice. This is supported by 1 ) our interpretation of the abundance of $F$. barronii and the lack of sea-ice related taxa; 2) enhanced biogenic opal concentrations (average $14 \mathrm{wt} . \%$ in the Antarctic Peninsula and 27.5 wt.\% in Prydz Bay) compared to late Quaternary concentrations (average 8 wt.\%) (cf. Hillenbrand and Fütterer, 2002; Hepp et al., 2006); and 3) the silicoflagellate W/C R from Site 1165 (Fig. 6). In addition, the retreat of ice sheets during this interval of prolonged warmth is suggested by the bioturbated and IRD-enriched facies that characterize these high-productivity intervals. For previous warm periods, other studies suggest that the warm conditions result from strengthened Northern Component Water (NCW) influx into the Southern Ocean and increased heat input and upwelling of CDW close to the shelf break. This causes warmer surface water conditions south of the APF (e.g., Hillenbrand and Fütterer, 2002; Grützner et al., 2005; Hepp et al., 2006).

An increase of the terrigenous sediment supply at all our sites starting between 3.7 and 3.6 Ma suggest that this prolonged warm period was superimposed on a cooling trend. A cooling trend is also supported by the onset of global sea level drop at 3.6 Ma (Haq et al., 1987; Krantz, 1991) (Fig. 7). We postulate that, although the start of a cooling trend is recorded at about 3.7-3.6-Ma at our sites, relatively warm conditions prevailed until 3.6-3.5 Ma and maintained open marine conditions with reduced or no sea-ice and reduced ice sheet volume and extent. The start of the cooling trend coincided with a decrease in SSST as indicated by the silicoflagellate W/C R from Site 1165 , which indicates an overall decrease from $5.7^{\circ} \mathrm{C}$ at $3.7 \mathrm{Ma}$ to $4^{\circ}-$ $2.7^{\circ} \mathrm{C}$ at $3.6 \mathrm{Ma}$, and $2.5^{\circ} \mathrm{C}$ at $3.5 \mathrm{Ma}$.

Coeval glacial events based on our age model are recorded at the Antarctic Peninsula and in Prydz Bay between the warm intervals. In contrast to the late Quaternary sequence, in the late Pliocene drift sediments from the Antarctic Peninsula rise, the transition from interglacial to glacial conditions appears to be abrupt with IRD-rich sediments truncated by the onset of laminated sediments (Fig. 4). Hepp et al. (2006) describe the same type of transition for older early Pliocene sediments. Although we see evidence in our records for ice sheet reduction, we agree with the conclusion of Hepp et al. (2006) and Smellie et al. (2009) that the APIS did not fully collapse during the interglacial intervals, which allowed a rapid onset of the glacial downslope gravity transport processes during colder conditions. This conclusion is consistent with the interglacial clay mineral assemblage that is dominated by illite ( $>30 \%$ ) delivered to the continental slope and rise through sub-glacial meltwater plumes at the glacial terminus (see Section 5.2.1). A fully retreated ice-sheet would have prevented the water plumes to reach the slope and rise and the sediments would have been trapped on the shelf (similar to today).

A highly dynamic glacial regime during the early Pliocene is shown by pronounced variability in the down-core distribution of sediment parameters and sedimentary facies, which is better recorded on the Antarctic Peninsula margin than in Prydz Bay. This variability may result from differences in sediment delivery by the ice sheets on the two margins. The Antarctic Peninsula sites may record a more dynamic behavior of the APIS (i.e., faster response of the ice sheet to cooling and warming). We attribute the uniform down-core pattern of proxies and facies at Site 1165 to a slower response of the terrestrial EAIS to climate change.

\section{Conclusions}

Our study shows that the application of uniform methodologies to the high-resolution study of multiple proxies from the same core intervals can yield a record of changes in primary biogenic productivity (siliceous microfossils, biogenic opal, biogenic Ba), terrigenous supply (e.g., Al, Ti), and sedimentary processes (sedimentary facies, textures and clay mineralogy) that can be combined to interpret a robust history of glacial-interglacial cyclicity.

Four circum-Antarctic warm events/intervals are recorded in the studied Pliocene section. Warm conditions in both East and West Antarctica are recorded, which based in our age model correspond to isotopic stages Gi5, Gi1, MG11 and MG7. Our records indicate these are periods of prolonged or extreme warmth. For the Gi5 interglacial our data corroborates the $60 \%$ Dictyocha percentage at $34.60 \mathrm{mbsf}$ reported by Whitehead and Bohaty (2003) interpreted to indicate a SSST of about $5.6{ }^{\circ} \mathrm{C}$ above present. Our higher-resolution sampling interval shows Dictyocha percentages up to $87.5 \%$, which indicates SSST $>5.6{ }^{\circ} \mathrm{C}$ above present levels. During MG11, which coincides with the section dated by the magnetic polarity reversal Gilbert-Gauss at 3.58 Ma, SSSTs were $2.5^{\circ}-4^{\circ}$ warmer than present and reduced seaice cover in Prydz Bay and probably also west of the Antarctic Peninsula, is indicated by increased primary productivity. In addition, a reduction of ice sheet size is suggested by the bioturbated and IRDenriched facies that characterizes these high-productivity intervals. Based in our age model and calculated sedimentation rates glacialinterglacial cyclicity between 3.7 and $3.5 \mathrm{Ma}$ in the cores from Antarctic Peninsula and Prydz Bay Sites, result in average frequencies at the obliquity and precession forcing.

An increase of the terrigenous sediment supply at all our sites starting between 3.7-3.6 Ma suggest that this prolonged warm period was superimposed on a cooling trend also recorded by the decrease in SSSTs (from $>5.6{ }^{\circ} \mathrm{C}$ at $3.7 \mathrm{Ma}$ to $4^{\circ}-2.7^{\circ} \mathrm{C}$ at $3.6 \mathrm{Ma}$, and $2.5^{\circ} \mathrm{C}$ at 3.5 Ma.) indicated by the silicoflagellate $\mathrm{W} / \mathrm{C}$ R from Site 1165 . We postulate that, although the start of a cooling trend is recorded at about 3.7-3.6-Ma at our sites, relatively warm conditions prevailed until 3.6-3.5 Ma and maintained open marine conditions with reduced or no sea-ice and reduced ice sheet volume and extent.

These results from two regions of the Southern Ocean, when combined with new information from the ANDRILL AND-1B drillcore in the western Ross Sea (Naish et al., 2009), provide a continent-wide perspective on Pliocene ice sheet behavior in response to climate changes. These data, when linked to modeling studies like those of Pollard and DeConto (2009) will further our understanding of how these ice sheets may respond to future warming of the southern high latitudes. Future studies from the marine realm, integrated with onland studies such as those from the Pagodroma and Sirius Group, (Harwood, 1983; Harwood and Webb, 1986, 1991; Webb et al., 1996; Francis and Hill, 1996), will be required to understand the level and the duration of early-middle Pliocene warming and its impact on the EAIS. 


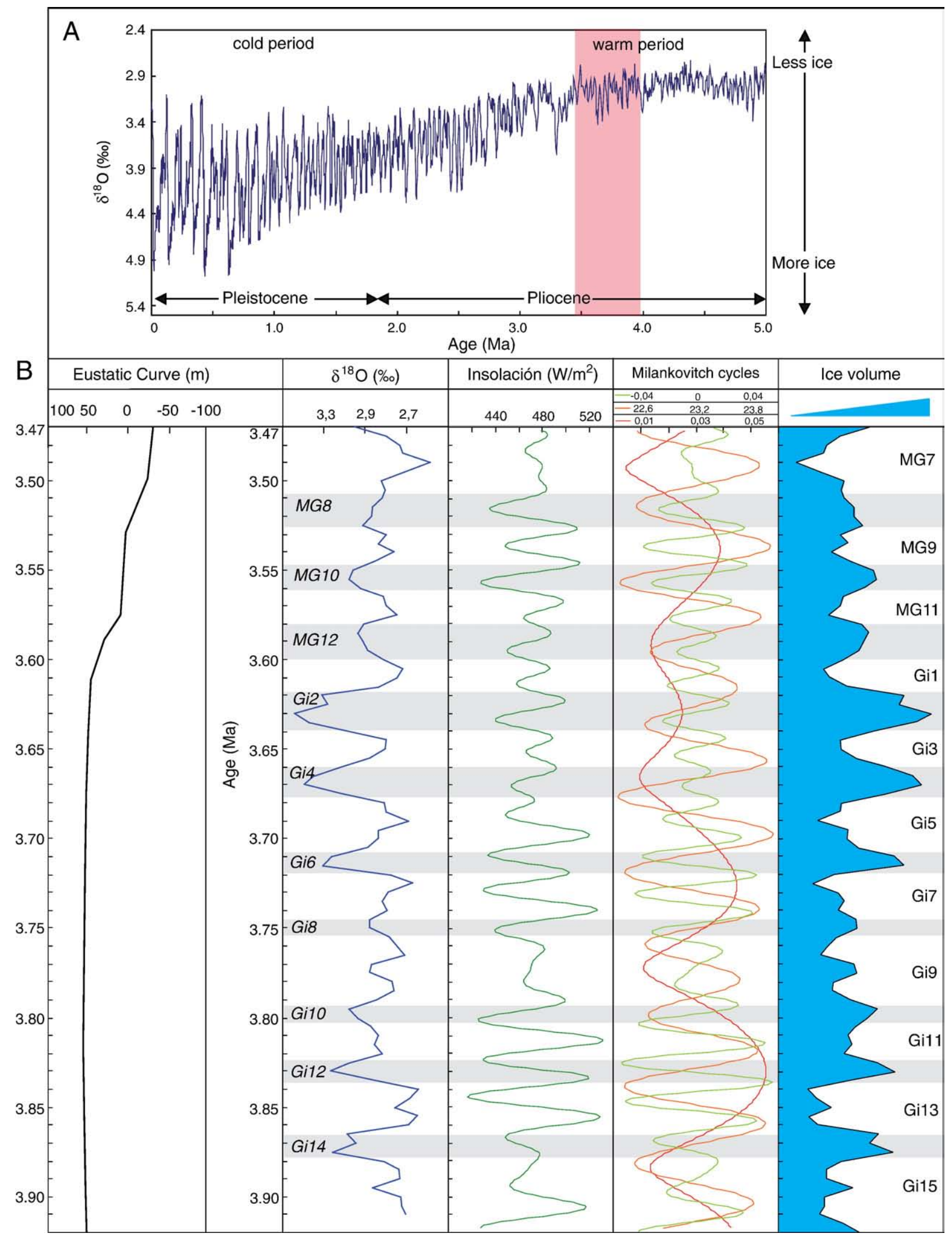

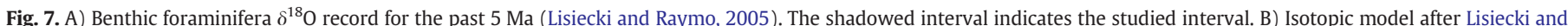

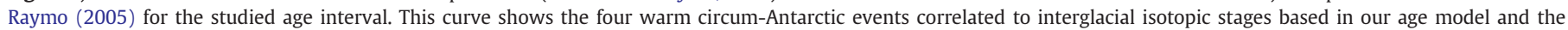

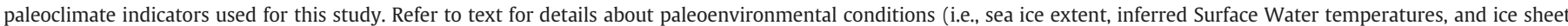

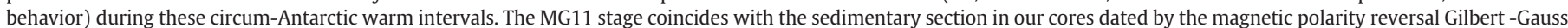
at $3.58 \mathrm{Ma}$. 


\section{Acknowledgements}

The authors want to thank the Integrated Ocean Drilling Program for providing the samples used in this study. We thank Walter Hale and the staff at the IODP Bremen Core Repository for all their help prior to and during the sampling party, and Tobias Moerz and Daniel Hepp for providing the X-Ray images of selected intervals. We thank Hans Nelson for reviewing a preliminary draft of this paper and ClausDieter Hillenbrand and Sandra Passchier for their valuable review comments, which greatly improved this manuscript. The research in this paper has been supported by the Spanish Ministry of Science and Education Grants: REN2003-0922-CO2-01 and POL2006-072667/CGL. Additional support received by Grant CSD2007-00067.

\section{References}

Barker, P.F., Camerlenghi, A., Acton, G.D., et al., 1999. Proceedings of the Ocean Drilling Program: Initial Reports, vol. 178 (CD-ROM). Available from: Ocean Drilling Program, Texas A\&M University, College Station, TX 77845-9547, U.S.A.

Barker, P.F., Camerlenghi, A., Acton, G.D., Ramsay, A.T.S. (Eds.), 2002. Proceedings of the Ocean Drilling Program: Scientific Results, vol. 178 (CD-ROM). Available from: Ocean Drilling Program, Texas A\&M University, College Station, TX 77845-9547, U.S.A.

Berggren, W.A., Kent, D.V., Swisher, C.C., Aubry, M.P. 1995, A revised Cenozoic geochronology and chronostratigraphy. In: B.W.A., Kent, D.V., Aubry, M.P., Hardenbol, J. (Eds.), Geochronology, time scales and global stratigraphic correlation: Spec. Publ.SEPM (Soc. Sediment. Geol.), pp. 129-212.

Biscaye, P.E., 1965. Mineralogy and sedimentation of recent deep-sea clay in the Atlantic Ocean and adjacent areas and oceans. Geol. Soc. Am. Bull. 76, 803-832.

Bohaty, S.M., Harwood, D.M., 1998. Southern Ocean Pliocene paleotemperature variation from high-resolution silicoflagellate biostratigraphy. Marine Micropaleontology 33, 241-272.

Cande, S.C., Kent, D.V., 1995. Revised calibration of the geomagnetic polarity timescale for the Late Cretaceous and Cenozoic. Journal of Geophysical Research 100,6093-6095.

Cortese, G., Gersonde, R., 2008. Plio/Pleistocene changes in the main biogenic silica carrier in the Southern Ocean, Atlantic sector. Marine Geology 25, 100-110.

Crosta, X., Pichon, J.J., Romero, O., Armand, L.K., 2005. The biogeography of major diatom taxa in Southern Ocean sediments: 2. Open ocean related species. Palaeogeography, Palaeoclimatology, Palaeoecology 223 (1), 66-92.

De Master, D.J., 1981. The supply and accumulation of silica in the marine environment. Geochimica Cosmochimica Acta 45, 1715-1732.

Dowsett, H., Barron, J., Poore, R.Z., 1996. Middle Pliocene sea surface temperatures: global reconstruction. Marine Micropaleontology 27, 13-25.

Ehrmann, W., Bloemendal, J., Hambrey, M., McKelvey, B., Whitehead, J., 2003. Variations in the composition of the clay fraction of the Cenozoic Pagodroma Group, East Antarctica: implications for determining provenance. Sedimentary Geology 161 (1-2), 131-152

Francis, J.E., Hill, R.S., 1996. Fossil plants from the Pliocene Sirius Group, Transantarctic Mountains: evidence for climate from growth rings and fossil leaves. Palaios 11 389-396.

Freedman, G.M., Sanders, J.E., 1978. Principles of Sedimentology. John Wiley and Sons, NewYork, 792 pp.

Gordon, A., Molinelli, E., 1982. Southern Ocean Atlas: thermohaline and chemica distributions. Columbia University Press, NY.

Grützner, J., Hillenbrand, C.-D., Rebesco, M., 2005. Terrigenous flux and biogenic silica deposition at the Antarctic continental rise during the late Miocene to early Pliocene: implications for ice sheet stability and sea ice coverage. Global and Planetary Change 45, 131-149.

Hambrey, M.J., Ehrmann, W.U., Larsen, B., 1991. Cenozoic glacial record of the Prydz Bay continental shelf, East Antarctica. In: Barron, J., Larsen, B., et al. (Eds.), Proceedings of the Ocean Drilling Program. Scientific Results, vol. 119. Ocean Drilling Program, College Station, TX, pp. 77-132.

Haq, B.U., Hardenbol, J., Vail, P.R., 1987. Chronology of fluctuating sea levels since the Triassic. Science 235, 1156-1167.

Harwood, D.M., 1983. Diatoms from the Sirius Formation, Transantarctic Mountains Antarctic Journal of the United States 18 (5), 98-100.

Harwood, D.M., Webb, P.N., 1986. Recycled siliceous microfossils from the Sirius Formation. Antarctic Journal of the United States 21 (5), 101-103.

Harwood, D.M., Webb, P.N., 1991. Early interpretations of Antarctic and Arctic glacia history: uniformitarian biases mask a dynamic history of Cenozoic ice-volume variation. Geological Society of America Abstracts with Programs 25 (5), 106.

Harwood, D.M., McMinn, A., Quilty, P., 2000. Diatom ages of Sorsdal Formation, Vestfold Hills, Antarctica. Antarctic Science 14 (4), 443-462.

Haywood, A.M., Valdes, P.J., Sellwood, B.W., 2000. Global scale palaeoclimate reconstruction of the middle Pliocene climate using the UKMO GCM: initial results. Global and Planetary Change 25 (3/4), 239-256.

Haywood, A.M., Smellie, J.L., Ashworth, A.C., Cantrill, J., Florindo, F., Hambrey, M. J., Hill, D., Hillenbrand, C.D., Hunter, S.J., Larter, R.D., Lear, C.H., Passchier, S., van de Wal, R., 2009. Middle Miocene to Pliocene history of Antarctica and the Southern Ocean. In: Florindo, F., Siegert, M. (Eds.), Antarctic Climate Evolution: Developments in Earth and Environmental Sciences, vol. 8, pp. 401-464.
Hepp, D.A., Moerz, T., Grutzner, J., 2006. Pliocene glacial cyclicity in a deep-sea sediment drift (Antarctic Peninsula Pacific Margin). Palaeogeography, Palaeoclimatology, Palaeoecology 231, 181-198.

Hillenbrand, C.-D., Ehrmann, W., 2001. Distribution of clay minerals in drift sediments on the continental rise west of the Antarctic Peninsula, ODP Leg 178, Sites 1095 and 1096. In: Barker, P.F., Camerlenghi, A., Acton, G.D., Ramsay, A.T.S. (Eds.), Proc. ODP, Sci. Results, vol. 178, pp. 1-29 ((CD-ROM). Available from: Ocean Drilling Program, Texas A\&M University, College Station TX 77845-9547, U.S.A.).

Hillenbrand, C.D., Ehrmann, W., 2005. Late Neogene to Quaternary environmental changes in the Antarctic Peninsula region: evidence from drift sediments. Global and Planetary Change 45, 165-191.

Hillenbrand, C.-D., Fütterer, D.K., 2002. Neogene to Quaternary deposition of opal on the continental rise west of the Antarctic Peninsula, ODP Leg 178, Sites 1095, 1096 and 1101. In: Barker, P.F., Camerlenghi, A., Acton, G.D., Ramsay, A.T.S. (Eds.), Proc. ODP Sci. Results, vol. 178, pp. 1-33 (CD-ROM). Available from: Ocean Drilling Program, Texas A\&M University, College Station TX 77845-9547, U.S.A.

Hillenbrand, C.-D., Camerlenghi, A., Cowan, E.A., Hernández-Molina, F.J., Lucchi, R.G., Rebesco, M., Uenzelmann-Neben, G., 2008. The present and past bottom-current flow regime around the sediment drifts on the continental rise west of the Antarctic Peninsula. Marine Geology 255, 55-63.

Hodell, D.A., Venz, K., 1992. Toward a high-resolution stable isotopic record of the Southern Ocean during the Pliocene-Pleistocene (4.8 to $0.8 \mathrm{Ma}$ ). In: Kennett, J.D., Warnke, D.A. (Eds.), The Antarctic paleoenvironment: a perspective on global change. Antarct. Res. Ser., vol. 56. AGU, Washington, DC, pp. 265-310.

Hofmann, E.E., Klinck, J.M., Lascara, C.M., Smith, D.A., 1996. Water mass distribution and circulation west of the Antarctic Peninsula and including Bransfield Strait. In: Ross, R.M., Hofmann, E.E., Quetin, L.B. (Eds.), Foundations for Ecological Research West of the Antarctic Peninsula. Antarctic Research Series, vol. 70. AGU, Washington, DC, pp. $61-80$

Intergovernmental Panel on Climate Change (IPCC), report 2007: http://www.ipcc.ch/.

Iwai, M., Acton, G.D., Lazarus, D., Osterman, L.E., Williams, T., 2002. Magnetobiochronologic synthesis of ODP Leg 178 Rise Sediments from the Pacific sector of the Southern Ocean: Sites 1095, 1096 and 1101. In: Barker, P.F., Camerlenghi, A., Acton, G.D., Ramsay, A.T.S. (Eds.), Proceeding ODP, Scientific Results, College Station (TX), pp. 1-40.

Joseph, L.H., Rea, D.K., Van der Pluijm, B.A., Gleason, J.D., 2002. Antarctic environmental variability since the late Miocene: ODP Site 745, the East Kerguelen sediment drift. Earth and Planetary Science Letters 201, 127-142.

Juntilla, J., Ruikka, M., Strand, K., 2005. Clay-mineral assemblages in high-resolution Plio-Pleistocene interval at ODP Site 1165, Prydz Bay, Antarctica. Global and Planetary Change 45, 151-163.

Kennett, J.P., Hodell, D.A., 1995. Stability or instability of Antarctic ice sheets during warm climates of the Pliocene? GSA Today 5 (1), 9-22.

Kirsch, HJ. 1991. Illite crystallinity: recommendations on sample preparation, X-ray diffraction settings, and interlaboratory samples. J. Metamorph. Geol. 9, 665-670. Krantz, 1991. Quaternary Science Reviews 10, 163-174.

Lisiecki, L.E., Raymo, M.E., 2005. A Pliocene-Pleistocene stack of 57 globally distributed benthic d180 records. Paleoceanography 20, 1003.

Lourens, L.J., Antonarakou, A., Hilgen, F.J., Van Hoof, A.A.M., Vergnaud-Grazzini, C., Zacchariasse, W.J., 1996. Evaluation of the Plio-Pleistocene astronomical Timescale. Paleoceanography 11, 391-413.

Lucchi, R.G., Rebesco, M., 2007. Glacial contourites on the Antarctic Peninsula margin: insight for palaeoenvironmental and palaeoclimatic conditions. In: Viana, A.R., Rebesco, M., Editors, Economic and Palaeoceanographic Significance of Contourite Deposits, Geol. Soc. London Special Publ. 276, 111-127.

Lucchi, R.G., Rebesco, M., Camerlenghi, A., Busetti, M., Tomadin, L., Villa, G., Persico, D., Morigi, C., Bonci, M.C., Giorgetti, G., 2002. Mid-late Pleistocene glacimarine sedimentary processes of a high-latitude, deep-sea sediment drift (Antarctic Peninsula Pacific Margin). Marine Geology 189, 343-370.

Martin, J.D., 2004. Qualitative and quantitative powder X-ray diffraction analysis.

Müller, P., Schneider, R.R., 1993. An automated leaching method for the determination of opal in sediments and particulate matter. Deep-Sea Research I 40, 425-444.

Naish, T., Powell, R., Levy, R., Krissek, L, Niessen, F., Pompilio, M., Scherer, R., Talarico, F., Wilson, G., Wilson, T., Browne, G., Carter, C., Cody, R., Cowan, C., Crampton, J., Dunbar, G., Dunbar, N., Florindo, F., Gebhardt, C., Graham, I, Hannah, M., Harwood, D., Hansaraj, D., Henrys, S., Helling, D., Kuhn, G., Kyle, P., Läufer, A., Maffioli, P., Magens, D., Mandernack, K., McIntosh, W., McKay, R., Millan, C., Morin, R., Ohneiser, C., Paulsen, T., Persico, D., Reed, J., Ross, J., Raine, I., Schmitt, D., Sagnotti, L., Sjunneskog, C., Strong, P., Taviani, M., Vogel, S., Wilch, T., Williams, T., Winter, D., 2009. Late Cenozoic stability of the West Antarctic Ice Sheet. Nature 458, 322-328. doi:10.1038/nature07867. 19 March 2009.

Nunes, R.A., Lennon, G.W., 1996. Physical oceanography of the Prydz Bay region of Antarctic waters. Deep-Sea Research I 43 (5), 603-641.

O'Brien, P.E., Cooper, A.K., Richter, C., et al., 2001. Proc. ODP, Init. Repts. 188 [Online]. Available from World Wide Web: http://www-odp.tamu.edu/publications/188_IR/ 188ir.htm.

O'Brien, P.E., Cooper, A.K., Florindo, F., Handwerger, D., Lavelle, M., Passchier, S., Pospichal, J.J., Quilty, P.G., Richter, C., Theissen, K.M., Whitehead, J.M., 2004. Prydz channel fan and the history of extreme ice advances in Prydz Bay. In: Cooper, A.K., O'Brien, P.E., Richter, C. (Eds.), Proc. ODP, Sci. Results, vol. 188. [Online]. Available from World Wide Web: $<$ http://www-odp.tamu.edu/publications/188_SR/016/016>

Orsi, A.H., Whitworth III, T., Nowlin Jr., W.D., 1995. On the meridional extent and fronts of the Antarctic Circumpolar current. Deep-Sea Research I 42 (5), 641-673.

Passchier, S., 2007. Antarctic ice-sheet dynamics between 5.2 and 0 Ma from a highresolution terrigenous particle size record, ODP Site 1165, Prydz Bay-Cooperation Sea. U.S. Geological Survey and The National Academies; USGS OF-2007-1047, Short Research Paper 043. doi:10.3133/of2007-1047.srp043. 
Passchier, S., O'Brien, P.E., Damuth, J.E., Januszczack, N., Handwerger, D.A., Whitehead, J.M 2003. Pliocene-Pleistocene glaciomarine sedimentation in eastern Prydz Bay and development of the Prydz trough-mouth fan, ODP Sites 1166 and 1167, East Antarctica. Marine Geology 199, 179-305.

Patterson, S.L., Whitworth III, T., 1990. Physical Oceanography. In: Glasby, G.P. (Ed.), Antarctic Sector of the Pacific. Elsevier Oceanographic Series, vol. 51. Elsevier, Amsterdam, pp. 55-93.

Pickard, J., Adamson, D.A., Harwood, D.M., Miller, G.H., Quilty, P.G., Dell, R.G., 1988. Early Pliocene marine sediments, coastline, and climate of East Antarctica. Geology 16, $158-161$.

Pollard, D., DeConto, R.M., 2009. Modelling West Antarctic ice sheet growth and collapse through the past five million years. Nature 458, 329-332. doi:10.1038/ nature07867. 19 March 2009.

Pudsey, C.J., 2000. Sedimentation on the continental rise west of the Antarctic Peninsula over the last three glacial cycles. Marine Geology 167, 313-338.

Pudsey, C.J., Camerlenghi, A., 1998. Glacial-interglacial deposition on a sediment drift on the Pacific margin of the Antarctic Peninsula. Antarct. Sci. 10, 286-308.

Raymo, M.E., Grant, B., Horowitz, M., Rau, G.H., 1996. Mid-Pliocene warmth: stronger greenhouse and stronger conveyor. Marine Micropaleontology 27, 313-326.

Rebesco, M., Larter, R.D., Barker, P.F., Camerlenghi, A., Vanneste, L.E., 1997. The history of sedimentation on the continental rise west of the Antarctic Peninsula. In: Barker, P.F., Cooper, A.K. (Eds.), Geology and Seismic Stratigraphy of the Antarctic Margin, Part 2. : Antarctic Research Series, vol. 71. AGU, Washington DC, pp. 29-49.

Rebesco, M., Camerlenghi, A., Volpi, V., Neagu, C., Accettella, D., Lindberg, B., Cova, A., Zgur, F., and the MAGICO Party, 2007. Interaction of processes and importance of contourites: insights from the detailed morphology of sediment drift 7, Antarctica. In: Viana, A.R., Rebesco, M. (Eds.), Marine Economic and Palaeoceanographic Significance of Contourite Deposits. Geol. Soc. London Special Publications 276, 95-110.

Schrader, H.-J., Gersonde, R., 1978. Diatoms and silicoflagellates. In: Zachariasse, W.J., et al. (Ed.), Micropaleontological counting methods and techniques - an exercise on an eight meter section of the Lower Pliocene of Capo Rosello, Sicily: Utrecht Micropaleontological Bulletin, pp. 129-176.

Shackleton, N.J., Crowhurst, S.J., Hagelberg, T., Pisias, N.G., Schneider, D.A., 1995. A new late Neogene time scale: application to Leg 138 sites. In: Pisias, N.G., Mayer, L.A., Janecek, T.R., Palmer-Julson, A., van Andel, T.H. (Eds.), Proceedings of the Ocean Drilling Program. Scientific Results, vol. 138. Ocean Drilling Program, College Station, TX.

Skene, K.I., Piper, D.J.W., 2003. Late Quaternary stratigraphy of the Laurentian Fan: a record of events off the eastern Canadian continental margin during the last deglacial period. Quaternary International 99-100, 135-152.

Sloan, L.C., Crowley, T.J., Pollard, D., 1996. Modeling of middle Pliocene climate with the NCAR GENESIS general circulation model. Marine Micropaleontology 27 (1/4), 51-61.
Smellie, et al., 2009. Earth Science Reviews 94, 74-94.

Smith, N.R., Zhaoqian, D.J., Kerry, K.R., Wright, S., 1984. Water masses and circulation in the region of Prydz Bay, Antarctica. Deep-Sea Research Part A 31, 1121-1147.

Smith, D.A., Hofmann, E.E., Klinck, J.M., Lascara, C.M., 1999. Hydrography and circulation of the West Antarctic Peninsula Continental Shelf. Deep-Sea Research I 46, 925-949.

Stow, D.A.V., Faugères, J.C., 2008. Contourite facies and facies model. In: Rebesco, M., Camerlenghi, C. (Eds.), Contourites: Development in Sedimentology, vol. 60, pp. 223-250.

Stow, D.A.V., Faugères, J.C., Gonthier, E., Cremer, M., Llave, E., Hernandez-Molina, F.J., Somoza, L., Diaz-Del-Rio, V., 2002. Faro-Albufeira drift complex, northern Gulf of Cadiz. In: Stow, D.A.V., Pudsey, C.J., Howe, J.A., Faugères, J.C., Viana, A.R. (Eds.), Deep-water contourite systems: modern drifts and ancient series, seismic and sedimentary characteristics: Geol. Soc. London Mem., vol. 22, pp. 137-154.

Warnke, D.A., Richter, C., Florindo, F., Damuth, J.E., Balsam, W.L., Strand, K., Ruikka, M. Juntilla, J., Theissen, K., Quilty, P., 2004. Data Report: HiRISC (High-Resolution Integrated Stratigraphy Commitee) Pliocene-Pleistocene interval, 0-50 mbsf at ODP Leg 188 site 1165, Bahia de Prydz, Antarctica. In: Cooper, A.K., O'Brien, P.E., Richter, C. (Eds.), Proc. ODP Scientific Results, pp. 1-38.

Webb, P.-N., Harwood, D.M., 1991. Late Cenozoic glacial history of the Ross Embayment, Antarctica. Quaternary Science Reviews 10, 215-223.

Webb, P.-N., Harwood, D.M., Mabin, M.G.C. McKelvey, B.C, 1996. A marine and terrestrial Sirius Group succession, middle Beardmore Glacier-Queen Alexandra Range, Transantarctic Mountains, Antarctica. Marine Micropaleontology 27 (1/4) 273-297.

Whitehead, J.M., Bohaty, S.M., 2003. Pliocene summer sea-surface temperature reconstruction using silicoflagellates from Southern Ocean ODP Site 1165. Paleoceanography 18, 1075-1086.

Whitehead, J.M., Quilty, P., Harwood, D.M., McMinn, A, 2001. Diatom palaeoenvironment of the Sorsdal Formation, Vestfold Hills based on diatom data. Marine Micropaleontology 41, 125-152.

Whitehead, J.M., Wotherspoon, S., Bohaty, S.M., 2005. Minimal Antarctic sea ice during the Pliocene. Geology 33, 137-140.

Zachos, J., Pagani, M., Sloan, L., Thomas, E., Billups, K., 2001. Trends, rhythms, and aberrations in global climate 65 Ma to present. Science 292, 686-693.

Zielinski, U., Gersonde, R., 1998. Quaternary surface water temperature estimations: calibration of a diatom transfer function for the Southern Ocean. Paleoceanography 12 (4), 365-383.

Zielinski, U., Gersonde, R., 2002. Plio/Pleistocene diatom biostratigraphy from ODP Leg 177, Atlantic sector of the Southern Ocean. Marine Micropaleontology 45, 225-268. 